\title{
Vegetation, climate and environmental dynamics of the Black Sea/Northern Anatolian region during the last 134 ka obtained from palynological analysis
}

\author{
Dissertation \\ zur Erlangung des mathematisch-naturwissenschaftlichen Doktorgrades \\ "Doctor rerum naturalium" \\ der Georg-August-Universität Göttingen \\ im Promotionsprogramm Biologie \\ der Georg-August University School of Science (GAUSS)
}

\author{
vorgelegt von \\ Lyudmila Shumilovskikh \\ aus Kukushtan, Permskaya oblast', Russland
}

Göttingen, 2013 



\section{Betreuungsausschuss}

Prof. Dr. Hermann Behling, Abteilung Palynologie und Klimadynamik, Albrecht-von-Haller Institut für Pflanzenwissenschaften, Georg-August-Universität Göttingen

Prof. Dr. Erwin Bergmeier, Abteilung Vegetationsanalyse und Phytodiversität, Albrecht-vonHaller Institut für Pflanzenwissenschaften, Georg-August-Universität Göttingen

\section{Mitglieder der Prüfungskommission}

\section{$\underline{\text { Referent }}$}

Prof. Dr. Hermann Behling, Abteilung Palynologie und Klimadynamik, Albrecht-von-Haller Institut für Pflanzenwissenschaften, Georg-August-Universität Göttingen

$\underline{\text { Korreferent }}$

Prof. Dr. Erwin Bergmeier, Abteilung Vegetationsanalyse und Phytodiversität, Albrecht-vonHaller Institut für Pflanzenwissenschaften, Georg-August-Universität Göttingen

$\underline{\text { Weitere Mitglieder der Prüfungskommission }}$

PD Dr. Dirk Gansert, Abteilung Pflanzenökologie und Ökosystemforschung, Albrecht-vonHaller Institut für Pflanzenwissenschaften, Georg-August-Universität Göttingen

Prof. Dr. Hans Ruppert, Abteilung Sedimentologie und Umweltgeologie, Geowissenschaftliches Zentrum, Georg-August-Universität Göttingen

Prof. Dr. Edzo Veldkamp, Abteilung Ökopedologie der Tropen und Subtropen, BüsgenInstitut, Georg-August-Universität Göttingen

Prof. Dr. Kerstin Wiegand, Abteilung Ökosystemmodellierung, Büsgen-Institut, GeorgAugust-Universität Göttingen

\section{Tag der mündlichen Prüfung}

06.03.2013 

Моей любимой семье 


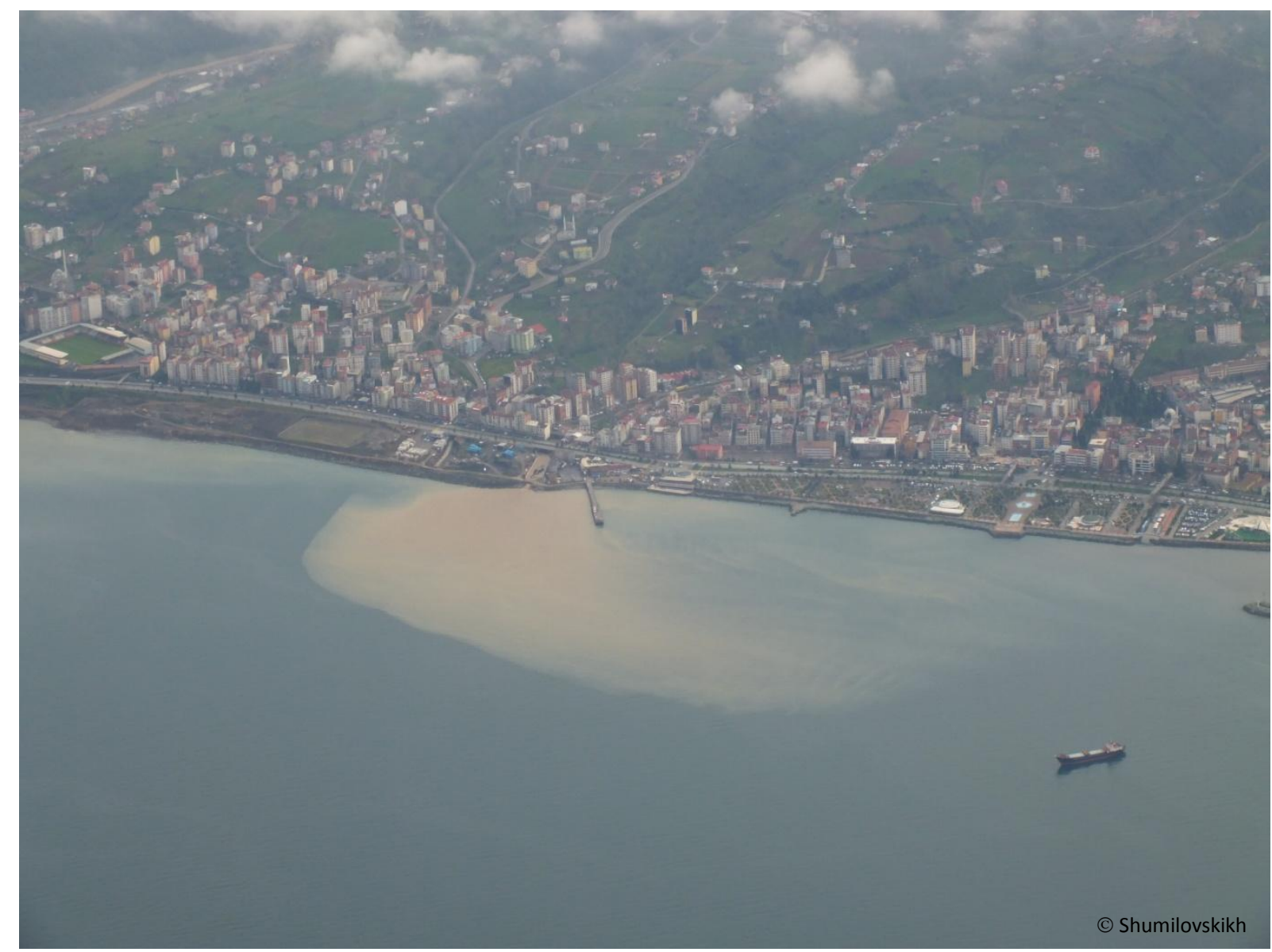

View of the Black Sea coast near Trabzon, showing sediment transport from land to sea 


\section{TABLE OF CONTENTS}

1. Background 2

2. Previous palaeostudies from the Black Sea and surrounding regions 4

2.1. Pleistocene evolution of the Black Sea basin 4

2.2. Pollen records from the Black Sea and surrounding regions 6

2.3. Dinoflagellate cyst records from the Black Sea...................................................... 10

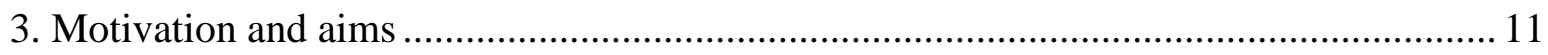

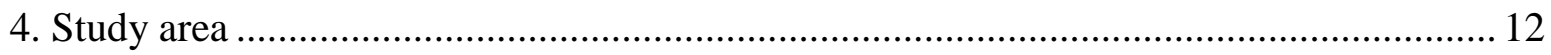

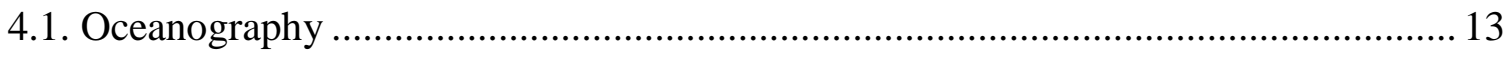

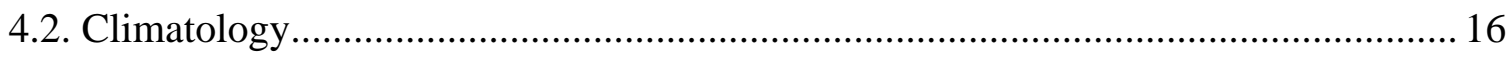

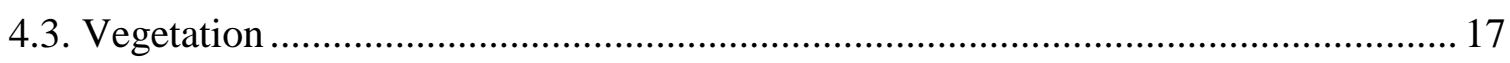

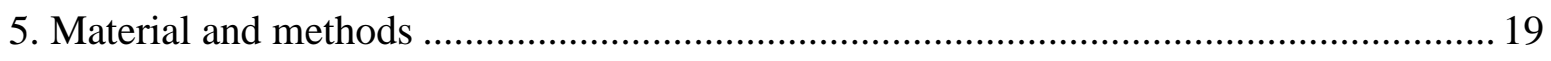

5.1. Pollen, spores and non-pollen palynomorph analysis .......................................... 19

5.2. Organic-walled dinoflagellate cyst analysis ..................................................... 20

6. Outline of manuscripts and description of personal contribution................................. 21

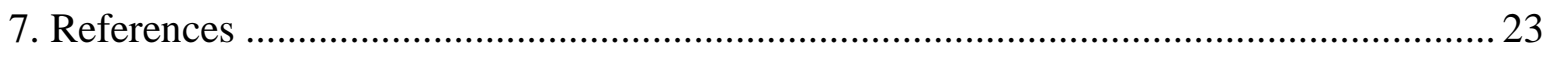

MANUSCRIPT 1 38

Vegetation and environmental dynamics in the southern Black Sea region since 18 kyr BP derived from the marine core 22-GC3

(L.S. Shumilovskikh, P. Tarasov, H.W. Arz, D. Fleitmann, F. Marret, N. Nowaczyk, B. Plessen, F. Schlütz, H. Behling)

MANUSCRIPT 2

Eemian and Holocene sea-surface conditions in the southern Black Sea: organic-walled dinoflagellate cyst record from core 22-GC3

(L.S. Shumilovskikh, F. Marret, D. Fleitmann, H.W. Arz, N. Nowaczyk, H. Behling)

MANUSCRIPT 3

Vegetation and environmental changes in Northern Anatolia between 134-119 ka recorded in Black Sea sediments

(L.S. Shumilovskikh, H.W. Arz, A. Wegwerth, D. Fleitmann, F. Marret, N. Nowaczyk, P.Tarasov, H. Behling) 
Millennial-scale environmental variability during the last glacial detected in pollen and dinocyst records from the SE Black Sea (L.S. Shumilovskikh, H. Arz, N. Nowaczyk, D. Fleitmann, A. Wegwerth, H. Behling)

MANUSCRIPT 5 164

Recent pollen distribution in Northern Anatolia and the SE Black Sea: preliminary results

(L.S. Shumilovskikh, F. Schlütz, H. Behling)

SYNTHESIS

PERSPECTIVES

APPENDIX 1.

Complete pollen diagram (\%) of the upper part of the core 22-GC3, covering the last $18 \mathrm{ka}$

APPENDIX 2......

Complete pollen diagram (\%) of the cores 22-GC3/8, covering the penultimate deglaciation and the Eemian during 134-119 ka BP

APPENDIX 3.

Complete pollen diagram (\%) of the core 25-GC1, covering the last glacial period during 64-25 ka BP

APPENDIX 4.

Complete pollen diagram (\%) for surface samples, collected in Northern Anatolia in 2011 


\section{TABLE OF CONTENTS}

ABSTRACT 1

$\begin{array}{ll}\text { INTRODUCTION } & 2\end{array}$

1. Background 2

2. Previous palaeostudies from the Black Sea and surrounding regions 4

2.1. Pleistocene evolution of the Black Sea basin 4

2.2. Pollen records from the Black Sea and surrounding regions 6

2.3. Dinoflagellate cyst records from the Black Sea 10

3. Motivation and aims 11

4. Study area $\quad 12$

4.1. Oceanography 13

4.2. Climatology 16

4.3. Vegetation 17

$\begin{array}{ll}\text { 5. Material and methods } & 19\end{array}$

5.1. Pollen, spores and non-pollen palynomorph analysis 19

5.2. Organic-walled dinoflagellate cyst analysis 20

6. Outline of manuscripts and description of personal contribution 21

7. References 23

$\begin{array}{ll}\text { MANUSCRIPT } 1 & 38\end{array}$

Vegetation and environmental dynamics in the southern Black Sea region since 18 kyr BP derived from the marine core 22-GC3

(L.S. Shumilovskikh, P. Tarasov, H.W. Arz, D. Fleitmann, F. Marret,

N. Nowaczyk, B. Plessen, F. Schlütz, H. Behling)

MANUSCRIPT 2

Eemian and Holocene sea-surface conditions in the southern Black Sea: organic-walled dinoflagellate cyst record from core 22-GC3

(L.S. Shumilovskikh, F. Marret, D. Fleitmann, H.W. Arz,

N. Nowaczyk, H. Behling)

MANUSCRIPT 3

Vegetation and environmental changes in Northern Anatolia between 134-119 ka recorded in Black Sea sediments

(L.S. Shumilovskikh, H.W. Arz, A. Wegwerth, D. Fleitmann, F. Marret, N.

Nowaczyk, P.Tarasov, H. Behling) 
Millennial-scale environmental variability during the last glacial detected in pollen and dinocyst records from the SE Black Sea (L.S. Shumilovskikh, H. Arz, N. Nowaczyk, D. Fleitmann,

A. Wegwerth, H. Behling)

MANUSCRIPT 5

Recent pollen distribution in Northern Anatolia and the SE Black Sea: preliminary results

(L.S. Shumilovskikh, F. Schlütz, H. Behling)

SYNTHESIS

PERSPECTIVES

Complete pollen diagram (\%) of the upper part of the core 22-GC3, covering the last $18 \mathrm{ka}$

\section{APPENDIX 2}

Complete pollen diagram (\%) of the cores $22-G C 3 / 8$, covering the penultimate deglaciation and the Eemian during 134-119 ka BP

\section{APPENDIX 3}

Complete pollen diagram (\%) of the core 25-GC1, covering the last glacial period during 64-25 ka BP

\section{APPENDIX 4}

Complete pollen diagram (\%) for surface samples, collected in Northern Anatolia in 2011 


\begin{abstract}
As a part of the multidisciplinary project "Dynamics of Mid-latitude/Mediterranean climate in Northern Anatolia/Black Sea region during the last 150 kyr”, this research presents new pollen and organic-walled dinoflagellate cyst records from the SE Black Sea for the penultimate deglaciation - Eemian (134-119 ka), last glacial (64-23 ka) and last deglaciation - Holocene (18 ka - present) periods. The reconstruction is based on the records from the sediment cores 22-GC3, 22-GC8 and 25-GC1, and provides information on vegetation successions in Northern Anatolia and on changes in the Black Sea sea-surface conditions.

The pollen data reveal the dominance of Artemisia steppe in Northern Anatolia during glacial stadials, suggesting rather dry/cold conditions. Temperature and humidity increased during the last and penultimate deglaciations and the last glacial interstadials, which is clearly indicated by development of oak and pines forests. This development can be explained by northwards movement of the summer position of westerlies. The onset of the interglacial conditions in Northern Anatolia is reflected by establishment of euxinian forests. The main difference in both interglacial pollen records is the relatively high amount of the submediterranean Ostrya-type during the Eemian, indicating warmer summer temperatures, compared to the Holocene. The wide distribution of Fagus in Northern Anatolia during the Eemian contrasts with the European records and could be explained by climatic and genetic factors. Pollen assemblages indicate a reduction in forest cover after $5 \mathrm{ka}$ BP, possibly caused by an increased anthropogenic pressure on the vegetation.
\end{abstract}

The dinocyst record indicates lacustrine conditions in the Black Sea during the glacials and shows a change from freshwater/brackish assemblages (Pyxidinopsis psilata, Spiniferites cruciformis) to more marine assemblages (Lingulodinium machaerophorum, Spiniferites ramosus complex) in the Eemian and the Holocene, due to the inflow of saline Mediterranean water. Dinoflagellate cyst assemblages (Tuberculodinium vancampoae, Spiniferites pachydermus, S. mirabilis, Bitectatodinium tepikiense) suggest relatively high sea-surface salinity ( 28-30) and sea-surface temperatures during the Eemian, comparing to the Holocene ( 15-20). The establishment of high sea-surface salinity during the Eemian correlates very well with relatively high global sea-level and is explained as a combined effect of increased Mediterranean supply and increased evaporation at the beginning of the last interglacial.

The first results of the comparison of pollen spectra from surface of the Black Sea core 22-GC3 with such from surface samples collected in Northern Anatolia suggest that the main pollen source area for cores 22-GC3/8 is the adjacent coastal regions of Northern Anatolia and adjacent northern slopes of the Pontic Mountains. 


\section{INTRODUCTION}

\section{Background}

The modern global warming phenomen has stimulated increased interest in past climate dynamics and induced the collection of new data, as well as model developments to better understand the present and predict future climate dynamics (Otto-Bliesner et al., 2006; Meehl et al., 2007; Hederl and Russon, 2011). In this respect, the last interglacial (Eemian) with a duration from $\sim 130 \pm 1$ to $116 \pm 1 \mathrm{ka}$ (Jansen et al., 2007) is often considered as a possible scenario of climatic changes in the near future (Kukla et al., 2002; Otto-Bliesner et al., 2006). During this period, $\sim 2^{\circ} \mathrm{C}$ higher than modern global temperatures caused intensive melting of glaciers, which led to a 4-6 m higher than present sea-level (Cuffey and Marshall, 2000; Otto-Bliesner et al., 2006; Rohling et al., 2007). Present rapid climate changes also prompts another important question about the rate and amplitude of ecosystem reactions to similar abrupt changes in the past (Wunsch, 2006; Jansen et al., 2007). Repeated abrupt climate changes occurred throughout the last glacial interval and have been clearly detected by ice, terrestrial and oceanic climate records (Rahmstorf, 2002; Jansen et al., 2007). The most drastic of such changes were the Dansgaard-Oeschger (D-O) events, detected in Greenland ice cores (Dandgaard et al., 1993; Grootes et al., 1993) and characterized by 8 to $16^{\circ} \mathrm{C}$ warming in Greenland occurring over a few decades, followed by cooling (Rahmstorf, 2002; MassonDelmotte et al., 2005; Jansen et al., 2007). Rapid cooling is also indicated by diagnostic icerafted detritus (IRD) in the ocean sediments and known as Heinrich events (HE) (Heinrich, 1988; Hemming, 2004), which are correlated to D-O stadials (Bond et al., 1993; Bond and Lotti, 1995). HE were caused by large discharges of icebergs into the northern Atlantic, leading to a reduction in sea-surface salinity and surface cooling, and lasted hundreds to thousands of years (Bond and Lotti, 1995; Rahmstorf, 2002; Jansen et al., 2007). Although reasons for $\mathrm{D}-\mathrm{O}$ and $\mathrm{H}$ events are still under discussion, both events are related to changes in thermohaline circulation and wind systems and had pronounced effects on the palaeoenvironment in Europe (Bond et al., 1993; Bond and Lotti, 1995; Sánchez-Goñi et al., 2002; Wunsch, 2006; Fletcher et al., 2010).

New insights on the impact of global palaeoclimate changes on regional scales are provided by studies on high-resolution palaeoarchives from different regions, especially in socalled key regions. These are influenced by two or three different climatic systems and therefore reacted extremely sensitively to palaeoclimatic and palaeoenvironmental changes on both global and regional scales. Marine archives are of particular interest as they provide the 
possibility of land-sea correlations and deciphering of leads and lags of ecosystem reactions (Shackleton et al., 2003). One of the key regions is the Mediterranean (Fig. 1), which is influenced by both low and high-latitude climatic systems (e.g. Sánchez-Goñi et al., 2002). Atmosphere-ocean-land palaeoclimate studies have been successfully performed in the western and central Mediterranean region and demonstrate the close link of Mediterranean climate to the North Atlantic ocean-atmosphere system during the last interglacial (SánchezGoñi et al., 1999, 2005), the last glacial cycle (Cacho et al., 2000; Sánchez-Goñi et al., 2000; Combourieu-Nebout et al., 2002; Moreno et al., 2002; Sánchez-Goñi et al., 2002; Moreno et al., 2004, 2005) and the last glacial-interglacial transition (Cacho et al., 2001, 2002).

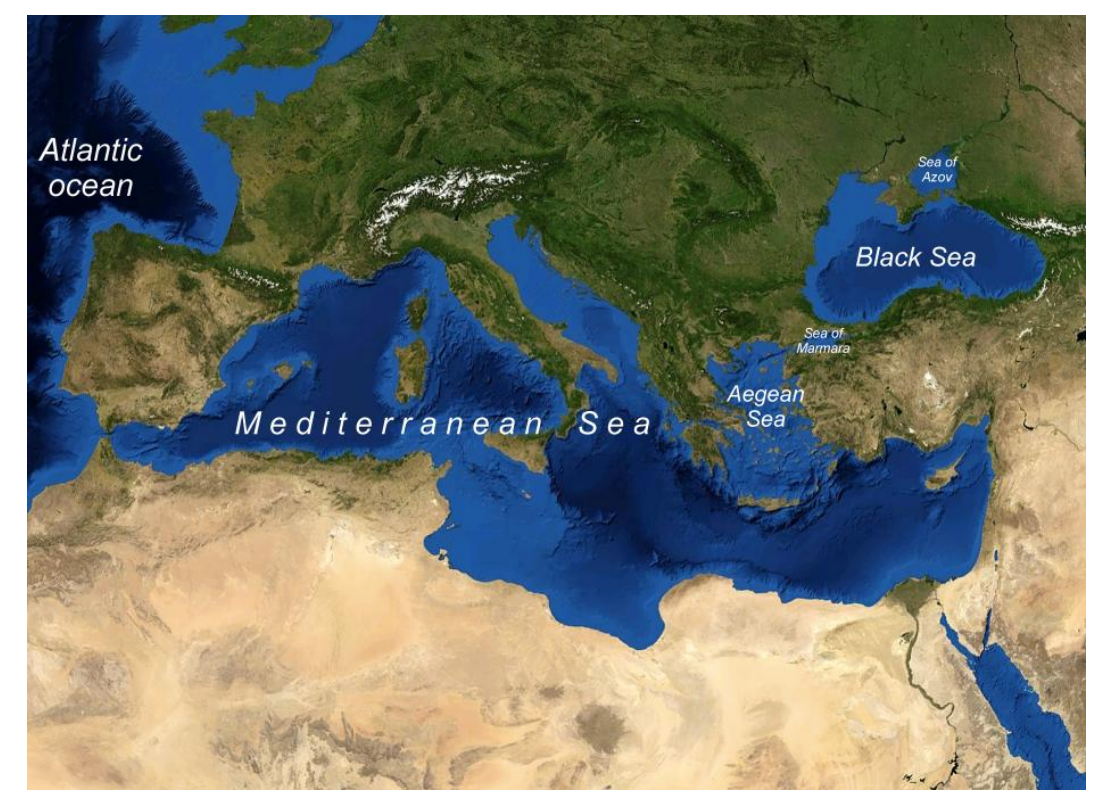

Fig. 1. Map of the Mediterranean region (map source: screenshot from NASA World Wind, download from www.wikipedia.org).

In contrast, in the Eastern Mediterranean region multi-proxy records providing detailed information on ocean-atmosphere-land interaction are sparse. The most long-term palaeoenvironmental studies are based on data from lakes (Tzedakis, 2007) and can be used only for indirect land-sea correlations. Foraminiferal $\delta^{18} \mathrm{O}$ and pollen records from the only continuous marine sequence MD84627 cover the last $250 \mathrm{ka}$, and suggest that the regional climate of the Levantine Basin borderlands had the same temporal pattern as the global ice volume, documented by the ice volume curve (Cheddadi and Rossingol-Strick, 1995). However, low temporal resolutions do not allow the study of palaeoclimate variability in detail. More detailed palaeorecords from the region exist for the last glacial-interglacial transition and the Holocene. However, pollen (Bottema et al., 1995; Kotthoff et al., 2008; Litt et al., 2009; Müller et al., 2011), mountain glaciers (Sarikaya et al., 2008) or 
geomorphological records (Roberts, 1983; Bartov et al., 2003) show opposite moisture trends. The compilation and explanation of these contracsting records remains challenging. In order to provide new high-resolution multi-proxy records for palaeoclimatic and other palaeoenvironmental reconstructions in the Eastern Mediterranean region, the DFG project "Dynamics of Mid-latitude/Mediterranean climate in Northern Anatolia/Black Sea region during the last $150 \mathrm{kyr}$ " was established. The basis for this reconstruction is provided by several sediment cores from the SE Black Sea basin, taken during coring operations in 2005 and 2007. The cores cover the time period since the penultimate glacial-interglacial transition $\sim 134$ ka BP until the present.

\section{Previous palaeostudies from the Black Sea and surrounding regions}

\subsection{Pleistocene evolution of the Black Sea basin}

The first Pleistocene palaeostudies of the Black Sea sediments were carried out by N.I. Andrusov (1890), who documented the Caspian mollusc fauna in the Black Sea deep-sea sediments and suggested its connection to the Caspian Sea in the past. Further geological and stratigraphical studies were carried out mainly on cross-sections on the Black Sea coast, e.g. A.D. Arkhangel'skii and N.M Strakhov (1938), L.A. Nevesskaya (1965), P.V. Fedorov (1978), A.A. Svitoch (2003). The information about Quaternary deposits in the basin was obtained after cruise 49 on research vessel Atlantis in 1969 (Ross and Degens, 1974) and cruise 42 on drilling vessel Glomar Challenger in 1975 (Ross et al., 1978; Neprochnov, 1980). All these geological studies revealed that the Pleistocene history of the Black Sea has a complicated character due to connections with Caspian Sea on one side, and the Mediterranean on the other (Fig. 2). During glacial periods, when global and Mediterranean sea-level was below the depth of the Bosphorus sill, the Black Sea was cut off from the Mediterranean Sea (Fig. 2) and turned into a giant freshwater/brackish lake (Ross et al., 1978; Neprochnov, 1980; Svitoch, 2008; Badertscher et al., 2011). In contrast, during interglacial periods and high global sea levels, saline Mediterranean water spilled into the Black Sea (Fig. 2) and salinity in the Black Sea substantially increased. Several of these drastic hydrological changes from a freshwater/brackish into a brackish/marine stage are documented in sedimentary sequences (Ross et al., 1978; Neprochnov, 1980; Svitoch, 2008) and suggested by speleothems (Badertscher et al., 2011).

The last intrusion of Mediterranean water into the Black Sea took place at the beginning of the Holocene ( 9.3 ka BP; Bahr et al., 2008) and was a subject of numerous discussions in the media, initiated by the book of Ryan and Pittman "Noah's Flood: the new scientific 
discoveries about the event that changed history", published in 1998. The authors suggested that the Biblical Flood is a historical description of a catastrophic event that took place on the Black Sea coast. They argued that in the early Holocene, the sea-level of the Black Sea was much lower than present and its coasts were settled by people. The global sea-level rapidly reached the Bosphorus and led to an abrupt discharge of Mediterranean water into the Black Sea basin, leading to a rapid and catastrophic increase in the Black Sea level and the drowning of people.
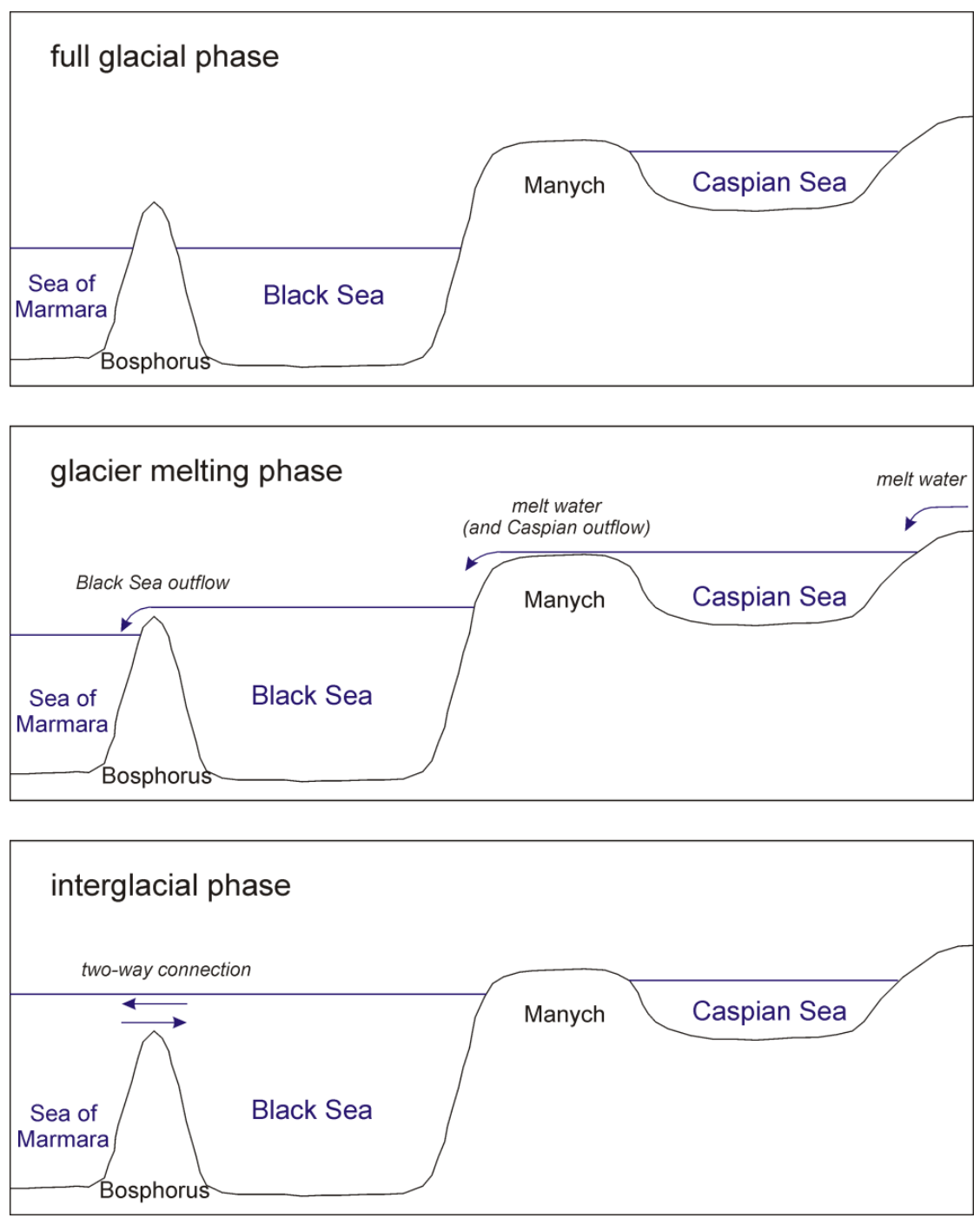

Fig. 2. Simplified Pleistocene history of the Black Sea basin with three main phases (Svitoch 2008): full glacial phase without connections to the Mediterranean or Caspian Seas; melt water input during glacier melting phase led to increase of the sea-level of Caspian and Black Seas, their possible connection and outflow from the Black Sea into the Mediterranean; during the interglacial phase, high global sea-level caused two-way Black Sea-Mediterranean connection.

In order to confirm or disprove the "Noah's flood hypothesis", the last Mediterranean intrusion has been intensively studied. As a result, numerous biological, sedimentological and geochemical sediment records provide detailed information on the hydrological state of the 
Black Sea for the last 25 ka (e.g. Bahr et al., 2005, 2006; Lamy et al., 2006; Yanko-Hombach et al., 2007; Bahr et al., 2008; Kwiecien et al., 2008, 2009; Buynevich et al., 2011) and revealed a gradual, non-catastrophic reconnection. All these and other recent studies (Lamy et al., 2006; Nowaczyk et al., 2012) demonstrate the unique potential of the Black Sea sediments for high-resolution palaeoclimatic and palaeoenvironmental reconstructions.

\subsection{Pollen records from the Black Sea and surrounding regions}

There are plenty of pollen records from the Black Sea and surrounding regions, covering the last glacial and the Holocene (Fig. 3).

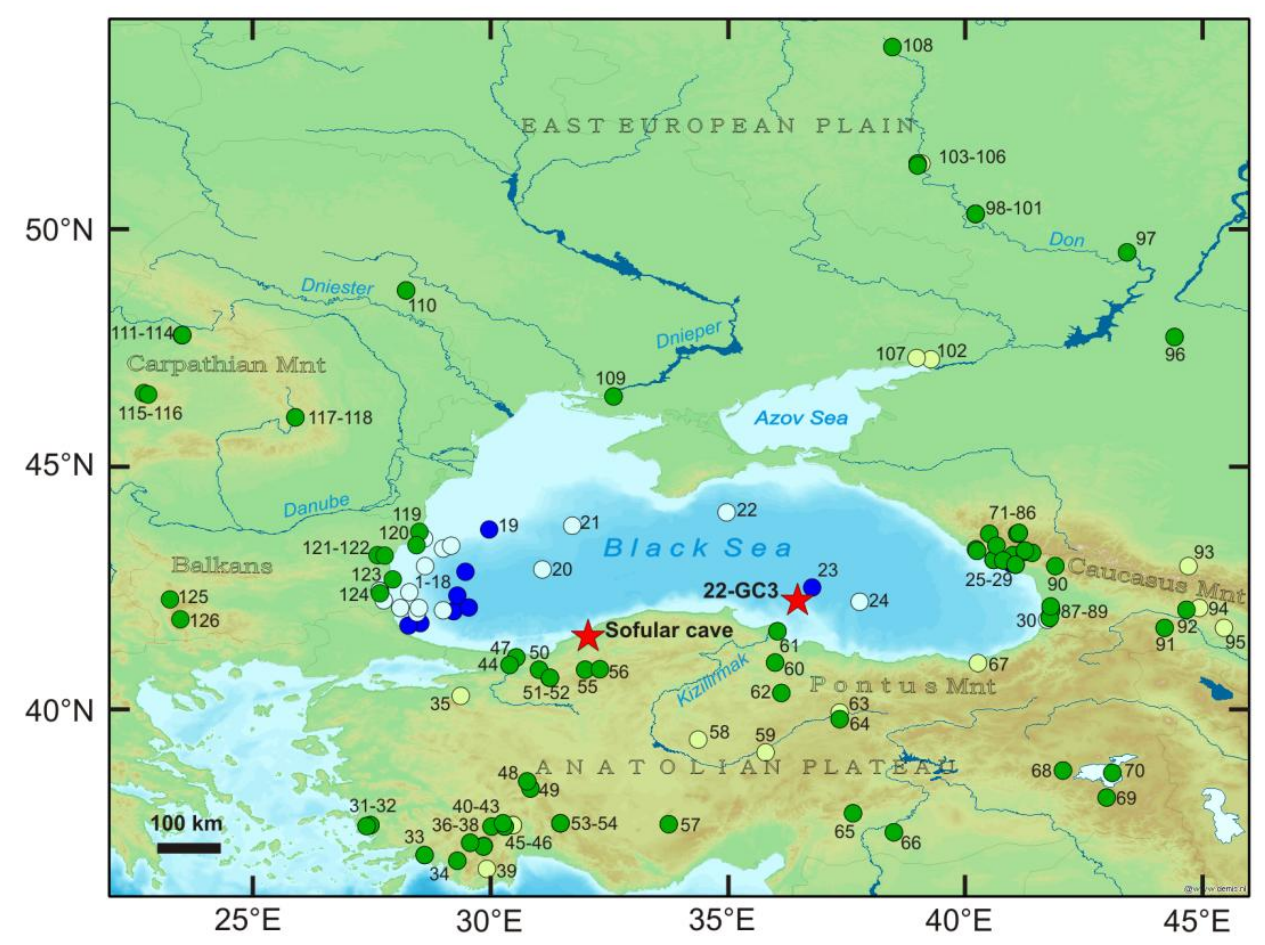

Fig. 3. Physiographic map of the Black Sea region showing locations of the late-glacial Holocene pollen records from the Black Sea and surrounding region. Light-blue circles indicate undated marine cores, dark-blue - dated marine records, yellow - undated terrestrial records, green - dated terrestrial records, red stars show locations of the studied marine core 22-GC3 and of the Sofular Cave. Map sources: www.bgr.de, www.nowcoast.noaa.gov, www2.demis.nl.

In spite of this amount, only 9 (5 marine and 4 terrestrial) from all 126 pollen records continuously cover the deglaciation and the Holocene (at least the last 15-16 ka) (Table 1). From these continuous records, only one terrestrial profile, Steregoiu from the Carpathian mountains (Nr 114 in Fig. 3 and Table 1) (Björkman et al., 2003), has a good age-depth model based on 17 radiocarbon dates. Five records ( 2 marine and 3 terrestrial) have 1-4 radiocarbon dates and the remaining three marine records are not dated at all (Table 1). 
Table 1. Site information on the late glacial - Holocene pollen records from the Black Sea and surrounding regions (Fig. 3).

\begin{tabular}{|c|c|c|c|c|c|c|c|c|}
\hline $\mathrm{Nr}$ & Pollen record & Lat & Long & Alt & $\begin{array}{l}\mathrm{C}^{14} \\
\text { dates }\end{array}$ & $\begin{array}{l}\text { Age } \\
\text { interval* }\end{array}$ & Sediment & Reference \\
\hline \multicolumn{9}{|c|}{ Black Sea } \\
\hline 1 & Soz-F & 42.43 & 27.69 & -5 & $?$ & $0-7$ & marine & Filipova-Marinova, 2006 \\
\hline 2 & Soz-D & 42.43 & 27.70 & -4.4 & 1 & $5-8$ & marine & Filipova-Marinova, 2006 \\
\hline 3 & Urd-F & 42.23 & 27.78 & -1.6 & $?$ & $4-6$ & marine & Filipova-Marinova, 2006 \\
\hline 4 & 85 & 42.07 & 28.13 & -96 & 0 & $5-12$ & marine & $\begin{array}{l}\text { Filipova et al., 1983; Filipova- } \\
\text { Marinova, } 2006\end{array}$ \\
\hline 5 & MAR 02-45 & 41.70 & 28.30 & -69 & 3 & $0-9.4$ & marine & Mudie et al., 2007 \\
\hline 6 & 2345 & 42.40 & 28.32 & -122 & $?$ & $0-30$ & marine & Filipova-Marinova, 2006 \\
\hline 7 & G143 & 41.97 & 28.48 & -90 & 0 & $0-10$ & marine & Atanassova and Božilova, 1992 \\
\hline 8 & 84 & 42.07 & 28.52 & -92 & 0 & $0-12$ & marine & $\begin{array}{l}\text { Filipova et al., 1983; Filipova- } \\
\text { Marinova, } 2006\end{array}$ \\
\hline 9 & XK120 & 41.75 & 28.55 & -94 & 1 & $0-15$ & marine & $\begin{array}{l}\text { Božilova et al., 1992; Shopov et al., } \\
\text { 1992; Atanassova, } 2005\end{array}$ \\
\hline 10 & 3-Apr & 43.53 & 28.63 & -61 & 0 & $5-870$ & marine & Filipova-Marinova, 2006 \\
\hline 11 & 19 & 42.95 & 28.65 & -850 & 0 & $0-9$ & marine & $\begin{array}{l}\text { Filipova et al., 1983; Filipova- } \\
\text { Marinova, } 2006\end{array}$ \\
\hline 12 & XK147 & 43.32 & 29.03 & -1425 & 0 & $0-10$ & marine & Atanassova and Božilova, 1992 \\
\hline 13 & G142 & 42.02 & 29.03 & -1500 & 0 & $0-10$ & marine & Atanassova and Božilova, 1992 \\
\hline 14 & 18 & 43.38 & 29.20 & -160 & $?$ & $0-8$ & marine & Filipova-Marinova, 2006 \\
\hline 15 & XK55 & 42.00 & 29.25 & -1470 & 1 & $0-10$ & marine & $\begin{array}{l}\text { Božilova et al., 1992; Shopov et al., } \\
\text { 1992; Atanassova, 2005 }\end{array}$ \\
\hline 16 & A159 & 42.33 & 29.33 & -1950 & 3 & $0-12$ & marine & Atanassova, 2005 \\
\hline 17 & E26 & 42.83 & 29.50 & -2260 & 2 & $0-11$ & marine & $\begin{array}{l}\text { Božilova et al., 1992; Shopov et al., } \\
\text { 1992; Atanassova, 2005 }\end{array}$ \\
\hline 18 & 544 & 42.08 & 29.57 & -2500 & 3 & $0-12$ & marine & $\begin{array}{l}\text { Božilova et al., 1992; Filipova- } \\
\text { Marinova, } 2006\end{array}$ \\
\hline 19 & XK71 & 43.72 & 30.00 & -520 & 1 & $0-10$ & marine & $\begin{array}{l}\text { Božilova et al., 1992; Shopov et al., } \\
\text { 1992; Atanassova, } 2005\end{array}$ \\
\hline 20 & 1 & 42.88 & 31.12 & -2130 & $?$ & $0-12$ & marine & Filipova-Marinova, 2006 \\
\hline 21 & 1444 & 43.80 & 31.75 & -1597 & 0 & $0-20$ & marine & Koreneva and Kartashova, 1978 \\
\hline 22 & 1433 & 44.08 & 35.00 & -2225 & 0 & $0-11$ & marine & Koreneva and Kartashova, 1978 \\
\hline 23 & B-7 & 42.50 & 36.80 & -2120 & 3 & $0-9.5$ & marine & Mudie et al., 2002a; Mudie et al., 2007 \\
\hline 24 & 1474 & 42.20 & 37.80 & -2117 & 0 & $0-25$ & marine & Traverse, 1974 \\
\hline 25 & Gudauta 521 & 43.10 & 40.63 & -31.8 & 0 & $0-10$ & marine & Shatilova et al., 2011 \\
\hline 26 & $\begin{array}{l}\text { Akhali Atheni } \\
511\end{array}$ & 43.07 & 40.82 & -14.7 & 0 & $0-10$ & marine & Shatilova et al., 2011 \\
\hline 27 & Sokhumi 36 & 43.00 & 41.00 & 0 & 1 & $0-20$ & marine & Kvavadze and Rukhadze, 1989 \\
\hline 28 & Sokhumi 721 & 43.00 & 41.00 & -14.9 & 2 & $0-10$ & marine & Kvavadze and Rukhadze, 1989 \\
\hline 29 & Sokhumi 723 & 43.00 & 41.00 & -9.8 & 4 & $0-10$ & marine & $\begin{array}{l}\text { Kvavadze and Rukhadze, 1989; } \\
\text { Shatilova et al., } 2011\end{array}$ \\
\hline 30 & Kobuleti 39 & 41.82 & 41.75 & 0 & 0 & $0-8$ & marine & Shatilova et al., 2011 \\
\hline \multicolumn{9}{|c|}{ Anatolia } \\
\hline 31 & Bafa S6 & 37.48 & 27.42 & 0 & 3 & $0-2.7$ & lake & Knipping et al., 2008 \\
\hline 32 & Bafa S1 & 37.50 & 27.50 & 0 & 2 & $0-4$ & lake & $\begin{array}{l}\text { Müllenhoff et al., 2004; Knipping et } \\
\text { al., } 2008\end{array}$ \\
\hline 33 & Köyceğis Gölü & 36.87 & 28.64 & 0 & 2 & $0-5$ & lake & Van Zeist et al., 1975 \\
\hline 34 & Ova Gölü & 36.75 & 29.33 & 0 & 2 & $0-6$ & lake & Bottema and Woldring, 1984 \\
\hline 35 & Yenişehir Gölü & 40.22 & 29.40 & 250 & 0 & $0-10$ & lake & Bottema and Woldring, 1995a \\
\hline 36 & Gölhisar & 37.13 & 29.60 & 930 & 8 & $0-11 \mathrm{cal}$ & lake & $\begin{array}{l}\text { Bottema and Woldring, 1984; } \\
\text { Eastwood et al., } 2007\end{array}$ \\
\hline 37 & Söğüt Gölü & 37.05 & 29.88 & 1393 & 2 & $0-30$ & lake & Van Zeist et al., 1975 \\
\hline 38 & Elmali & 37.07 & 29.89 & 930 & 0 & $0-4$ & lake & Bottema and Woldring, 1984 \\
\hline 39 & Avlan Gölü & 36.58 & 29.95 & 1043 & 0 & $0-8$ & lake & Bottema and Woldring, 1984 \\
\hline 40 & Pinarbaşi & 37.47 & 30.05 & 980 & 2 & $0-6$ & lake & Bottema and Woldring, 1984 \\
\hline 41 & Bereket & 37.54 & 30.29 & 1410 & 11 & $0-3.5$ & alluvial fan & Kaniewski et al., 2007 \\
\hline 42 & Gravgaz G96 & 37.47 & 30.33 & 1000 & 3 & $0-2.5$ & peat & Vermoere et al., 2002 \\
\hline 43 & Gravgaz G99 & 37.47 & 30.33 & 1000 & 6 & $0-2.5$ & peat & Vermoere et al., 2002 \\
\hline 44 & Küçük Gölü & 40.87 & 30.43 & 50 & 2 & $0-3$ & lake & Bottema et al., 1995 \\
\hline 45 & Çanaklı & 37.50 & 30.50 & 1000 & 0 & $0-3.5$ & lake & Bottema and Woldring, 1995b \\
\hline
\end{tabular}




\begin{tabular}{|c|c|c|c|c|c|c|c|c|}
\hline 46 & Çanaklı & 37.50 & 30.50 & 1000 & 0 & $0-2.4$ & lake & Vermoere et al., 2002 \\
\hline 47 & Akgöl Adatepe & 41.03 & 30.57 & 50 & 1 & $0-0.9$ & lake & Bottema et al., 1995 \\
\hline 48 & $\begin{array}{l}\text { Karamik } \\
\text { Batakliği }\end{array}$ & 38.42 & 30.80 & 1000 & 2 & $0-20$ & peat & Van Zeist et al., 1975 \\
\hline 49 & Hoyran Gölü & 38.27 & 30.87 & 916 & 1 & $0-4$ & lake & Van Zeist et al., 1975 \\
\hline 50 & Melen Gölü & 40.77 & 31.05 & 125 & 1 & $0-3$ & lake & Bottema et al., 1995 \\
\hline 51 & Abant Gölü & 40.60 & 31.27 & 1298 & 0 & $0-4$ & lake & Beug, 1967 \\
\hline 52 & Abant Gölü & 40.60 & 31.28 & 1300 & 5 & $0-10$ & lake & Bottema et al., 1995 \\
\hline 53 & Beyşehir Gölü & 37.54 & 31.50 & 1120 & 2 & $0-8$ & lake & Van Zeist et al., 1975 \\
\hline 54 & Beyşehir Gölü II & 37.54 & 31.50 & 1120 & 1 & $8-15$ & lake & Bottema and Woldring, 1984 \\
\hline 55 & Yeniçağa Gölü & 40.77 & 32.02 & 976 & 2 & $0-5.3$ & lake & Beug, 1967 \\
\hline 56 & Yeniçağa Gölü & 40.78 & 32.33 & 976 & 5 & $4-13$ & lake & Bottema et al., 1995 \\
\hline 57 & $\begin{array}{l}\text { Akgöl Adabă̆ } \\
\text { (Ereğli) }\end{array}$ & 37.52 & 33.78 & 1000 & 3 & $6-13$ & peat & Bottema and Woldring, 1984 \\
\hline 58 & Seyfe Gölü & 39.30 & 34.40 & 1080 & 0 & $1-2$ & lake & Bottema et al., 1995 \\
\hline 59 & Tuzla Gölü & 39.03 & 35.82 & 900 & 0 & $0-3$ & lake & Bottema et al., 1995 \\
\hline 60 & Lâdik Gölü & 40.92 & 36.02 & 800 & 4 & $0-14$ & lake & Bottema et al., 1995 \\
\hline 61 & Tatlı Gölü & 41.58 & 36.07 & 0 & 1 & $0-6$ & lake & Bottema et al., 1995 \\
\hline 62 & Kaz Gölü & 40.28 & 36.15 & 500 & 2 & $0-8.7$ & lake & Bottema et al., 1995 \\
\hline 63 & Büyük Gölü & 39.87 & 37.38 & 1300 & 0 & $0-1$ & lake & Bottema et al., 1995 \\
\hline 64 & Demiryurt Gölü & 39.73 & 37.38 & 1300 & 1 & $0-2$ & lake & Bottema et al., 1995 \\
\hline 65 & Gölbaşi & 37.75 & 37.66 & 890 & 1 & $0-3$ & lake & Van Zeist et al., 1970 \\
\hline 66 & Bozova & 37.35 & 38.52 & 890 & 1 & $0-2.6$ & lake & Van Zeist et al., 1970 \\
\hline 67 & $\begin{array}{l}\text { Sürmene- } \\
\text { Ağaçbaş1 }\end{array}$ & 40.91 & 40.29 & 1887 & 0 & $0-9$ & peat & Aytuğ et al., 1975 \\
\hline 68 & Söğütlü & 38.65 & 42.08 & 1500 & 3 & $0-7.3$ & peat & Bottema, 1995 \\
\hline 69 & Van & 38.08 & 43.00 & 1646 & varves & $0-9.8 \mathrm{cal}$ & lake & Van Zeist and Woldring, 1978 \\
\hline 70 & Van $90-4$ & 38.60 & 43.12 & 1648 & varves & $\begin{array}{l}0-12.5 \\
\text { cal }\end{array}$ & lake & Wick et al., 2003 \\
\hline \multicolumn{9}{|c|}{ Caucasus } \\
\hline 71 & Gagra 471 & 43.30 & 40.25 & 5 & 2 & $0-10$ & peat, clay & $\begin{array}{l}\text { Kvavadze and Rukhadze, 1989; } \\
\text { Shatilova et al., } 2011\end{array}$ \\
\hline 72 & Gagra 607 & 43.27 & 40.27 & 0 & 2 & $4-6$ & marine & Kvavadze and Rukhadze, 1989 \\
\hline 73 & Bathing Chamois & 43.63 & 40.53 & 2485 & 2 & $0-5$ & lake & Kvavadze and Efremov, 1994 \\
\hline 74 & Gudauta 120 & 43.08 & 40.62 & 0 & 1 & $0-11$ & clay & Kvavadze and Rukhadze, 1989 \\
\hline 75 & Akhali Ateni 182 & 43.07 & 40.82 & 60 & 0 & $5-7$ & clay, peat & Kvavadze and Rukhadze, 1989 \\
\hline 76 & Luganskoe & 43.38 & 40.68 & 2428 & 2 & $0-5$ & peat & Kvavadze and Efremov, 1996 \\
\hline 77 & Akhali Ateni 55 & 43.07 & 40.82 & 0 & 2 & $5.2-6.8$ & $\begin{array}{l}\text { alluvial } \\
\text { terrace }\end{array}$ & $\begin{array}{l}\text { Kvavadze and Rukhadze,1989; } \\
\text { Kvavadze and Connor, } 2005\end{array}$ \\
\hline 78 & Chamlukh & 43.18 & 41.03 & 1650 & 1 & $0-4$ & peat & Yazvenko, 1994 \\
\hline 79 & Dziguta 1 & 42.98 & 41.08 & 120 & 9 & $9-29$ & peat, gyttja & Arslanov et al., 2007 \\
\hline 80 & Dziguta 75 & 42.98 & 41.08 & 120 & 5 & $37-48$ & peat, gyttja & Arslanov et al., 2007 \\
\hline 81 & Bluzovie & 43.63 & 41.12 & 2884 & 0 & $0-4$ & paleosoil & Kvavadze and Efremov, 1996 \\
\hline 82 & Kvartsevoe & 43.63 & 41.12 & 2726 & 1 & $0-6$ & peat & Kvavadze and Efremov, 1996 \\
\hline 83 & Rybnoe & 43.65 & 41.15 & 2151 & 2 & $0-2$ & peat & Kvavadze and Efremov, 1996 \\
\hline 84 & Adange & 43.28 & 41.28 & 1750 & 3 & $0-3$ & peat & Kvavadze and Rukhadze, 1989 \\
\hline 85 & Amtkel & 43.25 & 41.28 & 1830 & 2 & $0-2$ & peat & Kvavadze and Rukhadze, 1989 \\
\hline 86 & Sibista & 43.23 & 41.43 & 2160 & 2 & $0-2$ & peat & Kvavadze and Rukhadze, 1989 \\
\hline 87 & Ispani-II & 41.86 & 41.80 & 2 & 3 & $0-5.7$ & peat & Connor et al., 2007 \\
\hline 88 & Imnatian Lake & 42.10 & 41.82 & 2 & 4 & $0-7$ & peat & $\begin{array}{l}\text { Neishtadt et al., 1965; Shatilova et al., } \\
2011\end{array}$ \\
\hline 89 & Supsa 2 & 42.02 & 41.83 & 10 & 1 & $0-2$ & $\begin{array}{l}\text { alluvial } \\
\text { terrace }\end{array}$ & Kvavadze and Connor, 2005 \\
\hline 90 & Malyi Khodzhal & 42.95 & 41.92 & 2030 & 1 & $0-1.2$ & peat & Kvavadze and Rukhadze, 1989 \\
\hline 91 & Imera & 41.65 & 44.22 & 1610 & 4 & $0-7$ & lake & Kvavadze and Connor, 2005 \\
\hline 92 & Bazaleti B & 42.03 & 44.68 & 875 & 1 & $0-3$ & lake & Kvavadze and Connor, 2005 \\
\hline 93 & Tarskoe & 42.95 & 44.72 & 835 & 0 & $0-6$ & peat & Neustadt, 1955 \\
\hline 94 & Tianeti & 42.07 & 44.95 & 1200 & 0 & $0-10$ & lake & Tumadzhanov and Margalitadze, 1961 \\
\hline 95 & Nasadgomari & 41.65 & 45.47 & 410 & 0 & $0-10$ & lake & Gogichaishvili, 1962 \\
\hline \multicolumn{9}{|c|}{ Russian Plain } \\
\hline 96 & Kharabuluk & 47.77 & 44.43 & 70 & 10 & $0-7$ & peat & Kremenetski et al., 1999 \\
\hline 97 & Lipigi & 49.55 & 43.43 & 160 & 9 & $0-5.3$ & peat & Kremenetski et al., 1999 \\
\hline 98 & Duhovoe & 50.36 & 40.24 & 100 & 2 & $0-3.5$ & paleosoil & Spiridonova, 1991 \\
\hline
\end{tabular}




\begin{tabular}{|c|c|c|c|c|c|c|c|c|}
\hline 99 & Gavrilovo-84 & 50.36 & 40.24 & 100 & 8 & $0-12$ & paleosoil & Spiridonova, 1991 \\
\hline 100 & Gavrilovo-86 & 50.36 & 40.24 & 100 & 6 & $4-10$ & paleosoil & Spiridonova, 1991 \\
\hline 101 & Shkurlat-2 & 50.36 & 40.24 & 100 & 3 & $8-15$ & peat & Spiridonova, 1991 \\
\hline 102 & Nosovo-1 & 47.30 & 39.30 & 6 & 0 & $0-130$ & paleosoil & Spiridonova, 1991 \\
\hline 103 & Malyi Luzhok & 51.42 & 39.10 & 96 & 0 & $0-8$ & paleosoil & Spiridonova, 1991 \\
\hline 104 & Kostenki-1 & 51.42 & 39.02 & 96 & 2 & $21-24$ & paleosoil & Spiridonova, 1991 \\
\hline 105 & Kostenki-8 & 51.40 & 39.02 & 96 & 1 & 27 & paleosoil & Spiridonova, 1991 \\
\hline 106 & Kostenki-17 & 51.38 & 39.02 & 96 & 2 & $26-32$ & paleosoil & Spiridonova, 1991 \\
\hline 107 & Rozhok-1 & 47.33 & 39.00 & 5 & 0 & $40-50$ & paleosoil & Spiridonova, 1991 \\
\hline 108 & Lupishki-2 & 53.87 & 38.49 & 150 & 5 & $0-10$ & peat & Spiridonova, 1991 \\
\hline 109 & Kardashinski & 46.52 & 32.62 & 20 & 7 & $0-8$ & peat & Kremenetski, 1995 \\
\hline 110 & Dovjokk & 48.75 & 28.25 & 244 & 9 & $0-7$ & peat & Kremenetski, 1995 \\
\hline \multicolumn{9}{|c|}{ Carpatian } \\
\hline 111 & Preluca Tiganului & 47.81 & 23.53 & 730 & 6 & $0-12 \mathrm{cal}$ & peat & Feurdean, 2005 \\
\hline 112 & Preluca Tiganului & 47.81 & 23.53 & 730 & 12 & $\begin{array}{l}8.5-15 \\
\text { cal }\end{array}$ & peat & Björkman et al., 2002 \\
\hline 113 & Steregoiu & 47.81 & 23.54 & 790 & 7 & $9-15 \mathrm{cal}$ & peat & Björkman et al., 2002 \\
\hline 114 & Steregoiu & 47.81 & 23.54 & 790 & 17 & $0-15$ cal & peat & Björkman et al., 2003 \\
\hline 115 & Padis Sondori & 46.59 & 22.73 & 1290 & 8 & $0-6.5 \mathrm{cal}$ & peat & Feurdean et al., 2009 \\
\hline 116 & Calineasa & 46.56 & 22.82 & 1360 & 10 & $0-7$ cal & peat & Feurdean et al., 2009 \\
\hline 117 & Mohos 1 & 46.08 & 25.92 & 1050 & 20 & $0-10$ & peat & Tantau et al., 2003 \\
\hline 118 & Mohos 2 & 46.08 & 25.92 & 1050 & 6 & $0-9$ & peat & Tantau et al., 2003 \\
\hline \multicolumn{9}{|c|}{ Balkans } \\
\hline 119 & Durankulak & 43.67 & 28.53 & 0 & 5 & $0-4.5 \mathrm{cal}$ & lake & Marinova and Atanassova, 2006 \\
\hline 120 & Bolata Lake & 43.39 & 28.47 & 0 & 5 & $0-6 \mathrm{cal}$ & lake & Tonkov et al., 2011 \\
\hline 121 & $\begin{array}{l}\text { Poveljanovo 2, } \\
\text { Beloslav lake }\end{array}$ & 43.18 & 27.65 & 0 & 2 & $0-8$ & lake & Božilova and Beug, 1994 \\
\hline 122 & $\begin{array}{l}\text { Arsenala, Varna } \\
\text { lake }\end{array}$ & 43.17 & 27.80 & 0 & 4 & $0-8$ & lake & Božilova and Beug, 1994 \\
\hline 123 & Core 149 & 42.67 & 27.97 & 1.6 & 4 & $0-10$ & $\begin{array}{l}\text { river } \\
\text { terrace }\end{array}$ & Filipova-Marinova, 2006 \\
\hline 124 & Arkutino Lake & 42.38 & 27.70 & 20 & 11 & $0-6.2$ & lake & Božilova and Beug, 1992 \\
\hline 125 & Paniçishte & 42.25 & 23.28 & 1500 & 4 & $0-10$ & peat & Božilova, 1975 \\
\hline 126 & Praso & 41.83 & 23.50 & 875 & 4 & $0-8$ & peat & Stefanova and Oeggl, 1993 \\
\hline
\end{tabular}

Footnote: * age is given in uncalibrated radiocarbon years, calibrated ages are indicated as "cal".

For the Eemian interval, there is only one marine record from the Black Sea and 7 terrestrial records from the region (Fig. 4, Table 2). The ages of all records were defined stratigraphically. From these records, the Tenaghi Philippon (Wijmstra, 1969) and Staro Orjachovo (Božilova and Djankova, 1976) records have relatively high resolution and were correlated with the European pollen records. 


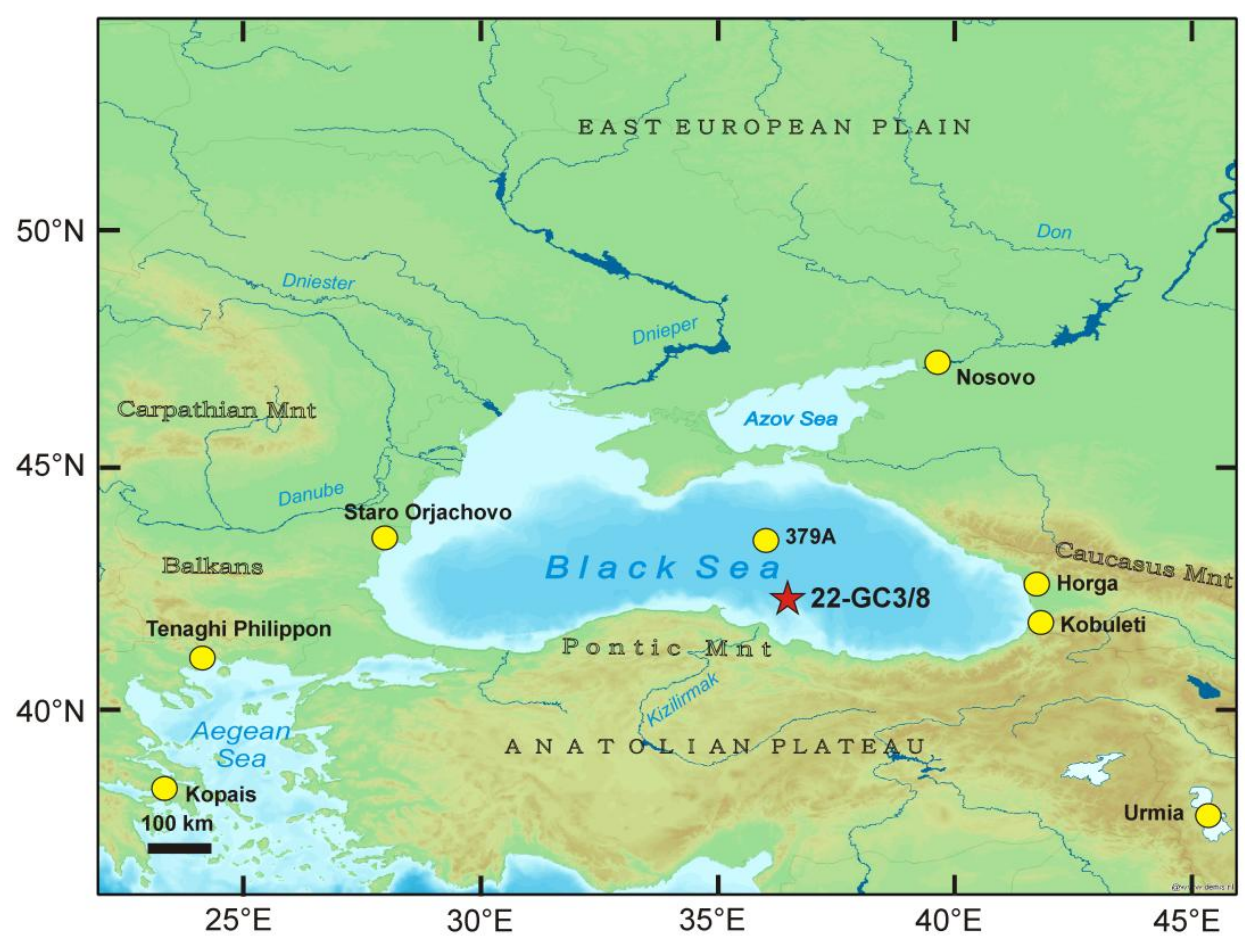

Fig. 4. Physiographic map of the Black Sea region showing locations of the marine core 22GC3/8 (red star) and the Eemian pollen records from the Black Sea and surrounding regions (yellow circles). Map sources: www.bgr.de, www.nowcoast.noaa.gov, www2.demis.nl.

Table 2. Site information for Eemian records from the Black Sea and surrounding regions (Fig. 4).

\begin{tabular}{llllll}
\hline Site & Lat, N & Long, E & Alt, m & Material & Reference \\
\hline 379A & $43^{\circ} 00.29^{\prime}$ & $36^{\circ} 00.68^{\prime}$ & -2173 & marine & Koreneva and Kartashova, 1978 \\
Staro Orjachovo* & $43^{\circ} 00^{\prime}$ & $27^{\circ} 48^{\prime}$ & 50 & lake/river & Božilova and Djankova, 1976 \\
Nosovo-1* $^{*}$ & $47^{\circ} 18^{\prime}$ & $39^{\circ} 18^{\prime}$ & 6 & paleosol & Spiridonova, 1991 \\
Horga* $^{\prime}$ & $42^{\circ} 00^{\prime}$ & $41^{\circ} 50^{\prime}$ & 8 & terrestrial & Shatilova, 1974 \\
Kobuleti* & $41^{\circ} 49^{\prime}$ & $41^{\circ} 46^{\prime}$ & 7 & terrestrial & Shatilova, 1974 \\
Urmia & $37^{\circ} 32^{\prime}$ & $45^{\circ} 05^{\prime}$ & 1315.9 & lake & Djamali et al., 2008 \\
Tenaghi Philippon & $41^{\circ} 10^{\prime}$ & $24^{\circ} 20^{\prime}$ & 40 & peat & Wijmstra, 1969 \\
Kopais & $38^{\circ} 26.27^{\prime}$ & $23^{\circ} 03.02^{\prime}$ & 92.4 & lake & Tzedakis, 1999 \\
\hline
\end{tabular}

Footnote: * geographical coordinates of sites are not reported in the original publication and were georeferenced using gazetteers.

\subsection{Dinoflagellate cyst records from the Black Sea}

The pioneering studies of Wall et al. (1973) and Wall and Dale (1974) on organicwalled dinoflagellate cysts (=dinocysts) provided the first biostratigraphic distribution and palaeoecological relationships of dinocysts for the late Pleniglacial and the Holocene in the Black Sea. A number of sediment cores mainly from the southern part of the Black Sea basin (Fig. 5, Table 3) have highlighted the great potential of dinocysts to estimate sea-surface conditions during the late glacial and the Holocene (Wall et al., 1973; Wall and Dale, 1974; Mudie et al., 2001, 2002b, 2004; Atanassova, 2005; Filipova-Marinova, 2006; Mudie et al., 
2007; Marret et al., 2009; Verleye et al., 2009; Mertens et al., 2012). So far, there is no single dinocyst record from the Black Sea for the last interglacial.

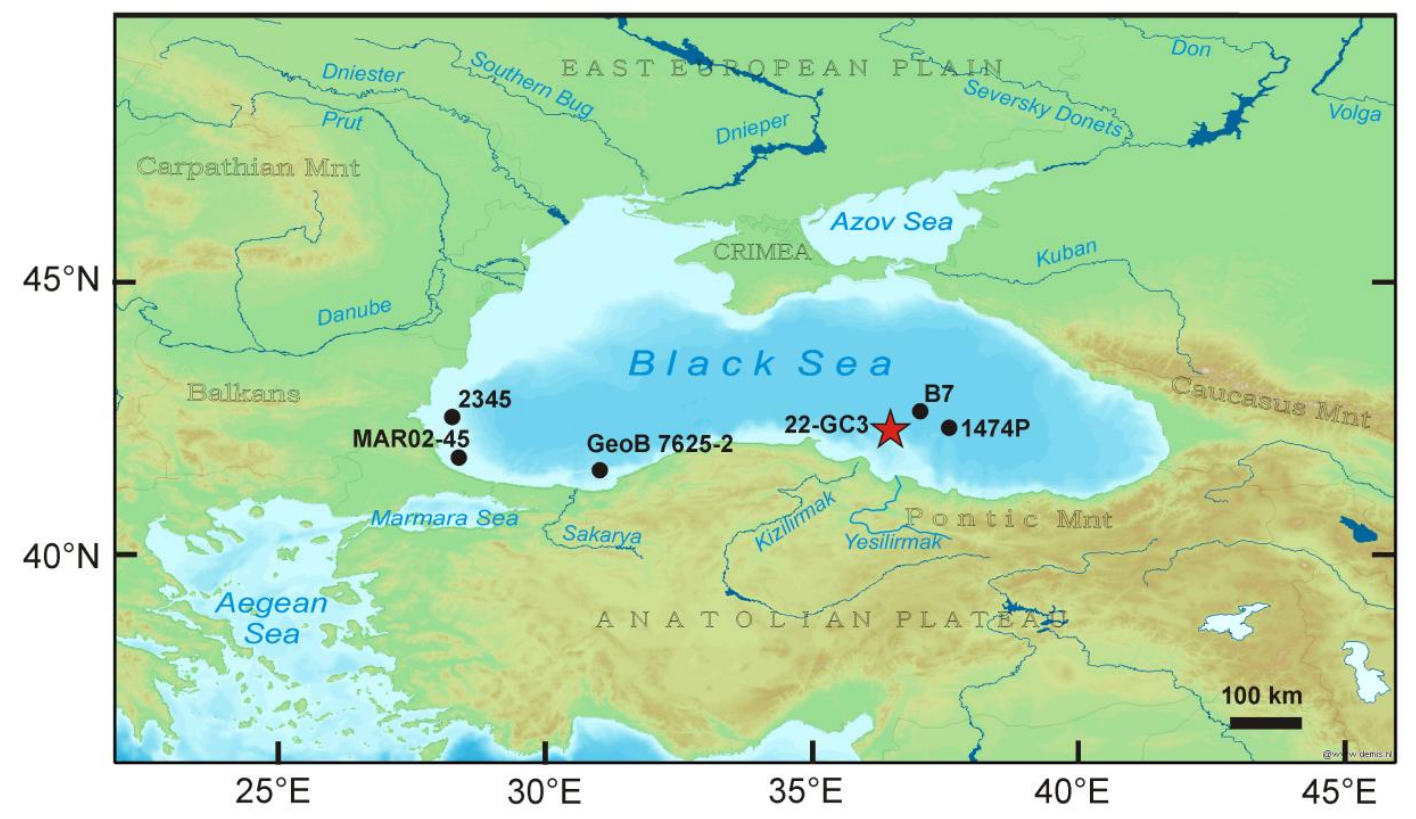

Fig. 5. Physiographic map of the Black Sea region showing locations of the investigated core 22-GC3 (red star) and marine records of dinocysts (black circles). Map sources: www.bgr.de, www.nowcoast.noaa.gov, www2.demis.nl.

Table 3. Site information for dinocyst records from the Black Sea (Fig. 5)

\begin{tabular}{lllll}
\hline Site & Lat, $N$ & Long, E & depth, $\mathrm{m}$ & Reference \\
\hline MAR02-45 & $41^{\circ} 41^{\prime}$ & $28^{\circ} 19^{\prime}$ & 65 & Marret et al., 2009 \\
1474P & $42^{\circ} 23^{\prime}$ & $37^{\circ} 37^{\prime}$ & 2114 & Wall et al., 1973 \\
2345 & $42^{\circ} 24^{\prime}$ & $28^{\circ} 19^{\prime}$ & 122 & Filipova-Marinova, 2006 \\
B7 & $42^{\circ} 30^{\prime}$ & $36^{\circ} 48^{\prime}$ & 2120 & Mudie et al., 2002b \\
GeoB 7625-2 & $41^{\circ} 27^{\prime}$ & $31^{\circ} 04^{\prime}$ & 1242 & Verleye et al., 2009 \\
\hline
\end{tabular}

\section{Motivation and aims}

The main task of the presented work was to carry out palynological studies on cores from the SE Black Sea, covering the last $134 \mathrm{ka}$, in order to provide vegetation and environmental changes in Northern Anatolia/Black Sea region during this period. Thereby, pollen and spores are used for reconstruction of the vegetation, environment and climate changes in Northern Anatolia. Additional studies on organic-walled dinoflagellate cysts (dinocysts) provide information about sea-surface conditions in the Black Sea. Palaeoenvironmental reconstructions of both records are discussed with regard to fungal spores and non-pollen palynomorphs, giving additional information on palaeoenvironmental 
conditions. In order to provide land-sea correlations, records are directly compared to each other.

Due to a special focus of the research on conditions in Northern Anatolia during the Eemian and Holocene as well as abrupt changes during deglaciations and glacial cycle, the main research questions of the presented studies can be summarized as followed:

- What kind of vegetation development occurred during the Eemian and the Holocene in Northern Anatolia?

- How did the sea-surface conditions of the Black Sea change during the last interglacial in comparison to the Holocene period?

- How did marine and terrestrial ecosystems of Northern Anatolia/Black Sea region respond to abrupt changes during the penultimate and the last deglaciations?

- What was the millennial- to centennial-scale response of marine and terrestrial ecosystems in Northern Anatolia/Black Sea region to climatic instability during the last glacial period?

- What can we learn from past environmental changes in Northern Anatolia/Black Sea region regarding future climate change?

\section{Study area}

Studies were carried out on three cores collected during cruise M72/5 of the research vessel Meteor from the southern part of the Black Sea in 2007: cores 22-GC3 and 22-GC8 $\left(42^{\circ} 13.53^{\prime} \mathrm{N}, 36^{\circ} 29.55^{\prime} \mathrm{E}\right.$, water depth $\left.838 \mathrm{~m}\right)$, core $25-\mathrm{GC} 1\left(42^{\circ} 06.2^{\prime} \mathrm{N}, 36^{\circ} 37.4^{\prime} \mathrm{E}\right.$, water depth $418 \mathrm{~m}$ ) (Fig. 6). The coring sites are located only 50-80 km north-east of the Turkish coast, while the distances from the eastern (Georgian), northern (Ukrainian) and western (Bulgarian) coasts of the Black Sea are around 400, 300-500 and $650 \mathrm{~km}$ respectively.

The areas along the northern and north-western coasts of the Black Sea are predominantly plains and lowlands (Fig. 6), except for the Crimean Mountains with maximum elevation of $1,545 \mathrm{~m}$ a.s.l. The mountain relief is more pronounced in the coastal regions south and east of the sea (Fig. 6). The arc of mountain ranges interrupted by river valleys and deltas includes the Caucasus $(5,633 \mathrm{~m})$ in the east, the Pontic Mountains $(3,937$ m) with the Anatolian Plateau in the south, and the Rhodopes (2,925 m), Balkans (2,376 m) and Carpathian Mountains (2,543 m) in the west. 


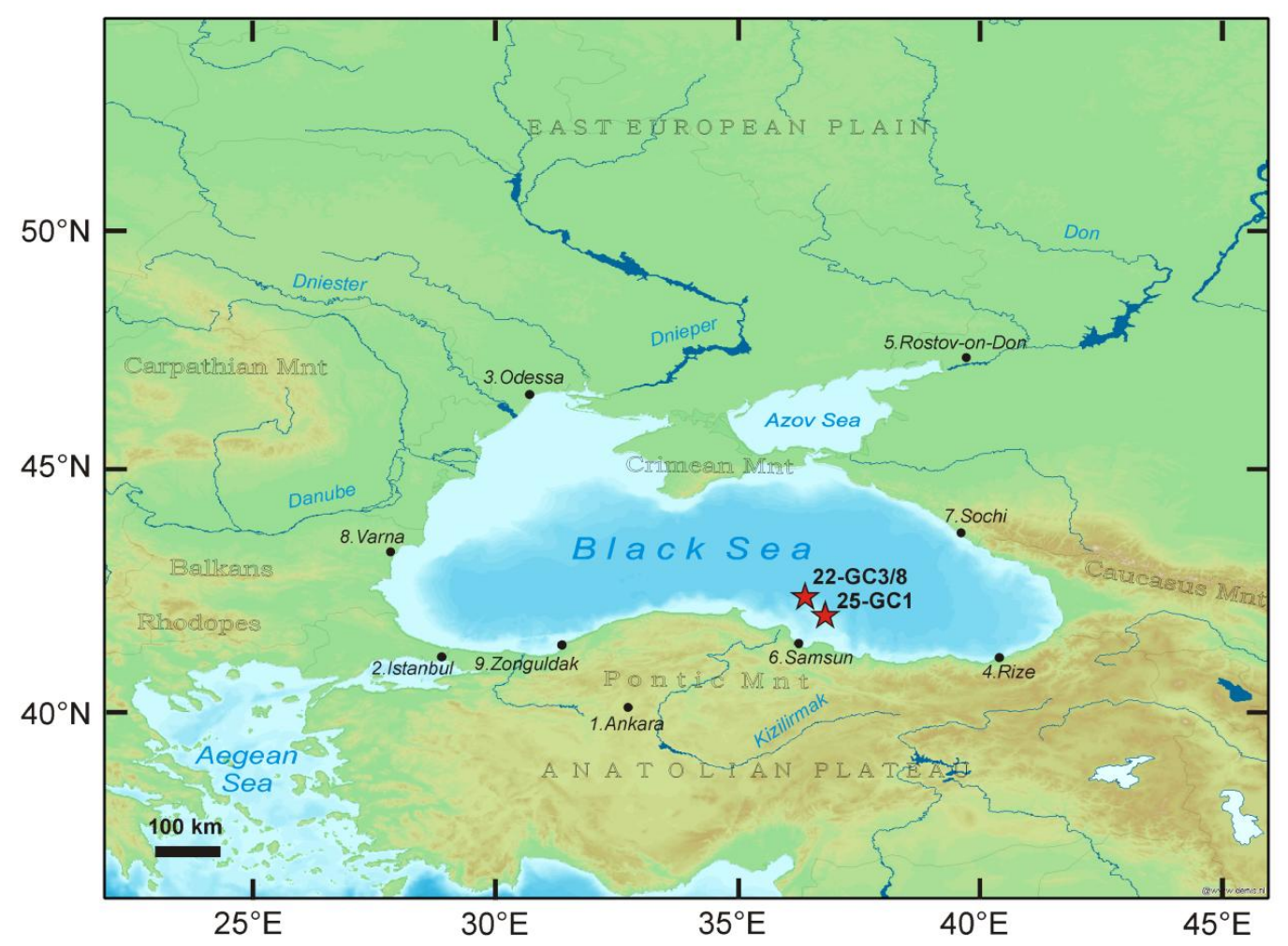

Fig. 6. Physiographical map of the Black Sea region showing locations of the investigated cores 22-GC3/8 and 25-GC1 (red stars). Black dots with numbers and site names indicate locations of the climate stations presented in Table 1. Map was drawn with Quantum GIS (1.7.0) by using data from www.bgr.de, www.nowcoast.noaa.gov, www2.demis.nl.

\subsection{Oceanography}

The Black Sea has a surface area of about $4.23 \times 10^{5} \mathrm{~km}^{2}$, a volume of $5.55 \times 10^{5} \mathrm{~km}^{3}$, and a maximal water depth of $2258 \mathrm{~m}$ (Kosarev and Kostianoy, 2008). The northern part of the basin is characterized by a wide (more than $200 \mathrm{~km}$ ) flat bathymetry (water depth averages $50 \mathrm{~m}$ ). In contrast, the southern coast has a narrow shelf (only a few km wide), with depths increasing abruptly from $100 \mathrm{~m}$ to $1500 \mathrm{~m}$ (Özsoy and Ünlüata, 1997; Kosarev and Kostianoy, 2008). The drainage area of the Black Sea is about $2.5 \times 10^{6} \mathrm{~km}^{2}$, with more than 500 rivers flowing into the basin (Mikhailov and Mikhailova, 2008). Of these, the three largest are the Danube, Dnieper, and Dniester, all of which enter at the north-western edge of the basin (Fig. 7). 


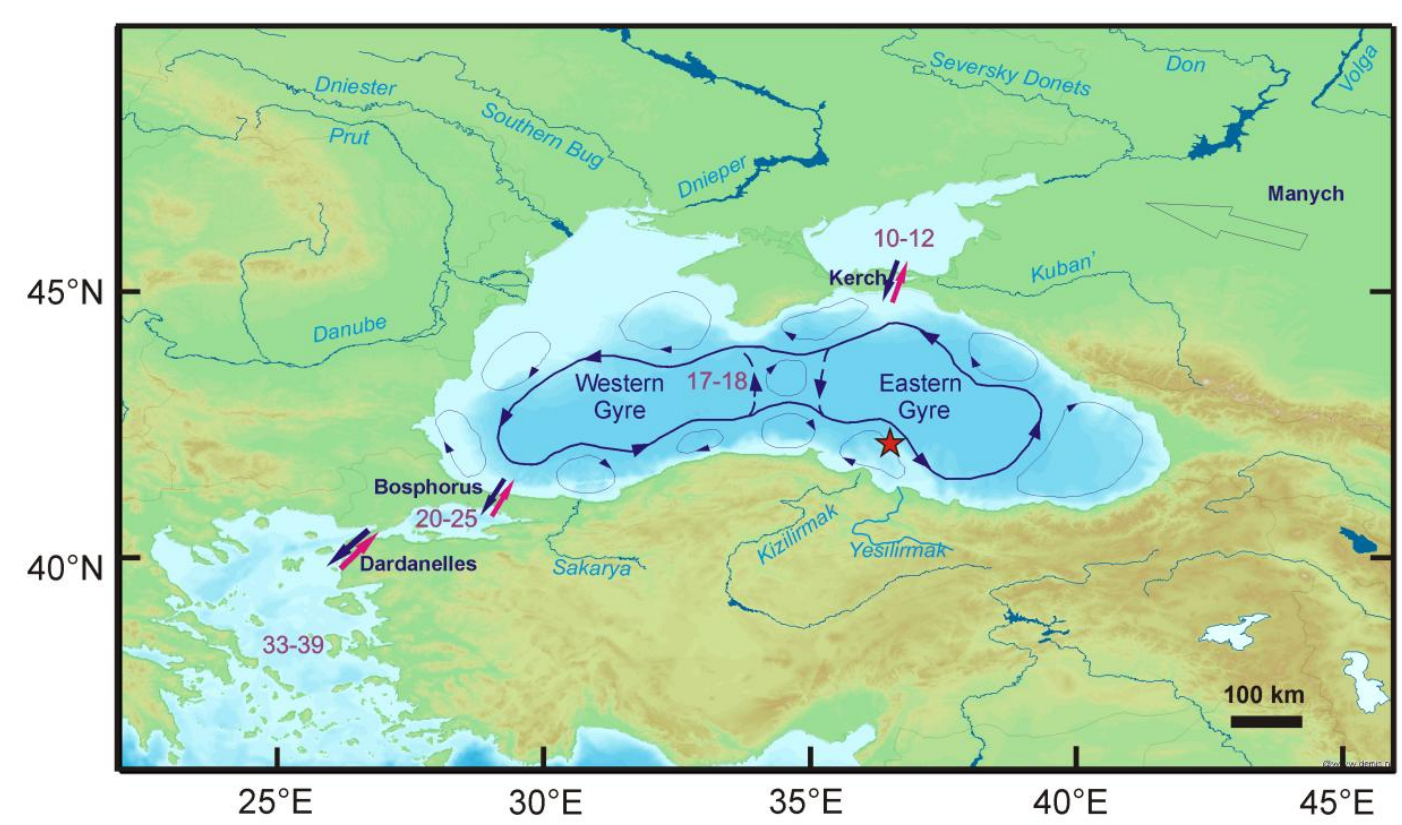

Fig. 7. Map of the Black Sea region showing the general surface water circulation system of the Black Sea (modified from Oguz et al., 1993) and main rivers and straits. Thick (blue) lines indicate the main water current with eastern and western gyres, and eddies are indicated by thin (blue) lines. Coloured arrows show direction of in and outflow currents through the Dardanelles, Bosphorus and Kerch straits: left (blue) for less salty surface water, right (purple) for deeper saltier water. Colourless arrow indicates previous connection to the Caspian Sea through Manych. Sea-surface salinities are given in purple numbers from Uçkaç (2005), Beşiktepe et al. (1994), Özsoy and Ünlüata (1997), Kosarev et al. (2008). The red star shows the location of cores 22-GC3/8. Map sources: www.bgr.de, www.nowcoast.noaa.gov, www2.demis.nl.

With a maximal water depth of $\sim 2200 \mathrm{~m}$, the Black Sea is the largest meromictic basin in the world with a permanent two-layered water structure (Özsoy and Ünlüata, 1997; Fig. 8). The upper 100-200 m thick layer has a sea-surface salinity (SSS) of $\sim 17-18$ due to river discharges, whereas the lower $2000 \mathrm{~m}$ thick layer has a SSS of 22.3 due to the inflow of Mediterranean waters via the Marmara Sea. Temperatures in the Black Sea are characterized by seasonal changes at the surface $\left(3.5-8^{\circ} \mathrm{C}\right.$ in winter and $23.5-25.5^{\circ} \mathrm{C}$ in summer), by the presence of a cold intermediate layer $\left(\mathrm{CIL}\right.$; temperature $\left.7.2^{\circ} \mathrm{C}\right)$, and by a relatively constant temperature in the deeper layers $\left(9.2^{\circ} \mathrm{C}\right)$ (Ginzburg et al., 2008; Tuzhilkin, 2008). The circulation system of the Black Sea surface water (Fig. 7) demonstrates a cyclonal rim gyre with mesoscale western and eastern gyres, and anticyclonal eddies along the coast (Oguz et al., 1993).

At present, the Black Sea has a positive water balance as precipitation $\left(\sim 300 \mathrm{~km}^{3} \mathrm{yr}^{-1}\right)$, river discharge $\left(\sim 350 \mathrm{~km}^{3} \mathrm{yr}^{-1}\right)$ and inflow of Mediterranean water $\left(\sim 300 \mathrm{~km}^{3} \mathrm{yr}^{-1}\right)$ surpass evaporation $\left(\sim 350 \mathrm{~km}^{3} \mathrm{yr}^{-1}\right)$ (Fig. 8). As a result, the outflow from the Black Sea through the Bosphorus into the Marmara Sea averages $\sim 600 \mathrm{~km}^{3} \mathrm{yr}^{-1}$ (Özsoy and Ünlüata, 1997). 


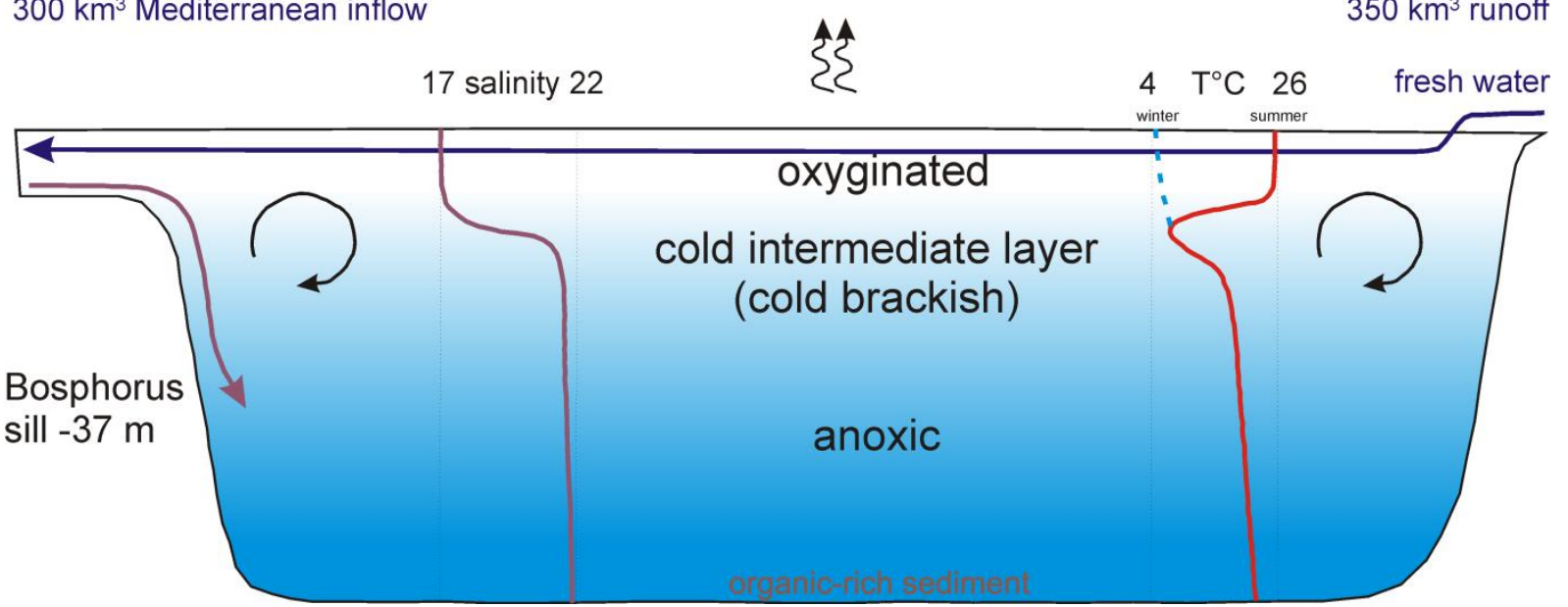

Fig. 8. Simplified profile of the Black Sea demonstrating its hydrological balance, temperature (winter and summer) and salinity gradients, oxygenated/anoxic layers and cold intermediate layer (based on Özsoy and Ünlüata, 1997).

The water exchange between the Black Sea and Marmara Sea occurs in two layers: a sub-surface inflow of Mediterranean and shallow outflow of Black Sea water. Warm (14.5 ${ }^{\circ} \mathrm{C}$ ), highly saline (37) Mediterranean waters enter the Black Sea basin through the Bosphorus Strait, with the flow following the relief of the shelf and mixing with the overlaying CIL, becoming colder $\left(9.2{ }^{\circ} \mathrm{C}\right)$ and less saline (22.3) and sinking along the continental slope (Özsoy and Ünlüata, 1997; Murray et al., 2005). Due to the permanent pycno- and haloclines, annual renewal of the water occurs only to a depth of approximately 60-80 m (e.g. Debol'skaya et al., 2007; Tuzhilkin, 2008); the water column below a depth of 100-200 m represents a hydrogen sulphide zone, in which only anoxic processes take place (Kosarev and Kostianoy, 2008), allowing good preservation of organic matter.

According to Yayla et al. (2001), light penetrates in the southern Black Sea into the upper 20-35 m. Under optimum light conditions, phytoplankton growth rate is governed by the concentration of essential nutrients (Yunev et al., 2002; Nezlin, 2008; Stel'makh et al., 2009), depending on the thermal stratification and mixing processes of the surface water. Intensive solar heating initiates surface water stratification in summer. The vertical mixing of summer stratified waters occurs mostly by CIL formation in winter, transporting heat and oxygen into the deeper water as well as nutrients upwards into the photic layer (Yunev et al., 2005). Eddy dynamics (Zatsepin et al., 2007) and upwelling along the Anatolian coast (e.g. Özsoy and Ünlüata, 1997) intensify mixing processes of the surface water in summer. 


\subsection{Climatology}

The climate of the Black Sea region is controlled by interactions of the Mediterranean, temperate European and continental Asian climate. In the summertime, the belt of moist westerly winds shifts northward and the Mediterranean high-pressure zone provides warm and dry air for the entire region from the Balkan Peninsula to central Anatolia in the east and as far as the Crimean Peninsula in the north. The summers are warm with mean July temperatures above $20^{\circ} \mathrm{C}$, except for the high-altitude mountain areas (Table 4). In winter, generally cold weather is caused by cold air masses from continental Asia controlled by the Siberian High. The mean January temperatures are around zero at low elevations, while the mountains and lowlands in the north experience temperatures below freezing (Table 4).

Table 4. Modern climate data from the meteorological stations (see Fig. 6 for the locations) situated around the Black Sea (after www.klimadiagramme.de).

\begin{tabular}{lccccccccc}
\hline \multirow{3}{*}{ Station } & \multicolumn{3}{c}{ Coordinates } & \multicolumn{3}{c}{ Mean Temperatures, ${ }^{\circ} \mathrm{C}$} & \multicolumn{3}{c}{ Precipitation, mm } \\
\cline { 2 - 10 } & $\begin{array}{c}\text { Latitude } \\
{ }^{\circ} \mathrm{N}\end{array}$ & $\begin{array}{c}\text { Longitude } \\
{ }^{\circ} \mathrm{E}\end{array}$ & $\begin{array}{c}\text { Altitude } \\
\text { m a.s.l. }\end{array}$ & July & January & Year & $\begin{array}{c}\text { Warm } \\
\text { (IV-IX) }\end{array}$ & $\begin{array}{c}\text { Cold } \\
(\mathrm{X}-\mathrm{III})\end{array}$ & Year \\
\hline 1. Ankara & $39^{\circ} 57^{\prime}$ & $32^{\circ} 53^{\prime}$ & 894 & 22.9 & 0 & 11.7 & 186 & 230 & 416 \\
2. Istanbul & $40^{\circ} 58^{\prime}$ & $29^{\circ} 05^{\prime}$ & 40 & 23.2 & 5.4 & 14.1 & 188 & 510 & 698 \\
3. Odessa & $46^{\circ} 29^{\prime}$ & $30^{\circ} 38^{\prime}$ & 64 & 21.5 & -1.5 & 10.2 & 235 & 234 & 469 \\
4. Rize & $41^{\circ} 02^{\prime}$ & $40^{\circ} 30^{\prime}$ & 140 & 22.2 & 6.3 & 13.9 & 870 & 1301 & 2171 \\
5. Rostov-on-Don & $47^{\circ} 15^{\prime}$ & $39^{\circ} 49^{\prime}$ & 77 & 23.1 & -4.6 & 9.6 & 289 & 290 & 579 \\
6. Samsun & $41^{\circ} 17^{\prime}$ & $36^{\circ} 20^{\prime}$ & 4 & 22.7 & 6.9 & 14.3 & 269 & 423 & 692 \\
7. Sochi & $43^{\circ} 35^{\prime}$ & $39^{\circ} 46^{\prime}$ & 34 & 22.7 & 5.9 & 14.0 & 642 & 931 & 1573 \\
8. Varna & $43^{\circ} 12^{\prime}$ & $27^{\circ} 55^{\prime}$ & 43 & 22.0 & 1.9 & 12.1 & 230 & 241 & 471 \\
9. Zonguldak & $41^{\circ} 27^{\prime}$ & $31^{\circ} 48^{\prime}$ & 136 & 21.5 & 6.0 & 13.6 & 435 & 759 & 1194 \\
\hline
\end{tabular}

In the northern part of the Black Sea region, total amounts of precipitation do not exceed $600 \mathrm{~mm} / \mathrm{yr}$ in the low-elevation zone, whereas the north-west-oriented slopes of the Pontic Mountains and Caucasus may receive up to $1000-2500 \mathrm{~mm} / \mathrm{yr}$ (Table 4). The lowpressure cells from the Atlantic Ocean shift southwads of their summer position and bring moisture to the southern part of the Mediterranean region (Alpat'ev et al, 1976). The relatively warm waters of the Mediterranean Sea serve as a secondary moisture source, which allows storm tracks to renew their strength as they move eastward (Dobrovolskiy and Zalogin, 1982; Roberts and Wright, 1993; Kosarev and Kostianoy, 2008). The mean annual rainfall decreases rapidly along the Anatolian coast of the Black Sea towards the interior of Turkey, where generally arid to semi-arid regions prevail (Mayer and Askoy, 1986; Table 4). 


\subsection{Vegetation}

Climatic controls, amplified by local topography, play a dominant role in determining the pattern of natural vegetation in the Black Sea region. Relatively detailed maps, showing vegetation patterns in Europe and Asia around the Black Sea, are provided in the World Atlas (Gerasimov, 1964) and in a number of regional publications (e.g. Louis, 1939; Zohary, 1973; Alpat'ev et al., 1976; Quézel and Barbéro, 1985; Mayer and Aksoy, 1986; Frey and Kürschner, 1989; Kürschner, 1997). The main vegetation types, shown on the large-scale maps (Gerasimov, 1964) include different types of conifer and temperate deciduous forests, as well as sub-Mediterranean and Mediterranean forests, woodlands and shrublands, Artemisiadominated steppes on the Anatolian plateau and north of the Black Sea, and alpine meadows in the high mountains (Fig. 9).

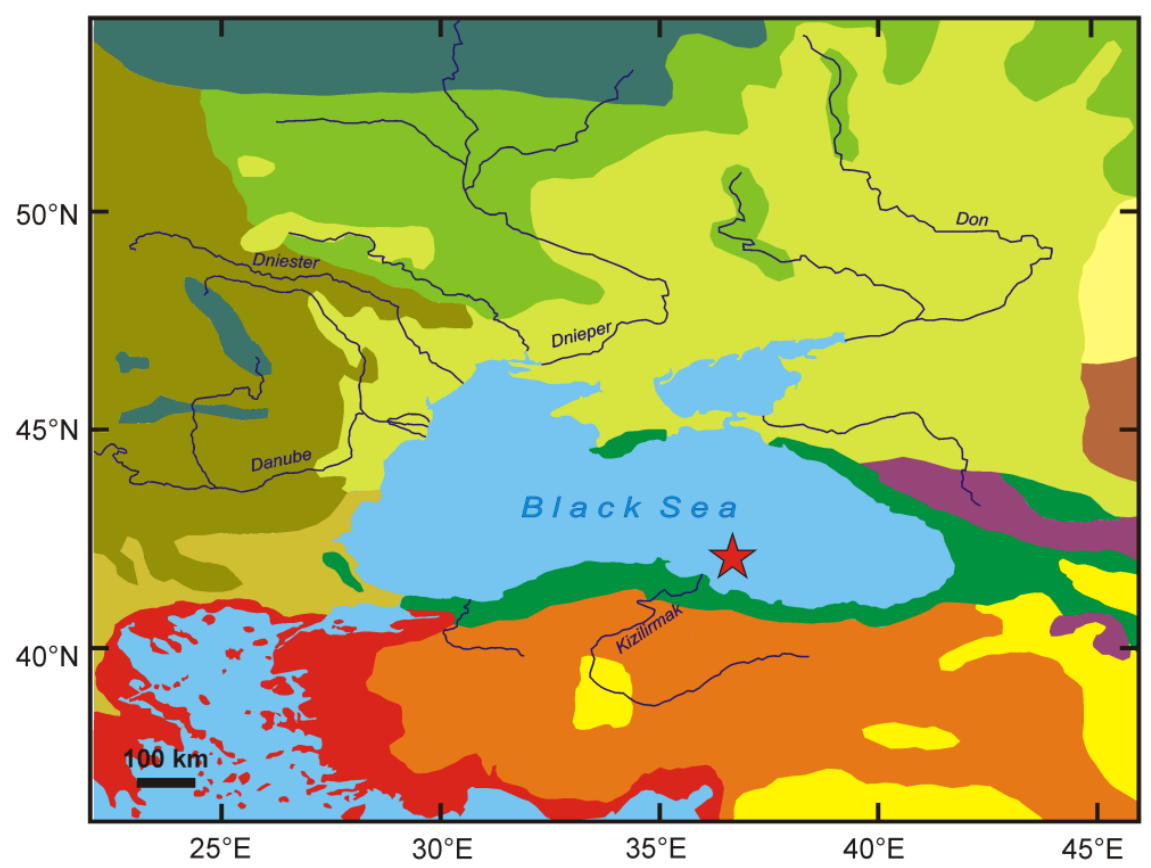

\section{Legend:}

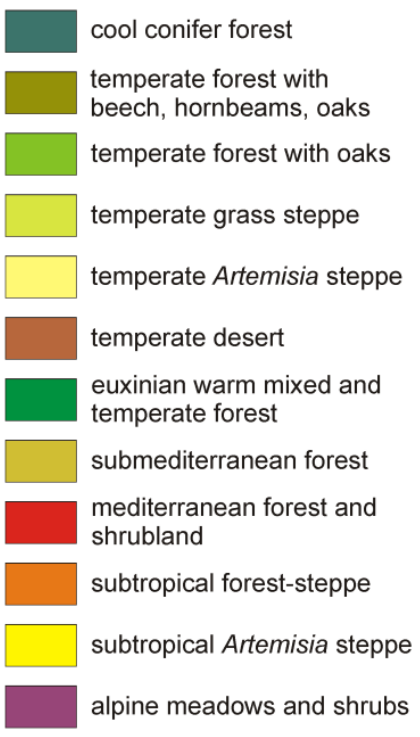

Fig. 9. Map of the Black Sea region showing key vegetation types (modified from Gerasimov, 1964; Zohary, 1973) and location of studied cores 22-GC3/8 and 25-GC1 (red star).

In addition to the regional vegetation distribution map (Fig. 9), Figure 10 presents a simplified vegetation profile across the Pontic Mountains (Mayer and Aksoy, 1986; Kürschner, 1997). As northern Anatolia with the Pontic Mountains is located nearest to the study site (Fig. 6), it should be considered as a major pollen source area for the core sediments, considering wind patterns, river input and gyre systems in the Black Sea. High plant diversity in Turkey, whose flora contains about 8500 species, is explained by an interaction of climate and topography (Kürschner, 1997). 
Indicative for the whole Eu-Euxinian territory (wet forests of Pontus Mountains and Caucasus; Zohary, 1973), Fagus orientalis associates more frequently at lower altitudes (0$800 \mathrm{~m}$ ) with various deciduous trees such as Carpinus betulus, Castanea sativa, Tilia rubra, Acer insigne, Alnus barbara, Corylus, deciduous Quercus species etc. Mixed forests with evergreen shrubs (Rhododendron ponticum, Ilex aquifolium, I. colchica, Daphne pontica, Buxus sempervirens, Prunus laurocerasus) and lianas (Smilax excelsa, Hedera helix, H. colchica, Clematis spec., Vitis vinifera, V. silvestris) presents a kolchic character (Zohary, 1973; Mayer and Aksoy, 1986). Along the Black Sea coast, Nowack and Markgraf (1928), Nowack (1931), Louis (1939), and Zohary (1973) indicated a series of scattered macchia shrublands (Phillyrea media, Laurus nobilis, Cistus creticus, Juniperus oxycedrus, Erica arborea, Myrthus communis, Arbutus andrachne) inhabiting hot and dry habitats, unfavorable to local temperate vegetation, such as sandy soil or rocky outcrops, or sites with destroyed original summer-green vegetation. At higher elevations ( 800-1500 m a.s.1.), pure beech $(F$. orientalis) or hornbeam-beech (Carpinus-Fagus) forests predominate, demonstrating a central European character. Higher altitudes (above $\sim 1500 \mathrm{~m}$ ) in the western part of the mountains are occupied by fir (Abies nordmanniana ssp. bornmuelleriana) and in the eastern part by fir (A. nordmanniana ssp. nordmanniana) and spruce (Picea orientalis) forests (Zohary, 1973; Mayer and Aksoy, 1986). The lack of high mountains (i.e. above $1500 \mathrm{~m}$ ) explains the dominance of pure Fagus forests and absence of Abies in the central part of the Northern Anatolia. Grasslands dominate in the subalpine and alpine mountain belt above $2000 \mathrm{~m}$ a.s.l.

The southeast mountain slopes facing the Anatolian Plateau are covered with drier vegetation types, including open woodland dominated by eurythermic conifers (e.g. Pinus nigra, Juniperus excelsa, J. oxycedrus) and deciduous oaks (Quercus pubescens, Q. trojana). Above 2000 m elevation, subalpine thorny shrubs (Astracanthus spec., Sarcopoterium spec.) are characteristic. Mediterranean elements were also found in Çoruh valley by Artvin (Punica granatum, Ficus carica, A. andrachne, Diospyros lotus, Olea europea) and at the southern part of Pontic Mountains (Pinus brutia, Quercus ithaburensis, Juniperus excelsa, Pistacia atlantica, Cedrus libani). Krause (1929), Louis (1939), Mayer and Aksoy (1986) denominate these elements as relict vegetation. The zone of steppe forest (Zohary, 1973) occupies a broad belt to the south from the Pontic Mountains. It is represented by Querco-Artemisietea anatolica associations (Quercus pubescens) and connected by the Tuz Lake with central Anatolian dwarf-shrub steppes of Artemisietea fragrantis. On the border between forest steppe and steppe, juniper species grow (e.g. Juniperus excelsa, J. oxycedrus). 


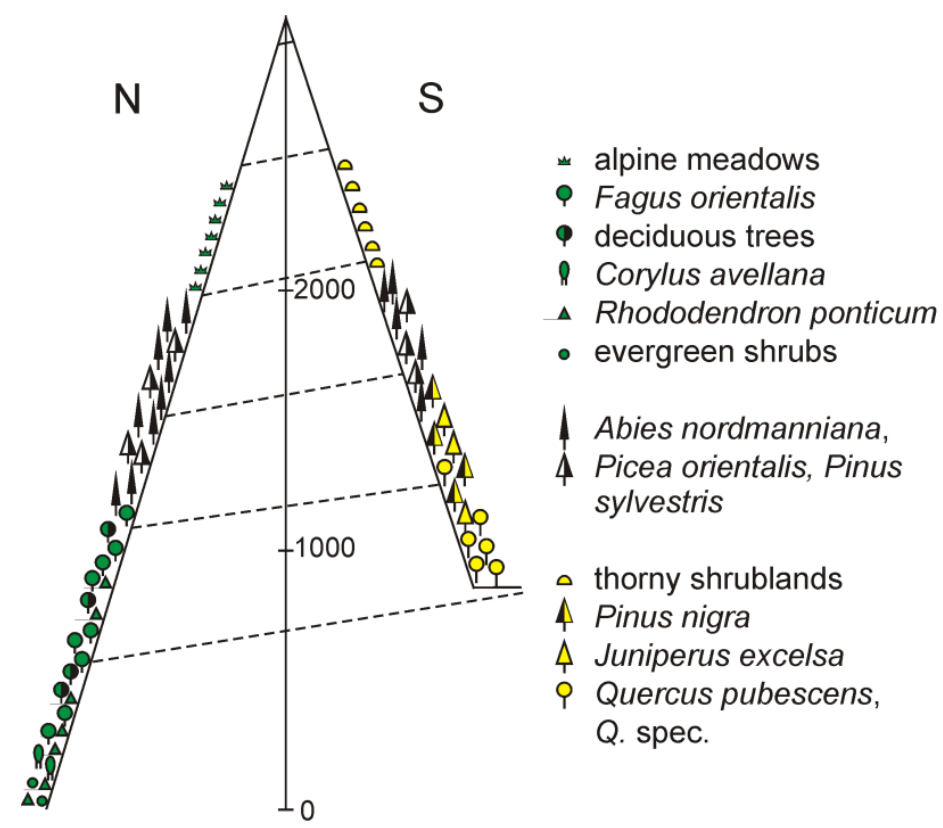

Fig. 10. Simplified vegetation profile across the Pontic Mountains (modified from Mayer and Aksoy, 1986; Kürschner, 1997).

At present, disturbance caused by intensive land use, including logging, livestock breeding and agriculture, have led to the patchy character of the woody vegetation, which is mainly preserved in the mountains and protected areas. Hazel (Corylus) and other fruit trees are cultivated in the western and central part of Northern Anatolia from Istanbul to Trabzon, whereas tea grows in the wettest and warmest eastern part and the cultivation of cereals is more typical of inner Anatolia (e.g. Mayer and Aksoy, 1986).

\section{Material and methods}

5.1. Pollen, spores and non-pollen palynomorph analysis

Subsamples from sediment cores 22-GC3, 22-GC8 and 25-GC1 were taken for palynological analysis on 1-8 cm intervals. Samples, consisting of $1 \mathrm{~cm}^{3}$ of wet sediment, were prepared using standard methods (Erdtman, 1960; Moore et al., 1999). We added one or two tablets of Lycopodium spores (Batch No 177745, consist of $18584 \pm 354$ spores) to each sample in order to calculate grain concentrations (Stockmarr, 1971). The laboratory procedures included treatment in cold $10 \% \mathrm{HCl}$ to remove carbonates, sieving through a metallic sieve with $150 \mu \mathrm{m}$ mesh size to remove coarse sediment particles, treatment in cold 71-74\% HF over two nights to remove silica minerals, acetolysis (three minutes) to destroy remaining soluble organic tissues, and an ultrasonic bath (nylon sieve of 1-2 $\mu \mathrm{m}$ mesh size) for the final cleaning. The remaining suspensions stored in glycerine were then used for microscopic analysis. Routine counting was carried out at $400 \times$, and in ambiguous cases at 
$1000 \times$ magnification. The pollen reference collections of the Department of Palynology and Climate Dynamics at Georg-August University in Göttingen (Germany) were used for the identification of pollen and spores. We followed the pollen and spore nomenclature of Beug (2004) and Chester and Raine (2001). Fungal spores were identified using Kuprevich and Ul'yanishchev (1975) for rusts, Vanky (1994) for smut fungi, Bell (2005) and Doveri (2007) for coprophilous fungi. Other NPPs were named following van Geel et al. (1989, 2003). Pollen sum for calculation of percentages include a minimum of 300-350 identified and counted pollen grains per sample. The diagrams were constructed using the software C2 (version 1.6.6) (Juggins, 2003).

The diagrams were subdivided into local zones, which were established visually by comparing dynamics of the principal taxa, supported by the results of biome score calculation. For purpose of biome reconstructions we assign pollen taxa to plant functional types and, based on the plant functional types contributing to each biome, classified pollen spectra to biomes following method presented by Prentice et al. (1992, 1996).

\subsection{Organic-walled dinoflagellate cyst analysis}

For dinoflagellate cyst analysis, subsamples of $0.5-1 \mathrm{~cm}^{3}$ were collected from cores $22-$ GC3 and 22-GC8 at 1-2 cm intervals. The samples were oven dried $\left(60^{\circ} \mathrm{C}\right)$ for one night and prepared using standard methods without acetolysis and ultra-sonic bath treatment. The procedure included demineralisation with cold $\mathrm{HCl}(10 \%)$, followed by cold $\mathrm{HF}(70 \%)$ over two nights and sieving at $10 \mu \mathrm{m}$ on a nylon mesh. To calculate the cyst concentration, one or two tablets of Lycopodium spores (batch number 177745; consists of $18584 \pm 371$ spores) were added to each sample at the beginning of the preparation. Identifications were carried out under x400 magnification. Dinoflagellate cyst taxonomy is based on Wall et al. (1973), Rochon et al. (1999) and Marret et al. (2004). The calculation of dinocyst percentages is based on the total sum of identified organic-walled dinoflagellate cysts per sample (308 \pm 9$)$. In addition to dinocysts, other algae and common marine acritarchs and non-pollen palynomorphs (NPP) (e.g. Botryococcus, Cymatiosphaera sp., Pterospermella) were counted (Mudie et al., 2011) and expressed as percentages of the dinocyst sum. The diagrams were designed using the software C2 data analysis Version 1.6.6 (Juggins, 2003). Based on the important changes in the relative abundance of dinocyst key species, diagrams were divided into local zones.

For the semi-qualitative reconstruction of hydrological changes at the core site, taxa percentages were summed into several groups according to their modern distribution and 
ecological preferences (e.g. Marret and Zonneveld, 2003; Marret et al., 2004). The "thermophilic" group includes cysts with subtropical / tropical distribution (Tuberculodinium vancampoae, Spiniferites pachydermus, Spiniferites mirabilis, Tectatodinium pellitum, cysts of Polykrikos schwartzii, and cysts of Protoperidinium stellatum). "Fully marine" taxa include dinocysts occurring at SSS >28.5 (Spiniferites pachydermus, Spiniferites mirabilis, Bitectatodinium tepikiense, Tectatodinium pellitum, Ataxiodinium choane, and cysts of Polykrikos schwartzii, Spiniferites bentorii, Xandarodinium xanthum).

\section{Outline of manuscripts and description of personal contribution}

The main part of this thesis consists of three manuscripts, published or submitted to peer-reviewed international journals, as well as one manuscript in preparation and one study with preliminary results. Formatting of manuscripts is presented as required by different journals. Complete pollen diagrams are presented in the appendices 1-4.

The first manuscript "Vegetation and environmental dynamics in the southern Black Sea region since 18 kyr BP derived from the marine core 22-GC3" (L.S. Shumilovskikh, P. Tarasov, H.W. Arz, D. Fleitmann, F. Marret, N. Nowaczyk, B. Plessen, F. Schlütz, H. Behling; Palaeogeography, Palaeoclimatology, Palaeoecology (2012) 337-338, 177-193) presents the first continuous high-resolution pollen record (core 22-GC3) from the SE Black Sea since the late-glacial. Vegetation changes in Northern Anatolia are compared with the dinocyst record and other multi-proxy data from the core and discussed with special emphasis on Northern hemisphere climate dynamics as well as anthropogenic impact. Personal contribution includes subsampling and laboratory preparation of sediments, microscopic analysis (identification and counting) of pollen, fern/moss spores, fungal spores, dinocysts and NPP, analysis of results, preparation of all Figures and Tables except Fig. 4, Table 3 and 4 and their description in section 3.1, as well as writing and revision of the manuscript for publication.

The second manuscript "Eemian and Holocene sea-surface conditions in the southern Black Sea: organic-walled dinoflagellate cyst record from core 22-GC3" (L.S. Shumilovskikh, F. Marret, D. Fleitmann, H.W. Arz, N. Nowaczyk, H. Behling; Marine Micropaleontology, in revision) deals with the dynamics of sea-surface conditions of the Black Sea during the last interglacial in comparison to the Holocene. Palaeoenvironmental reconstructions, based on dinocyst records from core 22-GC3, are compared with regional records and discussed in a supra-regional context. Subsampling and further laboratory preparation, microscopic analysis (identification and counting) and making microphotographs 
of dinocysts and NPP, analysis of results, working on the age-depth model of the Eemian interval, preparation of all Figures and Tables except Fig. 3 and 4, Table 2 and partly 1 and their description section 3.1, as well as writing and revision of the manuscript for publication were performed by myself.

The third manuscript "Vegetation and environmental changes in Northern Anatolia during penultimate deglaciation and Eemian recorded in Black Sea sediments" (L.S. Shumilovskikh, H.W. Arz, D. Fleitmann, F. Marret, N. Nowaczyk, P. Tarasov, A. Wegwerth, H. Behling; Quaternary Research, in review) continues the presentation of pollen investigations and presents the first detailed record for Northern Anatolia from core 22-GC3/8 during 134-119 ka BP. In combination with data presented in the two other previous publications, it highlights the vegetation and climatic dynamics of the region during the penultimate glacial-interglacial transition and the Eemian. An important part of the manuscript deals with the question of geographical patterns of beech distribution during the last interglacial. My personal contribution includes subsampling and further laboratory preparation, microscopic analysis (identification and counting) of pollen, fern/moss spores, fungal spores, dinocysts and NPP, working on the age-depth model of the Eemian interval, analysis of results, preparation of all Figures and Tables except Fig. 3, partly Table 2 and their description in the section Age-depth model, as well as writing of the manuscript.

The main goal of the fourth manuscript "Millennial-scale environmental variability during the last glacial detected in pollen and dinocyst records from the SE Black Sea" (L.S. Shumilovskikh, H. Arz, N. Nowaczyk, D. Fleitmann, A. Wegwerth, H. Behling; supposed to be submitted to Quaternary Science Reviews) is to provide an analysis of vegetation and seasurface reactions to the abrupt changes during the last glacial cycle. This analysis is based on pollen and dinocyst records from core $25-\mathrm{GC} 1$ covering the period of $64-25 \mathrm{ka}$. The manuscript includes additional comparison with other proxies from the same core. Subsampling and further laboratory preparation, microscopic analysis (identification and counting) of pollen, fern/moss spores, fungal spores, dinocysts and NPP, analysis of results, preparation of all Figures except Fig. 2, as well as writing of the manuscript were performed by myself.

The fifth manuscript "Recent pollen distribution in Northern Anatolia and SE Black Sea: preliminary results" (L.S. Shumilovskikh, F. Schlütz, H. Behling; ongoing study) presents the first results of the ongoing study on surface samples from Northern Anatolia. This study aims to define the pollen source area for the studied core 22-GC3 by comparison of pollen spectra from the surface of the Black Sea sediments with pollen spectra from the 
adjacent land. Collection of surface samples in Turkey, preparation, microscopic analysis (identification and counting) of pollen and spores, analysis of results, preparation of all Figures and Tables and writing of the manuscript were done personally by myself.

\section{References}

Alpat'ev, A.M., Arkhangel'skii, A.M., Podoplelov, N.Y., Stepanov, A.Y., 1976. Fizicheskaya geografiya SSSR (Evropeiskaya chast'). Vysshaya Shkola, Moscow (in Russian).

Andrusov, N.I., 1890. Predvaritel'niy otchet ob uchastii s Chernomorskoy glubokomernoy ekspeditsii. Izvestiya Russkogo Geographicheskogo obshchestva 26, 380-409 (in Russian).

Arkhangel'skii, A.D., Strakhov, N.M., 1938. Geologicheskoe stroenie i istoriya pazvitiya Chernogo moria. Izdatel'stvo Akademii Nauk, Moskva (in Russian).

Arslanov, Kh.A., Dolukhanov, P.M., Gei, N.A., 2007. Climate, Black Sea levels and human settlements in Caucasus Littoral 50,000-9000 BP. Quaternary International 167-168, 121-127.

Atanassova, 2005. Palaeoecological setting of the western Black Sea during the last 15000 years. The Holocene 15, 576-584.

Atanassova, J.R., Božilova, E.D., 1992. Palynological investication of marine sediments from the western sector of the Black Sea. Oceanology 1, 97-103.

Aytuğ, B., Merev, N., Edis, G., 1975. Sürmene - Ağaçbaşı dolayları Lâdin ormanının tarihi ve geleceği. Tarim ve Ormancılık Araştırma Grubu, 64 p (in Turkish).

Badertscher, S., Fleitmann, D., Cheng, H., Edwards, R.L., Göktürk, O.M., Zumbühl, A., Leuenberger, M., Tüysüz, O., 2011. Pleistocene water intrusions from the Mediterranean and Caspian Seas into the Black Sea. Nature Geoscience, DOI: 10.1038/NGEO1106.

Bahr, A., Lamy, F., Arz, H.W., Kuhlmann, H., Wefer, G., 2005. Late glacial to Holocene climate and sedimentation history in the NW Black Sea. Marine Geology 214, 309-322.

Bahr, A., Arz, H.W., Lamy, F., Wefer, G., 2006. Late glacial to Holocene paleoenvironmental evolution of the Black Sea, reconstructed with stable oxygen isotope records obtained on ostracod shells. Earth and Planetary Science Letters 241, 863-875.

Bahr, A., Lamy, F., Arz, H.W., Major, C., Kwiecien, O., Wefer, G., 2008. Abrupt changes of temperature and water chemistry in the late Pleistocene and early Holocene Black Sea, Geochem. Geophys. Geosyst., 9, Q01004, doi:10.1029/2007GC001683. 
Bartov, Y., Goldstein, S.L., Stein, M., Enzel, Y., 2003. Catastrophic arid episodes in the Eastern Mediterranean linked with North Atlantic Heinrich events. Geology 31, 439442 .

Bell, A., 2005. An illustrated guide to the coprophilous Ascomycetes of Australia. Centraalbureau voor Schimmelcultures, Utrecht.

Beşiktepe, Ş.T., Sur, H.I., Özsoy, E., Latıf, M.A., Oğuz, T., Ünlüata, Ü., 1994. The circulation and hydrography of the Marmara Sea. Progress in Oceanography 34, 285-334.

Beug, H.-J., 1967. Contributions to the postglacial vegetational history of Northern Turkey. Quaternary Paleoecology 7, 349-356.

Beug, H.-J., 2004. Leitfaden der Pollenbestimmung für Mitteleuropa und angrenzende Gebiete. Pfeil, München (in German).

Björkman, L., Feurdean, A., Cinthio, K., Wohlfarth, B., Possnert, G., 2002. Lateglacial and early Holocene vegetation development in the Gutaiului Mountains, northwestern Romania. Quaternary Science Review 21, 1039-1059.

Björkman, L., Feurdean, A., Wohlfarth, B., 2003. Late-Glacial and Holocene forest dymanics at Steregoiu in the Gutaiului Mountains, Northwest Romania. Review of Palaeobotany and Palynology 124, 79-111.

Bond, G., Lotti, R., 1995. Iceberg Discharges into the North Atlantic on Millenial Time Scales During the Last Glaciation. Science 267, 1005-1010.

Bond, G., Broecker, W., Johnsen, S., McManus, J., Labeyrie, L., Jouzel, J., Bonani, G., 1993. Correlations between climate records from North Atlantic sediments and Greenland ice. Nature 365, 143-147.

Bottema, S., 1995. Holocene vegetation of the Van area: palynological and chronological evidence from Sögütlü, Turkey. Vegetation History and Archaeobotany 4, 187-193.

Bottema, S., Woldring, H., 1984. Late Quaternary vegetation and climate of southwestern Turkey. Part II. Palaeohistoria 26, 123-149.

Bottema, S., Woldring, H., 1995a. The prehistoric environment of the lake Iznik area: a palynological study. In: Roodenberg, J. The Ilıpınar excavations I: five seasons of fieldwork in NW Anatolia, 1987-91. Nederlands historisch-archaeologisch instituut, Istanbul. Pp. 8-16.

Bottema, S., Woldring, H., 1995b. The environment of classical Sagalassos: a palynological investigation, in: Waelkens, M., Poblome, J. (Eds.), Sagalassos III. Report on the Fourth Excavation Campaign of 1993. Leuven University Press, Leuven, pp. 327-340. 
Bottema, S., Woldring, H., Aytuğ, B., 1995. Late Quaternary vegetation of Northern Turkey. Palaeohistoria 35/36, 13-72.

Božilova, E.D., 1975. Changes of vegetation belts in Rila mountains during late and post Glacial time. Bulletin of Geology 19, 93-99.

Božilova, E., Beug, H.-J., 1992. On the Holocene history of vegetation in Se Bulgaria (Lake Arkutino, Ropotamo region). Vegetation history and Archaeobotany 1, 19-32.

Božilova, E., Beug, H.-J., 1994. Studies on the vegetation history of Lake Varna region, northern Black Sea coastal area of Bulgaria. Vegetation History and Archaeobotany 3, 143-154.

Božilova, E., Djankova, M., 1976. Vegetation development during the Eemian in the North Black Sea Region. Phytology 4, 25-32.

Božilova, E., Filipova, M., Atanasova, J., 1992. Marine palynological data about palaeoecological conditions and vegetation history of eastern Bulgaria during the last 15000 years. Annuaire de l'universite de sofia "St. Kliment Ohridski”, Livre 2 Botanique 82, 79-87.

Buynevich, I.V., Yanko-Hombach, V., Gilbert, A.S., Martin, R.E. (Eds.), 2011. Geology and Geoarchaeology of the Black Sea Region: beyond the flood hypothesis. The Geological Society of America, Boulder, USA.

Cacho, I., Grimalt, J.O., Sierro, F.J., Shackleton, N., Canals, M., 2000. Evidence for enhanced Mediterranean thermohaline circulation during rapid climatic coolings. Earth and Planetary Science Letters 183, 417-429.

Cacho, I., Grimalt, J.O., Canals, M., Sbaffi, L., Shackleton, N., Schönfeld, J., Zahn, R., 2001. Variability of the western Mediterranean Sea surface temperature during the last 25,000 years and its connection with Northern Hemisphere climatic changes. Paleoceanography $16,40-52$.

Cacho, I., Grimalt, J.O., Canals, M., 2002. Response of the Western Mediterranean Sea to rapid climatic variability during the last 50,000 years: a molecular biomarker approach. Journal of Marine Systems 33-34, 253-272.

Cheddadi, R., Rossignol-Strick, M., 1995. Eastern Mediterranean Quaternary paleoclimates from pollen and isotope records of marine cores in the Nile Cone Area. Paleoceanography 10, 291-300.

Chester, P.I., Raine, J.I., 2001. Pollen and spore keys for Quaternary deposits in the northern Pindos Mountains, Greece. Grana 40, 299-387. 
Combourieu-Nebout, N., Turon, J.L., Zahn, R., Capotondi, L., Londeix, L., Pahnke, K., 2002. Enhanced aridity and atmospheric high-pressure stability over the western Mediterranean during the North Atlantic cold events of the past 50 k.y. Geology 30, 863-866.

Connor, S.E., Thomas, I., Kvavadze, E.V., 2007. A 5600-yr history of changing vegetation, sea levels and human impacts from the Black Sea coast of Georgia. The Holocene 17, 25-36.

Cuffey, K.M., Marshall, S.J., 2000. Substantial contribution to sea-level rise during the last interglacial from the Greenland ice sheet. Nature 404, 591-594.

Dansgaard, W., Johnsen, S., Clausen, H.B., Dahl-Jensen, D., Gundestrup, N.S., Hammer, C.U., Hyidberg, C.S., Steffensen, J., Sveinbjörnsdottir, A.E., Jouzel, J., Bond, G., 1993. Evidence for general instability of past climate from a 250-kyr ice-core record. Nature 364, 218-220.

Debol'skaya, E.I., Yakushev, E.V., Kuznetsov, I.S., 2007. Estimating the Characteristics of the Vertical Turbulent Viscosity in the Upper 200-m Layer of the Black Sea. Oceanology 47 (4), 476-481.

Djamali, M., de Beaulieu, J.-L., Shah-hosseini, M., Andrieu-Ponel, V., Ponel, P., Amini, A., Akhani, H., Leroy, S.A.G., Stevens, L., Lahijani, H., Brewer, S., 2008. A late Pleistocene long pollen record from Urmia, NW Iran. Quaternary Research 69, 413-420.

Dobrovolskiy, A.D., Zalogin, B.S., 1982. Moria SSSR. Moscow State University, Moscow (in Russian).

Doveri, F., 2007. Fungi fimicoli Italici. A.M.B., Vicenza.

Eastwood, W.J., Leng, M.J., Roberts, N., Davis, B., 2007. Holocene climate change in the eastern Mediterranean region: a comparison of stable isotope and pollen data from Lake Gölhisar, southwest Turkey. Journal of Quaternary Science 22 (4), 327-341.

Erdtman, G., 1960. The acetolysis method. Svensk Botanisk Tidskrift 54, 561-564.

Fedorov, P.V., 1978. Pleistocene Ponto-Kaspiya. Nauka, Moskva (in Russian).

Feurdean, A., 2005. Holocene forest dynamics in northwestern Romania. The Holocene 15, 435-446.

Feurdean, A.N., Willis, K.J., Astalos, C., 2009. Legacy oft he past land-use changes and management on the 'natural upland forest composition in the Apuseni Natural Park, Romania. The Holocene 19, 967-981. 
Filipova, M.V., Božilova, E.D., Dimitrov, P.S., 1983. Palynological and stratigraphical data about the Quaternary from the Southern part of the Bulgarian Black Sea shelf. Okeanologija 11, 24-32.

Filipova-Marinova, M., 2006. Palynostratigraphy of pleistocene and holocene sediments from the western Black Sea. JEMMM 3, 91-113.

Fletcher, W.J., Sánchez-Goñi, M.F., Allen, J.R.M., Cheddadi, R., Combourieu-Nebout, N., Huntley, B., Lawson, I., Londeix, L., Magri, D., Margari, V., Müller, U., Naughton, F., Novenko, E., Roucoux, K., Tzedakis, P., 2010. Millennial-scale variability during the last glacial in vegetation records from Europe. Quaternary Science Reviews 29, 28392864.

Frey, W., Kürschner, H., 1989. Vorderer Orient. Vegetation 1:8 000000 (Karte A VI I Tübinger Atlas des Vorderen Orients). Dr. Ludwig Reichert, Wiesbaden (in German).

Gerasimov, I.P. (Ed.), 1964. Atlas Mira. AN SSSR-GUGK SSSR, Moscow (in Russian).

Ginzburg, A.I., Kostianoy, A.G., Sheremet, N.A., 2008. Sea Surface Temperature Varability. In: Kostianoy, G., Kosarev, A.N. (Eds.), The Handbook of Environmental Chemistry: Vol.5, Part Q: The Black Sea Environment. Springer Verlag, Berlin - Heidelberg, pp. 255-275.

Gogichaishvili, L.K., 1962. K istorii lesov Gare-Kakheti v Golotsene. Soobshcheniia Akademii Nauk Gruzinskoi SSR 29, 441-448 (in Russian).

Grootes, P.M., Stuiver, M., White, J.W.C., Johnsen, S., Jouzel, J., 1993. Comparison of oxygen isotope records from the GISP2 and GRIP Greenland ice cores. Nature 366, 552-554.

Hederl, G.C., Russon, T., 2011. Using the Past to Predict the Future? Science 334, 1360-1361. Heinrich, 1988. Origin and Consequences of Cyclic Ice Rafting in the Northeast Atlantic Ocean during the past 130,000 Years. Quaternary Research 29, 142-152.

Hemming, S.R., 2004. Heinrich events: massive late Pleistocene detritus layers of the North Atlantic and their global climate imprint. Review of Geophysics 42, doi:10.1029/2003RG000128.

Jansen, E., Overpeck, J., Briffa, K.R., Duplessy, J.-C., Joos, F., Masson-Delmotte, V., Olago, D., Otto-Bliesner, B., Peltier, W.R., Rahmstorf, S., Ramesh, R., Raynaud, D., Rind, D., Solomina, O., Villalba, R., Zhang, D., 2007. Palaeoclimate. In: Solomon, S., D. Qin, M. Manning, Z. Chen, M. Marquis, K.B. Averyt, M. Tignor and H.L. Miller (eds.) Climate Change 2007: The Physical Science Basis. Contribution of Working Group I to the 
Fourth Assessment Report of the Intergovernmental Panel on Climate Change. Cambridge University Press, Cambridge, United Kingdom and New York, NY, USA.

Juggins, S., 2003. C2 User Guide. Software for Ecological and Palaeoecological Data Analysis and Visualisation. University of Newcastle, Newcastle upon Tyne.

Kaniewski, D., de Laet, V., Paulissen, E., Waelkens, M., 2007. Long-term effects of human impact on mountainous ecosystems, western Taurus Mountains, Turkey. Journal of Biogeography 34, 1975-1997.

Knipping, M., Müllenhoff, M., Brückner, H., 2008. Human induced landscape changes around Bafa Gölü (western Turkey). Vegetation History and Archaeobotany 17, 365380.

Koreneva, E.V., Kartashova, G.G., 1978. Palynological study of samples from holes 379A, 380A, LEG 42B. In: Ross, D.A., Neprochnov, Y.P., et al. (eds.) Initial reports of the Deep Sea Drilling Project. U.S. Government Printing Office, Washington, pp. 951-992. Kosarev, A.N., Kostianoy, A.G., 2008. Introduction. In: Kostianoy, G., Kosarev, A.N. (Eds.),

The Handbook of Environmental Chemistry: Vol.5, Part Q: The Black Sea Environment. Springer Verlag, Berlin - Heidelberg, pp. 1-10.

Kosarev, A.N., Kostianoy, A.G., Shiganova, T.A., 2008. The Sea of Azov. In: Kostianoy, G., Kosarev, A.N. (Eds.), The Handbook of Environmental Chemistry: Vol.5, Part Q: The Black Sea Environment. Springer Verlag, Berlin - Heidelberg, pp.63-89.

Kotthoff, U., Müller, U.C., Pross, J., Schmiedl, G., Lawson, I.T., Schootbrugge, B. van de, Schulz, H., 2008. Lateglacial and Holocene vegetation dynamics in the Aegean region: an integrated view based on pollen data from marine and terrestrial archives. The Holocene 18, 1019-1032.

Krause, 1929. Zur pflanzengeographischen Gliederung Kleinasiens. Di Naturwissenschaften 22, 402-405 (in German).

Kremenetski, C.V., 1995. Holocene vegetation and climate history of southwestern Ukraine. Review of Palaeobotany and Palynology 85, 289-301.

Kremenetski, C.V., Chichagova, O.A., Shishlina, N.I., 1999. Palaeoecological evidence for Holocene vegetation, climate and land-use change in the low Don basin and Kalmuk area, southern Russia. Vegetation History and Palaeobotany 8, 233-246.

Kukla, G.J., Bender, M.L., de Beaulieu, J.-L., Bond, G., Broecker, W.S., Cleveringa, P., Gavin, J.E., Herbert, T.D., Imbrie, J., Jouzel, J., Keigwin, L.D., Knudsen, K.-L., McManus, J.F., Merkt, J., Muhs, D.R., Müller, H., Poore, R.Z., Porter, S.C., Seret, G., 
Shackleton, N.J., Turner, C., Tzedakis, P.C., Winograd, I.J., 2002. Last Interglacial

Climates. Quaternary Research 58, 2-13.

Kuprevich, V.F., Ul'yanishchev, V.I., 1975. Opredelitel' rzhavchinnyh gribov SSSR. Nauka i

Tehnika, Minsk (in Russian).

Kürschner, H., 1997. Pflanzen der Türkei: Ägäis - Taurus - Inneranatolien. Quelle \& Meyer Verlag, Wiesbaden (in German).

Kvavadze, E.V., Connor, S.E., 2005. Zelkova carpinifolia (Pallas) K. Koch in Holocene sediments of Georgia - an indicator of climatic optima. Review of Palaeobotany and Palynology 133, 69-89.

Kvavadze, E.V., Efremov, Y.V., 1994. Palynological studies of Holocene lake sediments in the headwaters of the river Bezymianka (West Caucasus). Acta Palaeobotanica 34, 205214.

Kvavadze, E.V., Efremov, Y.V., 1996. Palynological studies of lake and lake-swamp sediments of the Holocene in the high mountains of Arkhyz (western Caucasus). Acta Palaeobotanica 36, 107-119.

Kvavadze, E.V., Rukhadze, L.P., 1989. Rastitel'nost' i klimat Golotsena Abkhazii. Metsniereba, Tbilisi (in Russian).

Kwiecien, O., Arz, H.W., Lamy, F., Wulf, S., Bahr, A., Röhl, U., Haug, G.H., 2008. Estimated reservoir ages of the Black Sea since the Last Glacial. Radiocarbon 50 (1), 99-118.

Kwiecien, O., Arz, H.W., Lamy, F., Plessen, B., Bahr, A., Haug, G.H., 2009. North Atlantic control on precipitation pattern in the eastern Mediterranean / Black Sea region during the last glacial. Quaternary Research 71, 375-384.

Lamy, F., Arz, H.W., Bond, G.C., Bahr, A., Pätzold, J., 2006. Multicentennial-scale hydrological changes in the Black Sea and northern Red Sea during the Holocene and the Arctic/North Atlantic Oscillation. Paleoceanography 21, PA1008, doi:10.1029/2005PA001184.

Litt, T., Krastel, S., Sturm, M., Kipfer, R., Örcen, S., Heumann, G., Franz, S.O., Ülgen, U.B., Niessen, F., 2009. ,PALEOVAN‘, International Continental Scientific Drilling Program (ICDP): site survey results and perspectives. Quaternary Science Reviews 28, 1555 1567.

Louis, H., 1939. Das natürliche Pflanzenkleid Anatoliens. J. Engelhorns Nachf. Adolf Spemann, Stuttgart (in German). 
Marinova, E., Atanassova, J., 2006. Anthropogenic impact on vegetation and environment during the Bronze Age in the area of Lake Durankulak, NE Bulgaria: Pollen, microscopic charcoal, non-pollen palynomorphs and plant macrofossils. Review of Palaeobotany and Palynology 141, 165-178.

Marret, F., Zonneveld, K.A.F., 2003. Atlas of modern organic-walled dinoflagellate cyst distribution. Review of Palaeobotany and palynology 125, 1-200.

Marret, F., Leroy, S., Chalié, F., Gasse, F., 2004. New organic-walled dinoflagellate cysts from recent sediments of Central Asian seas. Review of Palaeobotany and Palynology 129, 1-20.

Marret, F., Mudie, P., Aksu, A., Hiscott, R.N., 2009. A Holocene dinocyst record of a twostep transformation of the Neoeuxinian brackish water lake into the Black Sea. Quaternary International 197, 72-86.

Masson-Delmotte, V., Landais, A., Combourieu-Nebout, N., von Grafenstein, U., Jouzel, J., Caillon, N., Chappellaz, J., Dahl-Jensen, D., Johnsen, S.J., Stenni, B., 2005. Rapid climate variability during warm and cold periods in polar regions and Europe. C.R.Geoscience 337, 935-946.

Mayer, H., Aksoy, H., 1986. Wälder der Türkei. Gustav Fischer Verlag, Stuttgart-New York (in German).

Meehl, G.A., Stocker, T.F., Collins, W.D., Friedlingstein, P., Gaye, A.T., Gregory, J.M., Kitoh, A., Knutti, R., Murphy, J.M., Noda, A., Raper, S.C.B., Watterson, I.G., Weaver, A.J., Zhao, Z.-C., 2007. Global Climate Projections. In: Solomon, S., D. Qin, M. Manning, Z. Chen, M. Marquis, K.B. Averyt, M. Tignor and H.L. Miller (eds.), Climate Change 2007: The Physical Science Basis. Contribution of Working Group I to the Fourth Assessment Report of the Intergovernmental Panel on Climate Change. Cambridge University Press, Cambridge, United Kingdom and New York, NY, USA, SM 10.1-10.8.

Mertens, K.N., Bradley, L.R., Takano, Y., Mudie, P.J., Marret, F., Aksu, A.E., Hiscott, R.N., Verleye, T.J., Mousing, E.A., Smyrnova, L.L., Bagheri, S., Mansor, M., Pospelova, V., Matsuoka, K., 2012. Quantitative estimation of Holocene surface salinity variation in the Black Sea using dinoflagellate cyst process length. Quaternary Science Reviews, doi:10.1016/j.quascirev.2012.01.026.

Mikhailov, V.N., Mikhailova, M.V., 2008. River mouths. In: Kostianoy, G., Kosarev, A.N. (Eds.), The Handbook of Environmental Chemistry: Vol.5, Part Q: The Black Sea Environment. Springer Verlag, Berlin - Heidelberg, pp. 91-133. 
Moore, P.D., Webb, J.A., Collinson, M.E., 1999. Pollen analysis. Blackwell, Oxford.

Moreno, A., Cacho, I., Canals, M., Prins, M.A., Sánchez-Goñi, M.F., Grimalt, J.O., Weltje, G.J., 2002. Saharan Dust Transport and High-Latitude Glacial Climatic Variability: The Alboran Sea Record. Quaternary Research 58, 318-328.

Moreno, A., Cacho, I., Canals, M., Grimalt, J.O., Sanchez-Vidal, A., 2004. Millenial-scale variability in the productivity signal from the Alboran Sea record, Western Mediterranean Sea. Palaeogeography, Palaeoclimatology, Palaeoecology 211, 205-219.

Moreno, A., Cacho, I., Canals, M., Grimalt, J.O., Sánchez-Goñi, M.F., Shackleton, N.J., Sierro, F.J., 2005. Links between marine and atmospheric processes oscillating on a millennial time-scale. A multi-proxy study of the last 50,000 yr from the Alboran Sea (Western Mediterranean Sea). Quaternary Science Reviews 24, 1623-1636.

Mudie, P.J., Aksu, A.E., Yasar, D., 2001. Late Quaternary dinoflagellate cysts from the Black, Marmara and Aegean seas: variations in assemblages, morphology and paleosalinity. Marine Micropaleontology 43, 155-178.

Mudie, P.J., Rochon, A., Aksu, A.E., 2002a. Pollen stratigraphy of Late Quaternary cores from Marmara Sea: land-sea correlation and paleoclimatic history. Marine Geology 190, 233-260.

Mudie, P.J., Rochon, A., Aksu, A.E., Gillespie, H., 2002b. Dinoflagellate cysts, freshwater algae and fungal spores as salinity indicators in Late Quaternary cores from the Marmara and Black Seas. Marine Geology 190, 203-231.

Mudie, P.J., Rochon, A., Aksu, A.E., Gillespie, H., 2004. Late glacial, Holocene and modern dinoflagellate cyst assemblages in the Aegean - Marmara - Black Sea corridor: statistical analysis and re-interpretation of the early Holocene Noah's Flood hypothesis. Review of Palaeobotany and Palynlogy 128, 143-167.

Mudie, P.J., Marret, F., Aksu, A.E., Hiscott, R.N., Gillespie, H., 2007. Palynological evidence for climatic change, anthropogenic activity and outflow of Black Sea water during the late Pleistocene and Holocene: Centennial- to decadal-scale records from the Black and Marmara Seas. Quaternary International 167-168, 73-90.

Mudie, P.J., Leroy, S.A.G., Marret, F., Gerasimenko, N.P., Kholeif, S.E.A., Sapelko, T., Filipova-Marinova, M., 2011. Nonpollen palynomorphs: indicators of salinity and environmental change in the Caspean - Black Sea - Mediterranean corridor. In: Buynevich, I.V., Yanko-Hombach, V., Gilbert, A.S., Martin, R.E. (Eds.) Geology and Geoarcheology of the Black Sea region: Beyond the flood hypothesis. The Geological Society of America, Colorado, pp. 89-115. 
Müllenhoff, M., Handl, M., Knipping, M., Brückner, H., 2004. The evolution of Lake Bafa (Western Turkey) - sedimentological, microfaunal and palynological results. Coastline Reports 1, 55-66.

Müller, U.C., Pross, J., Tzedakis, P.C., Gamble, C., Kotthoff, U., Schmiedl, G., Wulf, S., Christianis, K., 2011. The role of climate in the spread of modern humans into Europe. Quaternary Science Reviews 30, 273-279.

Murray, J.W., Fuchsman, C., Kirkpatrick, J., Paul, B., Konovalov, S.K., 2005. Species and $\delta 15 \mathrm{~N}$ Signatures of nitrogen transformations in the Suboxic Zone of the Black Sea. Oceanography 18, 36-47.

Neustadt, M.I., 1955. K istorii lesov severnogo sklona Bol'shogo Kavkaza v Golotsene. Doklady Akademii nauk SSSR 102, 617-619.

Neustadt M.I. (Ed.), 1965. Paleogeographiya i khronologiya verkhnego pleistocena i golocena po dannym radiouglerodnogo metoda. Nauka, Moskva (in Russian).

Neprochnov, Yu.P. (Ed.), 1980. Geologicheskaya istoriya Chernogo moria po resul'tatam glubokovodnogo bureniya. Nauka, Moskva (in Russian).

Nevesskaya, L.A., 1965. Pozdnechetvertichnye dvustvorchatye molluski Chernogo moria, ih sistematika i ekologiya. Izdatel'stvo Akademii Nauk, Moskva (in Russian).

Nezlin, N.P., 2008. Seasonal and Interannual Variability of Remotely Sensed Chlorophyll. In: Kostianoy, G., Kosarev, A.N. (Eds.) The Handbook of Environmental Chemistry: Vol.5, Part Q: The Black Sea Environment. Springer Verlag, Berlin - Heidelberg, pp. 333-349.

Nowack, E., 1931. Journey in Northern Anatolia. Geographical Review 21, 70-92.

Nowack, E., Markgraf, F., 1928. Die Grenze zwischen der kolchischen Waldvegetation und der Hochlandsvegetation im nördlichen Kleinasien. Die Naturwissenschaften 40, 753757 (in German).

Nowaczyk, N.R., Arz, H.W., Frank, U., Kind, J., Plessen, B., 2012. Dynamics of the Laschamp geomagnetic excursion from Black Sea sediments. Earth and Planetary Science Letters 351-352, 54-69.

Otto-Bliesner, B.L., Marshall, S.J., Overpeck, J.T., Miller, G.H., Hu, A., CAPE Last Interglacial Project members, 2006. Simulating Arctic Climate Warmth and Icefield Retreat in the Last Interglaciation. Science 311, 1751-1753.

Oguz, T., Latun, V.S., Latif, M.A., Vladimirov, V.V., Sur, H.I., Markov, A.A., Özsoy, E., Kotovshchikov, B.B., Eremeev, V.V., Ünlüata, Ü., 1993. Circulation in the surface and intermediate layers of the Black Sea. Deep-Sea Research 40, 1597-1612. 
Özsoy and Ünlüata, 1997. Oceanography of the Black Sea: a review of some recent results. Earth-Science Reviews 42, 231-272.

Quézel, P., Barbéro, M., 1985. Carte de la vegetation potentielle de la région méditerranéenne. Feuille No. 1: Méditerranée orientale. C.N.R.S. Paris (in French).

Prentice, I.C., Cramer, W., Harrison, S.P., Leemans, R., Monserud, R.A., Solomon, A.M., 1992. A global biome model based on plant physiology and dominance, soil properties, and climate. Journal of Biogeography 19, 117-134.

Prentice, I.C., Guiot, J., Huntley, B., Jolly, D., Cheddadi, R., 1996. Reconstructing biomes from palaecological data: a general method and its application to European pollen data at 0 and $6 \mathrm{ka}$. Climate Dynamics 12, 185-194.

Rahmstorf, S., 2002. Ocean circulation and climate during the past 120,000 years. Nature 419, 207-214.

Roberts, N., 1983. Age, Palaeoenvironments, and Climatic Significance of Late Pleistocene Konya Lake, Turkey. Quaternary Research 19, 154-171.

Roberts, N., Wright, H.E., 1993. Vegetational, Lake-Level, and Climatic History of Near East and Southwest Asia, in: Wright, H.E., Kutzbach, J.E., Webb III, T., Ruddiman, W.F., Street-Perrott, F.A., Bartlein, P.J. (Eds.), Global Climates since the Last Glacial Maximum. University of Minnesota Press, Minneapolis, London, pp.194-220.

Rochon, A., Vernal, A. de, Turon, J.-L., Matthiessen, J., Head, M.J., 1999. Distribution of recent dinoflagellate cysts in surface sediments from the north Atlantic ocean and adjacent seas in relation to sea-surface parameters. AASP Contributions Series 35, 7-59.

Rohling, E.J., Grant, K., Hemleben, Ch., Siddal, M., Hoogakker, B.A.A., Bolshaw, M., Kucera, M., 2007. High rates of sea-level rise during the last interglacial period. Nature Geoscience 1, 38-42.

Ross, D.A., Degens, E.T. (Ed.), 1974. The Black Sea - Geology, Chemistry and Biology. Collegiate Press George Banta Company, Menasha, Wisconsin.

Ross, D.A., Neprochnov, Y.P., Hsü, K.J., Stoffers, P., Supko, P., Trimonis, E.S., Percival, S.F., Erickson, A.J., Degens, E.T., Hunt, J.M., Manheim, F.T., Senalp, M., Traverse, A., 1978. Initial Reports of the Deep Sea Drilling Project. Volume XLII. Part 2 covering Leg 42, Part 2, of the cruises on the Drilling Vessel Glomar Challenger Istanbul, Turkey May-June 1975. U.S. Government Printing Office, Washington.

Ryan, W.B.F., Pitman, III, W.C., 1998. Noah's Flood: The New Scientific Discoveries about Events that Changed History. Simion and Schuster, New York. 
Sánchez-Goñi, M.F., Eynaud, F., Turon, J.-L., Shackleton, N.J., 1999. High resolution palynological record off the Iberian margin: direct land-sea correlation for the last Interglacial complex. Earth and Planetary Science Letters 171, 123-137.

Sánchez-Goñi, Turon, J.-L., M.F., Eynaud, F., Gendreau, S., 2000. European Climatic Response to Millenial-Scale Changes in the Atmosphere-Ocean System during the Last Glacial Period. Quaternary Research 54, 394-403.

Sánchez-Goñi, M.F., Cacho, I., Turon, J.-L., Guiot, J., Sierro, F.J., Peypouquet, J.-P., Grimalt, J.O., Shackleton, N.J., 2002. Synchroneity between marine and terrestrial responses to millennial scale climatic variability during the last glacial period in the Mediterranean region. Climate Dynamics 19, 95-105.

Sánchez-Goñi, M.F., Loutre, M.F., Crucifix, M., Peyron, O., Santos, L., Duprat, J., Malaizé, B., Turon, J.-L., Peypouquet, J.-P., 2005. Increasing vegetation and climate gradient in Western Europe over the Last Glacial Inseption (122-110 ka): data-model comparison. Earth and Planetary Science Letters 231, 111-130.

Sarikaya, M.A., Zreda, M., Çiner, A., Zweck, C., 2008. Cold and wet Last Glacial Maximum on Mount SandIras, SW Turkey, inferred from cosmogenic dating and glacier modeling. Quaternary Science Reviews 27, 769-780.

Shackleton, N.J., Sánchez-Goñi, M.F., Pailler, D., Lancelot, Y., 2003. Marine Isotope Substage 5e and the Eemian Interglacial. Global and Planetary Change 36, 151-155.

Shatilova, I.I., 1974. Palinologicheskoe obosnovanie geokhronologii verhnego Pliotsena i Pleistotsena zapadnoy Gruzii. Metsniereba, Tbilisi (in Russian).

Shatilova, I., Mchedlishvili, N., Rukhadze, L., Kvavadze, E., 2011. The history of the flora and vegetation of Georgia (South Caucasus). Georgian National Museum, Tbilisi.

Shopov, V.L., Božilova, E.D., Atanasova, J.R., 1992. Biostratigraphy and radiocarbon data of Upper Quaternary sediments from western part of Black Sea. Geologica Balcanica 22, 59-69.

Spiridonova, E.A., 1991. Evolutsiya rastitel'nogo pokrova bassejna Dona v verhnem Pleistocene-Golocene [Vegetation development in the Don drainage-basin in the Late Pleistocene and Holocene]. Nauka, Moscow (in Russian).

Stefanova, I., Oeggl, K., 1993. Zur holozänen Vegetationsgeschichte SW-Bulgariens: Das Moor Praso im Pirin-Gebirge. Ber. nat.-med. Verein Innsbruck 80, 69-80 (in German).

Stel'makh, L.V., Babich, I.I., Tugrul, S., Moncheva, S., Stefanova, K., 2009. Phytoplankton growth rate and zooplankton grazing in the Western part of the Black Sea in the autumn period. Oceanology 49 (1), 83-92. 
Stockmarr, J., 1971. Tablets with Spores used in Absolute Pollen Analysis. Pollen et Spores $13,615-621$.

Svitoch, A.A., 2003. Morskoy Pleistcene poberezhiy Rossii. GEOS, Moskva (in Russian).

Svitoch, A.A., 2008. Quaternary Paleogeography of the Azov-Black Sea Basin. In: Kostianoy, G., Kosarev, A.N. (Eds.), The Handbook of Environmental Chemistry: Vol.5, Part Q: The Black Sea Environment. Springer Verlag, Berlin - Heidelberg, pp. 31-46.

Tantau, I., Peille, M., de Beaulieu, J.-L., Farcas, S. Goslar, T., Paterne, M., 2003. Vegetation history in the Eastern Romanian Carpathians: pollen analysis of two sequences from Mohoş crater. Vegetation History and Archeobotany 12, 113-125.

Tonkov, S., Beug, H.-J., Božilova, E., Filipova-Marinova, M., Jungner, H., 2011. Palaeoecological studies at the Kaliakra area, northeastern Bulgarian Black Sea coast: 6000 years of natural and anthropogenic change. Vegetation History and Archaeobotany 20, 29-40.

Traverse, A., 1974. Palynological investigation of two Black Sea cores. In: Degens, E.T., Ross, D.A. (eds.) The Black Sea: geology, chemistry and biology. Am. Assoc. Petrol. Geol. Mem. 20, Tulsa, Oklahoma, 381-388.

Tumadzhanov, I.N., Margalitadze, N.A., 1961. K istorii lesov Kartalinskogo I Kahetinskogo hrebtov v Golotsene. Soobshcheniia Akademii Nauk Gruzinskoi SSR 27, 451-458.

Tuzhilkin, V.S., 2008. Thermohaline Structure of the Sea. In: Kostianoy, G., Kosarev, A.N. (Eds.), The Handbook of Environmental Chemistry: Vol.5, Part Q: The Black Sea Environment. Springer Verlag, Berlin - Heidelberg, 217-253.

Tzedakis, P.C., 1999. The last climatic cycle at Kopais, central Greece. Journal of the Geological Society 156, 425-434.

Tzedakis, P.C., 2007. Seven ambiguities in the Mediterranean palaeoenvironmental narrative. Quaternary Science Reviews 26, 2042-2066.

Uçkaç, Ş., 2005. Sea surface variability in the Aegean Sea. E.U. Journal of Fisheries \& Aquatic Sciences 22, 129-135.

Van Geel, B., Coope, G., Hammen, T. van der, 1989. Palaeoecology and stratigraphy of the Late Glacial type section at Usselo (the Netherlands). Review of Palaeobotany and Palynology 60, 25-129.

Van Geel, B., Buurman, J., Brinkkemper, O., Schelvis, J, Aptroot, A., Reenen, G. van, Hakbijl, T., 2003. Environmental reconstructions of a Roman Period settlement site in Uitgeest (the Netherlands), with special reference to coprophilous fungi. Journal of Archaeological Science 30, 873-884. 
Van Zeist, W., Woldring, H., 1978. A postglacial pollen diagram from lake Van in East Anatolia. Review of Palaeobotany and Palynology 26, 249-276.

Van Zeist, W., Timmers, R.W., Bottema, S., 1970. Studies of modern and Holocene pollen precipitation in southeastern Turkey. Palaeohistoria 14, 19-39.

Van Zeist, W., Woldring, H., Stapert, D., 1975. Late Quaternary vegetation and climate of southwestern Turkey. Palaeohistoria 17, 55-143.

Vánky, K., 1994. European Smut Fungi. Gustav Fischer Verlag, Stuttgart, Jena, New York.

Verleye, T.J., Mertens, K.N., Louwye, S., Arz, H.W., 2009. Holocene salinity changes in the southwestern Black Sea: a reconstruction based on dinoflagellate cysts. Palynology 33, 77-100.

Vermoere, M., Bottema, S., Vanhecke, L., Waelkens, M., Paulissen, E. Smets, E., 2002. Palynological evidence for late-Holocene human occupation recorded in two wetlands in SW Turkey. The Holocene 12, 569-584.

Wall, D., Dale, B., 1974. Dinoflagellates in Late Quaternary deep-water sediments from the Black Sea. In: Degens, E.T. and Ross, D.A. (Eds.), The Black Sea: Its geology, chemistry and biology. American Association of Petroleum Geologists, pp. 364-380.

Wall, D., Dale, B., Harada, K., 1973. Descriptions of new fossil dinoflagellates from the Late Quaternary of the Black Sea. Micropaleontology 19, 18-31.

Wick, L., Lemcke, G., Sturm, M., 2003. Evidence of Lateglacial and Holocene climatic change and human impact in eastern Anatolia: high-resolution pollen, charcoal, isotopic and geochemical records from the laminated sediments of Lake Van, Turkey. The Holocene 13, 665-675.

Wijmstra, T.A., 1969. Palynology of the first 30 meters of a $120 \mathrm{~m}$ deep section in Northern Greece. Acta Botanica Neerlandica 18, 511-527.

Wunsch, 2006. Abrupt climate changes: An alternative view. Quaternary Research 65, 191203.

Yanko-Hombach, V.V., Gilbert, A.S., Panin, N., Dolukhanov, P.M. (Eds.), 2007. The Black Sea Flood Question: Changes in Coastline, Climate and Human Settlement. Springer, Dordrecht.

Yayla, M., Yilmaz, A., Morkoc, E., 2001. The dynamics of nutrient enrichment and primary production related to recent changes in the ecosystem of the Black Sea. Aquatic Ecosystem Health and Management 4 (1), 33-49.

Yazvenko, S., 1994. Holocene pollen record from a peatland in the West Caucasus, Abkhasia, Black Sea region. Journal of Paleolimnology 12, 65-74. 
Yunev, O.A., Vedernikov, V.I., Basturk, O., Yilmaz, A., Kideys, A.E., Moncheva, S., Konovalov, S.K., 2002. Long-term variations of surface chlorophyll a and primary production in the open Black Sea. Marine Ecology Progress Series 230, 11-28.

Yunev, O.A., Moncheva, S., Carstensen, J., 2005. Long-term variability of vertical chlorophyll a and nitrate profiles in the open Black Sea: eutrophication and climate change. Marine Ecology Progress Series 294, 95-107.

Zatsepin, A.G, Golenko, N.N., Korzh, A.O., Kremenetskii, V.V., Paka, V.T., Poyarkov, S.G., Stunzhas, P.A., 2007. Influence of the dynamics of currents on the hydrophysical structure of the waters and the vertical exchange in the active layer of the Black Sea. Oceanology 47 (3), 301-312.

Zohary, M., 1973. Geobotanical foundations of the Middle East. Fischer, Stuttgart, Amsterdam. 


\section{MANUSCRIPT 1}

\section{Vegetation and environmental dynamics in the southern Black Sea region since 18 kyr BP derived from the marine core 22-GC3}

Lyudmila S. Shumilovskikh ${ }^{\mathrm{a},{ }^{*}}$, Pavel Tarasov ${ }^{\mathrm{b}}$, Helge W. Arz ${ }^{\mathrm{c}}$, Dominik Fleitmann ${ }^{\mathrm{d}, \mathrm{e}}$, Fabienne Marret ${ }^{\mathrm{f}}$, Norbert Nowaczyk ${ }^{\mathrm{g}}$, Birgit Plessen ${ }^{\mathrm{g}}$, Frank Schlütz ${ }^{\mathrm{h}}$, Hermann Behling ${ }^{\mathrm{a}}$

a Department of Palynology and Climate Dynamics, University of Göttingen, Untere Karspüle 2, 37073 Göttingen, Germany

b Institute of Geological Sciences, Palaeontology Department, Free University Berlin, Malteserstr. 74-100, House D, Berlin, 12249, Germany

c Leibniz Institute for Baltic Sea Research Warnemuende, Seestrasse 15, 18119 Rostock-

Warnemuende, Germany

d Oeschger Centre for Climate Change Research, University of Bern, Zähringerstrasse 25, 3012 Bern, Switzerland e Institute of Geological Sciences, Baltzerstrasse 3, 3012 Bern, Switzerland f School of Environmental Sciences, University of Liverpool, Liverpool, L69 7ZT, UK g GeoForschungsZentrum-Potsdam, Telegrafenberg, 14473 Potsdam, Germany h Lower Saxony Institute for Historical Coastal Research, Viktoriastrasse 26/28, 26382 Wilhelmshaven, Germany

Published in:

Palaeogeography, Palaeoclimatology, Palaeoecology, 337-338, 177-193 (2012)

(C) 2012 Elsevier B.V. All rights reserved.

doi:10.1016/j.palaeo.2012.04.015 


\begin{abstract}
Sediments from the Black Sea, a region historically dominated by forests and steppe landscapes, are a valuable source of detailed information on the changes in regional terrestrial and aquatic environments at decadal to millennial scales. Here we present multi-proxy environmental records (pollen, dinoflagellate cysts, $\mathrm{Ca}, \mathrm{Ti}$ and oxygen isotope data) from the uppermost $305 \mathrm{~cm}$ of the core $22-\mathrm{GC} 3\left(42^{\circ} 13.53^{\prime} \mathrm{N}, 36^{\circ} 29.55^{\prime} \mathrm{E}\right)$ collected from a water depth of $838 \mathrm{~m}$ in the southern part of the Black Sea in 2007. The records span the last $\sim 18$ kyr (all ages are given in cal kyr BP). The pollen data reveal the dominance of the Artemisiasteppe in the region, suggesting rather dry / cold environments $\sim 18-14.5 \mathrm{kyr}$ BP. Warming / humidity increase during melt-water pulses $(\sim 16.1-14.5 \mathrm{kyr} \mathrm{BP})$, indicated by $\delta^{18} \mathrm{O}$ records from the 22-GC3 core sediment and from the Sofular Cave stalagmite, is expressed in more negative $\delta^{13} \mathrm{C}$ values from the Sofular Cave, usually interpreted as the spreading of C3 plants. The records representing the interstadial complex ( 14.5-12.9 kyr BP) show an increase in temperature and moisture, indicated by forest development, increased primary productivity and reduced surface run-off, whereas the switch from primary terrigenous to primary authigenic Ca origin occurs $\sim 500$ yr later. The Younger Dryas cooling is clearly demonstrated by more negative $\delta^{13} \mathrm{C}$ values from the Sofular Cave and a reduction of pines. The early Holocene (11.7-8.5 kyr BP) interval reveals relatively dry conditions compared to the mostly moist and warm middle Holocene (8.5-5 kyr BP), which is characterized by the establishment of the species-rich warm mixed and temperate deciduous forests in the low elevation belt, temperate deciduous beech-hornbeam forests in the middle and cool conifer forest in upper mountain belt. The border between the early and middle Holocene in the vegetation records coincides with the opening of the Mediterranean corridor at $\sim 8.3 \mathrm{kyr}$ BP, as indicated by a marked change in the dinocyst assemblages and in the sediment lithology. Changes in the pollen assemblages indicate a reduction in forest cover after $\sim 5 \mathrm{kyr} \mathrm{BP}$, which was likely caused by increased anthropogenic pressure on the regional vegetation.
\end{abstract}

Keywords: pollen, biomes, multi-proxy reconstruction, late-glacial, Holocene, Northern Anatolia 


\section{Introduction}

The Black Sea region is influenced by subtropical Mediterranean, temperate European, and continental Asian air masses (e.g. Özsoy and Ünlüata, 1997), which make sedimentary archives from the Black Sea a valuable source of information about past environmental and climate dynamics and for validation of climate model simulations. Moreover, the Balkans, Pontic Mountains and Colchis with their warm and moist climate are optimal for forest vegetation, and are of particular importance for the discussion of glacial refugia for thermophilous taxa. In particular, the Balkans and the low-mountain areas along the south and east coasts of the Black Sea were suggested as refugia for temperate deciduous trees by modelling (Leroy and Arpe, 2007), phylogeographical (Médail and Diadema, 2009), and pollen studies (Bottema et al., 1995; Tarasov et al., 2000; Brewer et al., 2002; Arslanov et al., 2007; Connor and Kvavadze, 2008).

The sensitivity of the Black Sea region to climatic changes during the late-glacial and the Holocene was revealed by recent studies, which demonstrated the prompt response of these ecosystems to Heinrich events 1 and 2 (Bahr et al., 2008; Kwiecien et al., 2009), to melt-water pulses during termination 1, warmer / wetter conditions during the late-glacial interstadial, and cooling during the late-glacial stadial (e.g. Bahr et al., 2005, 2006, 2008; Filipova-Marinova, 2006b). Connection to the Caspian Sea during the late-glacial and opening of the corridor between the Mediterranean Sea and the Black Sea around 8.3 kyr BP have also been discussed (e.g. Bahr et al., 2005, 2006; Lamy et al., 2006; Marret et al., 2009; Verleye et al., 2009; Badertscher et al., 2011).

Although the earlier studies on deep-sea core sediments from the Black Sea demonstrated that the main climatic changes can be traced in the pollen records since the Pliocene (Traverse, 1974, 1978; Koreneva and Kartashova, 1978), recent palynological studies in the western (e.g. Filipova et al., 1983; Atanassova and Bozilova, 1992; Shopov et al., 1992; Atanassova, 2005; Filipova-Marinova, 2006a, 2006b; Mudie et al., 2007), central (Mudie et al., 2002a, 2007) and eastern (Kvavadze and Rukhadze, 1989) parts of the basin mainly focus on the Holocene interglacial and partly cover the late-glacial interval. A lack of continuous high-resolution pollen records covering both the late-glacial and the Holocene prevents the robust reconstruction of vegetation and climate history of the region. 


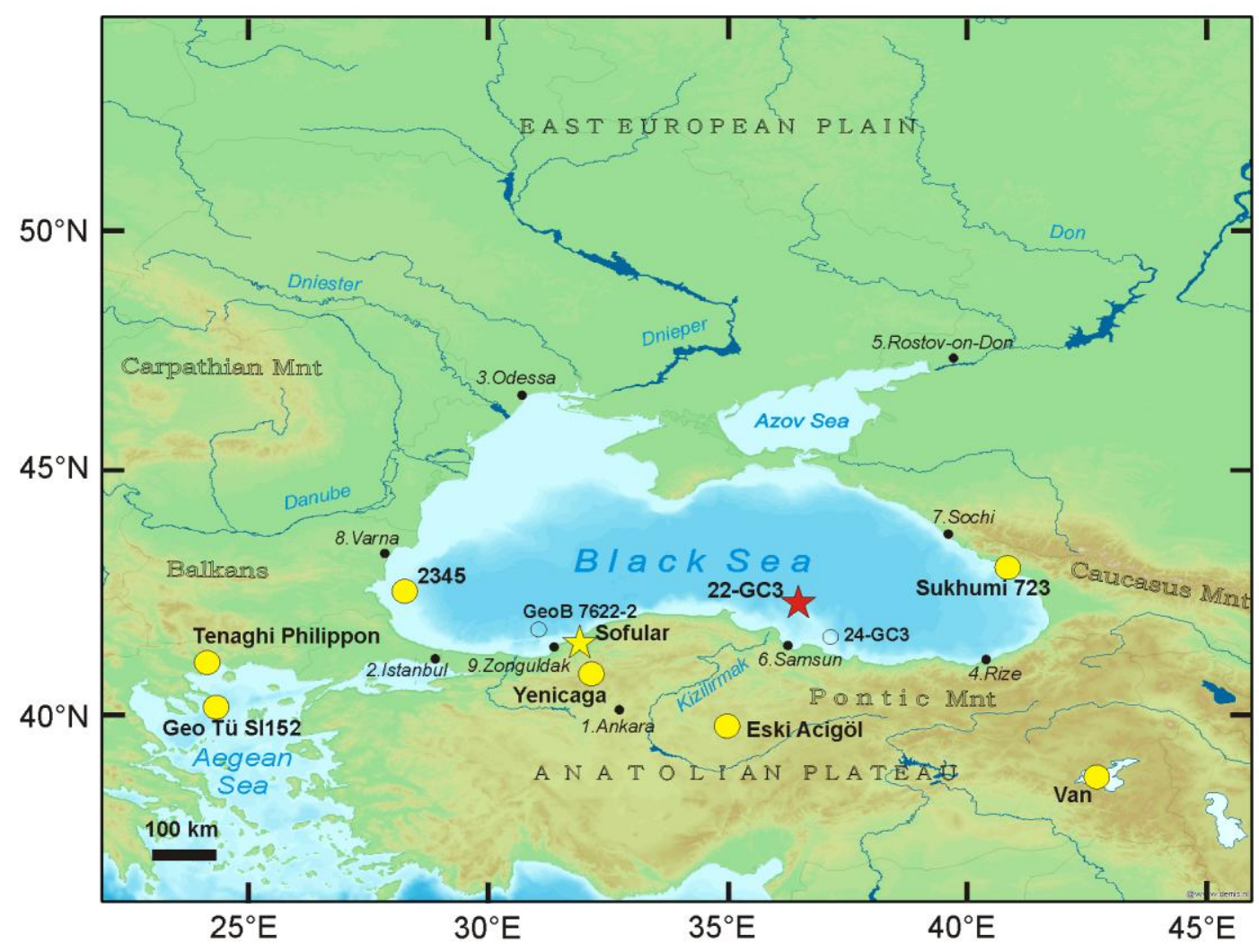

Fig. 1. Physiographic map of the Black Sea region showing locations of the investigated core 22-GC3 (red star), Sofular Cave (yellow star), continuous pollen records referred to and discussed in the text (yellow circles), and cores used for construction of an age-depth model and discussed in the text (uncoloured circles). Black dots with numbers indicate locations of the climate stations presented in Table 1. Map was drawn with Quantum GIS (1.7.0) by using data from www.bgr.de, www.nowcoast.noaa.gov, www2.demis.nl.

In general, the spatial distribution and temporal resolution of paleoclimate records in the region are relatively low and multi-proxy records providing detailed information on oceanatmosphere-land interaction are sparse. Furthermore, the individual proxies often suffer from inadequate age control and allow contradictory interpretations. Geomorphological evidence from Lake Konya (Roberts, 1983) and Eski Acıgöl (Jones et al., 2007) in central Anatolia and the Lisan record from Israel (Bartov et al., 2003) show higher-than-present lake levels prior to $\sim 16.5 \mathrm{ka} \mathrm{BP}$ and a decreasing trend after that time. Advances of mountain glaciers in the central and eastern Mediterranean also suggest that the last glacial maximum (LGM) was wetter than today (Kuhlemann et al., 2008; Sarikaya et al., 2008). On the other hand, pollen records from the eastern Mediterranean point to relatively dry climatic conditions during the Pleniglacial and more humid conditions starting at the onset of the late-glacial interstadial (e.g. Bottema et al., 1995; Kotthoff et al., 2008; Litt et al., 2009; Müller et al., 2011).

Opposing moisture trends in the eastern Mediterranean region are also typical of the Holocene. Oxygen-isotope-based reconstructions from Lake Van reveal an increase in 
moisture already in the early Holocene, whereas parallel pollen-based reconstructions demonstrate a delay of the forest development at this time (Wick et al., 2003). These delays are known from different parts of the eastern Mediterranean region and their reasons are still under discussion (e.g. Roberts et al., 2001; Eastwood et al., 2007; Djamali et al., 2010; Roberts et al., 2011). Since the eastern Mediterranean region is supposed to have been a corridor for human migration from Africa to Europe, climatic and anthropogenic roles in the creation of today's Mediterranean landscapes are of great interest (e.g. Müller et al., 2011; Roberts et al., 2011).

In order to obtain high quality records which would allow robust reconstructions of the late Quaternary environments and contribute to a better understanding of regional environmental and climate dynamics in the Black Sea and northern Anatolian region during the last glacial-interglacial cycle, the interdisciplinary project DynNAP was initiated in 2009. The current study presents the first results from this project, on the uppermost $305 \mathrm{~cm}$ of the core 22-GC3 from the southern Black Sea, spanning the last 18 kyr. Multi-proxy records are used to reconstruct the vegetation and environmental history of the Northern Anatolia since the Pleniglacial. Qualitative environmental and quantitative biome reconstructions based on palynological data from core 22-GC3 are further compared and discussed together with published reconstructions of late-glacial and Holocene environments from the eastern Mediterranean and North Atlantic regions.

\section{Core setting and regional environments}

\subsection{Geographical setting}

The $839 \mathrm{~cm}$ long core $22-\mathrm{GC} 3\left(42^{\circ} 13.53^{\prime} \mathrm{N}, 36^{\circ} 29.55^{\prime} \mathrm{E}\right)$ was collected during cruise M72/5 of the research vessel Meteor from a water depth of $838 \mathrm{~m}$ in the southern part of the Black Sea in 2007 (Fig. 1). The coring site is located only 70-75 km north-east of the Turkish coast, while the distances from the eastern (Georgian), northern (Ukrainian) and western (Bulgarian) coasts of the sea are around 400, 300-500 and $650 \mathrm{~km}$ respectively.

The Black Sea is the largest anoxic basin on earth and occupies a quasi-elliptical tectonic depression at the border between SE Europe and NW Asia. The sea extends for over $1,130 \mathrm{~km}$ along the $42^{\circ} \mathrm{N}$ latitude and for about $610 \mathrm{~km}$ along the $31^{\circ} \mathrm{E}$ longitude. It has an area of $\sim 4.23 \times 10^{5} \mathrm{~km}^{2}$ and a maximal water depth of $\sim 2258 \mathrm{~m}$ (Kosarev and Kostianoy, 2008). The upper 100-150 $\mathrm{m}$ of the sea water, which receives input from more than 500 rivers (the largest, in terms of length and water discharge, flow in from the north) and direct 
atmospheric precipitation, is cooler and less salty $(\sim 18 \%)$ than the deeper waters $(\sim 22 \%$ o $)$ originating from the Mediterranean Sea (e.g. Özsoy and Ünlüata, 1997; Kostianoy and Kosarev, 2008). The well-aerated surface water layer is characterized by a high biological productivity, while deep anoxic water below 100-150 m depth provides unique conditions for anaerobic microbial life and allows good preservation of organic material in the bottom sediments. The general circulation system of the upper layer of the Black Sea is rather complex (Fig. 2) and consists of eastern and western gyres and numerous eddies (see Oguz et al. (1993), Özsoy and Ünlüata (1997), Kostianoy and Kosarev (2008) for details on the Black Sea environment and hydrology).

The areas along the northern and north-western coasts of the Black Sea are predominantly plains and lowlands, except for the Crimean Mountains (maximum elevation $1,545 \mathrm{~m}$ a.s.l). The mountain relief is more pronounced in the coastal regions south and east of the sea. The arc of mountain ranges interrupted by river valleys and deltas includes the Caucasus $(5,633 \mathrm{~m})$ in the east, the Pontic Mountains $(3,937 \mathrm{~m})$ with the Anatolian Plateau in the south, and the Rhodopes (2,925 m), Balkans (2,376 m) and Carpathian Mountains (2,543 $\mathrm{m})$ in the west.

The regional climate - temperate in the north and subtropical in the south - is controlled by seasonal changes in the position and strength of the Azores High and Icelandic Low and in the westerly storm tracks (Türkeş, 1996), while a significant amount of moisture originates from the Black Sea (Badertscher et al., 2011). In the summertime, the belt of moist westerly winds shifts northward and the Mediterranean high-pressure zone provides warm and dry air for the entire region from the Balkan Peninsula to central Anatolia in the east and as far as the Crimean Peninsula in the north. The summers are warm in the Black Sea region with mean July temperatures above $20^{\circ} \mathrm{C}$, except for the high-altitude mountain areas (Table 1). In winter, generally cold weather is caused by cold air masses from continental Asia controlled by the Siberian High. The mean January temperatures are around zero at low elevations, while the mountains and lowlands in the north experience temperatures below freezing (Table 1). 
Table 1. Modern climate data from the meteorological stations (see Fig. 1 for the locations) situated around the Black Sea (after www.klimadiagramme.de). 'Warm' part of the year represents interval from April to September and 'cold' part of the year represents interval from October to March.

\begin{tabular}{lccccccccc}
\hline \multirow{3}{*}{ Station } & \multicolumn{3}{c}{ Coordinates } & \multicolumn{3}{c}{ Mean Temperatures, ${ }^{\circ} \mathrm{C}$} & \multicolumn{3}{c}{ Precipitation, mm } \\
\cline { 2 - 10 } & $\begin{array}{c}\text { Latitude } \\
{ }^{\circ} \mathrm{N}\end{array}$ & $\begin{array}{c}\text { Longitude } \\
{ }^{\circ} \mathrm{E}\end{array}$ & $\begin{array}{c}\text { Altitude } \\
\mathrm{m} \text { a.s.1. }\end{array}$ & July & January & Year & $\begin{array}{c}\text { Warm } \\
(\mathrm{IV}-\mathrm{IX})\end{array}$ & $\begin{array}{c}\text { Cold } \\
(\mathrm{X}-\mathrm{III})\end{array}$ & Year \\
\hline 1. Ankara & $39^{\circ} 57^{\prime}$ & $32^{\circ} 53^{\prime}$ & 894 & 22.9 & 0 & 11.7 & 186 & 230 & 416 \\
2. Istanbul & $40^{\circ} 58^{\prime}$ & $29^{\circ} 05^{\prime}$ & 40 & 23.2 & 5.4 & 14.1 & 188 & 510 & 698 \\
3. Odessa & $46^{\circ} 29^{\prime}$ & $30^{\circ} 38^{\prime}$ & 64 & 21.5 & -1.5 & 10.2 & 235 & 234 & 469 \\
4. Rize & $41^{\circ} 02^{\prime}$ & $40^{\circ} 30^{\prime}$ & 140 & 22.2 & 6.3 & 13.9 & 870 & 1301 & 2171 \\
5. Rostov-on-Don & $47^{\circ} 15^{\prime}$ & $39^{\circ} 49^{\prime}$ & 77 & 23.1 & -4.6 & 9.6 & 289 & 290 & 579 \\
6. Samsun & $41^{\circ} 17^{\prime}$ & $36^{\circ} 20^{\prime}$ & 4 & 22.7 & 6.9 & 14.3 & 269 & 423 & 692 \\
7. Sochi & $43^{\circ} 35^{\prime}$ & $39^{\circ} 46^{\prime}$ & 34 & 22.7 & 5.9 & 14.0 & 642 & 931 & 1573 \\
8. Varna & $43^{\circ} 12^{\prime}$ & $27^{\circ} 55^{\prime}$ & 43 & 22.0 & 1.9 & 12.1 & 230 & 241 & 471 \\
9. Zonguldak & $41^{\circ} 27^{\prime}$ & $31^{\circ} 48^{\prime}$ & 136 & 21.5 & 6.0 & 13.6 & 435 & 759 & 1194 \\
\hline
\end{tabular}

In the northern part of the Black Sea region, total amounts of precipitation do not exceed $600 \mathrm{~mm} / \mathrm{yr}$ in the low-elevation zone, whereas the north-west-oriented slopes of the Pontic Mountains and Caucasus may receive up to 1000-2500 mm/yr (Table 1) and therefore are among the warmest and wettest in western Eurasia (Alpat'ev et al., 1976; Mayer and Aksoy, 1986). The low-pressure cells from the Atlantic Ocean shift to the south of their summer position and bring moisture to the southern part of the region. The relatively warm waters of the Mediterranean Sea serve as a secondary moisture source, which allows storm tracks to renew their strength as they move eastward (Dobrovolskiy and Zalogin, 1982; Roberts and Wright, 1993; Kosarev et al., 2008). Instrumental data from Turkey and the Black Sea area also suggest that the short-term variations in atmospheric precipitation (Türkeş and Erlat, 2003; Türkeş et al., 2009) and in sea-surface temperatures (Kazmin and Zatsepin, 2007) are influenced by the operation of the North Atlantic Oscillation (NAO), which in turn reflects the large-scale interaction between the north Atlantic and mid-latitude air masses (Hurrell, 1995; Lamy et al., 2006).

\subsection{Vegetation distribution}

Climatic controls, amplified by local topography, play a dominant role in determining the pattern of natural vegetation and pollen distribution in the Black Sea area. The relatively detailed maps showing vegetation patterns in Europe and Asia around the Black Sea are provided in the World Atlas (Gerasimov, 1964) and in a number of regional publications (e.g. Louis, 1939; Zohary, 1973; Alpat'ev et al., 1976; Quézel and Barbéro, 1985; Mayer and 
Aksoy, 1986; Frey and Kürschner, 1989; Kürschner, 1997). The main vegetation types shown on the large-scale maps (Gerasimov, 1964) include different types of conifer and temperate deciduous forests, as well as sub-Mediterranean and Mediterranean forests, woodlands and shrublands, Artemisia-dominated steppes on the Anatolian plateau and north of the Black Sea, and alpine meadows in the high mountains (Fig. 2). Table 2 provides simplified characteristics of vegetation types used in botanical literature (e.g. Gerasimov, 1964) and their correspondence to global biome classification used by Prentice et al. (1992; 1996).

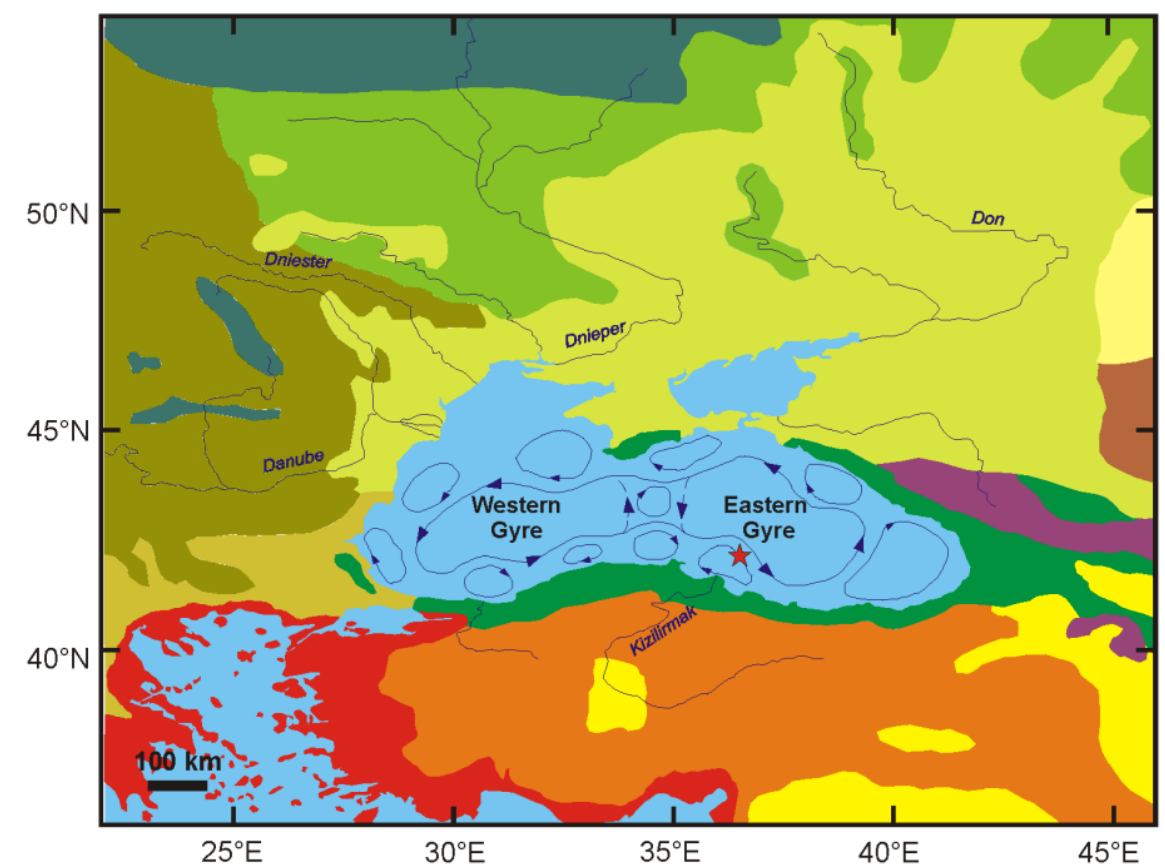

Legend:

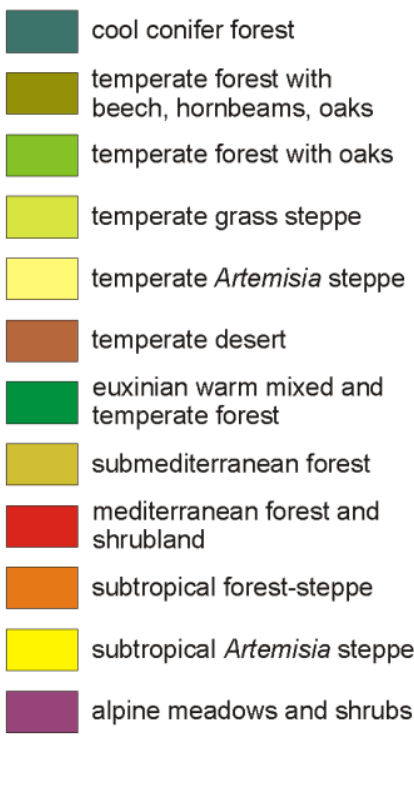

Fig. 2. Map of the Black Sea region showing key vegetation types (modified from Gerasimov, 1964; Zohary, 1973) and the upper-layer general circulation system in the Black Sea (modified from Oguz et al., 1993). Thick blue lines indicate the main water current with eastern and western gyres; and eddies are indicated by thin blue lines.

In addition to the regional vegetation distribution map (Fig. 2) Figure 3 presents a simplified vegetation profile across the Pontic Mountains (Mayer and Aksoy, 1986; Kürschner, 1997). As the mountain range nearest to the core 22-GC3 site (Fig. 1), it should be considered as a major pollen source area for the core sediments, with consideration of wind patterns, river input and gyre systems in the Black Sea. The wetter northern and western slopes of the Pontic Mountains up to $\sim 800 \mathrm{~m}$ a.s.l. are covered by the euxinian forest type, which consists of mainly temperate summer-green tree taxa (Castanea sativa, Corylus, Tilia, Carpinus betulus, Fagus orientalis, different species of Quercus), evergreen broadleaved trees and shrubs (Rhododendron ponticum, Prunus laurocerasus, Buxus sempervierens, Ilex colchica) and lianas (Hedera helix, Smilax, Vitis, Periploca). 
Table 2. Regional vegetation formations/assemblages (simplified from Gerasimov, 1964) and their allocation to biomes used by Prentice et al. (1996). Abbreviated biome names are used as follows: TUND for tundra, COCO for cool conifer forest, TEDE for temperate deciduous forest, WAMX for warm mixed forest, XERO for xerophytic woods/scrub, STEP for steppe and DESE for desert.

\begin{tabular}{|c|c|c|}
\hline Formations & Vegetation assemblages & Biome \\
\hline \multicolumn{3}{|l|}{ Boreal forest } \\
\hline & Pinus-forest with oaks & $\mathrm{COCO}$ \\
\hline & Mixed broad-leaved forest (Picea excelsa, Quercus robur, Quercus petraea) & $\mathrm{COCO}$ \\
\hline & Carpathian dark-conifer forest (Picea excelsa, Abies alba) & $\mathrm{COCO}$ \\
\hline \multicolumn{3}{|l|}{$\begin{array}{l}\text { Temperate forest } \\
\text { formations }\end{array}$} \\
\hline \multirow[t]{5}{*}{ central european } & $\begin{array}{l}\text { Mixed broad-leaved forest (Quercus robur, Quercus petraea, Quercus cerris, Quercus } \\
\text { frainetto, Carpinus betulus, Tilia cordata) }\end{array}$ & TEDE \\
\hline & Danube oak steppe-forest (Quercus robur, Quercus petraea, Quercus pubescens) & TEDE \\
\hline & $\begin{array}{l}\text { Quercus-Fagus-Carpinus-forest (Fagus sylvatica, Quercus robur, Quercus petraea, } \\
\text { Carpinus betulus) }\end{array}$ & TEDE \\
\hline & Fagus sylvatica-forest & TEDE \\
\hline & $\begin{array}{l}\text { Mountain mixed conifer-broad-leaved-forest (Fagus sylvatica, Abies alba, Picea excelsa, } \\
\text { Pinus sylvestris) }\end{array}$ & $\mathrm{COCO}$ \\
\hline \multirow[t]{6}{*}{ eastern european } & Oak forest (Quercus robur, Tilia cordata, Acer spp.) & TEDE \\
\hline & Pine-broad-leaved forest (Pinus sylvestris, Quercus robur) & $\mathrm{COCO}$ \\
\hline & $\begin{array}{l}\text { North-Caucasian mountain oak- and oak-hornbeam-forest (Quercus robur, Quercus } \\
\text { petraea, Carpinus caucasica) }\end{array}$ & TEDE \\
\hline & Mountain beech- and oak-beech-forest (Fagus orientalis) & TEDE \\
\hline & $\begin{array}{l}\text { Mountain beech-conifer forest (Abies nordmanniana ssp. nordmanniana, Abies } \\
\text { nordmanniana ssp. bornmuelleriana, Picea orientalis, Fagus orientalis) }\end{array}$ & $\mathrm{COCO}$ \\
\hline & Broad-leaved forest with evergreen elements & WAMX \\
\hline submediterranean & Oak forests and pseudo-macchia (Quercus pubescens, Quercus frainetto etc.) & TEDE \\
\hline \multicolumn{3}{|l|}{ Temperate steppe } \\
\hline & Meadow-steppe (Stipa, Festuca, Bromus and herbs) with oaks & TEDE \\
\hline & $\begin{array}{l}\text { Herb-grass steppe (Filipendula hexapetala, Salvia nutans, Stipa ukrainica, Stipa } \\
\text { stenophylla, Stipa rubentiformis) }\end{array}$ & STEP \\
\hline & Stipa steppe (Stipa ukrainica, Stipa lessingiana) & STEP \\
\hline & $\begin{array}{l}\text { Artemisia-grass steppe (Artemisia maritima, Artemisia taurica, Stipa capillata, Festuca } \\
\text { sulcata, Agropyron pectiniforme) }\end{array}$ & STEP \\
\hline & $\begin{array}{l}\text { North-Caucasian mountain grass (Stipa capillata, Bromus riparius, Festuca sulcata), } \\
\text { herb-grass steppe and steppe-meadows }\end{array}$ & STEP \\
\hline & Artemisia-steppe and northern semidesert (Artemisia lercheana, Festuca, Stipa) & STEP \\
\hline & $\begin{array}{l}\text { Grass-Artemisia steppe and southern semidesert (Artemisia lercheana, Artemisia } \\
\text { pauciflora) }\end{array}$ & STEP \\
\hline \multicolumn{3}{|c|}{ 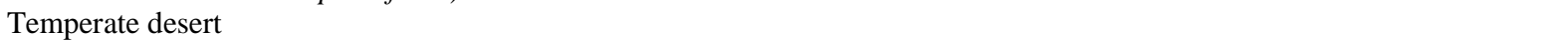 } \\
\hline & $\begin{array}{l}\text { Artemisia-chenopod desert (Artemisia lercheana, Artemisia paucifora, Artemisia } \\
\text { astrachanica, Artemisia arenaria, Atriplex, Anabasis, Suaeda) }\end{array}$ & DESE \\
\hline & Chenopod desert (Anabasis salsa) with Artemisia (Artemisia lercheana) & DESE \\
\hline \multicolumn{3}{|l|}{ Subtropical forest } \\
\hline $\begin{array}{l}\text { Mediterranean forest } \\
\text { and shrubland }\end{array}$ & $\begin{array}{l}\text { Evergreen and deciduous oak forest (Quercus coccifera, Quercus ilex, Quercus } \\
\text { ithaburensis ssp. macrolepis, Quercus calliprinos, Quercus libani, Quercus infectoria) } \\
\text { with pines (Pinus brutia, Pinus halepensis) and macchia }\end{array}$ & XERO \\
\hline \multirow[t]{3}{*}{ Dry forest } & Submediterranean sparse pine forest (Pinus nigra, Pinus brutia) with oaks and junipers & TEDE \\
\hline & $\begin{array}{l}\text { Mountain dark-conifer forest (Abies cilicica, Cedrus libani) with deciduous and } \\
\text { evergreen broad-leaved elements }\end{array}$ & $\mathrm{COCO}$ \\
\hline & $\begin{array}{l}\text { Mountain dry sparse oak-juniper-pine forests on Armenian highland (Quercus infectoria, } \\
\text { Quercus brantii, Juniperus excelsa, Pinus hamata) }\end{array}$ & TEDE \\
\hline \multicolumn{3}{|c|}{ 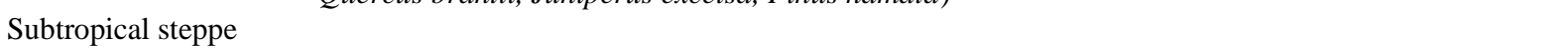 } \\
\hline & $\begin{array}{l}\text { Mountain herbs-grass steppe (Stipa, Festuca sulcata, Koeleria, Bromus, Poa bulbosa, } \\
\text { Coplodinium humilis, Astragalus) with Artemisia (Artemisia fragrans, Artemisia } \\
\text { austriaca) }\end{array}$ & STEP \\
\hline & $\begin{array}{l}\text { Herbs-grass submediterranean mountain steppe with shrubs (Stipa, Bromus, Salvia, } \\
\text { Anchusa, Centaurea, Trigonella, Cousinia, Artemisia herba-alba) }\end{array}$ & STEP \\
\hline \multicolumn{3}{|c|}{ 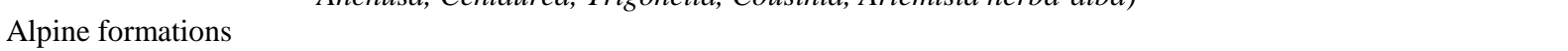 } \\
\hline & Meadows & TUND \\
\hline & Juniper meadows & TUND \\
\hline & Caucasian meadows with rhododendron and tundra & TUND \\
\hline
\end{tabular}


This combination of taxa has been assigned to the temperate deciduous forest biome (TEDE) by Prentice et al. (1996). However, Laurus, Arbutus andrachne, Erica arborea and evergreen Quercus - warm mixed forest biome (WAMX) indicators - are characteristic of Mediterranean macchia growing in southern and south-western Anatolia and can also be found in the coastal area of the Black Sea (Louis, 1939; Zohary, 1973; Mayer and Aksoy, 1986). At higher elevations ( 800-1500 m a.s.1.), beech (F. orientalis) or hornbeam-beech (Carpinus-Fagus) forests corresponding to the temperate deciduous forest biome (TEDE) predominate. Higher altitudes (above $\sim 1500 \mathrm{~m}$ ) in the western part of the mountains are occupied by fir (Abies nordmanniana ssp. bornmuelleriana) and in the eastern part by fir (A. nordmanniana ssp. nordmanniana) and spruce (Picea orientalis) cool conifer (COCO) taigalike (TAIG) forests. Grasslands dominate in the subalpine and alpine mountain belt above 2000 m a.s.l. The south-east mountain slopes facing the Anatolian Plateau are covered with drier vegetation types, including open woodland dominated by eurythermic conifers (e.g. Pinus nigra, Juniperus excelsa, J. oxycedrus) and deciduous oaks (Quercus pubescens, $Q$. trojana). Above $\sim 2000 \mathrm{~m}$ elevation subalpine thorny shrubs (Astracanthus spec., Sarcopoterium spec.) are characteristic.

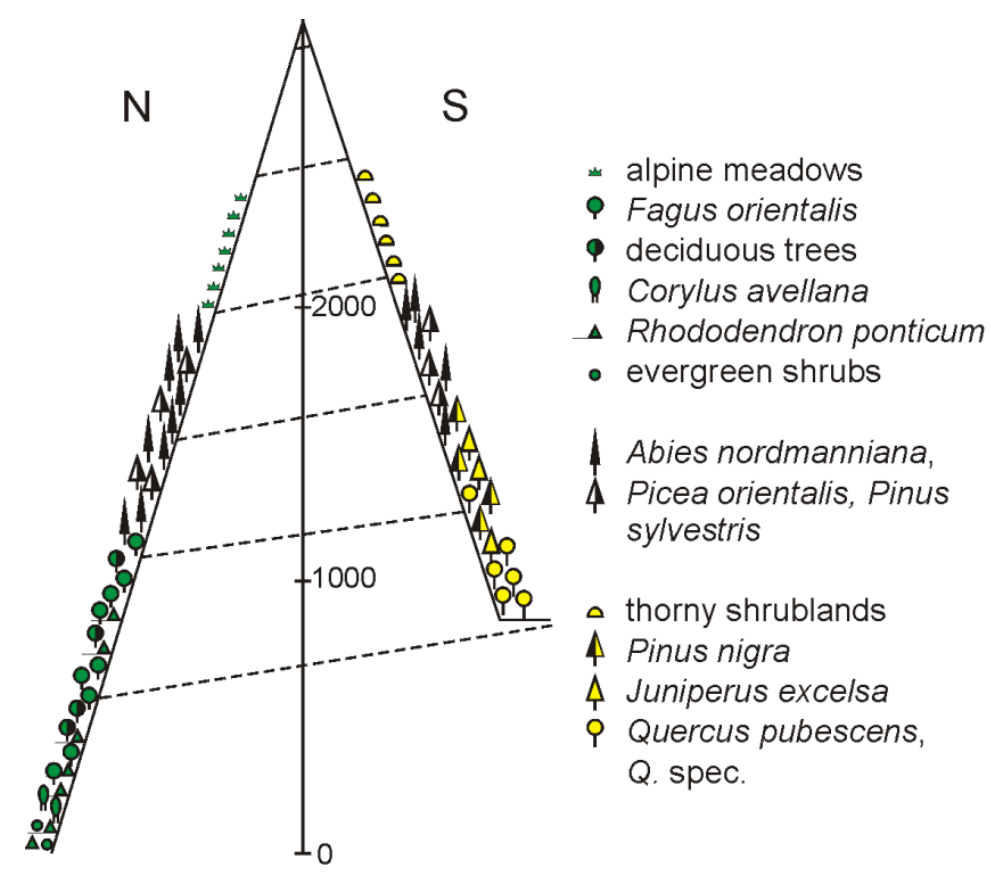

Fig. 3. Simplified vegetation profile across the Pontic Mountains (modified from Mayer and Aksoy, 1986; Kürschner, 1997).

At present, disturbance caused by intensive land use, including wood cutting, livestock breeding and agriculture, have led to the patchy character of the woody vegetation, which is mainly preserved in the mountains and protected areas. Hazel (Corylus) and other fruit trees 
are cultivated in the western and central part of the region from Istanbul to Trabzon, whereas tea grows in the wettest and warmest eastern part and the cultivation of cereals is more typical of inner Anatolia (e.g. Mayer and Aksoy, 1986).

\section{Material and methods}

\subsection{Core stratigraphy and age model}

The uppermost part of the core 22-GC3 presented in the current study consists of three main lithological units (Fig. 4, 5A): (i) a lower Unit III $(47-350 \mathrm{~cm}$ ) composed of lacustrine clays with occasional laminations, (ii) a middle Unit II $(20-47 \mathrm{~cm})$ consisting of a finely laminated sapropel layer, and (iii) an upper Unit I $(0-20 \mathrm{~cm})$ characterized by a finely laminated coccolith ooze layer with a first $(20 \mathrm{~cm})$ and final $(14 \mathrm{~cm})$ coccolith invasion.

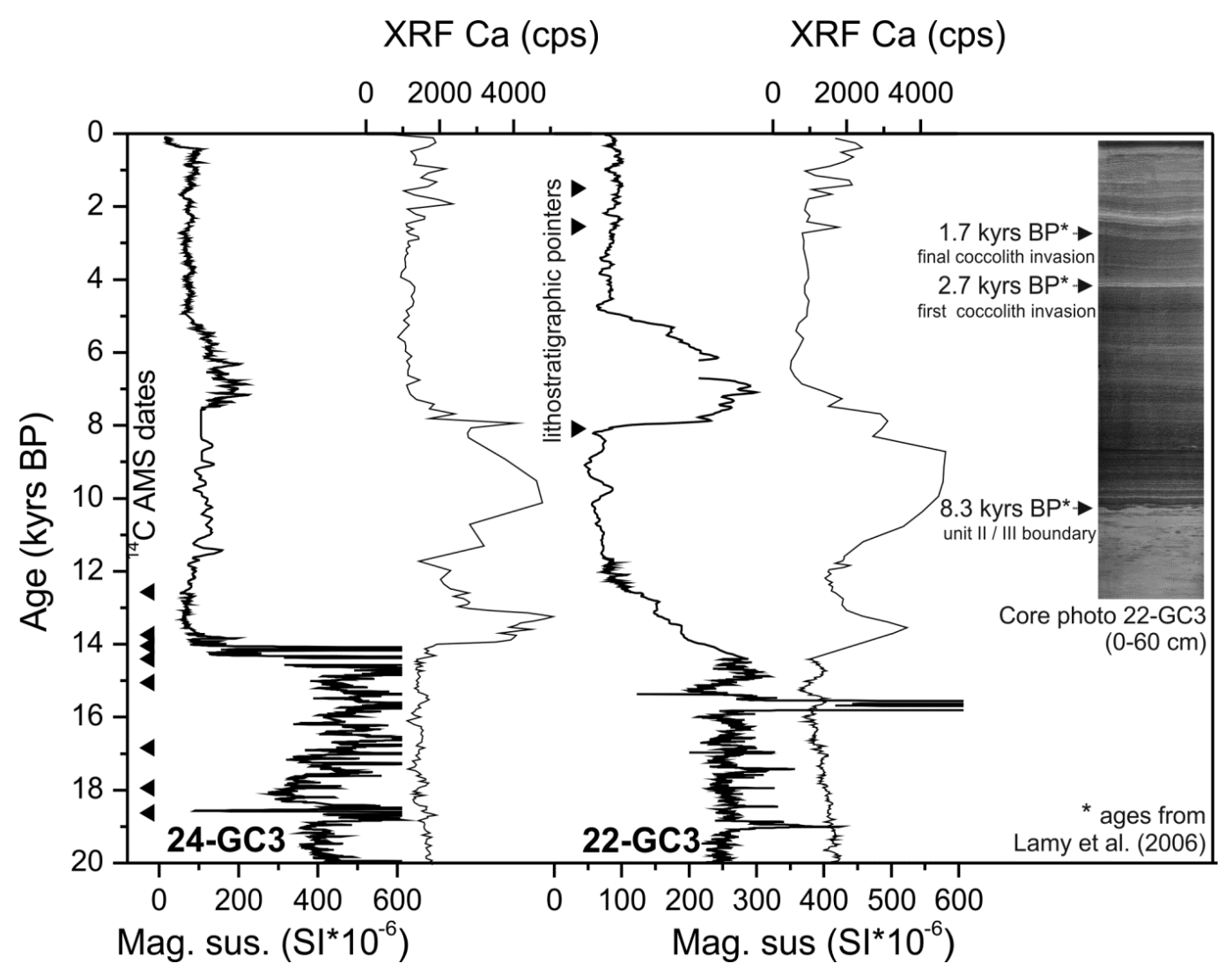

Fig. 4. Correlation between magnetic susceptibility and XRF Ca records of the cores 24-GC3 and $22-\mathrm{GC} 3$ used to transfer the ${ }^{14} \mathrm{C}$ age control points from $24-\mathrm{GC} 3$ to $22-\mathrm{GC} 3$. Top-right inlay shows the 22-GC3 core image for the uppermost $60 \mathrm{~cm}$ of the core indicating the three lithostratigraphic pointers with the respective ages from Lamy et al. (2006). 


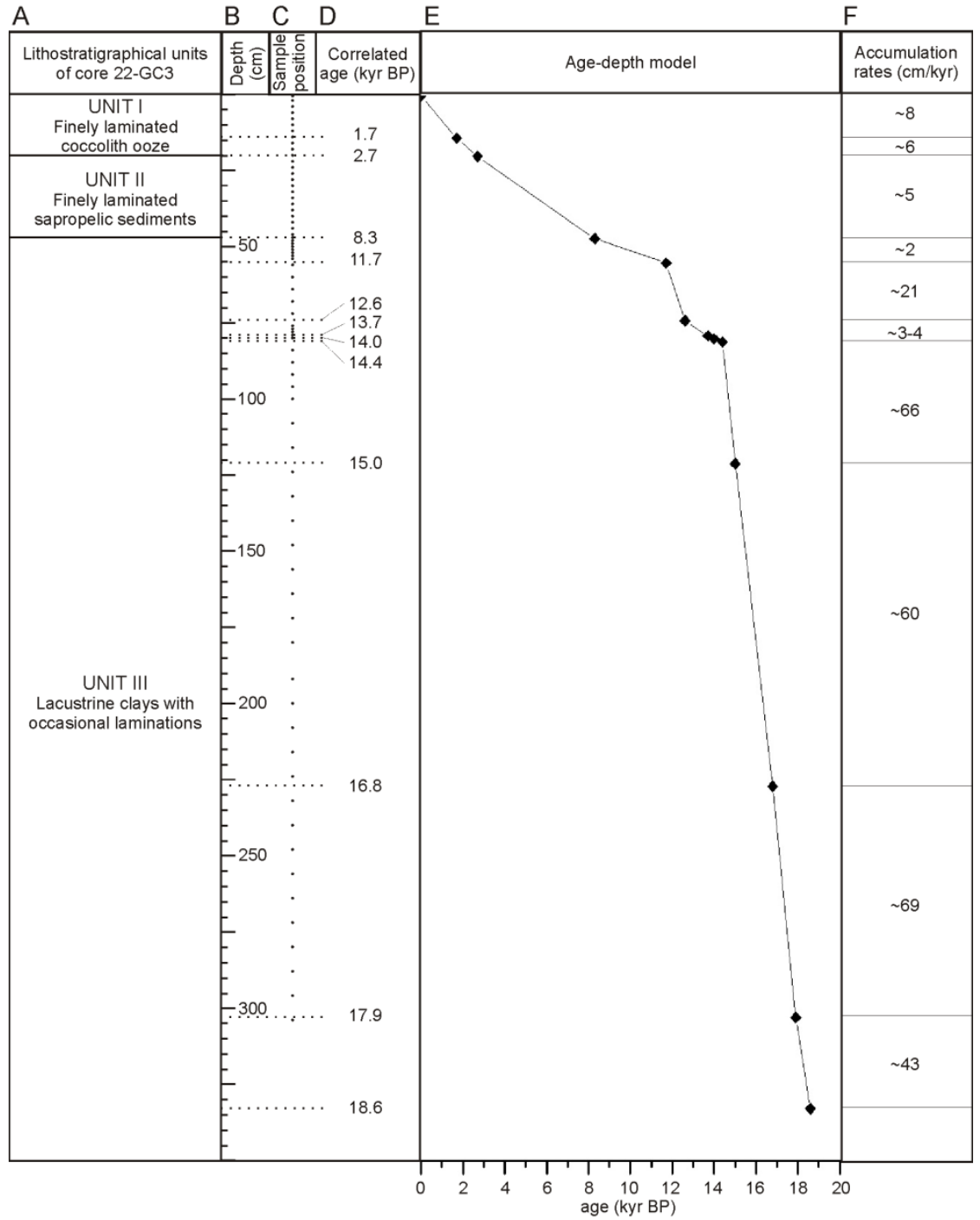

Fig. 5. Lithostratigraphical units of the analysed part of the core 22-GC3 (A) plotted along the core depth (B). Further graphs show (C) depth of samples analysed for pollen and dinocysts, (D) age control points, (E) age-depth model, and (F) changes in accumulation rates.

Because of lack of suitable carbonate material for ${ }^{14} \mathrm{C}$ dating in 22-GC3 and known sensitivity of bulk carbonate and organic carbon to terrestrial contamination (e.g. Jones and Gagnon, 1994; Lamy et al., 2006) we construct the age-depth model for 22-GC3 (Fig. 5E) by correlations with other well-dated Black Sea cores. The lithological units of core 22-GC3 are comparable to the published classical late-glacial and Holocene units of Black Sea sediments (Ross and Degens, 1974; Hay et al., 1991; Lamy et al., 2006). This allows us to correlate different cores from the Black Sea and to construct a chronology for core 22-GC3.

The anchor-points for the upper part of the core 22-GC3 are provided in the Table 3 and Fig. 4 and 5D. Ages for the uppermost $47 \mathrm{~cm}$ were obtained using direct lithological correlation (Fig. 4) with the radiocarbon and Santorini ash dated core GeoB 7622-2 $\left(41^{\circ} 26.70^{\prime} \mathrm{N}, 31^{\circ} 04.00^{\prime} \mathrm{E}\right.$ ) (Fig. 1) (Lamy et al., 2006). Seven ${ }^{14} \mathrm{C}$ accelerator mass spectrometry (AMS) dates was carried out from well preserved larval shells of the shallow- 
marine mollusc Mytilus galloprovincialis and one - from organic matter taken from the interval richest in organic carbon.

Table 3. Stratigraphical control points for sediment core 22-GC3.

\begin{tabular}{|c|c|c|}
\hline $\begin{array}{l}\text { Original depth } \\
\text { (cm) }\end{array}$ & Description & Age (kyrs BP) \\
\hline 0 & surface of the core is assumed to be of modern age & 0 \\
\hline 14 & Unit I, final coccolith invasion, ags from Lamy et al. (2006) & 1.7 \\
\hline 20 & Unit I, first coccolith invasion, age from Lamy et al. (2006) & 2.7 \\
\hline 47 & Unit II / III boundary, age from Lamy et al. (2006) & 8.3 \\
\hline 55 & Basis of Holocene, age from Kwiecien et. al. 2008) & 11.7 \\
\hline 74 & $\begin{array}{l}{ }^{14} \mathrm{C} \text { AMS age from core } 24-\mathrm{GC} 3 \text { linked through magnetic susceptibility and } \\
\text { XRF Ca to } 22-\mathrm{GC} 3\end{array}$ & 12.6 \\
\hline 79 & $\begin{array}{l}{ }^{14} \mathrm{C} \text { AMS age from core } 24-G C 3 \text { linked through magnetic susceptibility and } \\
\text { XRF Ca to 22-GC3 }\end{array}$ & 13.7 \\
\hline 80 & $\begin{array}{l}{ }^{14} \mathrm{C} \text { AMS age from core } 24-\mathrm{GC} 3 \text { linked through magnetic susceptibility and } \\
\mathrm{XRF} \text { Ca to } 22-\mathrm{GC} 3\end{array}$ & 14.0 \\
\hline 81 & $\begin{array}{l}{ }^{14} \mathrm{C} \text { AMS age from core } 24-\mathrm{GC} 3 \text { linked through magnetic susceptibility and } \\
\text { XRF Ca to } 22-\mathrm{GC} 3\end{array}$ & 14.4 \\
\hline 121 & $\begin{array}{l}{ }^{14} \mathrm{C} \text { AMS age from core } 24-G C 3 \text { linked through magnetic susceptibility to } \\
22-G C 3\end{array}$ & 15.0 \\
\hline 227 & $\begin{array}{l}{ }^{14} \mathrm{C} \text { AMS age from core } 24-\mathrm{GC} 3 \text { linked through magnetic susceptibility to } \\
\text { 22-GC3 }\end{array}$ & 16.8 \\
\hline 303 & $\begin{array}{l}{ }^{14} \mathrm{C} \text { AMS age from core } 24-\mathrm{GC} 3 \text { linked through magnetic susceptibility to } \\
\text { 22-GC3 }\end{array}$ & 17.9 \\
\hline 333 & $\begin{array}{l}{ }^{14} \mathrm{C} \text { AMS age from core } 24-\mathrm{GC} 3 \text { linked through magnetic susceptibility to } \\
{ }_{22}-\mathrm{GC} 3\end{array}$ & 18.6 \\
\hline
\end{tabular}

The ${ }^{14} \mathrm{C}$ ages were corrected with a regional deviation from the global reservoir effect of $\sim 70$ years according to the Marine Reservoir Correction Database (Lamy et al., 2006). The anchor points for the marine unit of core 22-GC3 are the transition from Unit III to Unit II at 8.3 kyr BP, as well as the first (2.7 kyr BP) and final (1.7 kyr BP) coccolith invasion (Fig. 4, 5D). The geochronology of the late glacial lacustrine Unit III sediments is based on a sequence of $8{ }^{14} \mathrm{C}$-AMS ages on shells of the bivalve Dreissenia rostriformis (Table 4) from the nearby shallower sediment core $24-\mathrm{GC} 3\left(41^{\circ} 28.66^{\prime} \mathrm{N}, 37^{\circ} 11.68^{\prime} \mathrm{E}, 208 \mathrm{~m}\right.$ water depth) (Fig. 1) that were exported to 22-GC3 through a detailed correlation of high-resolution magnetic susceptibility and XRF Ca intensity measurements on both cores (Fig. 4). The Basis of the Holocene at $55 \mathrm{~cm}$ core depth, as well as the reservoir age correction for the radiocarbon ages were adopted from Kwiecien et al. (2008). The sample ages (Fig. 5C) and changes in sedimentation rate (Fig. $5 \mathrm{~F}$ ) were calculated using linear interpolation between the anchor-points (Fig. 5D). 
Table 4. Radiocarbon dates for $24-\mathrm{GC} 3 .{ }^{14} \mathrm{C}$ ages were converted into calibrated calendar ages before present, defined as AD 1950, using the Calib 6.0 radiocarbon calibration tools with the INTCAL09 calibration curve. Reservoir ages were adopted from Kwiecien et al. (2008).

\begin{tabular}{clcccc}
\hline $\begin{array}{c}\text { Core depth } \\
(\mathrm{cm})\end{array}$ & Lab-ID & $\begin{array}{c}{ }^{14} \text { C age } \\
(\text { kyrsBP })\end{array}$ & 1sigma error & $\begin{array}{c}\text { Reservoir age } \\
\text { (kyrs) }\end{array}$ & $\begin{array}{c}\text { cal }^{14} \mathrm{C} \text { age } \\
(\text { kyrs BP })\end{array}$ \\
\hline 148 & ETH-35501 & 10,595 & 60 & 0.00 & 12.57 \\
187 & ETH-35502 & 12,385 & 65 & 0.50 & 13.74 \\
197 & ETH-35503 & 13,205 & 65 & 1.00 & 14.05 \\
210 & ETH-35504 & 13,330 & 65 & 1.00 & 14.41 \\
240 & ETH-35505 & 13,700 & 65 & 1.00 & 15.05 \\
313 & ETH-35506 & 15,165 & 75 & 1.45 & 16.84 \\
350 & ETH-35507 & 16,245 & 80 & 1.45 & 18.63 \\
391 & ETH-35508 & 16,835 & 85 & 1.45 & \\
\hline
\end{tabular}

3.2. Palynological analysis of pollen, spores and non-pollen palynomorphs

A total of 72 samples were selected for palynological analysis from the upper part of the core 22-GC3 $(0-305 \mathrm{~cm})$, each sample consisting of $1 \mathrm{~cm}^{3}$ of wet sediment. In the upper part of the core, noticeable for its low sedimentation rates (Fig. 5F), the sampling interval was 2 $\mathrm{cm}$ on average (Fig. 5C), while in the lower part characterized by much higher sedimentation rates samples were taken in $8 \mathrm{~cm}$ steps. Conventionally we added one or two tablets of Lycopodium spores (Batch No 177745, consist of 18584 spores) to each sample in order to calculate concentrations (Stockmarr, 1971) of pollen and non-pollen palynomorphs (NPP). The samples for microscopic analysis were prepared using standard methods described elsewhere (Erdtman, 1960; Moore et al., 1999). These included treatment in cold $10 \% \mathrm{HCl}$ to remove carbonates, sieving through a metallic sieve with $150 \mu \mathrm{m}$ mesh size to remove coarse sediment particles, treatment in cold $71-74 \%$ HF over two nights to remove silica minerals, acetolysis (three minutes) to destroy remaining soluble organic tissues, and an ultrasonic bath (1-2 $\mu \mathrm{m}$ mesh size) for the final cleaning. The remaining suspensions stored in glycerine were then used for microscopic analysis. Routine counting was carried out at $400 \times$; in ambiguous cases at $1000 \times$ magnification. The pollen reference collections of the department of Palynology and Climate Dynamics at Georg-August University in Göttingen (Germany) were used for the identification of pollen and spores. We followed the pollen and spore nomenclature of Beug (2004) and Chester and Raine (2001), whereas NPPs were named following van Geel et al. (1989, 2003). In each sample a minimum of 300-350 identifiable pollen grains was counted. The total pollen sum taken as $100 \%$ was then applied for calculation of individual taxon percentages as presented in the pollen diagram (Fig. 6). Relative abundances for spore and NPP taxa were also calculated from the total pollen sum. 
The pollen diagram (Fig. 6) was constructed using C2 (version 1.6.6) software (Juggins, 2003). A $\times 10$ exaggeration of the horizontal scale is used to show changes in low taxa percentages. The diagram was subdivided into local pollen zones (LPZ), using visual inspection taking into consideration major changes in pollen taxa composition and relative abundance, supported by the results of biome score calculation described in the following section 3.3 (see Bezrukova et al., 2010 for discussion of the approach). Additionally, pollen assemblage zones are presented in Table 5.

Regarding the pollen identification, numerous species of oaks growing in northern Anatolia have pollen with very similar morphology that was grouped by Beug (2004) into three different types: 1) Quercus robur-type, including deciduous Quercus petraea, $Q$. pubescens, Q. frainetto, Q. ithaburensis ssp. macrolepis, 2) Quercus cerris-type with deciduous $Q$. cerris, $Q$. trojana and 3) Quercus ilex-type including evergreen $Q$. coccifera, only growing in Anatolia (Mayer and Aksoy, 1986).

In the pollen diagram, taxa are ordered by plant functional types (Prentice et al., 1996): conifers (e.g. Pinus diploxylon-type, Pinus haploxylon-type, Juniperus, Picea, Abies, Cedrus, Taxus), temperate summer-green and evergreen taxa (e.g. Fagus, Carpinus betulus, Ostryatype, Castanea, Tilia, Corylus, Quercus robur-type, Buxus, Hedera helix, Vitis etc.), warmtemperate summer-green (Fraxinus ornus) and sclerophyll Mediterranean tree/shrub taxa (e.g. Olea, Phillyrea, Pistacia, Quercus ilex-type), arid woody shrub taxa (Ephedra fragilis-type, Ephedra distachya-type, Hippophae, Haloxylon) and other non-arboreal taxa (e.g. Artemisia, Chenopodiaceae, Poaceae, Ericaceae, Cyperaceae, Caryophyllaceae). Several rare pollen taxa are not shown on the diagram. Complete data are available under the name of the corresponding author through the PANGAEA server (www.pangaea.de).

Among the NPPs we selected two taxa for display on the diagram (Fig. 6): Glomus-type and Sporormiella-type. The first, chlamydospores of the endomycorrhizal fungus Glomus, are often discussed as an indicator of erosion in the catchment area (e.g. van Geel et al., 2003). The second, Sporormiella-type, is commonly used as indicator for herbivore activity or even density (e.g. van Geel et al., 2003; Davis and Shafer, 2006; Raper and Bush, 2009).

\subsection{Biome reconstruction method}

For purpose of biome reconstructions we assign pollen taxa to plant functional types (Peyron et al., 1998; Tarasov et al., 1998b, 2000) and, based on the plant functional types that contribute to each biome, classifies pollen spectra to one or more biomes following method presented by Prentice et al. (1996) (Table A1). 


\subsection{Analysis of dinoflagellate cysts}

Dinoflagellates are one of the major groups of microplankton, inhabiting marine and fresh water environments (e.g. Dale, 2001b). Dinoflagellates are among the aquatic microorganisms that produce cysts and cause blooms in sea water (e.g. Marret and Zonneveld, 2003). In palaeoecological studies, changes in the concentration of dinoflagellate cysts (=dinocysts) are often used as an indicator of changes in primary productivity mostly in terms of cultural eutrophication (e.g. Dale et al., 1999; Matsuoka, 1999; Dale, 2001a; Matsuoka, 2001; Chmura et al., 2004; Dale, 2009). For the current study, we calculated dinocyst concentration in the core sediment (Fig. 7F, 7G) in order to get an additional proxy for changes in primary productivity of the sea water since the last glacial, and for reconstructing changes from fresh/brackish to saline water environments, which can be traced by changes in the dinocyst assemblages (e.g. Wall et al., 1973; Mudie et al., 2001, 2002b, 2004, 2007; Marret et al., 2009; Verleye et al., 2009).

In the uppermost part of sediment core 22-GC3 $(0-49 \mathrm{~cm})$, which contains sensitive peridinoid dinocysts, samples of $0.5-1 \mathrm{~cm}^{3}$ were laboratory treated using the standard method without acetolysis or an ultrasonic bath (e.g. Marret et al., 2009). The treatment included demineralization with cold hydrochloric acid $(10 \% \mathrm{HCl})$ and cold hydrofluoric acid $(70 \% \mathrm{HF})$ over two nights followed by sieving through a $10 \mu \mathrm{m}$ nylon mesh. To calculate the cyst concentration, one tablet of Lycopodium spores (Batch No 177745, consist of 18584 spores) was added to each sample at the beginning of preparation. In the lower sediments (54-304 $\mathrm{cm}$ ), which contain species resistant to acetolysis (Pyxidinopsis psilata, Spinifrites cruciformis), the dinocyst analysis was carried out using residues prepared for palynological analysis (see 3.2.). Identifications were carried out with the light microscope at $400 \times$ magnification. Dinoflagellate cyst taxonomy is based on Wall et al. (1973), Rochon et al. (1999) and Marret et al. (2004).

For purpose of this paper we present only dinocyst concentrations. Dinocyst concentrations were counted separately for fresh / brackish water indicators (Pyxidinopsis psilata, Spinifrites cruciformis) and marine water indicators (Spiniferites ramosus group, Lingulodinium machaerophorum etc.), separated following the literature (e.g. Wall et al., 1973; Mudie et al., 2001, 2002b, 2004, 2007; Marret et al., 2009; Verleye et al., 2009).

\subsection{XRF scanning}

The sediment from core 22-GC3 was scanned at 1-cm resolution with an AVAATECH X-ray fluorescence (XRF) scanner. The XRF core scanner measures the bulk intensities of 
major elements (e.g. Al, Si, S, K, Ca, Ti, Mn, and Fe) on split sediment cores and gives XRF intensities in total counts (see Jansen et al., 1998; Röhl and Abrams, 2000; Richter et al., 2006 for details of the method). For the purpose of this paper we use only $\mathrm{Ca}$ and $\mathrm{Ti}$ intensities (Fig. 7D, 7E), whilst publication of complete geochemical data of the 22-GC3 core is in preparation. The Ti intensity is usually interpreted as a proxy for terrigenous material supply, whereas the $\mathrm{Ca}$ intensity reflects allogenic and autogenic signals (e.g. Bahr et al., 2005).

\section{Results and discussion}

Presenting and discussing the results of this study, we paid attention to the potential uncertainties inherent in the interpretation of the pollen record from core 22-GC3 (subchapter 4.1). With this in mind, we divide the further results and discussion section into chronological subsections (4.2-4.7), reflecting most prominent environmental changes. We define "Pleniglacial" as interval $~ 18-14.5$ kyr BP, "Late-glacial interstadial complex" - 14.5-12.9 kyr BP, "Late-glacial stadial" - 12.9-11.7 kyr BP, "early Holocene" - 11.7-8.5 kyr BP, “middle Holocene" - 8.5-5 kyr BP, "late Holocene" - 5-0 kyr BP.

\subsection{Potential uncertainties in interpretation of pollen record 22-GC3}

Because the age-depth model for 22-GC3 is constrained by correlation to other records, there is a danger that errors in the age model of one of the other records will carry through to this record also. This would have an impact on the interpretation of the results. For this reason we try to avoid discussions about timing of changes in terms of absolute dates and focus more on the relative timing of changes between different records from core 22-GC3.

One of other uncertainties is evaluation of the pollen source area contributing to the sediment at the coring site. Indeed, the large surface and catchment area of the Black Sea, substantial river run-off, sea currents and winds, mountainous terrain, and mosaic vegetation (Fig. 1, 2, 3) may influence pollen transport and accumulation, and complicate the interpretation of the fossil record. Palynological studies of deep-water oceanic, marine and large lake sediments (e.g. Groot and Groot, 1966; Desprat et al., 2005; Demske et al., 2005; Hooghiemstra et al., 2006) demonstrate that the vegetation from coastal areas which are nearest to the coring site contributes most of the pollen grains to the surface and fossil sediment. For the Black Sea, this was proved by Shatilova (1974), who analysed pollen distribution in the modern marine sediments along the Georgian coasts and demonstrated close correspondence of the recent pollen assemblages with the modern vegetation of the Colchic Lowland. Taking into account the proximity of the 22-GC3 coring site to the northern 
Anatolian coast (Fig. 1), the pattern of the sea current around the site (Fig. 2) and the composition of the topmost pollen spectrum of the 22-GC3 record (Fig. 6) we assume northern Anatolia and particularly the northern slopes of the Pontic Mountains to be the main pollen source area for the study site.

Another important (although methodologically complex) task of pollen analysis in regions with a long human occupation is to reconstruct human impact on the local and regional environments. Analysing the core 22-GC3 sediment, we also looked for a possibility to distinguish between the natural trends and human-induced changes in the vegetation, and therefore paid special attention to pollen taxa that could be counted as anthropogenic indicators (Behre, 1990). However, an interpretation of human impact in the pollen records from the Near East and eastern Mediterranean is, like in other steppe regions of Eurasia, rather difficult (e.g. Schlütz et al., 2008; Miehe et al., 2009; Schlütz and Lehmkuhl, 2009; Lehmkuhl et al., 2011). Primary (i.e. crop plants) and secondary (i.e. Plantago lanceolata, Sanguisorba minor-type, Poaceae, Brassicaceae, Chenopodiaceae) human-indicators, which are successfully used in Central and Northern Europe (Behre, 1990), are part of the natural vegetation there. Even the transformation of woodland to open (steppe) landscape might have a natural origin and be caused largely by climatic factors. The group of secondary anthropogenic indicators in the pollen records from the eastern Mediterranean include Quercus calliprinos-type (treated as Q. ilex-type in our study), Juniperus, Castanea sativa, Juglans regia, Fraxinus ornus, Olea europea, accompanied by Plantago lanceolata, Sanguisorba minor-type, and Platanus (Zeist et al., 1975; Bottema and Woldring, 1990; Vermoere et al., 2002). These pollen types, indicating a rich arboriculture as well as a pastoral economy, were assigned to the Beyşehir Occupation Phase (BOP), a cultural phase seen in palynological diagrams of south-western Turkey from roughly $3500 \mathrm{yr}$ BP to $1300 \mathrm{BP}$ (Zeist et al., 1975; Bottema and Woldring, 1990; Vermoere et al., 2002).

Sporormiella-type is usually interpreted as a possible proxy of herbivore biomass (e.g. van Geel et al., 2003; Davis and Shafer, 2006; Mudie et al., 2011). However, since Sporormiella-like-spores are produced by species of the coprophilous genus Sporormiella, but also by facultative coprophilous Preussia and saprobic on grasses Ohleriella (e.g. Zhang et al., 2011), careful use of this spore type is strictly recommended. Regarding marine archives, appearance of Sporormiella-type is suggested mainly to reflect terrestrial input (by air and/or water) of eroded decayed organic matter (grass or dung) into marine system. 


\subsection{Late Pleniglacial ( $18-14.5 \mathrm{kyr} B P)$}

This time interval between the end of the LGM phase and the Termination I in the 22GC3 pollen record (Fig. 6, Table 5) is represented by the lowermost pollen zone LPZ 22GC3$7(305-91 \mathrm{~cm})$. The pollen spectra demonstrate highest percentages of herbaceous taxa (>80\%), mainly Artemisia (37-66\%) and Chenopodiaceae (12-24\%). Arboreal taxa (7-23\%) are mainly represented by eurythermic conifers, including Pinus diploxylon-type and Juniperus. Among temperate summer-green woody taxa, only Quercus robur-type shows permanent presence in the pollen assemblages. The other taxa of this plant functional type (PFT) and in the present-day Euxinian and Mediterranean forests appear in the pollen spectra, but rarely and discontinuously. By contrast, pollen of Ephedra (desert shrub PFT in Prentice et al., 1996) and Hippophae are constantly present. Spores of Glomus and Sporormiella-type are recorded for this zone (Fig. 6) and dynocyst concentrations are very low (Fig. 7G).

The pollen data show the dominance of the Artemisia-steppe in the region south of the coring site, suggesting rather dry environments during that time. However, the aridity of the glacial climate was not extreme, as indicated by high percentages of grass pollen, the presence of arboreal vegetation and the relatively minor contribution of Ephedra. The presence of Ephedra fragilis-type pollen (a taxon characteristic of the arid subtropical and tropical regions) might indicate that mean temperatures at sea level of the warmest month were still rather high (Tarasov et al., 1998a). On the other hand, the continuous presence of temperate summer-green tree taxa and the presence, albeit discontinuous, of warm-temperate summergreen tree taxa suggest that mean temperatures of the coldest month were warmer than $-15^{\circ} \mathrm{C}$ but somewhat colder than $-2^{\circ} \mathrm{C}$ (Prentice et al., 1996). The results of quantitative biome reconstruction (Fig. 6, 7I, 7J) complement the qualitative interpretation of the pollen record. Reconstructed scores of the steppe biome (Fig. 7J) are highest in the record ( 14-19), suggesting that steppe vegetation predominated in the region. Scores of the temperate deciduous forest biome (Fig. 7I), although low ( 2-7), nevertheless suggest the presence of woody vegetation in the region. The isolated forest patches dominated by pines, junipers and oak trees scattered in the open landscape most likely occupied lowlands and valleys crossing the Pontic Mountains and opening towards the Black Sea. 


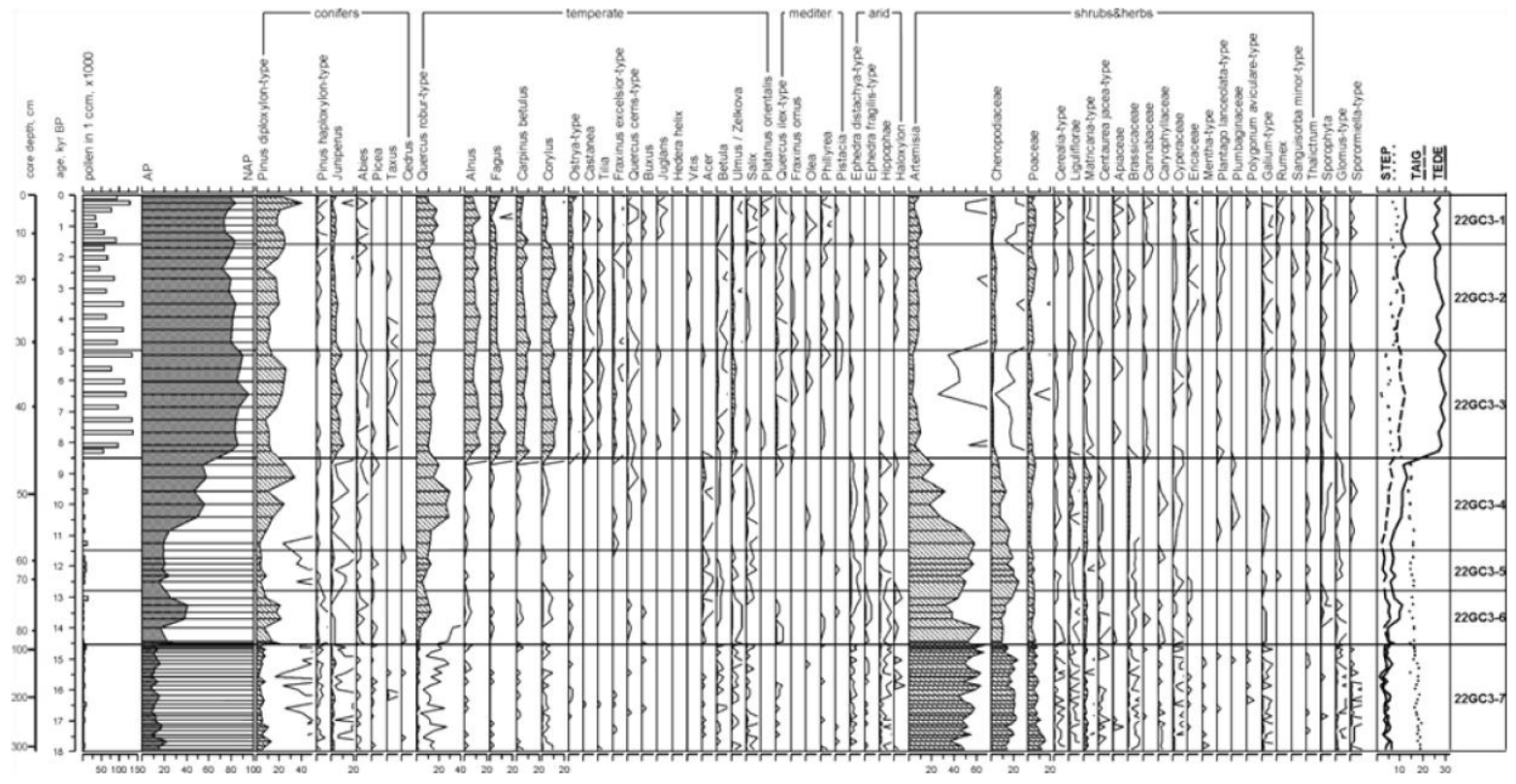

Fig. 6. Simplified pollen percentage diagram and calculated biome scores for selected biomes from the analysed part of the core $22-\mathrm{GC} 3$. A $\times 10$ exaggeration of the horizontal scale is used to show changes in low taxa percentages.

Our interpretation corroborates the vegetation reconstruction based on the marine core 2345 pollen record, from the western part of the Black Sea (Filipova-Marinova, 2006b), and on the terrestrial pollen records from lakes in northern (Bottema et al., 1995), central and east Anatolia (Bottema and Woldring, 1984; Litt et al., 2009), which all reveal dominant steppe vegetation reflecting a colder and drier-than-present climate during the Pleniglacial.

The pollen data from the Aegean Sea (Kotthoff et al., 2008) and particularly the terrestrial pollen record from Tenaghi Philippon in north-western Greece (Müller et al., 2011) reveal relatively high contents of arboreal pollen (mainly Pinus with some admixture of deciduous Quercus, Juniperus, Betula, Corylus, Tilia and Ulmus) around 15-21 kyr BP, possibly reflecting similar, or even wetter, and more variable conditions in the Aegean region in comparison to the 22-GC3 record. Different moisture conditions could be explained by differences between the main moisture sources. During the glacial period the shift of the westerly jet towards the equator (Chapman and Maslin, 1999) would have led to more pronounced dry conditions in central and northern Europe and relatively wet conditions in the Mediterranean (Kwiecien et al., 2009) including the Aegean region. At present, the northern slopes of the Pontic Mountains receive moisture mainly from the Black Sea (e.g. Badertscher et al., 2011). During the glacial period, low temperatures caused relatively low evaporation from the Black Sea surface that together with the decreased moisture from the Atlantic Ocean resulted in a relatively dry climate and vegetation in northern Anatolia. 
In order to approximately quantify the climatic conditions in northern Anatolia at $\sim 18$ kyr BP, we consider quantitative reconstructions of the Pleniglacial climate and vegetation in the study region. Pollen-based climatic reconstructions performed for several sites from the Mediterranean region (Peyron et al., 1998) revealed a much lower-than-present mean temperature of the coldest month (by $15 \pm 5^{\circ} \mathrm{C}$ ) and the year (by $10 \pm 5^{\circ} \mathrm{C}$ ) about $18 \mathrm{kyr} \mathrm{BP}$ as well as $20 \%$ lower available moisture, with a precipitation anomaly of $-600 \pm 200 \mathrm{~mm} / \mathrm{yr}$. The climate reconstruction for the sites from Georgia (Tarasov et al., 1999), which are geographically and climatically close to the area represented by the 22-GC3 pollen record, suggests that during the LGM the mean temperature of the coldest month varied from $-8^{\circ}$ to $4^{\circ} \mathrm{C}$, the mean temperature of the warmest month was around $17-20^{\circ} \mathrm{C}$ and precipitation varied from $\sim 300 \mathrm{~mm} / \mathrm{yr}$ at low-elevation sites to $\sim 650-750 \mathrm{~mm} / \mathrm{yr}$ at higher-elevation sites. Colder and dryer conditions result in a wide spread of the herbaceous vegetation (cool steppe, tundra) in Mediterranean (Tarasov et al., 1998b) and around the Black Sea (Tarasov et al., 1999). Similar to pollen record of 22-GC3, biome reconstructions reveal presence of forest biomes (including cool mixed, cool conifer and taiga forest) in the western Caucasus and on the coast of the Sea of Azov, suggesting that forest vegetation could survive the coldest and driest phase of the last glacial in the locally favourable environments (Tarasov et al., 1999).

The well-known hemispheric trend of warming at the end of Heinrich Event 1 (Svensson et al., 2008) had a pronounced hydrological impact in the subtropical north-east Atlantic (Bard et al., 2000) and caused an increase in sea-surface temperature in the western Mediterranean (Cacho et al., 2000), melt-water pulses and a possible connection of the Black Sea with the Caspian Sea (Badertscher et al., 2011), and 'red layer' deposition through the change of the dominant sediment source as a response to reorganization of atmospheric/oceanic circulation (Kwiecien et al., 2009). The melt-water pulse (MWP) is clearly demonstrated by a depletion of $\delta^{18} \mathrm{O}$ values in isotope records of stalagmite So-1 from the Sofular Cave (Fig. 7B) in the western Pontic Mountains (Fig. 1), and from the combined Black Sea $\delta^{18} \mathrm{O}$ record (Fig. 7C) at $\sim 16.1-14.5 \mathrm{kyr}$ BP. Except for a slight increase in TEDE biome scores (Fig. 7I) after $\sim 15.4 \mathrm{kyr}$ BP, which could be considered as an indicator of wetter/warmer conditions, the 22-GC3 pollen record, including the AP curve (Fig. 7H), shows very weak responses of regional vegetation to the climate change. These are better expressed in more negative $\delta^{13} \mathrm{C}$ values from Sofular Cave (Fig. 7K), usually interpreted as the spreading of C3 plants, more dense vegetation and enhanced soil productivity through the onset of warmer and more humid conditions (Fleitmann et al., 2009). 


\subsection{Late-glacial interstadial complex $\sim 14.5-12.9 \mathrm{kyr} B P$}

LPZ 22GC3-6 $(91-75 \mathrm{~cm})$ demonstrates a sharp increase in arboreal taxa percentages, up to $41 \%$ in the middle of this zone (Fig. 6, Table 5). The first increase in Pinus diploxylontype up to $20 \%$ is registered around $14.5 \mathrm{kyr}$ BP and the peak (14\%) in Quercus robur-type appears around $13.5 \mathrm{kyr}$ BP. These are separated by an interval with a short-term increase in Artemisia, which still remains the dominant taxon (32-63\%). Spores of mosses and ferns are registered in the upper half of this zone. The biome reconstruction demonstrates an increase in temperate deciduous forest biome scores (Fig. 7I) with two peaks in TEDE reflecting an increase in AP percentages (Fig. 7H). However, steppe biome still has the highest scores ( 14-16) and remains the dominant vegetation type (Fig. 7J). Observed changes in the pollen composition and in reconstructed biome scores suggest a rise in temperature and precipitation, which caused the spread of forest patches with a significant contribution of pines and oaks in the Pontic Mountains.

The late-glacial interstadial complex, which corresponds to the Meiendorf/Bølling/Allerød (MBA) interstadial complex in the terrestrial pollen records from Central Europe (see Litt et al. (2003) for discussion and references) and to the Greenland interstadial (GI) 1 of the $\delta^{18}$ O NGRIP record (Svensson et al., 2008) (Fig. 7A), is clearly reflected in the 22-GC3 pollen diagram (LPZ 22GC3-6) by higher percentages of arboreal pollen (Fig. 6, 7H).

Table 5. Table of the Pollen Assemblage / Abundance Zones.

\begin{tabular}{|c|c|c|}
\hline $\begin{array}{l}\text { Pollen } \\
\text { Zone }\end{array}$ & Assemblages (minimum - maximum \%) & $\begin{array}{l}\text { Period } \\
(\text { kyr BP) }\end{array}$ \\
\hline 22GC3-1 & Pinus (18-40\%) - Quercus (10-19\%) - Alnus (7-14\%) - Artemisia $(5-12 \%)$ & $0-1.6$ \\
\hline 22GC3-2 & $\begin{array}{l}\text { Pinus }(7-24 \%)-\text { Quercus }(12-22 \%)-\text { Alnus }(7-14 \%)-\text { Corylus }(5-13 \%)- \\
\text { Artemisia }(6-12 \%)-\text { Carpinus betulus }(5-12 \%)\end{array}$ & $1.6-5$ \\
\hline $22 \mathrm{GC} 3-3$ & $\begin{array}{l}\text { Pinus }(8-27 \%)-\text { Quercus }(11-18 \%)-\text { Alnus }(8-14 \%)-\text { Fagus }(6-14 \%)-\text { Corylus } \\
(6-13 \%)-\text { Carpinus betulus }(6-11 \%)-\text { Juniperus }(2-11 \%)\end{array}$ & $5-8.5$ \\
\hline 22GC3-4 & $\begin{array}{l}\text { Artemisia }(11-48 \%) \text { - Quercus }(13-30 \%) \text { - Pinus (8-34\%) - Chenopodiaceae (7- } \\
17 \%)\end{array}$ & $8.5-11.5$ \\
\hline $22 \mathrm{GC} 3-5$ & $\begin{array}{l}\text { Artemisia (44-58\%) - Chenopodiaceae (14-25\%) - Quercus (6-13\%) -Pinus (4- } \\
9 \%)\end{array}$ & $11.5-12.8$ \\
\hline $22 \mathrm{GC} 3-6$ & $\begin{array}{l}\text { Artemisia }(32-63 \%) \text { - Pinus (7-22\%) - Quercus (2-14\%) - Chenopodiaceae (11- } \\
12 \%)\end{array}$ & $12.8-14.53$ \\
\hline 22GC3-7 & $\begin{array}{l}\text { Artemisia }(36-66 \%) \text { - Chenopodiaceae }(11-24 \%) \text { - Poaceae }(5-16 \%) \text { - Pinus }(2- \\
13 \%)\end{array}$ & $18-14.53$ \\
\hline
\end{tabular}

The Pinus percentage peak at $\sim 14.5 \mathrm{kyr}$ BP coincides with a prominent increase in $\delta^{13} \mathrm{C}$ values from the Sofular Cave dated to $\sim 14.7-14.25 \mathrm{kyr}$ BP (Fig. 7K), indicating a significant increase in available moisture in northern Anatolia. Both records correlate to GI 1e, suggesting a synchronous response of the region to the warming in the North Atlantic. The 
regional increase in Pinus pollen percentages was also detected in the core 2345 record from the western Black Sea (Filipova-Marinova, 2006b) and in the northern Anatolian pollen record from Yenicağa Lake (Bottema et al., 1995). In the SL 152 pollen record from the Aegean Sea, the onset of the MBA interstadial complex is indicated by a prominent increase in deciduous Quercus percentages (Kotthoff et al., 2008).

Considering hydrological changes, primary productivity in the Black Sea increased already from $\sim 14.7 \mathrm{kyr} \mathrm{BP}$, as indicated by a slow but steady increase in the concentration of dinocysts during $~ 14.7-14.3 \mathrm{kyr}$ BP (Fig. 7G), in line with a temperature increase at the beginning of GI 1e. Comparison of different proxies from the core 22-GC3 shows a delayed increase in Ca precipitation at the beginning of GI 1e (Fig. 7E), which can be explained by a mixed authigenic and allogenic nature of $\mathrm{Ca}$ in the sediment. While allogenic $\mathrm{Ca}$ depends on terrigenous supply, authigenic carbonate precipitation is a typical process in lakes, and is caused by $\mathrm{CO}_{2}$ assimilation and $\mathrm{pH}$-increase through intensified phytoplankton blooms during warm periods (Bahr et al., 2005 from Leng and Marshall, 2004). Prior to 14.5 kyr BP, Ca and Ti curves in core 22-GC3 (Fig. 7D, 7E) proceed in parallel, which indicates a mostly terrigenous origin of $\mathrm{Ca}$. A sharp decline in $\mathrm{Ti}$ at $\sim 14.4 \mathrm{kyr}$ BP coincides with an increase in arboreal pollen percentages (and in vegetation cover density) causing a decrease in melt-water and surface run-off. The switch from primary terrigenous to primary authigenic $\mathrm{Ca}$ origin started after $\sim 14.2-14 \mathrm{kyr}$ BP with the beginning of GI 1a-c and took $\sim 500 \mathrm{yr}$ after the beginning of warming suggested by other proxies.

The interval $\sim 14.2-14 \mathrm{kyr}$ BP experienced relatively cool and dry conditions, as suggested by low arboreal pollen values (Fig. 7H), and thus can be correlated to GI $1 \mathrm{~d}$ in the NGRIP ice core (Fig. 7A). The impact of cooler/drier conditions on vegetation cover is also clearly visible in more positive $\delta^{13} \mathrm{C}$ values from the Sofular Cave (Fig. 7K), lower dinocyst concentrations (Fig. 7G), and in the regional marine (Filipova, 2006b; Kotthoff et al., 2008) and terrestrial pollen data (Bottema et al., 1995) from the eastern Mediterranean.

The interval from $\sim 14$ to $\sim 12.9 \mathrm{kyr}$ BP is characterized by relatively high TEDE biome scores (Fig. 7I) and by a corresponding decrease in $\delta^{13} \mathrm{C}$ values from the Sofular Cave (Fig. $7 \mathrm{~K})$. Similar to other high-resolution pollen records in Europe and eastern Mediterranean (e.g. Litt et al., 2003; Kotthoff et al., 2008; Litt et al., 2009), the pollen record from 22-GC3 clearly indicates GI 1a-c in the NGRIP ice core (Fig. 7A). During GI 1a-c, the further spread of forests in northern Anatolia is reflected by an increase in Quercus, Corylus, Ulmus and Abies pollen percentages, indicating warmer and wetter environments than during the earlier interval. The regional open forests were dominated by pines and oaks, with some elm and 
hazel at lower altitudes and birches and firs at higher altitudes. An increase in available moisture in the study region is indicated by the spread of woody taxa (particularly temperate/boreal conifers) and by the more regular occurrence of fern and moss spores in the 22-GC3 record (Fig. 6). Warming in northern Anatolia during GI 1a-c can be seen in the proxies representing terrestrial environments, including pollen, isotopes (Fig. $7 \mathrm{H}-\mathrm{J}$ ) and Ti concentrations (Fig. 7E). A similar trend is suggested by an increase in Ca values (Fig. 7D), reflecting more autogenic $\mathrm{Ca}$ precipitation due to a rise in the primary productivity of the Black Sea, also indicated by high concentration of dinoflagellate cysts (Fig. 7G).

\subsection{Late-glacial stadial ( 12.9-11.7 kyr BP)}

Pollen data of LPZ 22GC3-5 $(75-53.5 \mathrm{~cm})$ reveal an abrupt decrease in arboreal taxa percentages, mainly due to a decrease in Pinus diploxylon-type percentages (Fig. 6, Table 5). Quercus robur-type pollen percentages decrease slightly at the bottom of the zone and later increase again. Pollen of euxinian elements are rare, likely indicating climate cooling, particularly during the winter. Herbaceous taxa, mainly Artemisia and Chenopodiaceae, increase up to $85 \%$. Biome reconstruction shows a decrease in TEDE biome scores, while STEP scores remain stable at a high level ( 14-16), suggesting that steppe remained the dominant biome and the total area occupied by woody vegetation decreased in comparison to the interstadial. The stadial climatic oscillation is clearly indicated by all analysed proxies, which point to reduced vegetation cover (Fig. $7 \mathrm{H}$ ), and increased soil erosion and terrigenous supply, indicated by high $\mathrm{Ti}$ values (Fig. 7E). They also point to decreased primary production due to the lowering of summer sea-surface temperature, indicated by a decrease in Ca precipitation (Fig. 7D) and in dinoflagellate cyst concentrations (Fig. 7G).

Bottema (1995), discussing patterns of vegetation development in the eastern Mediterranean during the Younger Dryas, noted that pollen records from northern Anatolia and eastern Greece all demonstrate the spread of herbaceous communities and the retreat of arboreal vegetation, reflecting increased climate aridity in the region. The same conclusion can be derived from the 22-GC3 record, in which percentages of Artemisia, Chenopodiaceae and Ephedra pollen are almost as high as during the Pleniglacial interval, prior to $14.5 \mathrm{kyr}$ BP (LPZ 22GC3-7). However, the Younger Dryas in the northern Anatolia was definitively not as dry and cold as during the Pleniglacial interval. Relatively high percentages of deciduous Quercus (6-13\%) (Fig. 6) and TEDE biome scores (Fig. 7I) support this interpretation, in line with the other recently published high-resolution palaeobotanical records from central Europe (e.g. Kossler, 2010) and northern and eastern Asia (e.g. Stebich et al., 2009; Tarasov et al., 
2009; Bezrukova et al., 2010; Müller et al., 2010; Litt et al., 2009). The $\delta^{13} \mathrm{C}$ record from the Sofular Cave (Fig. 7K) also supports the relatively mild scenario of the Younger Dryas.

However, the reconstruction of the Younger Dryas environments in the northern borderlands of the Aegean Sea derived from the SL152 marine pollen record suggests it was the driest interval of the past $20 \mathrm{kyr}$ (Kotthoff et al., 2008). Their conclusion is based on the fact that pollen of the semi-desert Ephedra (mainly Ephedra distachya-type) reaches a maximum of $25 \%$ at $\sim 11.9 \mathrm{kyr}$ BP. Evidence that the Younger Dryas was dryer than the Pleniglacial, however, does not appear in the terrestrial pollen records from the region, including Tenaghi Philippon (Müller et al., 2011). The latter record demonstrates a decrease in eurythermic conifer (i.e. Pinus) pollen percentages during the Younger Dryas, but relatively high percentages of deciduous and evergreen Quercus pollen, suggesting rather warm winter and summer temperatures and relatively high evaporation losses (i.e. higher than during the Pleniglacial). A plausible explanation for the disagreement between the records from the Aegean Sea and the Black Sea regions might involve changes in the wind and circulation regimes. Climate modelling experiments (e.g. Kutzbach et al., 1993) suggest a shift of the summer westerly jet from the Mediterranean Sea region to a more northerly position between 18 and $12 \mathrm{kyr} \mathrm{BP}$, in response to the decrease in ice volume and the increase in insolation. This change would positively affect the moisture balance of the Black Sea region, including the northern and western slopes of the Pontic Mountains, as suggested by the records.

One of the challenging questions in the regional vegetation development during the Younger Dryas remains the significant decline in pine pollen percentages and the rather weak reaction of oaks (e.g. Kotthoff et al., 2008; Müller et al., 2011; this study). Kotthoff et al. (2008) interpreted the decrease in Pinus percentages through direct elimination of pines growing in coastal areas by a rapid rise in sea level. However, such an explanation might not be enough to account for changes in the Black Sea region, where the first increase in sea level had already occurred during the melt-water pulse around 16 kyr BP (Badertscher et al., 2011). An alternative hypothesis of vegetation distribution in southern Europe (Beug, 1967b, 1977) suggested that during the glacial colder and drier conditions trees could grow in the altitudinal belt between 500 and $800 \mathrm{~m}$. Higher altitudes were too cold for tree growth and lower altitudes were too dry with the exception of river valleys and lake terraces. In the modern natural vegetation of inner Anatolia (Fig. 2 and 3) pine trees represent the upper tree line with low temperatures, whereas oak and juniper trees mark the lower tree line under dry conditions (e.g. Mayer and Aksoy, 1986). Regarding tree lines in Northern Anatolia, Younger 
Dryas pine reduction is related to upslope migration of pines during the Bølling/Allerød warming / humidity increase, their displacement in the middle mountain belt by oaks and damage to pine populations in the upper mountains by a sudden onset of cool / dry climate conditions in the Younger Dryas.

\subsection{Early Holocene ( 11.7-8.5 kyr BP)}

The early Holocene time interval in the 22-GC3 pollen record (Fig. 6, Table 5) is represented by the pollen zone LPZ 22GC3-4 (53.5-48.5 cm). A marked increase in arboreal pollen from 25 to $55 \%$ occurs prior to $\sim 10 \mathrm{kyr}$ BP. The main arboreal pollen taxa remain Quercus robur-type and Pinus diploxylon-type, representing deciduous oaks and pines. Pollen of euxinian and Mediterranean taxa, and spores of mosses and ferns appear more often, suggesting warming / humidity increase of the regional climate. Percentages of herbaceous taxa decrease in abundance, indicating the onset of wetter conditions. The biome reconstruction demonstrates an increase in TEDE scores to $\sim 12$, suggesting a recovery of forest communities with a significant contribution of oaks and pines. Scores of the STEP biome show a decrease $(\sim 14)$, indicating that steppe communities still played an important role in the regional vegetation during the early Holocene. The early Holocene increase in woody cover coincides well with more negative $\delta^{13} \mathrm{C}$ values (Fig. 7K).

The relatively open character of the landscape, which could be similar to modern vegetation in central Anatolia (Fig. 2, 3), and still high erosion processes are indicated by occasional occurrence of Sporormiella-type and permanent presence of Glomus-type. The latter statement seems to contradict the lower Ti values (Fig. 7E), reflecting decrease of terrestrial supply. As a possible explanation for this contradiction we suggest differences in source areas of $\mathrm{Ti}$, as a main component of clays in sediment transported by winds from relatively wide areas, and of fungal spores, possibly reflecting surface erosion of narrow coastal areas. Dinocyst concentrations (Fig. 7G) and Ca intensity (Fig. 7D) reflect the increase in primary productivity synchronously with reconstructed changes in vegetation. 


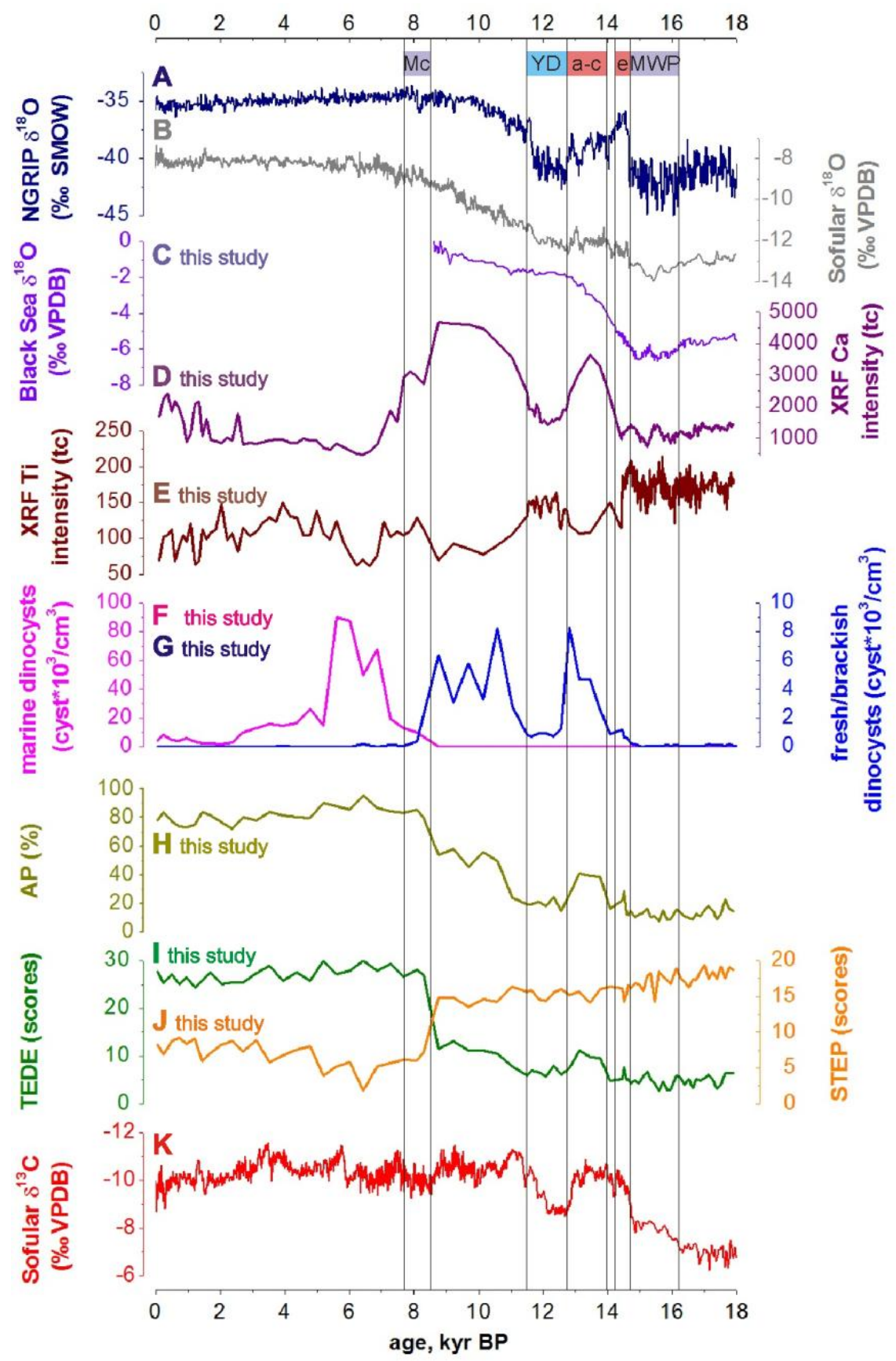

Fig. 7. Diagram summarizing key proxies from the Black Sea region, eastern Mediterranean and North Atlantic discussed in the text: (A) $\delta^{18} \mathrm{O}$ record from the NGRIP ice core (Svensson et al., 2008); (B) $\delta^{18} \mathrm{O}$ record from the Sol stalagmite from the Sofular Cave (Badertscher et al., 2011); (C) combined $\delta^{18} \mathrm{O}$ record from Black Sea sediment cores (this study); (D) Ca and (E) Ti intensity from XRF scanning of the core 22-GC3 (this study); (F) concentration of marine and $(\mathrm{G})$ fresh/brackish dinocysts in $1 \mathrm{~cm}^{3}$ of the 22-GC3 core sediment (this study); (H) arboreal pollen percentages (AP) in the 22-GC3 record (this study); numerical scores of (I) temperate deciduous forest (TEDE) and (J) steppe (STEP) biomes (this study); and (K) $\delta^{13} \mathrm{C}$ record from the Sofular Cave (Fleitmann et al., 2009). Mc indicates opening of the Mediterranean-Black Sea corridor, YD - Younger Dryas, a-c and e - stages of the Greenland Interstadial 1 (GI 1) as defined in Svensson et al. (2008), MWP - melt-water-pulse (after Badertscher et al., 2011). 
The transition to the Holocene is well reflected by the regional pollen records. The relatively quick spread of forest vegetation in different areas within the eastern Mediterranean region indicates variable but generally short distances from their late-glacial refugia. Oak dominated forests spread in the western part of the Black Sea (e.g. Filipova-Marinova, 2006b), in the Aegean Sea region (e.g. Kotthoff et al., 2008) and in eastern (Litt el al., 2009) and northern Anatolia (e.g. Bottema et al., 1995; this study). Pollen records from more continental central Anatolia demonstrate the spread of oak forests with Pistacia (e.g. Roberts et al., 2001), whereas in eastern Anatolia Pistacia forests play a greater role at that time (e.g. Wick et al., 2003; Litt et al., 2009). The pollen diagrams from the relatively humid Caucasus region reveal higher percentages of Abies, Carpinus, Fagus and Alnus, (e.g. Arslanov et al., 2007; Connor and Kvavadze, 2008; Shatilova et al., 2011), suggesting the spread of temperate deciduous and cool mixed forests.

\subsection{Middle Holocene ( 8.5-5 kyr BP)}

The middle Holocene is represented by LPZ 22GC3-3 $(48.5-31 \mathrm{~cm})$. This pollen zone (Fig. 6, Table 5) reveals a marked increase in pollen concentrations (up to 135,000 grains per $1 \mathrm{~cm}^{3}$ ), the dominance of arboreal pollen taxa (up to 95\%) and the dominant role of Fagus, Carpinus betulus, Corylus, Alnus, Tilia, Castanea and other euxinian and Mediterranean elements. Herbaceous taxa pollen percentages are low and Glomus spores are infrequent.

Pollen spectra (Fig. 6) indicate rapid spreading of temperate deciduous forests in northern Anatolia at $~ 8.3$ kyr BP. The development of euxinian forests, including Fagus, Carpinus betulus, Alnus and Corylus with their characteristic elements, such as Hedera helix and Taxus, indicates establishment of the natural vegetation similar to that at present, including species-rich warm mixed and temperate deciduous forests in the low elevation belt, temperate-deciduous beech-hornbeam forests in the middle and cool conifer forest in upper mountain belt (Fig. 3). The highest percentages of arboreal pollen together with high scores of temperate forest characterize the middle Holocene as the most humid and warm period of the last $18 \mathrm{kyr}$.

A distinct change in the pollen spectra (Fig. 6) at the border between Unit III and Unit II (Fig. 5A), in the core 22-GC3, is known from the other Black Sea pollen records (Filipova et al., 1983; Atanassova and Bozilova, 1992; Shopov et al., 1992; Atanassova, 2005; FilipovaMarinova, 2006a, 2006b; Mudie et al., 2002a, 2007). These simultaneous changes in the core lithology and pollen record are accompanied by a major change in dinocyst assemblages, reflecting a shift from fresh/brackish (lacustrine) to salt-water (marine) environments (Fig. 7F, 
$7 \mathrm{G})$. The increase in salinity and the onset of sapropel formation in the Black Sea at $\sim 8.3 \mathrm{kyr}$ BP (Unit III/II) are explained by the opening of the Mediterranean corridor (e.g. Lamy et al., 2006; Marret et al., 2009; Verleye et al., 2009). The sharp change in pollen assemblages, including a distinct increase in pollen concentration, could be explained possibly by (i) a hiatus in sedimentation, (ii) better pollen preservation in anoxic environments and higher pollen concentrations under lower sedimentation rates, or/and (iii) the onset of wetter / warmer climatic conditions causing increase in vegetation cover density and possibly in pollen production.

The occurrence of a sedimentary hiatus is unlikely, since the magnetic susceptibility (Fig. 4), $\mathrm{Ca}$ and Ti values (Fig. 7D, 7E) in the core 22-GC3 analysed at higher resolution demonstrate rather gradual changes, suggesting a continuous sedimentation process. Pollen preservation indeed plays a very important role in regional palynological studies (e.g. Bottema et al., 1995), so that development of anoxia could be a good explanation for the better preservation of some pollen types with a thin and easily corroded exine layer (e.g. Juniperus, Taxus). However, the increase in the percentages of most other pollen with relatively thick stable exine (e.g. Fagus, Alnus, Carpinus betulus, Tilia etc.) requires a different explanation. Considering climatic changes, the onset of wet and warm conditions is revealed by terrestrial records from the Black Sea region. The mid-Holocene warm and moist climate was reconstructed using the pollen record from Yenicağa Lake in northern Anatolia (Bottema et al., 1995) and Lake Van in central Anatolia (Wick et al., 2003; Litt et al., 2009), where a noticeable increase in arboreal pollen percentages and change in taxa composition occurred at $\sim 8 \mathrm{kyr}$ BP. Pollen-based environmental reconstructions from Georgia (Connor and Kvavadze, 2008) also reveal the "climatic optimum" conditions about 7-4 kyr BP. Since moisture in northern Anatolia originates mainly from the Black Sea (Badertscher et al., 2011), high evaporation rates from the Black Sea surface and dominance of north-western winds are suggested to play a crucial role for Northern Anatolian precipitation regimes and, through these, also for vegetation. We consider changes in the regional climate accompanied by changes in the sedimentation rates as the most plausible reason for observed changes in the pollen diagram. While the resolution of the pollen record from 22-GC3 is about $300-320 \mathrm{yr}$ during the transition period, "rapid" change in pollen spectra actually covers several generations of trees.

In contrast to marine and terrestrial pollen records, $\delta^{13} \mathrm{C}$ from the Sofular Cave (Fig. $7 \mathrm{~K})$ do not show any significant changes at $\sim 8.3 \mathrm{kyr} \mathrm{BP}$. The $\delta^{13} \mathrm{C}$ record reacts very sensitively to climatic change during the late-glacial interval, when change in $\mathrm{C} 4 / \mathrm{C} 3$ plants 
was prominent. We assume that after the establishment of forest (C3-plant dominated) communities in northern Anatolia in the early Holocene, the $\delta^{13} \mathrm{C}$ record is possibly not able to reflect a further increase in available moisture.

\subsection{Late Holocene ( 5 kyr BP-present)}

The late Holocene interval is represented by LPZ 22GC3-2 and LPZ 22GC3-1 (Fig. 6, Table 5). Pollen spectra of LPZ 22GC3-2 (31-13 cm, 5-1.6 kyr BP) show a decrease in arboreal taxa (72-84\%). Pinus diploxylon-type, Quercus robur-type, Corylus and Alnus remain dominant taxa, but Fagus and Carpinus betulus pollen become less abundant and Abies and Taxus almost disappear. Herbaceous taxa, mainly Artemisia (7-12\%) and Chenopodiaceae (2-4\%), but also Poaceae, Apiaceae and Plantago lanceolata-type, show higher values. Scores of temperate deciduous/warm mixed forest remain high but are lower than in the previous zone (Fig. 6), and steppe scores increase to $\sim 6-9$, indicating some opening of the landscape. These trends continue in LPZ 22GC3-1 (13-0 cm, 1.6-0 kyr BP), which in addition demonstrates a decrease in Corylus percentages (2-5\%) and the more common occurrence of taxa, known as anthropogenic indicators, i.e. Juglans, Phillyrea, Ericaceae, Platanus orientalis, Plantago lanceolata-type and Rumex.

The decrease in arboreal pollen percentages and the increase in Artemisia, Chenopodiaceae and Poaceae after $\sim 5$ kyr BP indicate changes in the environment, which can be caused by climatic change, human impact, or by the combined effect of these factors. As mentioned (see 4.1.), it is difficult to separate anthropogenic and natural factors in the regional pollen diagrams, particularly in marine records. Climatic and anthropogenic reasons for a change in pollen spectra at around $\sim 4-6 \mathrm{kyr}$ BP have been discussed by different authors (e.g. Behre, 1990; Bottema and Woldring, 1990; Roberts et al., 2011). A more robust interpretation can be obtained by involving the other proxies, which cannot be directly influenced by human activities (e.g. isotope records of precipitation) and climate/vegetation modelling results (e.g. Tarasov et al., 2006; Kleinen et al., 2011). The rainfall reconstruction during the last $7 \mathrm{kyr}$, derived from speleothems of the Soreq Cave in Israel, demonstrates an abrupt shift in precipitation from 500-600 mm/yr to 400-500 mm/yr after $4.5 \mathrm{kyr}$ BP (BarMatthews and Ayalon, 2004), indicating the onset of drier conditions in the late Holocene. While a simple palaeo-rainfall indicator value of the oxygen isotope ratios in the speleothems from the eastern Mediterranean are under discussion (Frumkin et al., 1999; Kolodny et al., 2005), climate-based modelling of the changes in Eurasian forest cover over the past 8,000 years (Kleinen et al., 2011) is in agreement with this reconstruction in the south-eastern part 
of the Mediterranean region, but shows the Holocene trend towards a cooler climate in the Black Sea region accompanied by an increase in precipitation and in woody cover. This cooling trend is possible to trace in the 22-GC3 pollen record and in the pollen-based biome reconstruction. Particularly, an increase in non-dominant taiga (TAIG) biome scores in the upper part of the record (Fig. 6) likely indicates a strengthening of quasi-boreal elements in vegetation communities at higher elevations, in response to a relative cooling. The opening of the landscape suggested by the 22-GC3 pollen record thus might indicate deforestation due to human activities. Carpinus betulus and $C$. orientalis are typical pioneer trees, developing after the cutting of Fagus forests (Mayer and Aksoy, 1986), so that the increase in Carpinus betulus and Ostrya-type pollen could speak for deforestation. Pollen of Plantago lanceolatatype and Apiaceae, which appears more frequently after $3.5 \mathrm{kyr}$ BP, could be interpreted as being due to increased pasture area (e.g. Bottema and Woldring, 1990). The more frequent appearance of a few typical indicators of the "Beyşehir Occupation Phase" (Juglans, Platanus, Rumex) started in our record only at $\sim 1.5 \mathrm{kyr}$ BP, whereas other characteristic types of this phase do not show any significant changes (Olea, Fraxinus ornus, Cerealia-type, Vitis, Sanguisorba minor-type), or even decrease (Castanea, Juniperus) in comparison to previous periods. The latter finding corresponds well with Bottema et al. (1986), underlining the fact that indicators of the "Beyşehir Occupation Phase" are very typical of south-western Turkey and have not been found in diagrams from northern and eastern Turkey. Terrestrial pollen records from western (e.g. Tonkov et al., 2011), southern (e.g. Beug, 1967a; Bottema et al., 1995; Roberts et al., 2001; Vermoere et al., 2002; Wick et al., 2003; Litt et al., 2009) and eastern (e.g. Connor et al., 2007) regions reveal anthropogenic impact starting at $\sim 4$ kyr BP.

\section{Conclusions}

Vegetation and environmental dynamics in northern Anatolia during the last $18 \mathrm{kyr}$ are reconstructed using multi-proxy records from the upper $305 \mathrm{~cm}$ section of the Black Sea core 22-GC3. In general, signals from terrestrial northern Anatolian and Black Sea systems reflect well northern hemispheric climatic evidence. This suggests a cold and dry late Pleniglacial, melt-water pulses, warming / humidity increase during the late-glacial Interstadial, cool and dry late-glacial Stadial, increase in temperatures and humidity at the beginning of Holocene, and the most moist and warm conditions during the mid-Holocene. However, different records reveal their different sensitivity to climatic changes.

Increase in humidity during the melt-water pulses, indicated by $\delta^{18} \mathrm{O}$ records from 22 GC3 and the Sofular Cave ( 16.1-14.5 kyr BP), is better reflected in more negative $\delta^{13} \mathrm{C}$ 
values of speleothems from the Sofular Cave, and interpreted as spread of C3 plants. In contrast, the pollen response in 22-GC3 is very weak.

GI 1e ( 14.7-14.2 kyr BP) is indicated by an increase in dinocyst concentrations, reflecting higher primary productivity in the Black Sea, as well as in higher pine pollen percentages and more negative $\delta^{13} \mathrm{C}$ values in the Sofular Cave. A switch from primary allogenic to primary authigenic Ca occurs first at $\sim 14$ kyr BP. This event together with spread of oaks and higher concentrations of dinocysts strongly suggest further increases in temperature during GI 1a-c ( 14-12.9 kyr BP).

Onset of the late-glacial stadial is clearly reflected by terrestrial (decrease in arboreal pollen in 22-GC3, more positive $\delta^{13} \mathrm{C}$ values in the Sofular Cave) and marine (decrease in primary productivity, indicated by decrease in $\mathrm{Ca}$ and in dinocysts concentrations) records. Thereby, reconstructions from 22-GC3 suggest milder conditions during the late-glacial stadial in comparison to the late Pleniglacial. A pronounced decrease in pine percentages during the late-glacial stadial, also known from Eastern Mediterranean, is explained by upslope migration of pines with establishment of oaks in the middle mountain belt during the GI 1a-c and pine population damage during the late-glacial stadial.

Warming / humidity increase at the beginning of Holocene is clearly and synchronously indicated by terrestrial and marine signals. Thereby early Holocene vegetation in northern Anatolia presented mainly by oaks and pines likely reflects relatively dry environments.

Spreading of euxinian vegetation in northern Anatolia started after $\sim 8.3 \mathrm{kyr}$ BP and is correlated to the establishment of more saline conditions in the Black Sea after an inflow of Mediterranean water into the basin, indicated by changes in dinoflagellate cyst assemblages. Changes in the regional climate are suggested to play a crucial role in mid-Holocene vegetation changes.

The late Holocene vegetation changes in northern Anatolia were possibly caused by climate cooling, indicated by increase in TAIG biomes, and increased anthropogenic activities, indicated by a reduction in forest cover as well as by higher percentages of Ostreatype, Juglans, Platanus.

\section{Acknowledgments}

This paper is a contribution to the German Research Foundation (DFG) sponsored projects (BE 2116/20-1, TA-540/1-2; AR 367/9-1, FL 710/1-1) within the Priority Program 1266 "Integrated analysis of interglacial climate dynamics" (INTERDYNAMIC). We would like to thank Hans-Jürgen Beug, Galina Pashkevich and Eliso Kvavadze for providing us with 
necessary information, Erwin Bergmeier for consultation on vegetation in northern Turkey, Gilles Shephard and Laura Sutcliffe for polishing English. Special thanks go to the editor of "Palaeogeography, Palaeoclimatology, Palaeoecology" Prof. A. Peter Kershaw and anonymous reviewers for critical reading and improving the manuscript. Finally, we thank the captain and crew of RV Meteor for their support and contribution to the overall success of the M72/5 Black Sea research cruise in 2007.

\section{References}

Alpat'ev, A.M., Arkhangel'skii, A.M., Podoplelov, N.Y., Stepanov, A.Y., 1976. Fizicheskaya geografiya SSSR (Evropeiskaya chast'). Vysshaya Shkola, Moscow (in Russian).

Arslanov, Kh.A., Dolukhanov, P.M., Gei, N.A., 2007. Climate, Black Sea levels and human settlements in Caucasus Littoral 50,000-9000 BP. Quaternary International 167-168, 121-127.

Atanassova, 2005. Palaeoecological setting of the western Black Sea during the last 15000 years. The Holocene 15, 576-584.

Atanassova, J.R., Božilova, E.D., 1992. Palynological investication of marine sediments from the western sector of the Black Sea. Oceanology 1, 97-103.

Badertscher, S., Fleitmann, D., Cheng, H., Edwards, R.L., Göktürk, O.M., Zumbühl, A., Leuenberger, M., Tüysüz, O., 2011. Pleistocene water intrusions from the Mediterranean and Caspian Seas into the Black Sea. Nature Geoscience, DOI: 10.1038/NGEO1106.

Bahr, A., Arz, H.W., Lamy, F. Wefer, G., 2006. Late glacial to Holocene paleoenvironmental evolution of the Black Sea, reconstructed with stable oxygen isotope records obtained on ostracod shells. Earth and Planetary Science Letters 241, 863-875.

Bahr, A., Lamy, F., Arz, H., Kuhlmann, H., Wefer, G., 2005. Late glacial to Holocene climate and sedimentation history in the NW Black Sea. Marine Geology 214, 309-322.

Bahr, A., Lamy, F., Arz, H., Major, C., Kwiecien, O., Wefer, G., 2008. Abrupt changes of temperature and water chemistry in the late Pleistocene and early Holocene Black Sea. Geochemistry, Geophysics, Geosystems 9, doi:10.1029/2007GC001683.

Bard, E., Rostek, F., Turon, J.-L., Gendreau, S., 2000. Hydrological impact of Heinrich events in the subtropical Northeast Atlantic. Science 289, 1321-1324.

Bar-Matthews, M. and Ayalon A., 2004. Speleothems as paleoclimate indicators, a case study from Soreq cave located in the Eastern Mediterranean region, Israel. In Battarbee, R.W., 
Gasse, F., Stickley, C.E (Eds) Past Climate Variability through Europe and Africa, Kluwer Academic Publishers Dordrecht, The Netherlands, pp. 363-391.

Bartov, Y., Goldstein, S.L., Stein, M., Enzel, Y., 2003. Catastrophic arid episodes in the Eastern Mediterranean linked with the North Atlantic Heinrich events. Geology 31, 439-442.

Behre, K.-E., 1990. Some reflections on anthropogenic indicators and the record of prehistoric occupation phases in pollen diagrams from the Near East, in: Bottema, S., EntjesNieborg, G., Zeist, W. (Eds.), Man's Role in the Shaping of the Eastern Mediterranean Landscape. Balkema, Rotterdam, pp. 219-230.

Beug, H.-J., 1967a. Contributions to the postglacial vegetational history of Northern Turkey. Quaternary Paleoecology 7, 349-356.

Beug, H.-J., 1967b. Probleme der Vegetationsgeschichte in Südeuropa. Berichte der Deutschen Botanischen Gesellschaft 80, 682-689 (in German).

Beug, H.-J., 1977. Waldgrenzen und Waldbestand in Europa während des Eiszeitalters: Rede anläßlich der Übernahme des Rektorats der Universität am 16. April 1977. Göttinger Universitätsreden 61, 5-23 (in German).

Beug, H.-J., 2004. Leitfaden der Pollenbestimmung für Mitteleuropa und angrenzende Gebiete. Pfeil, München (in German).

Bezrukova, E.V., Tarasov, P.E., Solovieva, N., Krivonogov, S.K., Riedel, F., 2010. Last glacial-interglacial vegetation and environmental dymanics in southern Siberia: Chronology, forcing and feedbacks. Palaeogeography, Palaeoclimatology, Palaeoecology 296, 185-198.

Bottema, S., 1995. The Younger Dryas in the Eastern Mediterranean. Quaternary Science Reviews 14, 883-891.

Bottema, S., Woldring, H., 1984. Late Quaternary vegetation and climate of southwestern Turkey. Part II. Palaeohistoria 26, 123-149.

Bottema, S., Woldring, H., 1990. Anthropogenic indicators in the pollen record of the Eastern Mediterranean, in: Bottema, S., Entjes-Nieborg, G., Zeist, W. (Eds.) Man's Role in the Shaping of the Eastern Mediterranean Landscape. Balkema, Rotterdam, pp. 231-264.

Bottema, S., Woldring, H., Aytuğ, B., 1986. Palynological investigations on the Relation Between Prehistoric Man and Vegetation in Turkey: The Beyşehir Occupation Phase. 5th OPTIMA Meeting, Istanbul, 8-15 September 1986.

Bottema, S., Woldring, H., Aytuğ, B., 1995. Late Quaternary vegetation of Northern Turkey. Palaeohistoria 35/36, 13-72. 
Brewer, S., Cheddadi, R., Beaulieu, J.L., Reille, M., 2002. The spread of deciduous Quercus throughout Europe since the late glacial period. Forest Ecology and Management 156, 27-48.

Cacho, I., Grimalt, J.O., Sierro, F.J., Shackleton, N., Canals, M., 2000. Evidence of enhanced Mediterranean thermohaline circulation during rapid climatic cooling. Earth and Planetary Science Letters 183, 417-429.

Chapman, M.R., Maslin, M.A., 1999. Low-latitude forcing of meridional temperature and salinity gradients in the subpolar North Atlantic and the growth of glacial ice sheets. Geology 27, 875-878.

Chester, P.I., Raine, J.I., 2001. Pollen and spore keys for Quaternary deposits in the northern Pindos Mountains, Greece. Grana 40, 299-387.

Chmura, G.L., Santos, A., Pospelova, V., Spasojevic, Z., Lam, R., Latimer, J.S., 2004. Response of three paleo-primary production proxy measures to development of an urban estuary. Science of the Total Environment 320, 225-243.

Connor, S.E., Kvavadze, E.V., 2008. Modelling late Quaternary changes in plant distribution, vegetation and climate using pollen data from Georgia, Caucasus. Journal of Biogeography 36, 529-545.

Connor, S.E., Thomas, I., Kvavadze, E.V., 2007. A 5600-yr history of changing vegetation, sea levels and human impacts from the Black Sea coast of Georgia. The Holocene 17, 25-36.

Dale, B., 2001a. Marine dinoflagellate cysts as indicators of eutrophication and industrial pollution: a discussion. The Science of the Total Environments 264, 235-240.

Dale, B., 2001b. The sedimentary record of dinoflagellate cysts: looking back into the future of phytoplankton blooms. Scienta Marina 65, 257-272.

Dale, B., 2009. Eutrophication signals in the sedimentary record of dinoflagellate cysts in coastal waters. Journal of Sea Research 61, 103-113.

Dale, B., Thorsen, T.A., Fjellså, A., 1999. Dinoflagellate cysts as indicators of cultural eutrophication in the Oslofjord, Norway. Estuarine, Coastal and Shelf Science 48, 371382.

Davis, O.K., Shafer, D.S., 2006. Sporormiella fungal spores, a palynological means of detecting herbivore density. Palaeogeography, Palaeoclimatology, Palaeoecology 237, 40-50.

Demske, D., Heumann, G., Granoszewski, W., Nita, M., Mamakowa, K., Tarasov, P., Oberhänsli, H., 2005. Late glacial and Holocene vegetation and regional climate 
variability evidenced in high-resolution pollen records from Lake Baikal. Global and Planetary Change 46 (1-4), 255-279.

Desprat S., Sanchez-Goni M.F., Turon J.L., McManus J.F., Loutre M.F., Duprat J., Malaize B., Peyron O., Peypouquet J.P., 2005. Is vegetation responsible for glacial inception during periods of muted insolation changes? Quaternary Science Reviews 24, 13611374 .

Djamali, M., Akhani, H., Andrieu-Ponel, V., Braconnot, P., Brewer, S., de Beaulieu, J.-L., Fleitmann, D., Fleury, J., Gasse, F., Guibal, F., Jackson, S.T., Lézine, A.-M., Médail, F., Ponel, P., Roberts, N., Stevens, L., 2010. Indian Summer Monsoon varations could have affected the early-Holocene woodland expansion in the Near East. The Holocene 20, 813-820.

Dobrovolskiy, A.D., Zalogin, B.S., 1982. Moria SSSR. Moscow State University, Moscow (in Russian).

Eastwood, W.J., Leng, M.J., Roberts, N., Davis, B., 2007. Holocene climate change in the eastern Mediterranean region: a comparison of stable isotope and pollen data from Lake Gölhisar, southwest Turkey. Journal of Quaternary Science 22, 327-341.

Erdtman, G., 1960. The acetolysis method. Svensk Botanisk Tidskrift 54, 561-564.

Filipova-Marinova, M., 2006a. Palynostratigraphy of pleistocene and holocene sediments from the western Black Sea. JEMMM 3, 91-113.

Filipova-Marinova, M., 2006b. Late Pleistocene / Holocene dinoflagellate cyst assemblages from the Southwestern Black Sea shelf, in: Ognjanova-Rumenova, N., Manoylov, K. (Eds.), Advances in phycological studies. Pensoft Publishers \& University publishing house, Sofia-Moscow, pp.267-281.

Filipova, M.V., Božilova, E.D., Dimitrov, P.S., 1983. Palynological and stratigraphical data about the Quaternary from the Southern part of the Bulgarian Black Sea shelf. Oceanology 11, 24-32.

Fleitmann, D., Cheng, H., Badertscher, S., Edwards, R.L., Mudelsee, M., Göktürk, O.M., Fankhauser, A., Pickering, R., Raible, C.C., Matter, A., Kramers, J., Tüysüz, O., 2009. Timing and climatic impact of Greenland interstadials recorded in stalagmites from northern Turkey. Geophysical Research Letters 36, doi:10.1029/2009GL040050.

Frey, W., Kürschner, H., 1989. Vorderer Orient. Vegetation 1:8 000000 (Karte A VI I Tübinger Atlas des Vorderen Orients). Dr. Ludwig Reichert, Wiesbaden (in German).

Frumkin, A., Ford, D.C., Schwarcz, H.P., 1999. Continental oxygen isotopic record of the Last 170,000 years in Jerusalem. Quaternary Research 51, 317-327. 
Gerasimov, I.P. (Ed.), 1964. Atlas Mira. AN SSSR-GUGK SSSR, Moscow (in Russian).

Groot, J.J., Groot, C.R., 1966. Marine palynology: possibilities, limitations, problems. Marine Geology 4, 387-395.

Hay, B.J., Arthur, M.A., Dean, W.E., Neff, E.D., Honjo, S., 1991. Sediment deposition in the late Holocene abyssal Black Sea with climatic and chronological implifications. Deep Sea Research, Part A 38, suppl. 2, S1211-S1235.

Hooghiemstra, H., Lézine, A.-M., Leroy, S.A.G., Dupont, L., Marret, F., 2006. Late Quaternary palynology in marine sediments: A synthesis of the understanding of pollen distribution patterns in the NW African setting. Quaternary International 148, 29-44.

Hurrell, J.W., 1995. Decadal Trends in the North Atlantic Oscillation: Regional Temperatures and Precipitation. Science 269, 676-679.

Jansen, J.H.F., Van der Gaast, S.J., Koster, B., Vaars, A.J., 1998. CORTEX, a shipboard XRF-scanner for element anylysis in split sediment cores. Marine Geology 151, 143 153.

Jones, G.A., Gagnon, A.R., 1994. Radiocarbon chronology of the Black Sea sediments. DeepSea Research Part I 41, 531-557.

Jones, M.D., Roberts, C.N., Leng, M.J., 2007. Quantifying climatic change through the last glacial-interglacial transition based on lake isotope palaeohydrlogy from central Turkey. Quaternary Research 67, 463-473.

Juggins, S., 2003. C2 User Guide. Software for Ecological and Palaeoecological Data Analysis and Visualisation. University of Newcastle, Newcastle upon Tyne.

Kazmin, A.S., Zatsepin, A.G., 2007. Long-term variability of surface temperature in the Black Sea, and its connection with the largescale atmospheric forcing. Journal of Marine Systems 68, 293-301.

Kleinen, T., Tarasov, P., Brovkin, V., Andreev, A., Stebich, M., 2011. Comparison of modeled and reconstructed changes in forest cover through the past 8000 years: Eurasian perspective. The Holocene 21, 723-734.

Kolodny, Y., Stein, M., Machlus, M., 2005. Sea-rain-lake relation in the Last Glacial East Mediterranean revealed by $\delta^{18} \mathrm{O}-\delta^{13} \mathrm{C}$ in Lake Lisan aragonites. Geochimica et Cosmochimica Acta 69, 4045-4060.

Koreneva, E.V., Kartashova, G.G., 1978. Palynological study of samples from holes 379A, 380A, LEG 42B, in: Ross, D.A., Neprochnov, Y.P., Hsü, K.J., Stoffers, P., Supko, P., Trimonis, E.S., Percival, S.F., Erickson, A.J., Degens, E.T, Hunt, J.M., Manheim, F.T., 
Senalp, M., Traverse, A.(Eds.), Initial reports of the Deep Sea Drilling Project. U.S. Government Printing Office, Washington, pp. 951-992.

Kosarev, A.N., Kostianoy, A.G., 2008. Introduction. In: Kostianoy, G., Kosarev, A.N. (Eds.), The Handbook of Environmental Chemistry: Vol.5, Part Q: The Black Sea Environment. Springer Verlag, Berlin - Heidelberg, pp. 1-10. Kosarev, A.N., Arkhipkin, V.S., Surkova, G.V., 2008. Hydrometeorological Conditions, in: Kostianoy, G., Kosarev, A.N. (Eds.), The Handbook of Environmental Chemistry: Vol.5, Part Q: The Black Sea Environment. Springer Verlag, Berlin - Heidelberg, pp.135-158.

Kossler, A., 2010. Faunen und Floren der limnisch-telmatischen Schichtenfolge des Paddenluchs (Brandenburg, Rüdersdorf) vom ausgehenden Weichselhochglazial bis ins Holozän - Aussagen zu Paläomilieu und Klimabedingungen. Berliner paläobiologische Abhandlungen 11. Institut für Geologie Wissenschaften, Berlin (in German).

Kostianoy, G., Kosarev, A.N. 2008. The Handbook of Environmental Chemistry: Vol.5, Part Q: The Black Sea Environment. Springer Verlag, Berlin - Heidelberg.

Kotthoff, U., Müller, U.C., Pross, J., Schmiedl, G., Lawson, I.T., Schootbrugge, B. van de, Schulz, H., 2008. Lateglacial and Holocene vegetation dynamics in the Aegean region: an integrated view based on pollen data from marine and terrestrial archives. The Holocene 18, 1019-1032.

Kuhlemann, J., Rohling, E.J., Krumrei, I., Kubik, P., Ivy-Ochs, S., Kucera, M., 2008. Regional synthesis of Mediterranean atmospheric circulation during the last glacial maximum. Science 321, 1338-1340.

Kürschner, H., 1997. Pflanzen der Türkei: Ägäis - Taurus - Inneranatolien. Quelle \& Meyer Verlag, Wiesbaden (in German).

Kutzbach, J.E., Guetter, P.J., Behling, P.J., Selin, R., 1993. Simulated climatic changes: results of the COHMAP climate-model experiments. Chapter 4 In Global Climates since the Last Glacial Maximum (H.E. Wright, Jr, J.E.Kutzbach, T. Webb III, W.F. Ruddiman, F.A. Street-Perrott, and P.J. Bartlein, eds.), University of Minnesota Press, Minneapolis, MN, pp. 24-93.

Kvavadze, E.V., Rukhadze, L.P., 1989. Rastitel'nost' i klimat Golotsena Abkhazii. Metsniereba, Tbilisi (in Russian).

Kwiecien, O., Arz, H.W., Lamy, F., Plessen, B, Bahr, A., Haug, G.H., 2009. North Atlantic control on precipitation pattern in the eastern Mediterranean / Black Sea region during the last glacial. Quaternary Research 71, 375-384. 
Kwiecien, O., Arz, H.W., Lamy, F., Wulf, S., Bahr, A., Röhl, U., Haug, G.H., 2008. Estimated reservoir ages of the Black Sea since the last glacial. Radiocarbon 50, 99-118. Lamy, F., Arz, H.W., Bond, G.C., Bahr, A., Pätzold, J., 2006. Multicentennial-scale hydrological changes in the Black Sea and northern Red Sea during the Holocene and the Arctic/North Atlantic Oscillation. Paleoceanography 21, doi: 10.1029/2005PA001184.

Lehmkuhl, F., Friesa, S., Hülle, D., Hilgers, A., Shumilovskikh, L., Schlütz, F., Felauer, T., Protzea, J., 2011. Holocene geomorphological processes and soil development as indicator for environmental change around Karakorum, Upper Orkhon Valley (Central Mongolia). Catena 87, 31-44.

Leng, M.J., Marshall, J.D., 2004. Palaeoclimate interpretation of stable isotope data from lake sediment archives. Quaternary Science Reviews 23, 811-831.

Leroy, S., Arpe, K., 2007. Glacial refugia for summer-green trees in Europe and south-west Asia as proposed by ECHAM3 time-slice atmospheric model simulations. Journal of Biogeography 34, 2115-2128.

Litt, T., Krastel, S., Sturm, M., Kipfer, R., Örcen, S., Heumann, G., Franz, S.O., Ülgen, U.B., Niessen, F., 2009. ,PALEOVAN‘, International Continental Scientific Drilling Program (ICDP): site survey results and perspectives. Quaternary Science Reviews 28, 15551567.

Litt, T., Schmincke, H.-U., Kromer, B., 2003. Environmental response to climatic and volcanic events in central Europe during the Weichselian Lateglacial. Quaternary Science Reviews 22, 7-32.

Louis, H., 1939. Das natürliche Pflanzenkleid Anatoliens. J. Engelhorns Nachf. Adolf Spemann, Stuttgart (in German).

Marret, F., Zonneveld, K.A.F., 2003. Atlas of modern organic-walled dinoflagellate cyst distribution. Review of Palaeobotany and Palynology 125, 1-200.

Marret, F., Leroy, S., Chalié, F., Gasse, F., 2004. New organic-walled dinoflagellate cysts from recent sediments of Central Asian seas. Review of Palaeobotany and Palynology $129,1-20$.

Marret, F., Mudie, P., Aksu, A., Hiscott, R.N., 2009. A Holocene dinocyst record of a twostep transformation of the Neoeuxinian brackish water lake into the Black Sea. Quaternary International 197, 72-86. 
Matsuoka, K., 1999. Eutrophication process recorded in dinoflagellate cyst assemblages - a case of Yokohama Port, Tokyo Bay, Japan. Science of the Total Environment 231, 17 35.

Matsuoka, K., 2001. Further evidence for a marine dinoflagellate cyst as an indicator of eutrophication in Yokohama Port, Tokyo Bay, Japan. Comments on a discussion by B. Dale. Science of the Total Environment 264, 221-233.

Mayer, H., Aksoy, H., 1986. Wälder der Türkei. Gustav Fischer Verlag, Stuttgart-New York (in German).

Médail, F., Diadema, K., 2009. Glacial refugia influence plant diversity patterns in the Mediterranean Basin. Journal of Biogeography 36, 1333-1345.

Miehe, G., Miehe, S., Kaiser, K., Reudenbach, C., Behrendes, L., La Duo, Schlütz, F., 2009. How old is Pastoralism in Tibet? An Ecological Approach to the Making of a Tibetan Landscape. Palaeogeography, Palaeoclimatology, Palaeoecology 276, 130-147.

Moore, P.D., Webb, J.A., Collinson, M.E., 1999. Pollen analysis. Blackwell, Oxford.

Mudie, P.J., Aksu, A.E., Yasar, D., 2001. Late Quaternary dinoflagellate cysts from the Black, Marmara and Aegean seas: variations in assemblages, morphology and paleosalinity. Marine Micropaleontology 43, 155-178.

Mudie, P.J., Leroy, S.A.G., Marret, F., Gerasimenko, N.P., Kholeif, S.E.A., Sapelko, T., Filipova-Marinova, M., 2011. Nonpollen palynomorphs: Indicators of salinity and environmental change in the Caspian-Black Sea-Mediterranean corridor, in: Buynevich, I.V., Yanko-Hombach, V., Gilbert, A.S., Martin, R.E. (Eds.), Geology and Geoarchaeology of the Black Sea Region: beyond the Flood Hypothesis. The Geological Society of America, Boulder, pp. 89-115.

Mudie, P.J., Marret, F., Aksu, A.E., Hiscott, R.N., Gillespie, H., 2007. Palynological evidence for climatic change, anthropogenic activity and outflow of Black Sea water during the last Pleistocene and Holocene: Centennial- to decadal-scale records from the Black and Marmara Seas. Quaternary International 167-168, 73-90.

Mudie, P.J., Rochon, A., Aksu, A.A., 2002a. Pollen stratigraphy of Late Quaternary cores from Marmara Sea: land-sea correlation and paleoclimatic history. Marine Geology 190, 233-260.

Mudie, P.J., Rochon, A., Aksu, A.E., Gillespie, H., 2002b. Dinoflagellate cysts, freshwater algae and fungal spores as salinity indicators in Late Quaternary cores from Marmara and Black seas. Marine Geology 190, 203-231. 
Mudie, P.J., Rochon, A., Aksu, A.E., Gillespie, H., 2004. Late glacial, Holocene and modern dinoflagellate cyst assemblages in the Aegean - Marmara - Black Sea corridor: statistical analysis and re-interpretation of the early Holocene Noah's Flood hypothesis. Review of Palaeobotany and Palynlogy 128, 143-167. Müller, S., Tarasov, P.E., Andreev, A.A., Tütken, T., Gartz, S., Diekmann, B., 2010. Late Quaternary vegetation and environments in the Verkhoyansk Mountains region (NE Asia) reconstructed from a 50-kyr fossil pollen record from Lake Billyakh. Quaternary Science Reviews 29, 2071 2086.

Müller, U.C., Pross, J., Tzedakis, P.C., Gamble, C., Kotthoff, U., Schmiedl, G., Wulf, S., Christianis, K., 2011. The role of climate in the spread of modern humans into Europe. Quaternary Science Reviews 30, 273-279.

Oguz, T., Latun, V.S., Latif, M.A., Vladimirov, V.V., Sur, H.I., Markov, A.A., Özsoy, E., Kotovshchikov, B.B., Eremeev, V.V., Ünlüata, Ü., 1993. Circulation in the surface and intermediate layers of the Black Sea. Deep-Sea Research 40, 1597-1612.

Özsoy, E., Ünlüata, Ü., 1997. Oceanography of the Black Sea: a review of some recent results. Earth-Science Reviews 42, 231-272.

Peyron, O., Guiot, J., Cheddadi, R., Tarasov, P.E., Reille, M., Beaulieu, J.-L. de, Bottema, S., Andrieu, V., 1998. Climatic reconstruction in Europe from pollen data, 18,000 years before present. Quaternary Research 49, 183-196.

Prentice, I.C., Cramer, W., Harrison, S.P., Leemans, R., Monserud, R.A., Solomon, A.M., 1992. A global biome model based on plant physiology and dominance, soil properties, and climate. Journal of Biogeography 19, 117-134.

Prentice, I.C., Guiot, J., Huntley, B., Jolly, D., Cheddadi, R., 1996. Reconstructing biomes from palaecological data: a general method and its application to European pollen data at 0 and $6 \mathrm{ka}$. Climate Dynamics 12, 185-194.

Quézel, P., Barbéro, M., 1985. Carte de la vegetation potentielle de la région méditerranéenne. Feuille No. 1: Méditerranée orientale. C.N.R.S. Paris (in French).

Raper, D., Bush, M., 2009. A test of Sporormiella representation as a predictor of megaherbivore presence and abundance. Quaternary Research 71, 490-496.

Richter, T.O., Van der Gaast, S., Koster, B., Vaars, A., Gieles, R., de Stigter, H.C., de Haas, H., van Weering, T.C.E., 2006. The Avaatech XRF Core Scanner: Technical description and applications to NE Atlantic sediments, in: Rothwell, G. (Ed.), New Techniques in Sediment Core Analysis, 267. Geological Society Special Publications, London, pp. 3950. 
Roberts, N., 1983. Age, Palaeoenvironments, and Climatic Significance of Late Pleistocene Konya Lake, Turkey. Quaternary Research 19, 154-171.

Roberts, N., Wright, H.E., 1993. Vegetational, Lake-Level, and Climatic History of Near East and Southwest Asia, in: Wright, H.E., Kutzbach, J.E., Webb III, T., Ruddiman, W.F., Street-Perrott, F.A., Bartlein, P.J. (Eds.), Global Climates since the Last Glacial Maximum. University of Minnesota Press, Minneapolis, London, pp.194-220.

Roberts, N., Eastwood, W.I., Kuzucuoğlu, G.F., Caracuta, V., 2011. Climatic, vegetation and cultural change in the eastern Medirranean during the mid-Holocene environmental transition. The Holocene 21, 147-162.

Roberts, N., Reed, J.M., Leng, M.J., Kuzucuoğlu, C., Fontugne, M.,Bertaux, J., Woldring, H., Bottema, S., Black, S., Hunt, E., Karabıyıkoğlu, M., 2001. The tempo of Holocene climatic change in the eastern Mediterranean region: new high-resolution crater-lake sediment data from central Turkey. The Holocene 11, 721-736.

Rochon, A., Vernal, A. de, Turon, J.-L., Matthiessen, J., Head, M.J., 1999. Distribution of recent dinoflagellate cysts in surface sediments from the north Atlantic ocean and adjacent seas in relation to sea-surface parameters. AASP Contributions Series 35, 7-59.

Ross, D., Degens, E.T., 1974. Recent sediments of Black Sea, in: Degens, E.T., Ross, D., (Eds.), The Black Sea - Geology, Chemistry and Biology. American Association of Petroleum Geologists, Tulsa, Okla, pp. 183-199.

Röhl, U., Abrams, L.J., 2000. High-resolution, downhole and nondestructive core measurements from sites 999 and 1001 in the Caribbean Sea: application to the late Paleocene thermal maximum, in: Leckies, R.M., Sigurdsson, H., Acton, G.D., Draper, G. (Eds.), Proceedings of the Ocean Drilling Program Scientific Results 165, 191-203.

Sarikaya, M.A., Zreda, M., Çiner, A., Zweck, C., 2008. Cold and wet Last Glacial Maximum on Mount SandIras, SW Turkey, inferred from cosmogenic dating and glacier modeling. Quaternary Science Reviews 27, 769-780.

Schlütz, F., Lehmkuhl, F., 2009. Holocene climatic change and the nomadic Anthropocene in Eastern Tibet: Palynological and geomorphological results from the Nianbaoyeze Mountains. Quaternary Science Reviews 28, 1449-1471.

Schlütz, F., Dulamsuren, C., Wieckowska, M., Mühlenberg, M., Hauck, M., 2008. Late Holocene vegetation history suggests natural origin of steppes in the northern Mongolian mountain taiga. Palaeogeography, Palaeoclimatology, Palaeoecology 261, 203-217. 
Shatilova, I.I., 1974. Palinologicheskoe obosnovanie geokhronologii verhnego Pliotsena i Pleistotsena zapadnoy Gruzii. Metsniereba, Tbilisi (in Russian).

Shatilova, I., Mchedlishvili, N., Rukhadze, L., Kvavadze, E., 2011. The history of the flora and vegetation of Georgia (South Caucasus). Georgian national museum, Tbilisi.

Shopov, V.L., Božilova, E.D., Atanasova, J.R., 1992. Biostratigraphy and radiocarbon data of Upper Quaternary sediments from western part of Black Sea. Geologica Balcanica 22, 59-69.

Stebich, M., Mingram, J., Han, J., Liu, J., 2009. Late Pleistocene spread of (cool-)temperate forests in Northeast China and climate changes synchronous with the North Atlantic region. Global and Planetary Change 65, 56-70.

Stockmarr, J., 1971. Tablets with Spores used in Absolute Pollen Analysis. Pollen et Spores $13,615-621$.

Svensson, A., Andersen, K.K., Bigler, M., Clausen, H.B., Dahl-Jensen, D., Davies, S.M., Johnsen, S.J., Muscheler, R., Parrenin, F., Rasmussen, S.O., Rothlisberger, R., Seierstad, I., Steffensen, J.P., Vinther, B.M., 2008. A 60000 year Greenland stratigraphic ice core chronology. Climate of the Past 4, 47-57.

Tarasov, P.E., Bezrukova, E.V., Krivonogov, S.K., 2009. Late glacial and Holocene changes in vegetation cover and climate in southern Siberia derived from a $15 \mathrm{kyr}$ long pollen record from Lake Kotokel. Climate of the Past 5, 73-84.

Tarasov, P.E., Cheddadi, R., Guiot, J., Bottema, S., Peyron, O., Belmonte, J., Ruiz-Sanchez, V., Saadi, F. A., Brewer, S., 1998a. A method to determine warm and cool steppe biomes from pollen data; application to the Mediterranean and Kazakhstan Regions. Journal of Quaternary Science 13/4, 335-344.

Tarasov, P., Jin, G., Wagner, M., 2006. Mid-Holocene environmental and human dynamics in northeastern China reconstructed from pollen and archaeological data. Palaeogeography, Palaeoclimatology, Palaeoecology 241, 284-300.

Tarasov, P.E., Peyron, O., Guiot, J., Brewer, S., Volkova, V.S., Bezusko, L.G., Dorofeyuk, N.I., Kvavadze, E.V., Osipova, I.M., Panova, N.K., 1999. Last Glacial Maximum climate of the Former Soviet Union and Mongolia reconstructed from pollen and plant macrofossil data. Climate Dynamics 15, 227-240.

Tarasov, P.E., Volkova, V.S., Webb III, T., Guiot, J., Andreev, A.A., Bezusko, L.G., Bezusko, T.V., Bykova, G.V., Dorofeyuk, N.I., Kvavadze, E.V., Osipova, I.M., Panova, N.K., Sevastyanov, D.V., 2000. Last Glacial Maximum biomes reconstructed from 
pollen and plant macrofossil data from northern Eurasia. Journal of Biogeography 27, 609-620.

Tarasov, P.E., Webb III, T., Andreev, A.A., Afanas'eva, N.B., Berezina, N.A., Bezusko, L.G., Blyakharchuk, T.A., Bolikhovskaya, N.S., Cheddadi, R., Chernavskaya, M.M., Chernova, G.M., Dorofeyuk, N.I., Dirksen, V.G., Elina, G.A., Filimonova, L.V., Glebov, F.Z., Guiot, J., Gunova, V.S., Harrison, S.P., Jolly, D., Khomutova, V.I., Kvavadze, E.V., Osipova, I. M., Panova, N.K., Prentice, I.C., Saarse, L., Sevastyanov, D.V., Volkova, V.S., Zernitskaya, V.P., 1998b. Present-day and mid-Holocene Biomes Reconstructed from Pollen and Plant Macrofossil Data from the Former Soviet Union and Mongolia. Journal of Biogeography 25, 1029-1053.

Tonkov, S., Beug, H.-J., Božilova, E., Filipova-Marinova, M., Jungner, H., 2011. Palaeoecological studies at the Kaliakra area, northeastern Bulgarian Black Sea coast: 6000 years of natural and anthropogenic change. Vegetation History and Archaeobotany $20,29-40$.

Traverse, A., 1974. Palynological investigation of two Black Sea cores, in: Degens, E.T., Ross, D.A. (Eds.) The Black Sea: geology, chemistry and biology. American Association of Petroleum Geologists, Tulsa, Oklahoma, pp. 381-388.

Traverse, A., 1978. Palynological analysis of DSDP LEG 42B (1975) cores from the Black Sea, in: Ross, D.A., Neprochnov, Y.P., Hsü, K.J., Stoffers, P., Supko, P., Trimonis, E.S., Percival, S.F., Erickson, A.J., Degens, E.T, Hunt, J.M., Manheim, F.T., Senalp, M., Traverse, A. (Eds.), Initial reports of the Deep Sea Drilling Project. U.S. Government Printing Office, Washington, pp. 993-1015.

Türkeş, M., Sümer, U.M., Kiliç, G., 1996. Observed changes in maximum and minimum temperatures in Turkey. International Journal of Climatology 16, 463-477.

Türkeş, M., Erlat, E., 2003. Precipitation changes and variability in Turkey linked to the North Atlantic Oscillation during the period 1930-2000. International Journal of Climatology 23, 1771-1796.

Türkeş, M., Koç, T., Sariş, F., 2009. Spatiotemporal variability of precipitation total series over Turkey. International Journal of Climatology 29, 1056-1074.

Van Geel, B., Buurman, J., Brinkkemper, O., Schelvis, J, Aptroot, A., Reenen, G. van, Hakbijl, T., 2003. Environmental reconstructions of a Roman Period settlement site in Uitgeest (the Netherlands), with special reference to coprophilous fungi. Journal of Archaeological Science 30, 873-884. 
Van Geel, B., Coope, G., Hammen, T. van der, 1989. Palaeoecology and stratigraphy of the Late Glacial type section at Usselo (the Netherlands). Review of Palaeobotany and Palynology 60, 25-129.

Verleye, T.J., Mertens, K.N., Louwye, S., Arz, H.W., 2009. Holocene salinity changes in the southwestern Black Sea: a reconstruction based on dinoflagellate cysts. Palynology 33, 77-100.

Vermoere, M., Bottema, S., Vanhecke, L., Waelkens, M., Paulissen, E. Smets, E., 2002. Palynological evidence for late-Holocene human occupation recorded in two wetlands in SW Turkey. The Holocene 12, 569-584.

Wall, D., Dale, B., Harada, K., 1973. Descriptions of new fossil dinoflagellates from the Late Quaternary of the Black Sea. Micropaleontology 19, 18-31.

Wick, L., Lemcke, G., Sturm, M., 2003. Evidence of Lateglacial and Holocene climatic change and human impact in eastern Anatolia: high-resolution pollen, charcoal, isotopic and geochemical records from the laminated sediments of Lake Van, Turkey. The Holocene 13, 665-675.

Zeist, W. van, Woldring, H., Stapert, D., 1975. Late Quaternary vegetation and climate of southwestern Turkey. Palaeohistoria 17, 55-143.

Zhang, Y., Crous, P.W., Schoch, C.L., Hyde, K.D., 2011. Pleosporales. Fungal Diversity, DOI 10.1007/s13225-011-0117-x.

Zohary, M., 1973. Geobotanical foundations of the Middle East. Fischer, Stuttgart, Amsterdam. 
Table A1. Terrestrial pollen taxa identified in the 22-GC3 core record and used in the biome reconstructions.

\begin{tabular}{|c|c|}
\hline $\begin{array}{l}\text { Biome full/abbreviated } \\
\text { name (after Prentice et } \\
\text { al., 1996) }\end{array}$ & Plant/pollen taxa included (after Peyron et al., 1998; Tarasov et al., 1998b, 2000) \\
\hline $\begin{array}{l}\text { Arctic/alpine } \\
\text { tundra/TUND }\end{array}$ & $\begin{array}{l}\text { Alnus, Betula, Cyperaceae, Ericales, Gentianaceae, Poaceae, Polygonum, Rumex, } \\
\text { Salix, Saussurea, Saxifragaceae, Scrophulariaceae, Valeriana }\end{array}$ \\
\hline $\begin{array}{l}\text { Cold deciduous } \\
\text { forest/CLDE }\end{array}$ & $\begin{array}{l}\text { Alnus, Betula, Ericales, Juniperus, Pinaceae, Pinus subgen. Diploxylon-type, Pinus } \\
\text { subgen. Haploxylon-type, Salix }\end{array}$ \\
\hline Taiga/TAIG & $\begin{array}{l}\text { Abies, Alnus, Betula, Cornus, Ericales, Juniperus, Picea, Pinaceae, Pinus subgen. } \\
\text { Diploxylon-type, Pinus subgen. Haploxylon-type, Salix, Sambucus, Sorbus, } \\
\text { Viburnum }\end{array}$ \\
\hline $\begin{array}{l}\text { Cold mixed } \\
\text { forest/CLMX }\end{array}$ & $\begin{array}{l}\text { Abies, Alnus, Betula, Carpinus, Cedrus, Cornus, Corylus, Ericales, Fagus, Frangula, } \\
\text { Juniperus, Pinaceae, Pinus subgen. Diploxylon-type, Prunus, Salix, Sambucus, } \\
\text { Sorbus, Taxus, Tilia, Ulmus, Viburnum }\end{array}$ \\
\hline $\begin{array}{l}\text { Cool conifer } \\
\text { forest/COCO }\end{array}$ & $\begin{array}{l}\text { Abies, Alnus, Betula, Carpinus, Cornus, Corylus, Ericales, Fagus, Frangula, } \\
\text { Juniperus, Picea, Pinaceae, Pinus subgen. Diploxylon-type, P. subgen. Haploxylon- } \\
\text { type, Prunus, Salix, Sambucus, Sorbus, Tilia, Ulmus, Viburnum }\end{array}$ \\
\hline $\begin{array}{l}\text { Cool mixed } \\
\text { forest/COMX }\end{array}$ & $\begin{array}{l}\text { Abies, Acer, Alnus, Betula, Carpinus, Cornus, Corylus, Ericales, Fagus, Frangula, } \\
\text { Fraxinus excelsior-type, Juniperus, Picea, Pinaceae, P. subgen. Diploxylon-type, P. } \\
\text { subgen. Haploxylon-type, Prunus, Quercus deciduous-type, Salix, Sambucus, } \\
\text { Sorbus, Tilia, Ulmus, Viburnum }\end{array}$ \\
\hline $\begin{array}{l}\text { Temperate deciduous } \\
\text { forest/TEDE }\end{array}$ & $\begin{array}{l}\text { Abies, Acer, Alnus, Betula, Buxus, Carpinus, Castanea, Cedrus, Cornus, Corylus, } \\
\text { Cotinus, Engelhardia, Ericales, Fagus, Frangula, Fraxinus angustifolia var. } \\
\text { oxycarpa-type, Fraxinus excelsior-type, Fraxinus ornus-type, Hedera, Ilex, } \\
\text { Juglandaceae, Juglans, Juniperus, Loranthus, Myrica, Ostrya, Pinaceae, P. subgen. } \\
\text { Diploxylon-type, Platanus, Prunus, Pterocarya, Quercus deciduous-type, Rhamnus, } \\
\text { Salix, Sambucus, Sorbus, Taxus, Tilia, Ulmus, Viburnum, Vitis }\end{array}$ \\
\hline $\begin{array}{l}\text { Broad-leaved } \\
\text { evergreen/warm mixed } \\
\text { forest/WAMX }\end{array}$ & $\begin{array}{l}\text { Acer, Alnus, Buxus, Carpinus, Carya, Castanea, Celtis, Cornus, Corylus, Cotinus, } \\
\text { Engelhardia, Ericales, Fagus, Frangula, Fraxinus angustifolia var. oxycarpa-type, } \\
\text { Fraxinus excelsior-type, Fraxinus ornus-type, Hedera, Ilex, Juglandaceae, Juglans, } \\
\text { Juniperus, Lauraceae, Loranthus, Myrica, Ostrya, Pinaceae, P. subgen. Diploxylon- } \\
\text { type, Platanus, Prunus, Pterocarya, Quercus deciduous-type, Quercus evergreen- } \\
\text { type, Rhamnus, Salix, Sambucus, Sorbus, Taxus, Tilia, Ulmus, Viburnum, Vitis }\end{array}$ \\
\hline $\begin{array}{l}\text { Xerophytic } \\
\text { woods/scrub/XERO }\end{array}$ & $\begin{array}{l}\text { Caragana, Celtis, Genista, Juniperus, Olea, Phillyrea, Pinaceae, Pinus subgen. } \\
\text { Diploxylon-type, Pistacia, Prunus, Quercus evergreen-type, Fumana, Genista, } \\
\text { Hedysarum, Poaceae, Thymelaeaceae }\end{array}$ \\
\hline Steppe/STEP & $\begin{array}{l}\text { Allium, Anagallis, Apiaceae, Artemisia, Asteraceae subfam. Asteroideae, Asteraceae } \\
\text { subfam. Cichorioideae, Ballota, Bistorta, Brassicaceae, Cannabaceae, Caragana, } \\
\text { Caryophyllaceae, Centaurea, Cerinthe, Chenopodiaceae, Circium, Convallaria, } \\
\text { Dipsacus, Fabaceae, Fagopyrum, Filipendula, Galeopsis, Genista, Geum, } \\
\text { Hedysarum, Helianthemum, Hippophae, Kickxia, Lamiaceae, Liliaceae, Litorella, } \\
\text { Lythrum, Matricaria, Mentha, Mercurialis, Molopospermum, Muscari, Narcissus, } \\
\text { Onosma, Papaveraceae, Plantaginaceae, Plantago, Plumbaginaceae, Poaceae, } \\
\text { Polygonaceae, Polygonum, Potentilla, Primula, Ranunculaceae, Rheum, Rhinanthus, } \\
\text { Rubiaceae, Rumex, Sanguisorba, Saussurea, Scabiosa, Scrophulariaceae, Senecio, } \\
\text { Spergula, Symphytum, Thalictrum, Thymelaeaceae, Tribulus, Valeriana, Verbena }\end{array}$ \\
\hline Desert/DESE & $\begin{array}{l}\text { Artemisia, Caragana, Chenopodiaceae, Ephedra distachia-type, Ephedra fragilis- } \\
\text { type, Haloxylon, Polygonum, Tamarix, Tribulus }\end{array}$ \\
\hline
\end{tabular}




\title{
MANUSCRIPT 2
}

\section{Eemian and Holocene sea-surface conditions in the southern Black Sea: organic- walled dinoflagellate cyst record from core 22-GC3}

\author{
Lyudmila S. Shumilovskikh ${ }^{1 *}$, Fabienne Marret ${ }^{2}$, Dominik Fleitmann $^{3,4}$, Helge W. Arz ${ }^{5}$, \\ Norbert Nowaczyk ${ }^{6}$, Hermann Behling ${ }^{1}$
}

1 Department of Palynology and Climate Dynamics, University of Göttingen, Untere Karspüle 2, 37073 Goettingen, Germany

2 School of Environmental Sciences, University of Liverpool, Liverpool, L69 7ZT, UK

3 Institute of Geological Sciences, Baltzerstrasse 3, 3012 Bern, Switzerland

4 Oeschger Centre for Climate Change Research, University of Bern, Zähringerstrasse 25, 3012 Bern, Switzerland

5 Leibniz Institute for Baltic Sea Research Warnemuende, Seestrasse 15, 18119 Rostock-

Warnemuende, Germany

6 GeoForschungsZentrum-Potsdam, Telegrafenberg, 14473 Potsdam, Germany

Published in:

Marine Micropaleontology, 101, 146-160 (2013)

(C) 2013 Elsevier B.V. All rights reserved.

doi: 10.1016/j.marmicro.2013.02.001 


\begin{abstract}
In order to compare the sea-surface conditions in the Black Sea during the Holocene and Eemian, sapropelic parts of marine core $22-\mathrm{GC} 3\left(42^{\circ} 13.53{ }^{\prime} \mathrm{N} / 36^{\circ} 29.55^{\prime} \mathrm{E}, 838 \mathrm{~m}\right.$ water depth) were studied for organic-walled dinoflagellate cyst content. The record shows a change from fresh/brackish assemblages (Pyxidinopsis psilata, Spiniferites cruciformis, Caspidinium rugosum) to more marine assemblages (Lingulodinium machaerophorum, Spiniferites ramosus complex) during each interglacial, due to the inflow of saline Mediterranean water. The lacustrine - marine transitions in 22-GC3 occurred at $\sim 8.3 \mathrm{kyr}$ BP (if not stated otherwise, all ages are given in cal kyr BP) during the early Holocene and 128 kyr BP during the early Eemian, slightly later compared to the onset of interglacial conditions on the adjacent land. Dinoflagellate cyst assemblages reveal higher sea-surface salinity ( 28-30) (e.g. Spiniferites pachydermus, Bitectatodinium tepikiense, Spiniferites mirabilis) around 126.5-121 kyr BP in comparison to the Holocene $(\sim 15-20)$ as well as relatively high seasurface temperature (e.g. Tuberculodinium vancampoae, Spiniferites pachydermus, Spiniferites mirabilis) especially at $\sim 127.6-125.3 \mathrm{kyr}$ BP. Establishment of high sea-surface salinity during the Eemian correlates very well with reconstructed relatively high global sealevel and is explained as a combined effect of increased Mediterranean supply and high temperatures at the beginning of the last interglacial. Changes in dinocyst record highlight the importance of nutrients for the composition of the Eemian and Holocene dinocyst assemblages.
\end{abstract}

Key words: Mediterranean - Black Sea reconnection; sea-surface temperature; seasurface salinity; nutrients; sea-level change; last interglacial 


\section{Introduction}

The Black Sea is a semi-closed basin that is connected to the Marmara and Mediterranean Seas through the rather shallow Bosphorus sill (37 m below present sea level $(=\mathrm{bpsl}))$ and the deeper Dardanelles sill $(87 \mathrm{~m} \mathrm{bpsl})$. Mediterranean water inflow causes a sea-surface salinity of 17-18 in the modern Black Sea. During glacial periods when global or Mediterranean sea level was below the depth of the Bosphorus sill, the Black Sea was cut off from the Mediterranean Sea and turned into a giant freshwater/brackish lake (e.g. Ross et al., 1978; Svitoch, 2008; Badertscher et al., 2011). In contrast, during interglacial periods and high global sea levels, saline Mediterranean water spilled into the Black Sea and salinity substantially increased. Several of these drastic hydrological changes from a freshwater/brackish into a brackish/marine state are documented in sedimentary sequences and speleothems (e.g. Ross et al., 1978; Svitoch, 2008; Badertscher et al., 2011). In particular, the last intrusion of Mediterranean water into the Black Sea at around 9.3 kyr BP (Bahr et al., 2008) has been intensively studied in order to confirm or disprove the "Noah's flood hypothesis" proposed by Ryan and Pittman (1998). As a result, numerous biological, sedimentological and geochemical sediment records provide detailed information on the hydrological state of the Black Sea for the last 25 kyr (e.g. Bahr et al., 2005, 2006; YankoHombach et al., 2007; Bahr et al., 2008; Kwiecien et al., 2008, 2009; Buynevich et al., 2011). For this time interval, the lithostratigraphy of the late glacial and Holocene sediments of the Black Sea consists of three lithological units (Ross and Degens, 1974; Hay et al., 1991; Lamy et al., 2006). The lower Unit III is composed of lacustrine clays with occasional laminations, deposited in the fresh- or brackish-water environments during the late glacial and the onset of the Holocene. Unit II consists of finely laminated sapropel sediments (e.g. Ross and Degens, 1974; Lamy et al., 2006), whose formation started at around $8.3 \mathrm{kyr}$ BP due to an increase in salinity and anoxia formation. The youngest Unit I consisting of a finely laminated coccolith ooze layer started to build at around $2.7 \mathrm{kyr}$ BP (Lamy et al., 2006), when the coccolithophorid Emiliania huxleyi was spreading in the Black Sea. This sedimentary sequence reveals that the main changes in the Black Sea environment and sedimentation during the Holocene were caused by a marked salinity increase as a result of the inflow of Mediterranean water.

The pioneering studies of Wall et al. (1973) and Wall and Dale (1974) on organicwalled dinoflagellate cysts (=dinocysts) provided the first biostratigraphic distribution and palaeoecological relationships of dinocysts for the late Pleniglacial and the Holocene in the Black Sea. A number of sediment cores mainly from the southern part of the Black Sea basin 
(Fig. 1) have highlighted the strong potential of dinocysts to estimate past sea-surface conditions (Wall et al., 1973; Wall and Dale, 1974; Mudie et al., 2001, 2002, 2004; Atanassova, 2005; Filipova-Marinova, 2006; Mudie et al., 2007; Marret et al., 2009; Verleye et al., 2009; Mertens et al., 2012). Salinity increase during the Unit III/Unit II transition at around 8.3 kyr BP eliminated fresh/brackish Spiniferites cruciformis / Pyxidinopsis psilata assemblages, whilst Lingulodinium machaerophorum accompanied by Spiniferites species became dominant. During the late Holocene, the peridinoid species Peridinium ponticum dominated the dinocyst assemblages. Overall, the late glacial and Holocene changes in the hydrology of the Black Sea known from sedimentary sequence, are clearly reflected by changes in dinocyst assemblages.

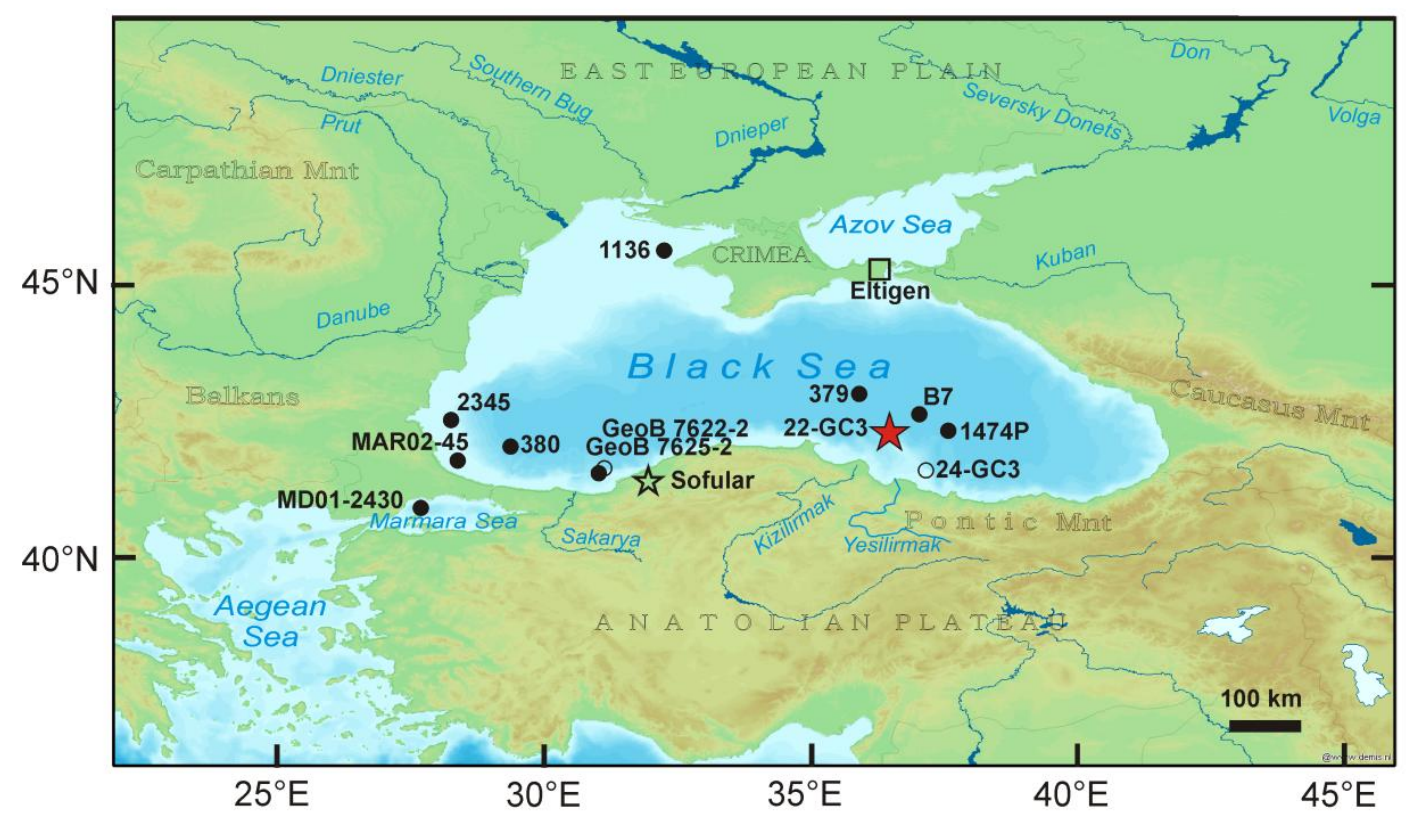

Fig. 1. Physiographic map of the Black Sea region showing locations of the investigated core 22-GC3 (coloured (red) star), cores 24-GC3 and GeoB 7622-2, used for development of the age-depth model (colourless circle), Sofular Cave (colourless star), Eemian stratotype Eltingen (colourless square), marine records of dinocysts, diatoms, foraminifers, coccolithophorids referred to and discussed in the text (black circles). See PDF-file for colours. Map sources: www.bgr.de, www.nowcoast.noaa.gov, www2.demis.nl.

Although interdisciplinary studies on cores taken during the Deep-Sea Drilling Project (DSDP) in 1975 clearly demonstrate several reconnections of the Black Sea basin with the Mediterranean Sea during the Pleistocene (Ross et al., 1978), there is little detailed information on the hydrological conditions in the Black Sea before $25 \mathrm{kyr}$ BP due to a paucity of well-dated sediment records. To fill this gap, we present here the first detailed organicwalled dinoflagellate cyst record that allows semi-quantitative reconstructions of sea-surface conditions of the Black Sea during the last interglacial. Comparison of the Eemian with the 
Holocene section from the same sequence reveals the impact of the Eemian climatic conditions on the Black Sea. In order to verify our dinocyst-based reconstructions for the Eemian and the Holocene, we compare them to the ones based on foraminiferal, mollusc, diatom and coccolith assemblages from published studies.

\section{Oceanographic setting of the Black Sea}

The Black Sea has a surface area of about $4.23 \times 10^{5} \mathrm{~km}^{2}$, a volume of $5.55 \times 10^{5} \mathrm{~km}^{3}$, and a maximal water depth of $\sim 2258 \mathrm{~m}$ (Kosarev and Kostianoy, 2008). The northern part of the basin is characterized by a wide (more than $200 \mathrm{~km}$ ) flat bathymetry (water depth averages $50 \mathrm{~m}$ ). In contrast, the southern coast has a narrow shelf (only a few km wide), with depths increasing abruptly from $100 \mathrm{~m}$ to $1500 \mathrm{~m}$ (Özsoy and Ünlüata, 1997; Kosarev and Kostianoy, 2008). The drainage area of the Black Sea is about $2.5 \times 10^{6} \mathrm{~km}^{2}$, with more than 500 rivers flowing into the basin (Mikhailov and Mikhailova, 2008). Of these, the three largest are the Danube, Dnieper, and Dniester, all of which enter at the north western edge of the basin (Fig. 1).

The Black Sea is the largest meromictic basin in the world, and is characterized by a permanent two-layered water structure. The upper 100-200 m thick layer has a sea-surface salinity (SSS) of around 17-18 due to river discharges, whereas the lower $2000 \mathrm{~m}$ thick layer has a SSS of 22.3 due to the inflow of Mediterranean waters via the Marmara Sea. Temperatures in the Black Sea are characterized by seasonal changes at the surface $\left(3.5-8^{\circ} \mathrm{C}\right.$ in winter and $23.5-25.5^{\circ} \mathrm{C}$ in summer), by the presence of a cold intermediate layer (CIL; temperature $7.2^{\circ} \mathrm{C}$ ), and by a relatively constant temperature in the deeper layers $\left(9.2^{\circ} \mathrm{C}\right)$ (Ginzburg et al., 2008; Tuzhilkin, 2008). The circulation system of the Black Sea surface water (Fig. 2) demonstrates a cyclonal rim gyre with mesoscale western and eastern gyres, and anticyclonal eddies along the coast (Oguz et al., 1993).

At present, the Black Sea has a positive water balance as precipitation $\left(\sim 300 \mathrm{~km}^{3} \mathrm{yr}^{-1}\right)$, river discharge $\left(\sim 350 \mathrm{~km}^{3} \mathrm{yr}^{-1}\right)$ and inflow of Mediterranean water $\left(\sim 300 \mathrm{~km}^{3} \mathrm{yr}^{-1}\right)$ surpass evaporation $\left(\sim 350 \mathrm{~km}^{3} \mathrm{yr}^{-1}\right)$. As a result, the outflow from the Black Sea through the Bosphorus into the Marmara Sea averages $\sim 600 \mathrm{~km}^{3} \mathrm{yr}^{-1}$ (Özsoy and Ünlüata, 1997). 


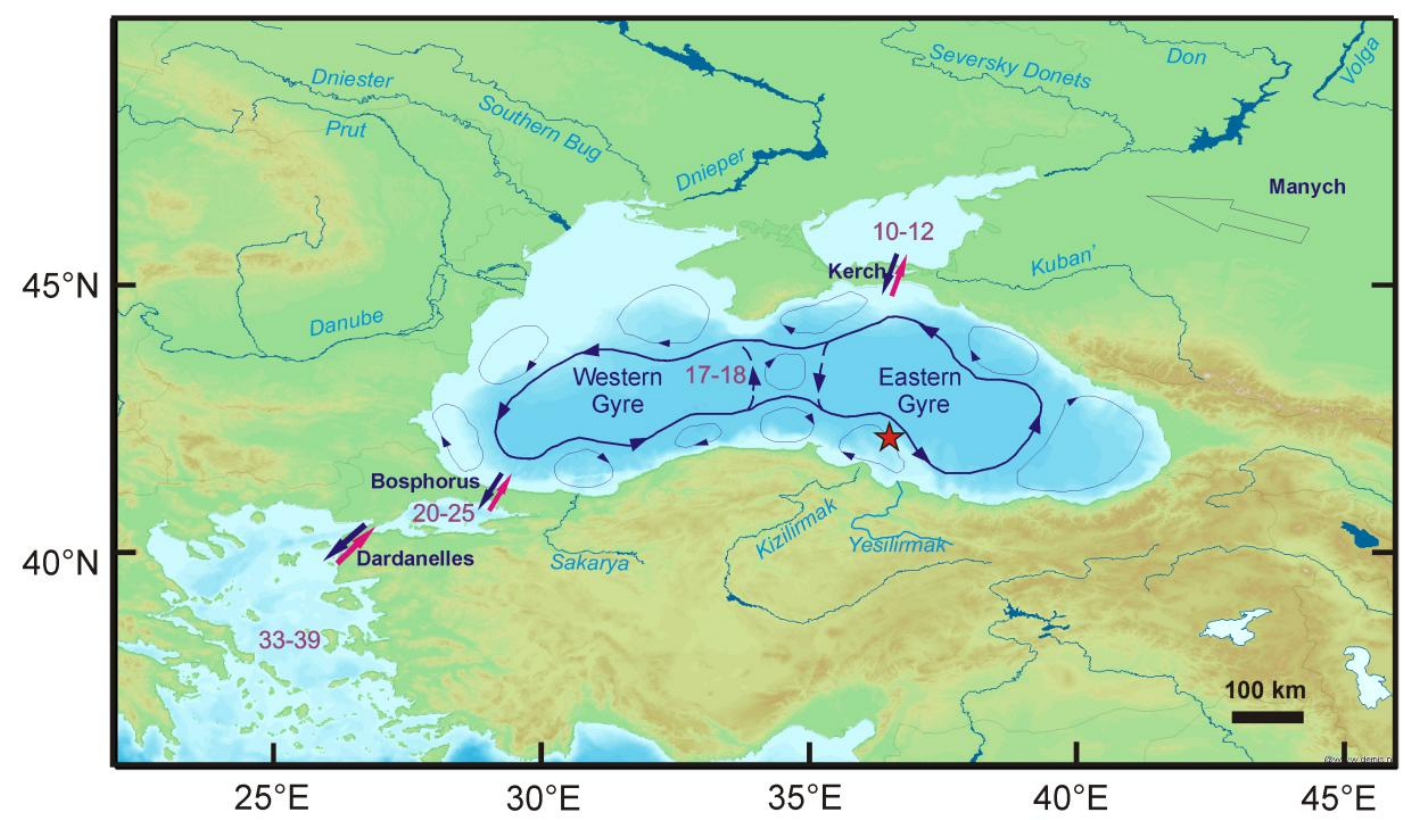

Fig. 2. Map of the Black Sea region showing the surface water general circulation system of the Black Sea (modified from Oguz et al., 1993), main rivers and straits. Thick (blue) lines indicate the main water current with eastern and western gyres, and eddies are indicated by thin (blue) lines. Coloured arrows show direction of in and outflow currents through the Dardanelles, Bosphorus and Kerch straits: left (blue) for less salty surface water, right (purple) for deeper saltier water. Colourless arrow indicates previous connection to the Caspian Sea through Manych. Sea-surface salinities are given in purple numbers from Uçkaç (2005), Beşiktepe et al. (1994), Özsoy and Ünlüata (1997), Kosarev et al. (2008). The coloured (red) star shows the location of core 22-GC3. See PDF-file for colours. Map sources: www.bgr.de, www.nowcoast.noaa.gov, www2.demis.nl.

The water exchange between the Black and Marmara Sea occurs in two layers: a subsurface inflow of Mediterranean and shallow outflow of Black Sea water. Warm $\left(14.5^{\circ} \mathrm{C}\right)$, highly saline (37) Mediterranean waters enter the Black Sea basin through the Bosphorus Strait, with the flow following the relief of the shelf and mixing with the overlaying CIL, becoming colder $\left(9.2^{\circ} \mathrm{C}\right)$ and less saline (22.3) and sinking along the continental slope (Özsoy and Ünlüata, 1997; Murray et al., 2005). Due to the permanent pycno- and haloclines, annual renewal of the water occurs only to a depth of approximately 60-80 m (e.g. Debol'skaya et al., 2007; Tuzhilkin, 2008); the water column below a depth of 100-200 m represents a hydrogen sulphide zone, in which only anoxic processes take place (Kosarev and Kostianoy, 2008), allowing good preservation of organic matter.

Besides salinity and temperature, surface layer characteristics such as light and nutrients are very important for dinoflagellate distribution. According to Yayla et al. (2001), light penetrates in the southern Black Sea into the upper 20-35 m. Under optimum light conditions, phytoplankton growth rate is governed by the concentration of essential nutrients (Yunev et al., 2002; Nezlin, 2008; Stel'makh et al., 2009), depending on the thermal stratification and 
mixing processes of the surface water. Intensive solar heating initiates surface water stratification in summer. The vertical mixing of summer stratified waters occurs mostly by CIL formation in winter, transporting heat and oxygen into the deeper water as well as nutrients upwards into the photic layer (Yunev et al., 2005). Eddy dynamics (Zatsepin et al., 2007) and upwelling along the Anatolian coast (e.g. Özsoy and Ünlüata, 1997) intensify mixing processes of surface water in summer.

\section{Material and methods}

Cores 22-GC3 $(839 \mathrm{~cm})$ and 22-GC8 $(943 \mathrm{~cm})$ were taken during the RV METEOR cruise M72/5 in 2007 from the slope of the Arkhangelsky Ridge in the southeastern Black Sea $\left(42^{\circ} 13.53^{\prime} \mathrm{N} / 36^{\circ} 29.55^{\prime} \mathrm{E}, 838 \mathrm{~m}\right.$ water depth) (Fig. 1). The coring site is located $70-75 \mathrm{~km}$ north-east of the Turkish coast, where the Kızılırmak and Yeşilırmak rivers flow into the Black Sea.

\subsection{Chronology}

Cores 22-GC3 and 22-GC8 were combined to a composite depth (Table 1) due to the fact that core 22-GC3 contains a more complete Eemian sapropel but core 22-GC8 had a deeper penetration into lacustrine sediments of the penultimate glacial. The cores were therefore combined at the level of the onset of the Eemian sapropel $(820.5 \mathrm{~cm}$ in core $22-\mathrm{GC} 3$ and $809.5 \mathrm{~cm}$ in core 22-GC8) using visual core inspection supported also by magnetic susceptibility and XRF logger data. A systematic correction of $+11 \mathrm{~cm}$ has been applied to the 22-GC8 core below this reference depth (Table 1). The stratigraphic anchor-points for the last glacial - Holocene and the penultimate glacial- Eemian in sediment cores 22-GC3 and 22GC8 are provided in Table 1. The age-depth model for the upper part of the core 22-GC3 (391 $\mathrm{cm}$ ) was presented in Shumilovskikh et al. (2012), in which further details about the core can be found. Because bulk carbonate and organic carbon are very sensitive to terrestrial contamination (e.g. Jones and Gagnon, 1994; Lamy et al., 2006), ages for the uppermost 47 $\mathrm{cm}$ were obtained using direct lithological correlation (Unit I, II and III) with core GeoB $7622-2\left(41^{\circ} 26.70^{\prime} \mathrm{N}, 31^{\circ} 04.00^{\prime} \mathrm{E}\right)$. The latter was radiocarbon (nine ${ }^{14} \mathrm{C}$ accelerator mass spectrometry; AMS) dated on well preserved larval shells of the shallow marine mollusc Mytilus galloprovincialis and organic matter (Lamy et al., 2006). 
Table 1. Stratigraphical control points for sediment cores $22-\mathrm{GC} 3^{(1)}$ and $22-\mathrm{GC} 8^{(2)}$.

\begin{tabular}{|c|c|c|c|}
\hline $\begin{array}{l}\text { Original } \\
\text { depth }(\mathrm{cm})\end{array}$ & $\begin{array}{l}\text { Composite } \\
\text { depth }(\mathrm{cm})\end{array}$ & Description & $\begin{array}{c}\text { Age } \\
(\text { cal kyrs BP) }\end{array}$ \\
\hline \multicolumn{4}{|c|}{ Last glacial - Holocene } \\
\hline $0^{1}$ & 0 & surface of the core is assumed to be of modern age & 0 \\
\hline $14^{1}$ & 14 & Unit I, final coccolith invasion, ages from Lamy et al. (2006) & 1.7 \\
\hline $20^{1}$ & 20 & Unit I, first coccolith invasion, ages from Lamy et al. (2006) & 2.7 \\
\hline $47^{1}$ & 47 & Unit II / III boundary, ages from Lamy et al. (2006) & 8.3 \\
\hline $55^{1}$ & 55 & Basis of Holocene, age from Kwiecien et al. (2008) & 11.7 \\
\hline $74^{1}$ & 74 & ${ }^{14} \mathrm{C}$ AMS age from core $24-\mathrm{GC} 3$ linked through $\mathrm{XRF} \mathrm{Ca}$ and $\mathrm{Ti} / \mathrm{Ca}$ to $22-\mathrm{GC} 3$ & 12.6 \\
\hline $79^{1}$ & 79 & ${ }^{14} \mathrm{C}$ AMS age from core $24-\mathrm{GC} 3$ linked through $\mathrm{XRF} \mathrm{Ca}$ and $\mathrm{Ti} / \mathrm{Ca}$ to $22-\mathrm{GC} 3$ & 13.7 \\
\hline $80^{1}$ & 80 & ${ }^{14} \mathrm{C}$ AMS age from core $24-\mathrm{GC} 3$ linked through $\mathrm{XRF} \mathrm{Ca}$ and $\mathrm{Ti} / \mathrm{Ca}$ to $22-\mathrm{GC} 3$ & 14.0 \\
\hline $81^{1}$ & 81 & ${ }^{14} \mathrm{C}$ AMS age from core $24-\mathrm{GC} 3$ linked through $\mathrm{XRF} \mathrm{Ca}$ and $\mathrm{Ti} / \mathrm{Ca}$ to $22-\mathrm{GC} 3$ & 14.4 \\
\hline $121^{1}$ & 121 & ${ }^{14} \mathrm{C}$ AMS age from core $24-\mathrm{GC} 3$ linked through $\mathrm{XRF}$ Ti/Ca to $22-\mathrm{GC} 3$ & 15.0 \\
\hline $227^{1}$ & 227 & ${ }^{14} \mathrm{C}$ AMS age from core $24-\mathrm{GC} 3$ linked through $\mathrm{XRF}$ Ti/Ca to $22-\mathrm{GC} 3$ & 16.8 \\
\hline $303^{1}$ & 303 & ${ }^{14} \mathrm{C}$ AMS age from core $24-\mathrm{GC} 3$ linked through XRF Ti/Ca to $22-\mathrm{GC} 3$ & 17.9 \\
\hline $333^{1}$ & 333 & ${ }^{14} \mathrm{C}$ AMS age from core $24-\mathrm{GC} 3$ linked through $\mathrm{XRF}$ Ti/Ca to $22-\mathrm{GC} 3$ & 18.6 \\
\hline \multicolumn{4}{|c|}{ Penultimate glacial - Eemian } \\
\hline $794^{1}$ & 794 & $\begin{array}{l}\text { pollen-stratigraphic correlations to Monticchio (Allen and Huntley, 2009) and Ioannina } 284 \\
\text { (Tzedakis et al., 2003) pollen records }\end{array}$ & 123 \\
\hline $812^{1}$ & 812 & $\begin{array}{l}\text { pollen-stratigraphic correlations to Monticchio (Allen and Huntley, 2009) and Ioannina } 284 \\
\text { (Tzedakis et al., 2003) pollen records }\end{array}$ & 127.5 \\
\hline $809.5^{2}$ & 820.5 & $\begin{array}{l}\text { correlation of ostracod } \delta^{18} \mathrm{O} \text { record with }{ }^{230} \mathrm{Th} \text { dated Sofular Cave } \delta^{18} \mathrm{O} \text { record (Badertscher et } \\
\text { al., 2011) }\end{array}$ & 128.8 \\
\hline $821.5^{2}$ & 832.5 & $\begin{array}{l}\text { correlation of ostracod } \delta^{18} \mathrm{O} \text { record with }{ }^{230} \mathrm{Th} \text { dated Sofular Cave } \delta^{18} \mathrm{O} \text { record (Badertscher et } \\
\text { al., 2011) }\end{array}$ & 130.4 \\
\hline $848.5^{2}$ & 859.5 & $\begin{array}{l}\text { correlation of ostracod } \delta^{18} \mathrm{O} \text { record with }{ }^{230} \mathrm{Th} \text { dated Sofular Cave } \delta^{18} \mathrm{O} \text { record (Badertscher et } \\
\text { al., 2011) }\end{array}$ & 131 \\
\hline $905.5^{2}$ & 916.5 & $\begin{array}{l}\text { correlation of ostracod } \delta^{18} \mathrm{O} \text { record with }{ }^{230} \mathrm{Th} \text { dated Sofular Cave } \delta^{18} \mathrm{O} \text { record (Badertscher et } \\
\text { al., 2011) }\end{array}$ & 132.7 \\
\hline
\end{tabular}

The anchor points for the marine unit of core 22-GC3 are the transition from Unit III to Unit II at $8.3 \mathrm{kyr} \mathrm{BP}$, as well as the first (2.7 kyr BP) and final (1.7 kyr BP) coccolith invasion (Fig. 3). Since the abundance of datable bivalve and ostracod shells in the Black Sea sediments strongly decreases with increasing water depth due to the preferentially shallow water depth habitat of these organisms, several attempts to extract enough datable shell carbonate material from sediment core 22-GC3 were not successful. In order to overcome this problem, we exported for the chronostratigraphy of the late glacial lacustrine Unit III sediments a sequence of 8 ostracod ${ }^{14} \mathrm{C}$-AMS ages from the shallower nearby sediment core 
24-GC3 (412 $28.66^{\prime} \mathrm{N}, 37^{\circ} 11.68^{\prime} \mathrm{E}$; $208 \mathrm{~m}$ waster depth) (Table 2) to sediment core 22-GC3 through a detailed correlation of XRF measurements on both cores (Fig. 3). XRF Ca intensities and particularly $\mathrm{Ti} / \mathrm{Ca}$ ratios have been proven as useful correlation tools for the late glacial sediment sequences of Black Sea sediment cores (Bahr et al., 2006; Kwiecen et al., 2008, 2009).

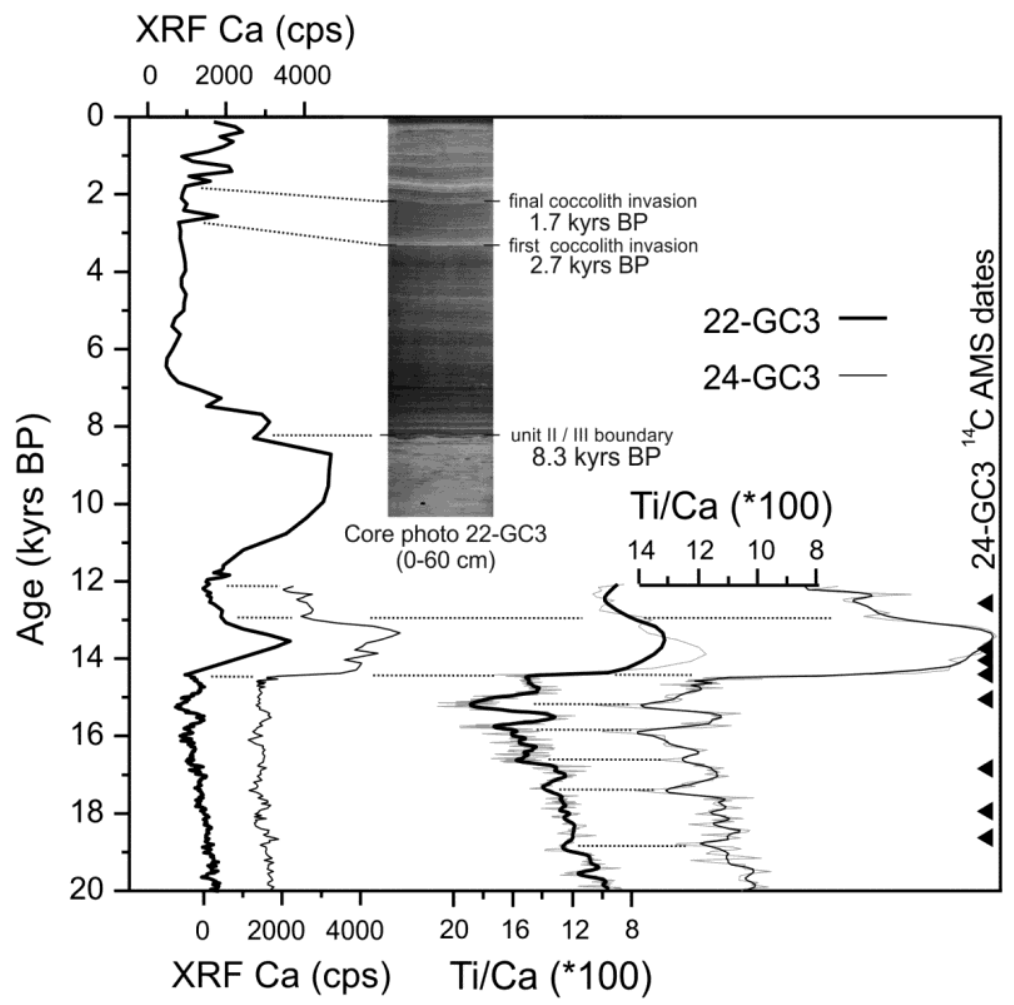

Fig. 3. Correlation between XRF $\mathrm{Ca}$ and Ti/Ca records of the cores 24-GC3 and 22-GC3 used to transfer the ${ }^{14} \mathrm{C}$ age control points (black triangles) from 24-GC3 to 22-GC3. Tie points are indicated with dotted lines. Inlay shows the image for the uppermost $60 \mathrm{~cm}$ of the core indicating the three lithostratigraphic pointers with the respective ages from Lamy et al. (2006).

The chronology for penultimate glacial transition and beginning of the Eemian in core 22-GC8 is based on the correlation of its $\delta^{18} \mathrm{O}$ ostracod record with the ${ }^{230} \mathrm{Th}$ dated speleothem $\delta^{18} \mathrm{O}$ record from Sofular Cave in northwestern Anatolia (Badertscher et al., 2011) (Fig. 4). $\delta^{18} \mathrm{O}$ was measured on ostracod valves of Candona spp. picked from the $150 \mu \mathrm{m}$ fraction, and analyzed using a Finnigan MAT 253 mass spectrometer with an automated KIEL IV carbonate preparation device. In addition, the chronology for the Eemian section of cores 22-GC3/8 was established by correlating its pollen record with pollen records from Ioannina 284 (Tzedakis et al., 2003) and Monticchio Lake (Allen and Huntley, 2009) from Greece and Italy respectively. For chronology, two anchor points were used. The first chronological anchor point is the arboreal pollen maximum of $\sim 90 \%$ in the $22-\mathrm{GC} 3$ (Fig. $6 \mathrm{~F}$ ) 
correlated to Monticchio ( $\sim 80 \%)$ and Ioannina $284(\sim 90 \%)$ arboreal pollen maxima at $\sim 127.5$ kyr BP.

Table 2. Radiocarbon dates for $24-\mathrm{GC} 3 .{ }^{14} \mathrm{C}$ ages were converted into calibrated calendar ages before present, defined as AD 1950, using the Calib 6.0 radiocarbon calibration tools with the INTCAL09 calibration curve. Reservoir ages were adopted from Kwiecien et al. (2008). For additional details see Shumilovskikh et al. (2012) and Nowaczyk et al. (2012).

\begin{tabular}{|c|c|c|c|c|c|}
\hline $\begin{array}{l}\text { Core depth } \\
(\mathrm{cm})\end{array}$ & Lab-ID & $\begin{array}{l}{ }^{14} \mathrm{C} \text { age } \\
\text { (kyrsBP) }\end{array}$ & 1sigma error & $\begin{array}{c}\text { Reservoir age } \\
\text { (kyrs) }\end{array}$ & $\begin{array}{l}\mathrm{cal}^{14} \mathrm{C} \text { age } \\
(\mathrm{kyrs} B P)\end{array}$ \\
\hline 148 & ETH-35501 & 10,595 & 60 & 0.00 & 12.57 \\
\hline 187 & ETH-35502 & 12,385 & 65 & 0.50 & 13.74 \\
\hline 197 & ETH-35503 & 13,205 & 65 & 1.00 & 14.05 \\
\hline 210 & ETH-35504 & 13,330 & 65 & 1.00 & 14.41 \\
\hline 240 & ETH-35505 & 13,700 & 65 & 1.00 & 15.05 \\
\hline 313 & ETH-35506 & 15,165 & 75 & 1.45 & 16.84 \\
\hline 350 & ETH-35507 & 16,245 & 80 & 1.45 & 17.95 \\
\hline 391 & ETH-35508 & 16,835 & 85 & 1.45 & 18.63 \\
\hline
\end{tabular}

The second chronological anchor point is the distinct increase in euxinian vegetation percentages in the 22-GC3/8 record, mainly Fagus (up to 25\%; Fig. 6F) correlated to the second arboreal pollen maximum ( $90 \%)$ in Monticchio record and the increase in Carpinus betulus (up to 40\%) in the Ioannina 284 record at $123 \mathrm{kyr}$ BP. Ages for the studied sections of core 22-GC3/8 were then calculated using linear interpolation between the anchor-points.

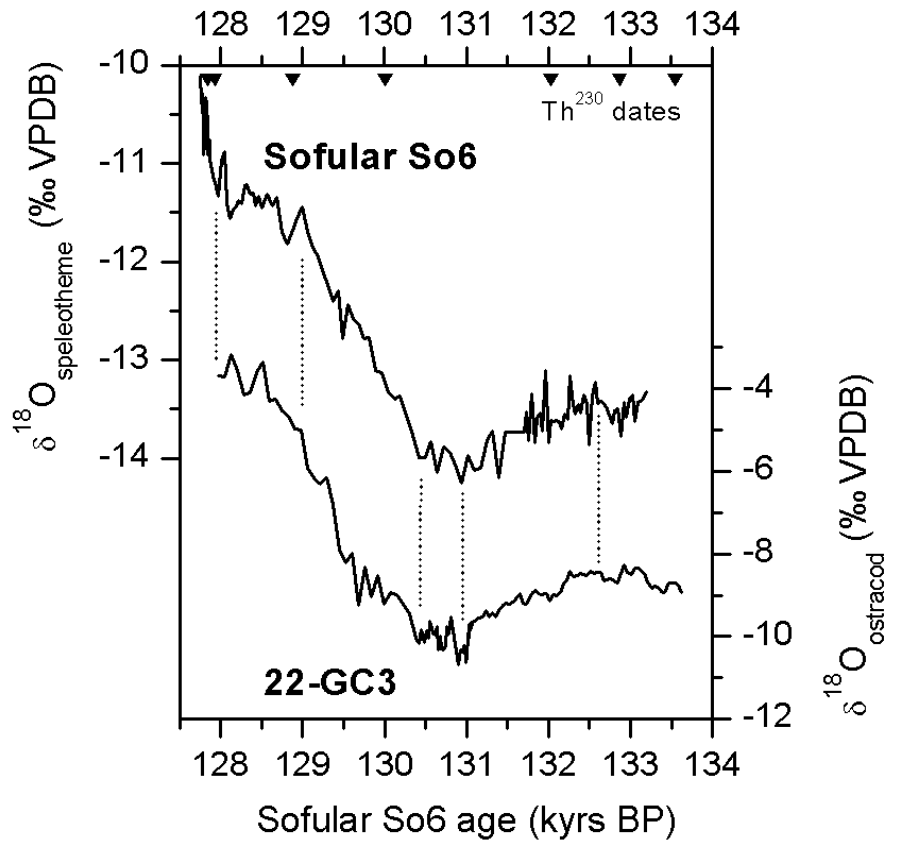

Fig. 4. Correlation of ostracod $\delta^{18} \mathrm{O}$ record with the $\mathrm{Th}^{230}$ dated (black triangles) Sofular Cave $\delta^{18} \mathrm{O}$ record (Badertscher et al., 2011). Tie points are indicated with dotted lines. 


\subsection{Analysis of organic-walled dinoflagellate cysts}

To compare the hydrological conditions of the Black Sea during the Holocene and Eemian, core 22-GC3 was sampled from the top to $52 \mathrm{~cm}$ (Holocene) at $2 \mathrm{~cm}$ intervals and from 780 to $820 \mathrm{~cm}$ (Eemian) at $1 \mathrm{~cm}$ intervals. A total of 68 samples of $0.5-1 \mathrm{~cm}^{3}$ each were collected, oven dried $\left(60{ }^{\circ} \mathrm{C}\right)$ for one night and prepared using standard methods. The treatment included demineralisation with cold hydrochloric acid (10\%), followed by cold hydrofluoric acid (70\%) over two nights and sieving at $10 \mu \mathrm{m}$ on a nylon mesh. To calculate the cyst concentration, one tablet of Lycopodium spores (batch number 177745; consists of $18584 \pm 371$ spores) was added to each sample at the beginning of the preparation. Identifications were carried out under x400 magnification. A minimum of 300-350 specimens were counted for each sample.

Dinoflagellate cyst taxonomy is based on Wall et al. (1973), Rochon et al. (1999) and Marret et al. (2004). Cysts of Caspidinium rugosum possibly include morphological and ecologically similar cysts of Gonyaulax apiculata, unambiguous identification of which was impossible due to their poor preservation. Since the mean size of cysts of Gymnodinium is 27.75 $\pm 3.23 \mu \mathrm{m}$ (median $28.5 \mu \mathrm{m}$, minimum $22.5 \mu \mathrm{m}$, maximum $32.5 \mu \mathrm{m}$ ), these cysts were grouped as Gymnodinium microreticulatum/nolleri. The calculation of dinocyst percentages is based on the total sum of identified organic-walled dinoflagellate cysts per sample (308 \pm 9$)$. In addition to dinocysts, other algae and common marine acritarchs and non-pollen palynomorphs (NPP) (e.g. Botryococcus, Cymatiosphaera sp., Pterospermella) (see Plate 3) were counted (Mudie et al., 2011) and expressed as percentages of the dinocyst sum. Dinocyst counts are available under the name of the corresponding author through the PANGAEA server (www.pangaea.de). Based on the important changes in the relative abundance of dinocyst key species, diagrams were divided into local zones. The diagrams were designed using the software C2 data analysis Version 1.6.6 (Juggins, 2007) (Fig. 5).

For the semi-qualitative reconstruction of hydrological changes at the core site, taxa percentages were summed into several groups according to their modern distribution and ecological preferences (e.g. Marret and Zonneveld, 2003; Marret et al., 2004) (Fig. 6). The "thermophilic" group includes cysts with subtropical / tropical distribution (Tuberculodinium vancampoae, Spiniferites pachydermus, Spiniferites mirabilis, Tectatodinium pellitum, cysts of Polykrikos schwartzii, and cysts of Protoperidinium stellatum) (Fig. 6E). "Fully marine" taxa include dinocysts occurring at SSS >28.5 (Spiniferites pachydermus, Spiniferites mirabilis, Bitectatodinium tepikiense, Tectatodinium pellitum, Ataxiodinium choane, and cysts of Polykrikos schwartzii, Spiniferites bentorii, Xandarodinium xanthum) (Fig. 6E). 

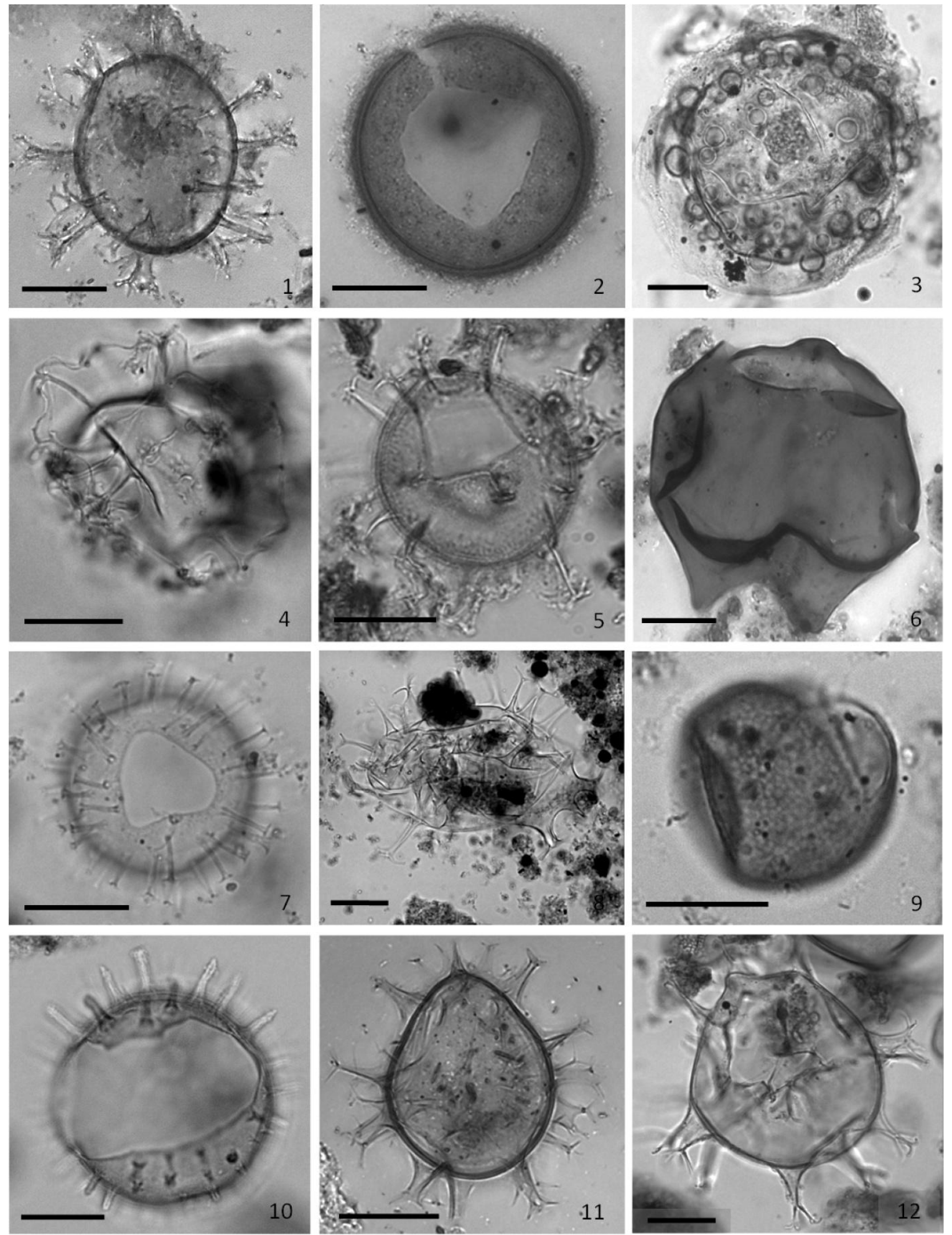

Plate 1. Light microscope photographs of selected dinocysts from core 22-GC3, scale bar is $20 \mu \mathrm{m}$ : 1 - Achomosphaera cf andalousiense (30 cm, combined foci); 2 - Tectatodinium pellitum (806 cm, combined foci); 3 - Tuberculodinium vancampoae $(812 \mathrm{~cm}$, optical section); 4 - Nematosphaeropsis labyrinthus (783 cm, optical section); 5 - Spiniferites pachydermus (806 cm, high focus); 6 - Quinquecuspis concreta (784 cm, combined foci); 7 Operculodinium centrocarpum $(783 \mathrm{~cm}$, high foci); 8 - Spiniferites mirabilis $(784 \mathrm{~cm}$, optical section); 9 - cyst of Gymnodinium microreticulatum $/$ nolleri (41cm, high focus); 10 Lingulodinium machaerophorum (74 cm, high focus); 11 - Spiniferites ramosus s.1. $(779 \mathrm{~cm}$, combined foci); 12 - Spiniferites bentorii (783 cm, optical section). 


\section{Results}

4.1 Holocene dinocyst record

The Holocene sequence, presented on Figure 5a, can be divided into 4 local biozones (LZ).

$\underline{\mathrm{LZ} H 1}(52-47 \mathrm{~cm}, 10.6$ to $8.4 \mathrm{kyr} \mathrm{BP})$ is dominated by the freshwater/brackish species Pyxidinopsis psilata (91-97\%) with occurrence of Spiniferites cruciformis (3-8\%) and Caspidinium rugosum ( $<1 \%$ ). Cyst concentrations range from 4,135 to 6,360 cysts $/ \mathrm{cm}^{3}$.

$\underline{\mathrm{LZ} \mathrm{H} 2}(47-33 \mathrm{~cm}, 8.4$ to $5.4 \mathrm{kyr} \mathrm{BP})$ is characterized by an abrupt change from low diverse (three species) freshwater/brackish to high diverse (13 species) marine assemblages. This zone has been divided in two subzones. Subzone H2a $(47-41 \mathrm{~cm}, 8.4$ to $7 \mathrm{kyr}$ BP) is dominated by Spiniferites species: Spiniferites ramosus (25-42\%), Spiniferites belerius (15$43 \%$ ) and Spiniferites bentorii (4-12\%). Dinocyst concentrations are up to $19,160 \mathrm{cysts} / \mathrm{cm}^{3}$. Subzone H2b (41-33 cm, 7 to $5.4 \mathrm{kyr}$ BP) is characterized by an abrupt increase of dinocyst concentrations $\left(49,020-87,770\right.$ cysts $\left./ \mathrm{cm}^{3}\right)$ and elevated percentages of Lingulodinium machaerophorum (63-96\%). Cymatiosphaera sp. reaches its maximum (42\%).

$\underline{\mathrm{LZ} \mathrm{H} 3}(33-9 \mathrm{~cm} ; 5.4$ to $1.1 \mathrm{kyr} \mathrm{BP})$ is characterized by an abrupt decrease of cyst concentrations $\left(1,527-25,890 \mathrm{cysts} / \mathrm{cm}^{3}\right)$ as well as by an increase in percentages of peridinoid cysts up to $31 \%$. Dominant species in zone 3 are Lingulodinium machaerophorum (19-68\%) and Spiniferites ramosus (12-27\%). This zone has been divided in two subzones. In subzone H3a (33-19 cm; 5.4 to $2.5 \mathrm{kyr}$ BP) maximum peaks of Operculodinium centrocarpum (22\%), cysts of Pentapharsodinium dalei (14\%) and heterotrophic species Quinquecuspis concreta (16\%) and Peridinium ponticum (9\%) are apparent. This subzone is characterized by the first occurrence of several heterotrophic dinocyst species (Peridinium ponticum, Brigantedinium simplex, cysts of Polykrikos schwartzii, Echinidinium spp., cysts of Protoperidinium stellatum, Xandarodinium xanthum and cysts of Cochlodinium sp.) as well as acritarchs and NPPs (Tasmanites, Type BS2, Type BS3, Cobricosphaeridinium spiniferum). The characteristic features for subzone H3b (19-9 cm; 2.5 to $1.1 \mathrm{kyr}$ BP) are peaks of Spiniferites mirabilis (12\%), Spiniferites bentorii (12\%) and peridinoids Peridinium ponticum (10\%) and cysts of Gymnodinium microreticulatum/nolleri (5\%). Moreover, peridinoid cysts of Protoperidinium nudum and Echinidinium zonneveldiae and acritarch Hexasterias problematica occur for the first time. 

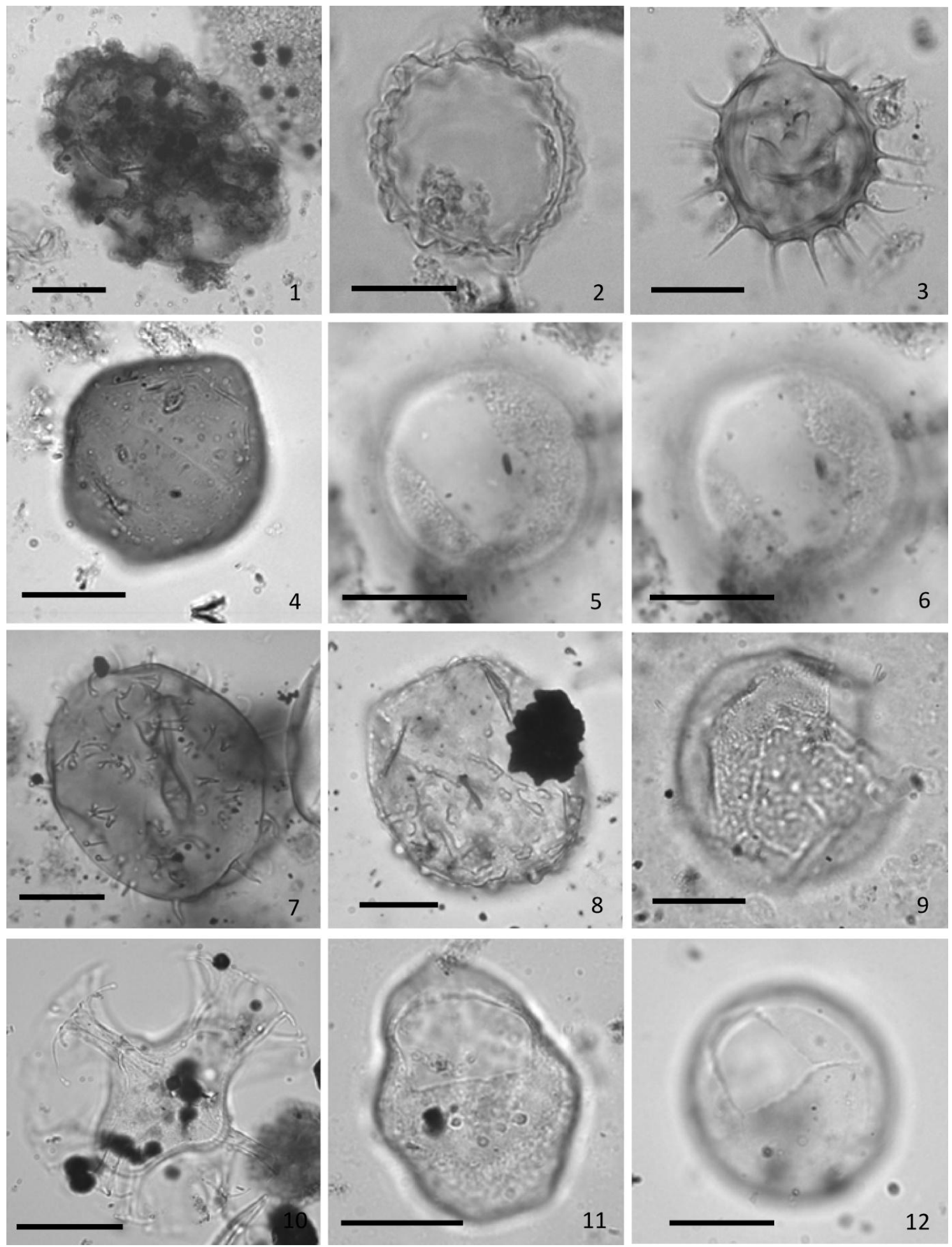

Plate 2. Light microscope photographs of selected dinocysts from core 22-GC3, scale bar is $20 \mu \mathrm{m}$ : 1 - Cyst of Polykrikos cf. schwartzii (5 cm, combined foci); 2 - Ataxiodinium choane (30 cm, combined foci); 3 - Cyst of Protoperidinium nudum (35 cm, optical section); 4 Peridinium ponticum (28 cm, combined foci); 5 - Bitectatodinium tepikiense ( $802 \mathrm{~cm}$, optical section); 6 - Bitectatodinium tepikiense ( $802 \mathrm{~cm}$, high focus); 7 - Echinidinium zonneveldiae ( $2 \mathrm{~cm}$, high focus); 8 - Caspidinium rugosum $(818 \mathrm{~cm}$, combined foci); 9 - Caspidinium rugosum ( $818 \mathrm{~cm}$, high focus); 10 - Spiniferites cruciformis (48 cm, high focus); 11 Pyxidinopsis psilata (818 cm, optical section); 12 - Pyxidinopsis psilata (818 cm, high focus). 
$\underline{\mathrm{LZ} \mathrm{H} 4}(9-0.5 \mathrm{~cm} ; 1.1 \mathrm{kyr} \mathrm{BP}$ - present) is indicated by a significant change of dominant taxa. Peridinium ponticum reaches $25-55 \%$, while percentages of Lingulodinium machaerophorum declines to $18 \%$ and Spiniferites ramosus stays below 13\%. Relative abundance of some heterotrophics increases towards the end of the zone: cysts of Gymnodinium microreticulatum/nolleri (6\%), cysts of Polykrikos schwartzii (3\%), cysts of Protoperidinium stellatum (3\%), whereas Tectatodinium pellitum disappears. Cyst concentrations are low $\left(3,752-6,637 \mathrm{cysts} / \mathrm{cm}^{3}\right)$.

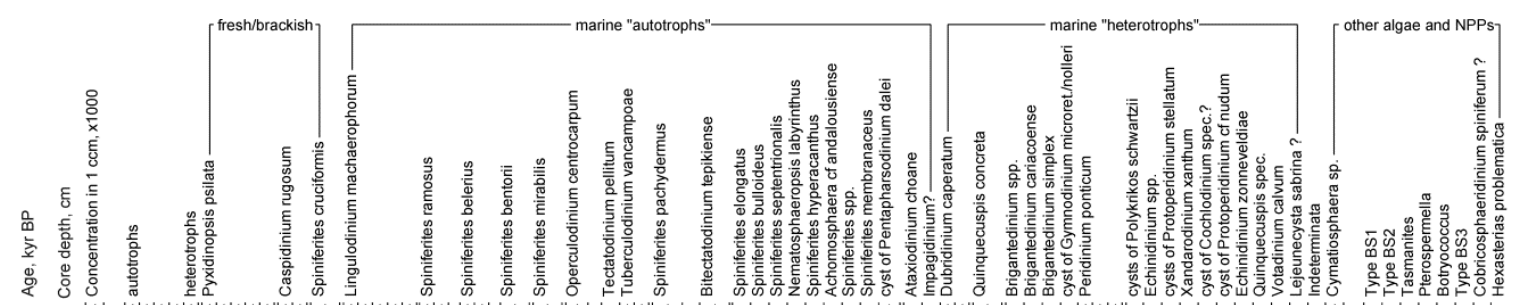

a)
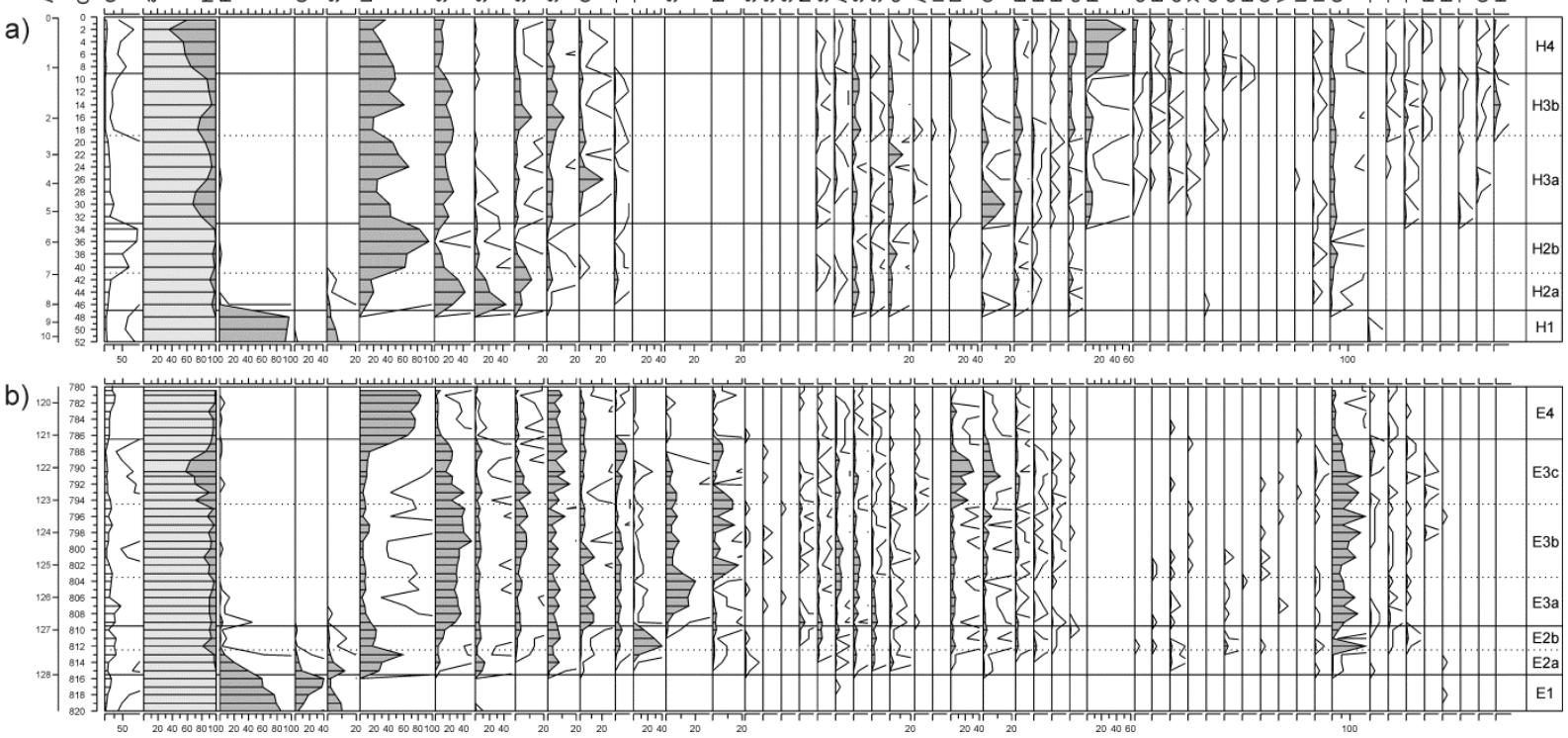

Fig. 5. Percentage diagram of dinocysts, other algae and NPPs in the Holocene (a) and Eemian (b) sections of the core 22-GC3. A $\times 10$ exaggeration of the horizontal scale is used to show changes in low taxa percentages.

\subsection{Eemian dinocyst record}

The Eemian sequence, presented on Figure 5b, is divided into four LZ.

$\underline{\mathrm{LZ} \text { E1 }}(820-815.5 \mathrm{~cm} ; 128.7$ to $128 \mathrm{kyr} \mathrm{BP})$ is characterized by very low numbers of species (five). The assemblages are dominated by freshwater/brackish species Pyxidinopsis psilata, Caspidinium rugosum, Spiniferites cruciformis with occasional and discrete occurrences of the freshwater algae Botryococcus. Total concentrations of dinocysts increase gradually from 3,711 to 18,400 cysts $/ \mathrm{cm}^{3}$. The dominant species Pyxidinopsis psilata reaches 
$85 \%$ at the depth of $820 \mathrm{~cm}$, and is then replaced by Caspidinium rugosum, which reaches $40 \%$ at $816 \mathrm{~cm}$.

$\underline{\text { LZ E2 }}(815.5-809.5 \mathrm{~cm} ; 128-126.9 \mathrm{kyr} \mathrm{BP})$ is characterised by an abrupt increase in species number up to 27 taxa and by maxima of marine species Lingulodinium machaerophorum (up to 59\%) and Tuberculodinium vancampoae (up to 40\%). Dinocyst concentrations vary between $7,601-38,170 \mathrm{cysts} / \mathrm{cm}^{3}$. This zone has been divided into two subzones. Subzone E2a (815.5-812.5 cm; 128-127.6 kyr BP) is dominated by Lingulodinium machaerophorum (27-59\%), Pyxidinopsis psilata (6-40\%) and Spiniferites belerius (up to $13 \%$ ), and characterised by the first occurrence of fully marine species Spiniferites mirabilis, Bitectatodinium tepikiense and Tectatodinium pellitum. In subzone E2b $(812.5-809.5 \mathrm{~cm}$; 127.6-126.9 kyr BP), the relative abundance of Lingulodinium machaerophorum decreases (17-23\%), whereas Tuberculodinium vancampoae reaches its maximum (14-40\%). In this subzone, the acritarch Cymatiosphaera sp. achieves a maximum of $183 \%$. In the upper part of subzone E2b, Tectatodinium pellitum, Bitectatodinium tepikiense, Spiniferites bentorii, Spiniferites pachydermus, Spiniferites hyperacanthus, Nematosphaeropsis labyrinthus reach $1-2 \%$.

$\underline{\text { LZ E3 }}$ (809.5-786.5 cm; 126.9-121.1 kyr BP) is dominated by Spiniferites species especially by Spiniferites ramosus (15-49\%), while Lingulodinium machaerophorum achieves only $3-14 \%$. The relative abundance of Cymatiosphaera sp. is very high (43-183\%). Cyst concentrations vary from 3,200 to $23,260 \mathrm{cysts} / \mathrm{cm}^{3}$. This zone has been divided into three subzones. In subzone E3a (809.5-803.5 cm; 126.9-125.3 kyr BP), the fully marine tropical species Spiniferites pachydermus increases gradually from 2 to 20\%. Subzone E3b (803.5$794.5 \mathrm{~cm} ; 125.3-123.1 \mathrm{kyr} \mathrm{BP})$ is characterised by an increase of fully marine cool/temperate species Bitectatodinium tepikiense up to $17 \%$ and relatively high percentages of Spiniferites pachydermus (9\%), Tectatodinium pellitum (5\%), Spiniferites bentorii (8\%). Subzone E3c (794.5-786.5 cm; 123.1-121.1 kyr BP) is indicated by high abundance of heterotrophic peridinoid cysts (up to $42 \%$ ) with the dominance of Dubridinium caperatum (5-32\%) and Quinquecuspis concreta (3-12\%). Spiniferites pachydermus decreases slowly (0-7\%), whereas the relative abundance of Bitectatodinium tepikiense varies from 0.5 to $13 \%$.

$\underline{\text { LZ E4 }}(786.5-780 \mathrm{~cm} ; 121.1-119.5 \mathrm{kyr} \mathrm{BP})$ is characterized by the dominance of the eurythermic and euryhaline species Lingulodinium machaerophorum (66-84\%). The fully marine species Spiniferites pachydermus, Bitectatodinium tepikiense, Tectatodinium pellitum, and Spiniferites bentorii occur less often and the abundance of heterotrophic cysts is very low $(10 \%)$. Cyst concentration increases up to 27,430 cysts $/ \mathrm{cm}^{3}$. 


\section{Discussion}

In the following sections we will discuss the nature of hydrological changes in the Black Sea during the Holocene and the Eemian, with special emphasis on changes in SSSs and SSTs.

\subsection{Change in the southern Black Sea sea-surface conditions during the Holocene}

Between 11 and $8.3 \mathrm{kyr} \mathrm{BP}$, dinocyst assemblages consist of fresh / brackish water indicators such as Pyxidinopsis psilata, Spiniferites cruciformis and Caspidinium rugosum (Fig. 5a, LZ H1). As Spiniferites cruciformis, Pyxidinopsis psilata and Caspidinium rugosum are present in the Caspian Sea at SSSs of around 12-13 and Pyxidinopsis psilata in the Baltic Sea at SSSs of 12 (Yu and Berglund, 2007), we suggest a maximum SSS of around 12 during the lacustrine stage of the Black Sea. This estimate is validated by other dinocyst records from the Black Sea, which all indicate freshwater / brackish conditions prior to the inflow of Mediterranean water into the Black Sea (Wall et al., 1973; Wall and Dale, 1974; Mudie et al., 2001, 2002, 2004; Atanassova, 2005; Filipova-Marinova, 2006; Mudie et al., 2007; Marret et al., 2009; Verleye et al., 2009). Yanko-Hombach (2007) evaluated foraminiferal, mollusc and interstitial water records and provided a narrower salinity range of 4-12 for the lacustrine (Neoeuxinian) stage. Furthermore, the sporadic presence of Emiliania huxleyi (SSS range 1141; Bukry et al., 1974) in the early Holocene part of several cores from the western Black Sea (Giunta et al., 2007) may indicate brackish and not freshwater conditions.

The composition of the dinocyst assemblages in core 22-GC3 changes at $\sim 8.3 \mathrm{kyr}$ BP and the dominance of Spiniferites ramosus and Lingulodinium machaerophorum indicates more saline conditions with estimates of 9-18 (Wall and Dale, 1974) or 14-18 (Mudie et al., 2001) (Fig. 5a, 6D). The sporadic occurrence of the fully marine species Xandarodinium xanthum and Tectatodinium pellitum (Marret and Zonneveld, 2003) between 5.4 and $2.5 \mathrm{kyr}$ BP suggests the highest SSSs (possibly 20) during this time, whereas disappearance of these species after $2.5 \mathrm{kyr}$ BP is an evidence for decrease in SSSs. Additional evidence for the freshening of sea surface conditions during the last millennia is the spreading of the brackish water indicator Peridinium ponticum, known from the Oslofjord (Dale, 1996). Our findings are in accordance with the GeoB 7625-2 record, where occurrence of Xandarodinium xanthum between $\sim 5.2$ and $2.3 \mathrm{kyr}$ BP and increase of Peridinium ponticum after $2.5 \mathrm{kyr}$ BP were also documented (Verleye et al., 2009). Filipova-Marinova et al. (2012) suggest increased fresh-water input and decrease of SSS in the western part of the Black Sea at $\sim 2570$ cal. BP, indicated by sporadic presence of Spiniferites cruciformis and Pediastrum. Mertens et 100 
al. (2012) also observed an decrease in SSS estimations derived from the process length of $L$. machaerophorum, at around 2.45 cal kyr BP. Additionally, the decrease in Black Sea SSSs after $3 \mathrm{kyr}$ BP is evidenced by lower $\square \mathrm{D}$ values of $\mathrm{C}_{37}$ alkenones produced by haptophyte algae (mainly Emiliania huxleyi) (van der Meer et al., 2008). All these records support the freshening event in the Black Sea basin at $\sim 2.5$ or $3 \mathrm{kyr}$ BP, underlining the complexity in SSS changes of the Black Sea during the late Holocene.

The dinocyst record 22-GC3 demonstrates changes in dinocyst assemblages, which cannot be explained by solely SSS changes. One of these is periodical changes of dominants in the assemblages: 1) Lingulodinium machaerophorum (maxima at 7-5.4, 3.7-2.5, 1.8-1 kyr BP) against 2) Spiniferites species and later together with heterotrophs (maxima at 8.3-7, 5.43.7, 2.5-1.8 and $1 \mathrm{kyr}$ BP to present) (Fig. 5a zones H2-H4). With regards to cyst production, Lingulodinium polyedrum needs stratified water column conditions in summer, therefore water turbulence is considered to be an inhibiting factor for Lingulodinium polyedrum growth as well as for its reproduction (Lewis and Hallett, 1997). On the other hand, high abundances of heterotrophic species, feeding on phytoplankton, indicate increased nutrient supply (Mudie et al., 2004). Verleye et al. (2009) discussed periodicity in changes in dominance (Lingulodinium machaerophorum against Spiniferites spp. and cyst of Pentapharsodinium dalei) for the dinocyst record GeoB 7625-2, where the abundance of Lingulodinium machaerophorum was correlated with the low clay layer frequency indicating reduced river input (Lamy et al., 2006) and rather calm water conditions (Verleye et al., 2009). In contrast, the high relative abundance of Spiniferites spp. and cyst of Pentapharsodinium dalei correlate with high river discharge (Verleye et al., 2009). In our record, cysts of Pentapharsodinium dalei occur in low frequencies, probably due to the offshore location of the core with less fluviatile influence. Because core $22-\mathrm{GC} 3$ is located $\sim 100 \mathrm{~km}$ off the coast, another possibility of increased nutrient supply could be taken into account e.g. increased upwelling or possible changes in eddy dynamics (Özsoy and Ünlüata, 1997). The fluctuations between Spiniferites spp. dominated assemblages and Lingulodinium machaerophorum at 6-7 kyr BP are known from dinocyst records in the western part of the Black Sea (e.g. Mudie et al., 2001; Atanassova, 2005; Marret et al., 2009; Verleye et al., 2009), indicating similarity of changes in the entire basin. 


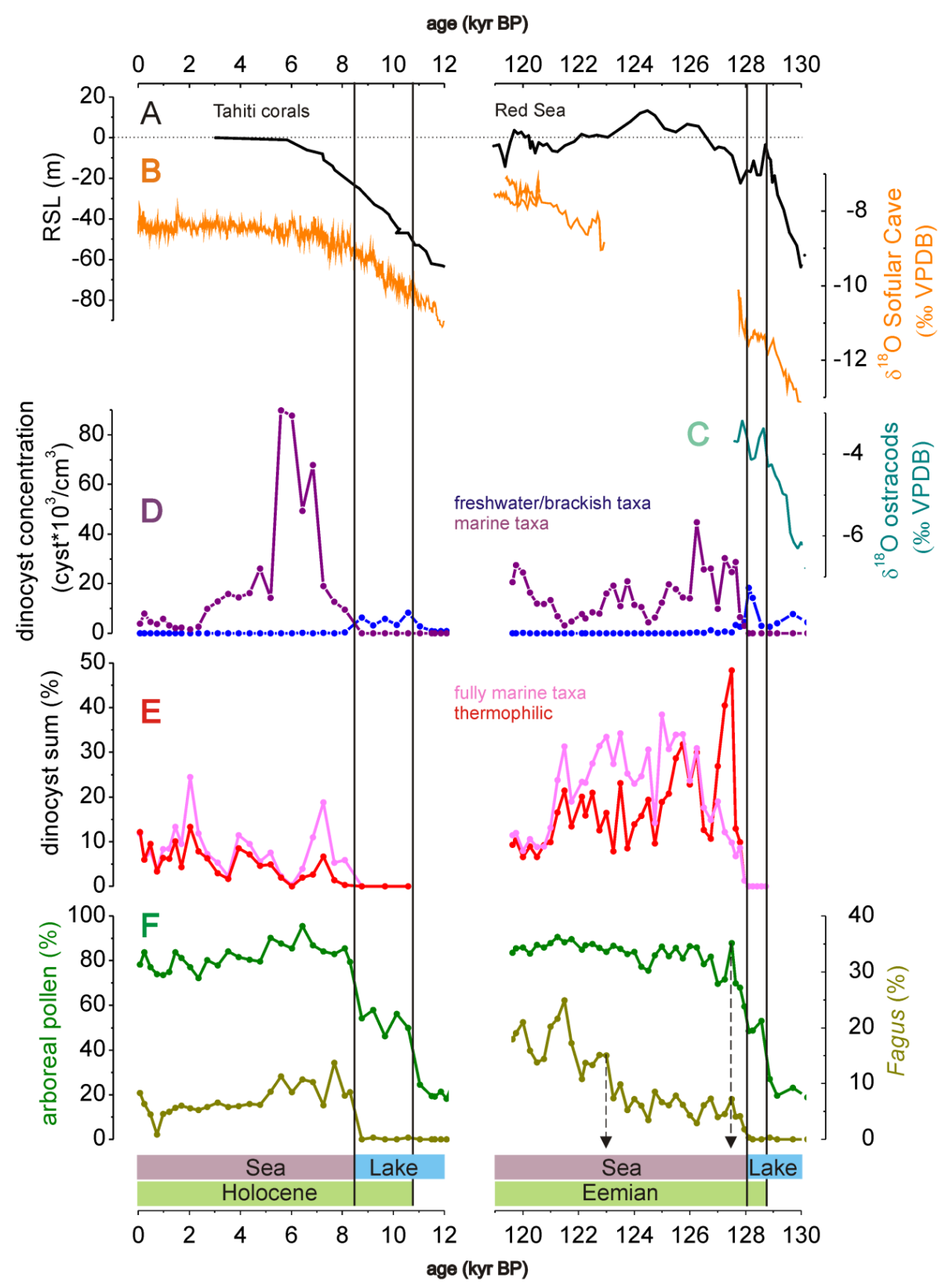

Fig. 6. Summary diagram of key proxies discussed in the text: (A) relative sea-level (m) for Holocene, obtained from Tahiti corals (Bard et al., 1996), and Eemian, obtained from the Red Sea record (Rohling et al., 2010), with a dashed line for zero sea-level; (B) $\delta^{18}$ O speleothem records (orange) from the Sofular Cave (Badertscher et al., 2011) demonstrate different glacial-interglacial amplitudes and together with $(\mathrm{C}) \delta^{18} \mathrm{O}$ ostracod record (light blue) from sediment core 22-GC3 (this study) indicate rapid change of isotopic composition during the glacial-Eemian transition; (D) dinocyst concentration of freshwater/brackish (dark blue) and marine (purple) taxa (this study) reflect lacustrine - marine transition; (E) percentage sums of thermophilic (red) and fully marine (rose) taxa (this study) used as indicators of SST and SSS, respectively; (F) arboreal pollen (green) and Fagus (yellowish green) percentages (Shumilovskikh et al., 2012 for Holocene, in prep. for Eemian), used for stratigraphical correlation in Eemian. Land - sea correlation is demonstrated by sea (purple rectangle) - lake (blue rectangle) conditions plotted against interglacial conditions (green rectangle). 
Other significant hydrological changes at $\sim 5.4 \mathrm{kyr}$ BP (H3a) are indicated by an increase in the relative abundance of peridinoid cysts, increase in dinocyst diversity and appearance of several new NPPs. Increases in the relative abundance of heterotrophs are also evident in high resolution records from the southwestern part of the Black Sea (Marret et al., 2009; Verleye et al., 2009) and could be explained by increased nutrient supply. Increase in diversity of peridinoid species in 22-GC3 record at $\sim 3$ kyr BP contrasts with the observations in the GeoB 7625 record, where most of peridinoid species appear shortly after $8.3 \mathrm{kyr}$ BP (Verleye et al., 2009). The most likely explanation for this difference is the close proximity of core GeoB 7625-2 to the Sakarya River, whereas core 22-GC3 is located $\sim 100 \mathrm{~km}$ away from the coast. This explanation could be an alternative to the merchant shipping hypothesis (Marret et al., 2009). Looking at the changes in heterotroph assemblages and in particular the increase of cysts of Gymnodinium catenatum / nolleri in MAR02-45 at $2.2 \mathrm{kyr}$ BP, Marret et al. (2009) consider an introduction of this species through the use of larger merchant ships for trading between the Mediterranean and Black Sea coast. However, the presence and relatively high abundance of Gymnodinium species in GeoB 7625-2 since as early as $8.3 \mathrm{kyr}$ BP (Verleye et al., 2009) support the increase in nutrients as a more plausible hypothesis.

\subsection{Change in the southern Black Sea sea-surface conditions during the Eemian}

Prior to the inflow of Mediterranean water into the Black Sea at around $128 \mathrm{kyr}$ BP, dinocyst assemblages were very similar to those observed during the early Holocene. They show little diversity and are dominated by three fresh/brackish species (Pyxidinopsis psilata, Spiniferites cruciformis, Caspidinium rugosum) (Fig. 5b), indicative of fresh/brackish water conditions between 7 and 12 psu. The high abundance of Caspidinium rugosum (40\%) before $128 \mathrm{kyr}$ BP is a strong evidence for a Caspian - Black Sea connection preceding the Mediterranean - Black Sea reconnection. The Caspean - Black Sea connection was already documented by foraminiferal, mollusc and ostracod records from Eltigen (zone 1) (Yanko et al., 1990), and was recently dated at $\sim 131-132 \mathrm{kyr}$ BP by a speleothem $\delta^{18} \mathrm{O}$ record from Northern Turkey (Fig. 6B) (Badertscher et al., 2011). The Caspian - Black Sea connection was caused by input of high amount of glacier melt water into both basins during the glacial transition period and occurred through Manych (Fig. 2) (Yanko et al., 1990; Badertscher et al., 2011).

The rise in global sea level during the glacial transition period and early Eemian (Fig. 6A) led to the intrusion of Mediterranean waters through the Bosphorus sill ( $37 \mathrm{~m} \mathrm{bpsl)} \mathrm{into}$ the Black Sea. This change is clearly indicated by a gradual decrease of fresh/brackish taxa 
and an abrupt rise of dinocyst concentrations and number of marine species such as Lingulodinium machaerophorum, Spiniferites mirabilis, Tuberculodinium vancampoae etc. at 128 kyr BP (LZ E2a; Fig. 5b, 6D). While the increase in dinocyst concentrations could be related to an increase in productivity due to rising temperature, the increase in the number of species is likely to be linked to the opening of the Mediterranean corridor and salinity change induced by an input of the saline Mediterranean waters.

The increase in Tuberculodinium vancampoae (LZ E2b; Fig. 5b), a species restricted to subtropical to tropical regions and currently absent in the Mediterranean Sea (Marret and Zonneveld, 2003), is interesting. Tuberculodinium vancampoae was first described (as Pterospermopsis Van Campoae; Rossignol 1962) from Plio-Pleistocene coastal depositions in the Eastern Mediterranean (Rossignol, 1962). This species is abundant in Mediterranean sapropels 3 and 4 from Crete (Versteegh, pers. comm.), and even present in marine sediments from the Marmara Sea during the warming period after the Last Glacial Maximum (Londeix et al., 2009). Therefore, we assign the occurrence of Tuberculodium vancampoae in core 22GC3 to be closely related to the Mediterranean corridor and set a date for the establishment of warm brackish/marine conditions in the Black Sea at $\sim 127.6 \mathrm{kyr}$ BP. The fact that Eemian dinocyst assemblages in core 22-GC3 (LZ E2b) around 127.6-126.9 kyr BP are dominated by Tuberculodinium vancampoae (14-40\%) suggests minimum SSTs of $7^{\circ} \mathrm{C}$ in winter (presently at $4-8^{\circ} \mathrm{C}$ ) and possibly up to $27^{\circ} \mathrm{C}$ in summer (presently at $23-25^{\circ} \mathrm{C}$ ) and SSS $>20$ (presently at 18) as well as possible oligotrophic conditions. These qualitative estimations are derived from its modern distribution (Marret and Zonneveld, 2003) as well as laboratory culture experiments with Pyrophacus steinii (motile stage of Tuberculodinium vancampoae) (Zonneveld and Susek, 2007). Occurrence of other thermophilic taxa such as Tectatodinium pellitum, Spiniferites bentorii, Spiniferites mirabilis, Spiniferites hyperacanthus (Marret and Zonneveld, 2003) during this time support the interpretation of warm conditions. Between 126.9-126.6 kyr BP, low percentages of these thermophilic taxa (5\%) possibly reveal a brief cold episode during this period (Fig. 5b, 6E).

After $\sim 126.6 \mathrm{kyr} \mathrm{BP}$, the dinocyst composition suggests a further rise in SSS and SST, indicated by an increase of indicators of warm and/or fully marine conditions such as Spiniferites pachydermus, Tectatodinium pellitum, cysts of Polykrikos schwartzii, cysts of Protoperidinium stellatum, Bitectatodinium tepikiense, Ataxiodinium choane, Spiniferites bentorii, and Spiniferites mirabilis (Fig. 5b). Based on the modern distribution of the rather abundant species Spiniferites pachydermus (2-20\%), hydrological conditions were most likely 

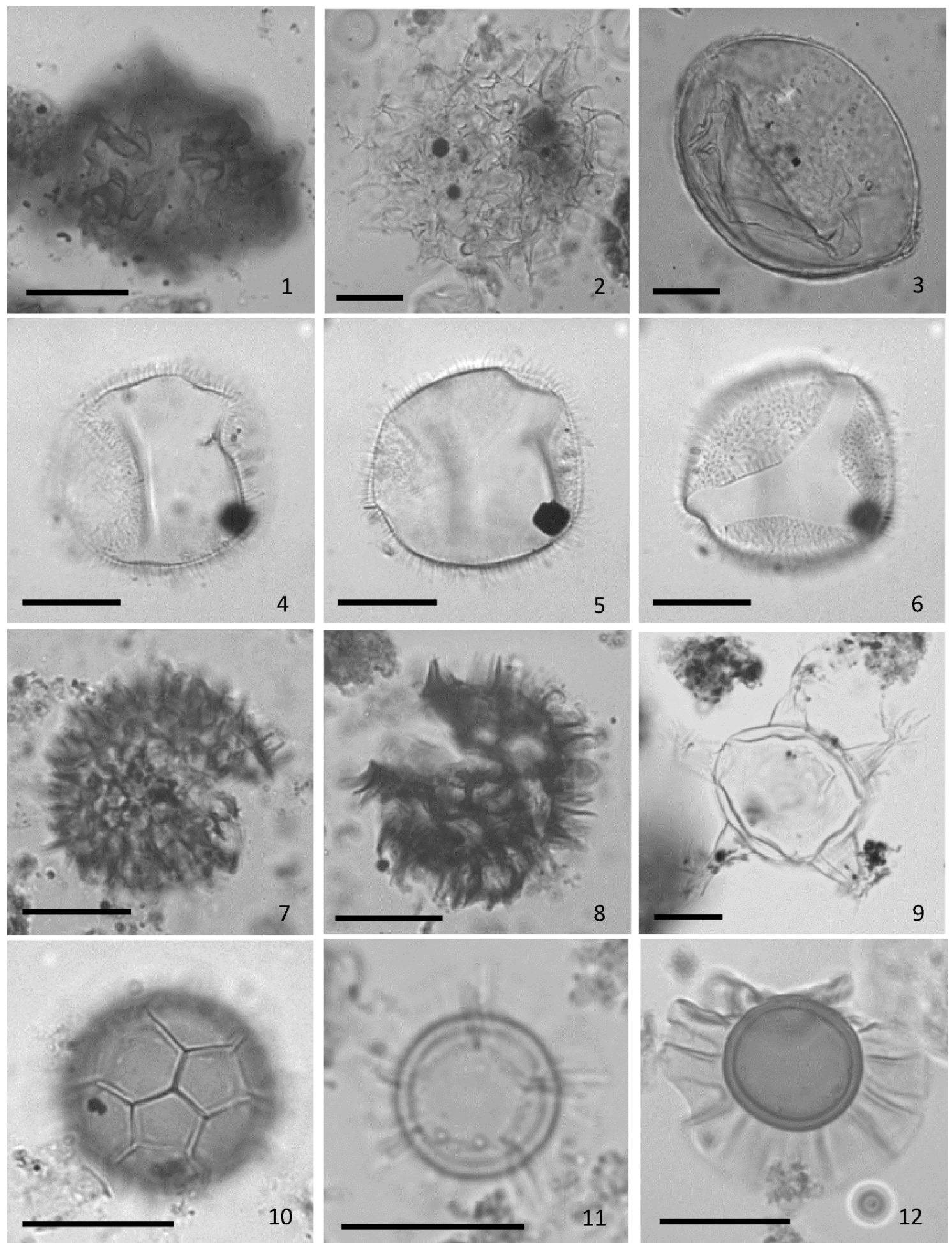

Plate 3. Light microscope photographs of selected dinocysts, algae and non-pollen palynomorphs from core 22-GC3, scale bar is $20 \mu \mathrm{m}: 1$ - cyst of Cochlodinium spec. $(2 \mathrm{~cm}$, high focus); 2 - Cobricosphaeridinium spiniferum ? (2 cm, optical section); 3 - Type BS3, animal egg? (16 cm; optical section); 4-6 - Type BS1 (52 cm, optical section (5), high (4) and low (6) focus) (possibly similar to Type B of Verleye et al. (2009)); 7 - Type BS2, core depth $20 \mathrm{~cm}$, combined foci; 8 - Type BS2, core depth $784 \mathrm{~cm}$, high focus; 9 - Hexasterias problematica $(0.5 \mathrm{~cm}$, optical section); 10 - Cymatiosphaera globulosa $(812 \mathrm{~cm}$, high focus); 11 - Cymatiosphaera sp. (793 cm, high focus); 12 - Pterospermella $(780.5 \mathrm{~cm}$; optical section) 
characterized by high SSTs (minimum $12{ }^{\circ} \mathrm{C}$ in winter and $29{ }^{\circ} \mathrm{C}$ in summer) and high SSS ( 30) (Marret and Zonneveld, 2003). In contrast to Spiniferites pachydermus (SST range between $12^{\circ} \mathrm{C}$ and $29^{\circ} \mathrm{C}$ ), Bitectatodinium tepikiense tolerates winter SSTs from around -2 to $17^{\circ} \mathrm{C}$ and summer SSTs from around -2 and $21^{\circ} \mathrm{C}$ (Marret and Zonneveld, 2003). Therefore, decrease of Spiniferites pachydermus and increase of Bitectatodinium tepikiense at $\sim 125.3 \mathrm{kyr}$ BP (LZ E3a/E3b; Fig. 5b) could be possibly related to a decrease in SST. Considering the ecological preferences of the dinocyst species in core 22-GC3, the interval between 126.6 and 121.1 kyr BP is the most saline period in the record, whereas the period $\sim 127.6-125.3 \mathrm{kyr} \mathrm{BP}$ stands out as the warmest period (Fig. 6E).

The considerable decrease in abundance of thermophilic and halophilic taxa since $\sim 123$ (LZ E3c) and their almost complete disappearance after $121 \mathrm{kyr}$ BP (LZ E4) reveal distinct reductions in SSS and SST at this time.

Similar to the Holocene, periodical shifts of the dominant taxa Lingulodinium machaerophorum and Spiniferites spp. occur during the Eemian (LZ E2/E3/E4; Fig. 5b). The dominance of the Spiniferites complex continued from 126.9 to $121.1 \mathrm{kyr}$ BP (E3), with a very low abundance of Lingulodinium machaerophorum ( 3-14 \%). Similar to during the Holocene, nutrient supply and turbid water conditions could be considered to be the most likely factors for the low occurrence of Lingulodinium machaerophorum. This is supported by the high abundance of Cymatiosphaera sp. (up to 183\%) during the Spiniferites-dominated period (E3). Martin (1993) associated the acritarch genus Cymatiosphaera sp. as encysted stage (called phycoma) of prasynophytes genus Pterosperma. Recently Mudie et al. (2011) suggest that it may be used as an indicator of the nutrient-rich conditions in the Black Sea.

5.3. Regional comparison of the Black Sea marine conditions during the Eemian and the Holocene

Core 22-GC3 provides the first detailed dinocyst record for the Eemian in the Black Sea. To interpret the fluctuations in our semi-quantitative SST and SSS reconstructions, we used existing Eemian records from the Black Sea region. These include marine sediment cores (e.g. core 379, 1136) and outcrops (e.g., the Eltigen outcrop) (Table 3). The Eltigen outcrop $\left(45^{\circ} 11^{\prime} \mathrm{N} 36^{\circ} 23^{\prime} \mathrm{E}\right)$ is located on the western coast of the Kerch Strait between Tobechikskoe Lake and the settlement of Geroevskoe (or Eltigen) (Fig. 1), and considered as the most detailed and continuous record for the Eemian stage of the Black Sea in Russian literature (e.g. Yanko et al., 1990). Eemian and Holocene assemblages of dinocysts, 
molluscs, foraminifers, coccoliths and diatoms and reconstructed palaeosalinity ranges are provided in Table 3.

Table 3. Characteristic species of dinocysts, benthic foraminifers, mollusks, diatoms and coccoliths assemblages after Mediterranean inflow into Black Sea basin in the Eemian and Holocene. After species list in brackets are SSS reconstructions given by authors.

\begin{tabular}{|c|c|c|c|c|c|}
\hline $\begin{array}{l}\text { Period / } \\
\text { Group } \\
\text { sediment } \\
\text { (reference) }\end{array}$ & $\begin{array}{l}\text { Dinocysts } \\
\text { marine core } \\
\text { (this study) }\end{array}$ & $\begin{array}{l}\text { Mollusks } \\
\text { Eltigen, Caspian - } \\
\text { Black Sea terraces } \\
\text { (Nevesskaya, 1974; } \\
\text { Yanko et al., 1990; } \\
\text { Svitoch, 2008; } \\
\text { Yanina, 2009) }\end{array}$ & $\begin{array}{l}\text { Benthic } \\
\text { foraminifers } \\
\text { marine core } 1136 \\
\text { (Yanko-Hombach, } \\
\text { 2007) and Eltigen } \\
\text { (Yanko et al., } \\
\text { 1990) }\end{array}$ & $\begin{array}{l}\text { Diatoms } \\
\text { marine cores } \\
\text { (Jousé and } \\
\text { Mukhina, 1978, } \\
\text { 1980) }\end{array}$ & $\begin{array}{l}\text { Coccoliths } \\
\text { marine cores } \\
\text { (Bukry, 1974; } \\
\text { Persival, 1978; } \\
\text { Shumenko and } \\
\text { Ushakova, 1980; } \\
\text { Giunta et al., 2007) }\end{array}$ \\
\hline Holocene & $\begin{array}{l}\text { Lingulodinium } \\
\text { machaerophorum, } \\
\text { Spiniferitus } \\
\text { ramosus group, } \\
\text { Peridinium } \\
\text { ponticum }(15-20)\end{array}$ & $\begin{array}{l}\text { Cerastoderma spp, } \\
\text { Chione gallina, } \\
\text { Mytilus } \\
\text { galloprovincialis, } \\
\text { Abra ovata, } \\
\text { Monodacna caspia, } \\
\text { Cardium edule, } \\
\text { Corbula } \\
\text { mediterranea } \\
\text { maeotica }(18-20)\end{array}$ & $\begin{array}{l}\text { Ammonia tepida, } \\
\text { Elphidium } \\
\text { ponticum, } \\
\text { Ammonia } \\
\text { compacta, Nonion } \\
\text { matagordanus, } \\
\text { Canalifera } \\
\text { parkerae (12-19) }\end{array}$ & $\begin{array}{l}\text { Chaetocerus } \\
\text { peruvianus, } \\
\text { Hemiaulus } \\
\text { hauckii, } \\
\text { Rhizosolenia } \\
\text { alata, } \\
\text { Thalassionema } \\
\text { nitzschioides, } \\
\text { Thalassiosira } \\
\text { subsalina, } \\
\text { Cyclotella caspia, } \\
\text { Rhizosolenia } \\
\text { setigera, } \\
\text { Rhizosolenia } \\
\text { calcar-avis etc. } \\
\text { (marine) }\end{array}$ & $\begin{array}{l}\text { Emiliania huxleyi, } \\
\text { Braarudosphaera } \\
\text { bigelowi, } \\
\text { Syracosphaera } \\
\text { pirus, } \\
\text { Syracosphaera } \\
\text { mediterranea, } \\
\text { Acanthoica } \\
\text { acanthos, } \\
\text { Discolithina spp. } \\
(>11-17)\end{array}$ \\
\hline Eemian & $\begin{array}{l}\text { Tuberculodinium } \\
\text { vancampoae, } \\
\text { Spiniferites } \\
\text { pachydermus, } \\
\text { Bitectatodinium } \\
\text { tepikiense, } \\
\text { Spiniferites } \\
\text { mirabilis, } \\
\text { Tectatodinium } \\
\text { pellitum (up to 30) }\end{array}$ & $\begin{array}{l}\text { Cardium } \\
\text { tuberculatum, Ensis } \\
\text { ensis, Paphia } \\
\text { senescens, } \\
\text { Cerastoderma } \\
\text { glaucum, Mytilaster } \\
\text { lineatus, Abra } \\
\text { ovata, Chione } \\
\text { gallina, Ostrea } \\
\text { edulis, Loripes } \\
\text { lacteus, Chlamys } \\
\text { glabra (up to 30) }\end{array}$ & $\begin{array}{l}\text { Massilina } \\
\text { inaequalis, } \\
\text { Ammonia } \\
\text { compacta, } \\
\text { Quinqueloculina } \\
\text { laevigata, } \\
\text { Quinqueloculina } \\
\text { bicornis, } \\
\text { Canalifera } \\
\text { nigarensis, } \\
\text { Canalifera } \\
\text { punctata }(28-30) \\
\end{array}$ & $\begin{array}{l}\text { Thalassiosira } \\
\text { oestrupii, } \\
\text { Thalassiosira } \\
\text { subsalina, } \\
\text { Cyclotella caspia, } \\
\text { Coscinodiscus } \\
\text { perforatus, } \\
\text { Coscinodiscus } \\
\text { janischii, } \\
\text { Thalassiosira } \\
\text { nitzschioide } \\
\text { (marine) }\end{array}$ & $\begin{array}{l}\text { Gephyrocapsa } \\
\text { oceanica ssp. } \\
\text { caribbeanica } \\
\text { (marine) }\end{array}$ \\
\hline
\end{tabular}

In contrast to the Holocene, Eemian assemblages of dinocysts, molluscs, foraminifers, coccoliths and diatoms consist of abundant Mediterranean flora or fauna (Table 3). Characteristic species for fully marine conditions for the Eemian mollusc assemblages consist of Cardium tuberculatum, Ensis ensis (e.g. Nevesskaya, 1974; Yanko et al., 1990; Svitoch, 2008; Yanina, 2009) and for the benthic foraminifers - Massilina inaequalis, Ammonia compacta, Quinqueloculina laevigata, Quinqueloculina bicornis, Canalifera nigarensis, Canalifera punctata (Yanko et al., 1990). Coccolith assemblages were dominated by the marine coccolith Gephyrocapsa oceanica ssp. caribbeanica (Persival, 1978; Shumenko and Ushakova, 1980). Regarding the diatom assemblages, the marine species Thalassiosira oestrupii (Jousé and Mukhina, 1978, 1980) is abundant during the Eemian, but absent in 
present-day populations in the Black Sea, although it has been documented in the Holocene records (Shimkus et al., 1973).

\subsection{The Eemian Black Sea in a supra-regional context}

Comparison of Holocene and Eemian assemblages reveals that SSS is an important barrier for the distribution of the fully marine species from the Mediterranean Sea into the Black Sea and highlights higher SSS during the Eemian. Eemian records from the Black Sea strongly suggest SSSs of 28-30 (Nevesskaya, 1974; Jousé and Mukhina, 1978, 1980; Yanko et al., 1990; Svitoch, 2008; Yanina, 2009; dinocysts record from core 22-GC3), which are considerably higher than modern SSS of 17-18. What could be the reasons for this?

The Black Sea SSS is a function of its hydrological balance (e.g. Özsoy and Ünlüata, 1997). Thereby freshwater input (precipitation, rivers) is a decreasing factor, whereas the Mediterranean inflow and evaporation - an increasing one. The marked difference between the Eemian and Holocene SSSs distinctly reflects different hydrological balances of the basin during these time frames. Higher Black Sea SSS during the Eemian could be caused by 1) increased Mediterranean inflow and/or 2) increased evaporation and/or 3) decreased freshwater input (precipitation vs. fluvial). In order to evaluate these factors for the Eemian we consider each of them in the global context.

Mediterranean inflow into the Black Sea depends on the global sea level and Bosphorus depth. The global sea level reconstructions for the Eemian reveal a higher $(\sim 6 \mathrm{~m})$ level than today (e.g. Orszag-Sperber et al., 2001; Lisiecki and Raymo, 2005; Svitoch, 2008; Kopp et al., 2009; Rohling et al., 2009) (Fig. 6A). The close agreement of reconstructed peak Eemian SSS and highest global sea level between $~ 126.5-121$ kyr BP (Fig. 6A, 6E) demonstrates that the high Eemian Black Sea SSS were most likely caused by a stronger inflow of Mediterranean water.

If precipitation and riverine input are difficult to estimate, evaporation can be easily calculated based on the temperatures. Global temperatures during the Eemian were $\sim 2 \mathrm{C}^{\circ}$ higher than today (Jouzel et al., 1987; Guiot et al., 1989). This has been validated for Europe by multiproxy reconstructions (e.g. Aalbersberg and Litt, 1998; Kukla et al., 2002). In accordance, the dinocyst record 22-GC3 reveals high relative abundance of thermophilic species especially between $\sim 127.6-125.3 \mathrm{kyr}$ BP (Fig. 6E), associated with higher air temperatures in summer at this time. Higher temperatures during the Eemian might increase evaporation from the Black Sea and therefore contribute to its higher than modern SSSs during the Eemian. Furthermore, our suggestion that hydrological budget of the Black Sea 
during the Eemian was different compared the Holocene is underlined by the higher glacialinterglacial amplitude of $\delta^{18} \mathrm{O}$ isotope values from the Sofular Cave (Fig. 6B). The latter together with ostracod-based $\delta^{18} \mathrm{O}$ isotopes from the Black Sea (Fig. 6C) indicates rapid change of oxygen isotope composition during the glacial/Eemian transition.

\section{Conclusions}

The present study on marine core 22-GC3 provides the first organic-walled dinoflagellate cyst record from the Black Sea for the Eemian in comparison to the Holocene section from the same sequence. The study highlights that the amount of Mediterranean inflow is very important to control sea-surface salinity in the Black Sea. Successions in the dinocyst assemblages clearly demonstrate the establishment of marine conditions in the Black Sea during the Eemian and Holocene, which occurred when the increasing global and Mediterranean Sea level reached the Bosphorus and flowed into the Black Sea basin. Eemian assemblages differ considerably from the Holocene ones with the presence of several fully marine species such as Spiniferites pachydermus, Spiniferites mirabilis, Bitectatodinium tepikiense, Tectatodinium pellitum, Nematosphaeropsis labyrinthus etc., indicating higher than present ( 18) SSS of $\sim 28-30$ at $\sim 126.5-121$ kyr BP. An increased Mediterranean supply triggered by a higher global sea level and higher temperatures at the beginning of the Eemian are likely to be the mechanism for such high SSS. Between $~ 127.6-125.3 \mathrm{kyr}$ BP, dinocyst assemblages dominated by Tuberculodinium vancampoae and Spiniferites pachydermus reveal relatively high SSTs $\left(7-12^{\circ}\right.$ in winter and $27-29^{\circ}$ in summer) in the Black Sea, confirming high temperatures at the beginning of Eemian. The Holocene dinocyst record demonstrates that SSS during this period never exceeded $\sim 18-20$ and reveal freshening of the basin at $2.5 \mathrm{kyr}$ BP. Changes in nutrient supply, in addition to changes in SSS and SST, are likely to have played a significant role in the successions of dinocyst assemblages during the Eemian and Holocene.

\section{Acknowledgements}

We thank Birgit Plessen, Helmholtz Centre Potsdam - German Research Centre for Geosciences (GFZ-Potsdam), for performing the stable isotope measurements on ostracods. We also thank Antje Wegwerth, Robert Kopp and Frank Schlütz for helpful discussions and comments on the manuscript and Laura Sutcliffe for polishing the English. We gratefully acknowledge the editor of "Marine Micropaleontology" Frans Jorissen as well as to Kenneth $\mathrm{N}$. Mertens and an anonymous reviewer for critical reading and improving the manuscript. 
Finally, we thank the captain and crew of RV METEOR for their support during the M72/5 Black Sea cruise in 2007. The work was funded by the German Research Foundation (BE 2116/20-1, AR 367/9-1, and FL 710/1-1) through the SPP 1266 INTERDYNAMIK, the GFZPotsdam and the Gary Comer Science and Education Foundation. Work on speleothems from Turkey was supported by the Swiss National Science Foundation (grant PP002-110554/1 to D.F.).

\section{References}

Aalbersberg, G., Litt, T., 1998. Multiproxy climate reconstructions for the Eemian and Early Weichselian. Journal of Quaternary Science 13, 367-390.

Allen and Huntley, 2009. Last Interglacial palaeovegetation, palaeoenvironments and chronology: a new record from Lago Grande di Monticchio, southern Italy. Quaternary Science Reviews 28, 1521 - 1538.

Atanassova, J., 2005. Palaeoecological setting of the western Black Sea area during the last 15 000 years. The Holocene 15, 576-584.

Badertscher, S., Fleitmann, D., Cheng, H., Edwards, R.L., Göktürk, O.M., Zumbühl, A., Leuenberger, M., Tüysüz, O., 2011. Pleistocene water intrusions from the Mediterranean and Caspian Seas into the Black Sea. Nature Geoscience, DOI: 10.1038/NGEO1106.

Bahr, A., Lamy, F., Arz, H.W., Kuhlmann, H., Wefer, G., 2005. Late glacial to Holocene climate and sedimentation history in the NW Black Sea. Marine Geology 214, 309-322.

Bahr, A., Arz, H.W., Lamy, F., Wefer, G., 2006. Late glacial to Holocene paleoenvironmental evolution of the Black Sea, reconstructed with stable oxygen isotope records obtained on ostracod shells. Earth and Planetary Science Letters 241, 863-875.

Bahr, A., Lamy, F., Arz, H.W., Major, C., Kwiecien, O., Wefer, G., 2008. Abrupt changes of temperature and water chemistry in the late Pleistocene and early Holocene Black Sea, Geochem. Geophys. Geosyst., 9, Q01004, doi:10.1029/2007GC001683.

Bard, E., Hamelin, B., Arnold, M., Montaggioni, L., Cabioch, G., Faure, G., Rougerie, F., 1996. Deglacial sea-level record from Tahiti corals and the timing of global meltwater discharge. Nature 382, 241-244.

Beşiktepe, Ş.T., Sur, H.I., Özsoy, E., Latıf, M.A., Oğuz, T., Ünlüata, Ü., 1994. The circulation and hydrography of the Marmara Sea. Progress in Oceanography 34, 285-334. 
Bukry, D., 1974. Coccoliths as Paleosalinity Indicators - Evidence from Black Sea. In: Degens, E.T., Ross, D.A. (Eds.), The Black Sea - geology, chemistry and biology. The American Association of Petroleum Geologists, Tulsa, USA, pp. 353-363.

Buynevich, I.V., Yanko-Hombach, V., Gilbert, A.S., Martin, R.E. (Eds.), 2011. Geology and Geoarchaeology of the Black Sea Region: beyond the flood hypothesis. The Geological Society of America, Boulder, USA.

Dale, B., 1996. Dinoflagellate cyst ecology: modelling and geological applications. In: Jansonius, J., McGregor, D.C. (Eds.), Palynology: principles and applications. Vol. 3. American Association of Stratigraphic Palynologists Foundation, pp. 1249-1275.

Debol'skaya, E.I., Yakushev, E.V., Kuznetsov, I.S., 2007. Estimating the Characteristics of the Vertical Turbulent Viscosity in the Upper 200-m Layer of the Black Sea. Oceanology 47 (4), 476-481.Filipova-Marinova, M., 2006. Late Pleistocene / Holocene dinoflagellate cyst assemblages from the Southwestern Black Sea shelf. In: OgnjanovaRumenova, N. and Manoylov, K. (Eds.), Advances in phycological studies. Pensoft Publishers \& University Publishing House, Sofia-Moscow, pp. 267-281.

Filipova-Marinova, M., Pavlov, D., Coolen, M., Giosan, L., 2012. First high-resolution marinopalynological stratigraphy of the Late Quaternary sediments from the central part of the Bulgarian Black Sea area. Quaternary International, doi:10.1016/j.quaint.2012.05.002.

Ginzburg, A.I., Kostianoy, A.G., Sheremet, N.A., 2008. Sea Surface Temperature Varability. In: Kostianoy, G., Kosarev, A.N. (Eds.), The Handbook of Environmental Chemistry: Vol.5, Part Q: The Black Sea Environment. Springer Verlag, Berlin - Heidelberg, pp. 255-275.

Giunta, S., Morigi, C., Negri, A., Guichard, F., Lericolais, G., 2007. Holocene biostratigraphy and Paleoenvironmental changes in the Black Sea based on calcareous nannoplankton. Marine Micropaleontology 63, 91-110.

Guiot, J., Pons, A., de Beaulieu, J.L., Reille, M., 1989. A 140,000-Year continental climate reconstruction from 2 European pollen records. Nature 338, 309-313.

Hay, B.J., Arthur, M.A., Dean, W.E., Neff, E.D., Honjo, S., 1991. Sediment deposition in the late Holocene abyssal Black Sea with climatic and chronological implications. Deep Sea Research, Part A, 38, suppl. 2, S1211-S1235.

Jones, G.A., Gagnon, A.R., 1994. Radiocarbon chronology of the Black Sea sediments. DeepSea Research Part I 41, 531-557. 
Jousé, A.P., Mukhina, V.V., 1978. Diatom units and the paleogeography of the Black Sea in the late Cenozoic (DSDP, Leg 42B). In: Ross, D.A., Neprochnov, Y.P. et al. (Eds.), Initial Reports of the Deep Sea Drilling Project. Volume 42, part 2, U.S. Government Printing Office, Washington, pp. 903-950.

Jousé, A.P., Mukhina, V.V., 1980. Paleogeografiya Chernogo moria po dannym izucheniya diatomei I sporovo-pyltsevogo analiza glubokovodnyh otlozheniy. In: Neprochnov, Yu.P. (Eds.), Geological History of the Black Sea: Results of Deep-Sea Drilling. Nauka, Moscow, pp. 52-65 (in Russian).

Jouzel, J., Lorius, C., Petit, J.R., Genthon, C., Barkov, N.I., Kotlyakov, V.M., Petrov, V.M, 1987. Vostok Ice Core - A continuous isotope temperature record over the last climatic cycle (160,000 Years). Nature 329, 403-408.Juggins, S., 2007. C2 Version 1.5. User guide. Software for ecological and palaeoecological data analysis and visualization. University of Newcastle, Newcastle upon Tyne.

Kopp, R.E., Simons, F.J., Mitrovica, J.X., Maloof, A.C., Oppenheimer, M., 2009. Probabilistic assessment of sea level during the last interglacial stage. Nature 462, 863868.

Kosarev, A.N., Kostianoy, A.G., 2008. Introduction. In: Kostianoy, G., Kosarev, A.N. (Eds.), The Handbook of Environmental Chemistry: Vol.5, Part Q: The Black Sea Environment. Springer Verlag, Berlin - Heidelberg, pp. 1-10.

Kosarev, A.N., Kostianoy, A.G., Shiganova, T.A., 2008. The Sea of Azov. In: Kostianoy, G., Kosarev, A.N. (Eds.), The Handbook of Environmental Chemistry: Vol.5, Part Q: The Black Sea Environment. Springer Verlag, Berlin - Heidelberg, pp.63-89.

Kukla, G.J., Bender, M.L., de Beaulieu, J.-L., Bond, G., Broecker, W.S., Cleveringa, P., Gavin, J.E., Herbert, T.D., Imbrie, J., Jouzel, J., Keigwin, L.D., Knudsen, K.-L., McManus, J.F., Merkt, J., Muhs, D.R., Müller, H., Poore, R.Z., Porter, S.C., Seret, G., Shackleton, N.J., Turner, C., Tzedakis, P.C., Winograd, I.J., 2002. Last Interglacial Climates. Quaternary Research 58, 2-13.

Kwiecien, O., Arz, H.W., Lamy, F., Wulf, S., Bahr, A., Röhl, U., Haug, G.H., 2008.

Estimated reservoir ages of the Black Sea since the Last Glacial. Radiocarbon 50 (1), 99-118.

Kwiecien, O., Arz, H.W., Lamy, F., Plessen, B., Bahr, A., Haug, G.H., 2009. North Atlantic control on precipitation pattern in the eastern Mediterranean / Black Sea region during the last glacial. Quaternary Research 71, 375-384. Lamy, F., Arz, H.W., Bond, G.C., Bahr, A., Pätzold, J., 2006. Multicentennial-scale hydrological changes in the Black Sea 
and northern Red Sea during the Holocene and the Arctic/North Atlantic Oscillation. Paleoceanography 21, PA1008, doi:10.1029/2005PA001184.

Lewis, J., Hallett, R., 1997. Lingulodinium polyedrum (Gonyaulax polyedra) a blooming dinoflagellate. Oceanography and Marine Biology: an Annual Review 35, 97-161.

Lisiecki, L.E., Raymo, M.E., 2005. A Pliocene-Pleistocene stack of 57 globally distributed benthic $\delta^{18}$ O records. Paleoceanography 20, PA1003, doi: 10.1029/2004PA001071.

Londeix, L., Herreyre, Y., Turon, J.-L., Fletscher, W., 2009. Last Glacial to Holocene hydrology of the Marmara Sea inferred from a dinoflagellate cyst record. Review of Palaeobotany and Palynology 158, 52-71.

Marret, F., Zonneveld, K.A.F., 2003. Atlas of modern organic-walled dinoflagellate cyst distribution. Review of Palaeobotany and palynology 125, 1-200.

Marret, F., Leroy, S., Chalié, F., Gasse, F., 2004. New organic-walled dinoflagellate cysts from recent sediments of Central Asian seas. Review of Palaeobotany and Palynology $129,1-20$.

Marret, F., Mudie, P., Aksu, A., Hiscott, R.N., 2009. A Holocene dinocyst record of a twostep transformation of the Neoeuxinian brackish water lake into the Black Sea. Quaternary International 197, 72-86.

Martin, F., 1993. Acritarchs: a review. Biological Reviews 68, 475-538.

Mertens, K.N., Bradley, L.R., Takano, Y., Mudie, P.J., Marret, F., Aksu, A.E., Hiscott, R.N., Verleye, T.J., Mousing, E.A., Smyrnova, L.L., Bagheri, S., Mansor, M., Pospelova, V., Matsuoka, K., 2012. Quantitative estimation of Holocene surface salinity variation in the Black Sea using dinoflagellate cyst process length. Quaternary Science Reviews, doi:10.1016/j.quascirev.2012.01.026.

Mikhailov, V.N., Mikhailova, M.V., 2008. River mouths. In: Kostianoy, G., Kosarev, A.N. (Eds.), The Handbook of Environmental Chemistry: Vol.5, Part Q: The Black Sea Environment. Springer Verlag, Berlin - Heidelberg, pp. 91-133.

Mudie, P.J., Aksu, A.E., Yasar, D., 2001. Late Quaternary dinoflagellate cysts from the Black, Marmara and Aegean seas: variations in assemblages, morphology and paleosalinity. Marine Micropaleontology 43, 155-178.

Mudie, P.J., Rochon, A., Aksu, A.E., Gillespie, H., 2002. Dinoflagellate cysts, freshwater algae and fungal spores as salinity indicators in Late Quaternary cores from Marmara and Black seas. Marine Geology 190: 203-231.

Mudie, P.J., Rochon, A., Aksu, A.E., Gillespie, H., 2004. Late glacial, Holocene and modern dinoflagellate cyst assemblages in the Aegean - Marmara - Black Sea corridor: 
statistical analysis and re-interpretation of the early Holocene Noah's Flood hypothesis. Review of Palaeobotany and Palynlogy 128, 143-167.

Mudie, P.J., Marret, F., Aksu, A.E., Hiscott, R.N., Gillespie, H., 2007. Palynological evidence for climatic change, anthropogenic activity and outflow of Black Sea water during the late Pleistocene and Holocene: Centennial- to decadal-scale records from the Black and Marmara Seas. Quaternary International 167-168, 73-90.

Mudie, P.J., Leroy, S.A.G., Marret, F., Gerasimenko, N.P., Kholeif, S.E.A., Sapelko, T., Filipova-Marinova, M., 2011. Nonpollen palynomorphs: indicators of salinity and environmental change in the Caspean - Black Sea - Mediterranean corridor. In: Buynevich, I.V., Yanko-Hombach, V., Gilbert, A.S., Martin, R.E. (Eds.) Geology and Geoarcheology of the Black Sea region: Beyond the flood hypothesis. The Geological Society of America, Colorado, pp. 89-115.

Murray, J.W., Fuchsman, C., Kirkpatrick, J., Paul, B., Konovalov, S.K., 2005. Species and $\delta^{15} \mathrm{~N}$ Signatures of nitrogen transformations in the Suboxic Zone of $\mathrm{t}$ he Black Sea. Oceanography 18, 36-47.

Nevesskaya, L.A., 1974. Molluscan Shells in Deep-Water Sediments of Black Sea. In: Degens, E.T., Ross, D.A. (Eds.), The Black Sea - geology, chemistry and biology. The American Association of Petroleum Geologists, Tulsa, USA, pp. 349-352.

Nezlin, N.P., 2008. Seasonal and Interannual Variability of Remotely Sensed Chlorophyll. In: Kostianoy, G., Kosarev, A.N. (Eds.), The Handbook of Environmental Chemistry: Vol.5, Part Q: The Black Sea Environment. Springer Verlag, Berlin - Heidelberg, pp. 333-349.

Oguz, T., Latun, V.S., Latif, M.A., Vladimirov, V.V., Sur, H.I., Markov, A.A., Özsoy, E., Kotovshchikov, B.B., Eremeev, V.V., Ünlüata, Ü., 1993. Circulation in the surface and intermediate layers of the Black Sea. Deep-Sea Research 40, 1597-1612.

Orszag-Sperber, F., Plaziat, J.-C., Baltzer, F., Purser, B.H., 2001. Gypsum salina - coral reef relationships during the Last Interglacial (Marine Isotope Stage 5e) on the Egyptian Red Sea coast: a Quaternary analogue for Neogene marginal evaporites? Sedimentary Geology 140, 61-85.

Özsoy, E., Ünlüata, Ü., 1997. Oceanography of the Black Sea: a review of some recent results. Earth-Science Reviews 42, 231-272.

Percival, S.F., 1978. Indigenous and reworked coccoliths from the Black Sea. In: Ross, D.A., Neprochnov, Y.P. et al. (Eds.), Initial Reports of the Deep Sea Drilling Project. Volume 42, part 2, U.S. Government Printing Office, Washington, pp. 773-781. 
Rochon, A., Vernal, A. de, Turon, J.-L., Matthiessen, J., Head, M.J., 1999. Distribution of recent dinoflagellate cysts in surface sediments from the north Atlantic ocean and adjacent seas in relation to sea-surface parameters. AASP Contributions Series 35, 7-59.

Rohling, E.J., Grant, K., Bolshaw, M., Roberts, A.P., Siddall, M., Hemleben, Ch., Kucera, M., 2009. Antarctic temperature and global sea level closely coupled over the past five glacial cycles. Nature Geoscience 2, 500-504.

Rohling, E.J., Braun, K., Grant, K., Kucera, M., Roberts, A.P., Siddall, M., Trommer, G., 2010. Comparison between Holocene and Marine Isotope Stage-11 sea-level histories. Earth and Planetary Science Letters 291, 97-105.

Ross, D., Degens, E.T., 1974. Recent sediments of Black Sea. In: Degens, E.T., Ross, D. (Eds.) The Black Sea - Geology, Chemistry and Biology. American Association of Petroleum Geologists, Tulsa, USA, pp. 183-199.

Ross, D.A., Neprochnov, Y.P. et al. (Eds.), 1978. Initial Reports of the Deep Sea Drilling Project. Volume 42, part 2, U.S. Government Printing Office, Washington.

Rossignol, M., 1962. Analyse pollinique de sediments marins Quaternaires en Israël. II. Sédiments Pleistocènes. Pollen et Spores 4 (1), 121-149.

Ryan, W.B.F., Pitman, III, W.C., 1998. Noah's Flood: The New Scientific Discoveries about Events that Changed History. Simion and Schuster, New York.

Shimkus, K.M., Mukhina, V.V., Trimonis, E.S., 1973. O roli diatomei v pozdnechetvertichnom osadkoobrazovanii Chernogo moria. Okeanologiya 13 (6), 10661071 (in Russian).

Shumenko, S.I., Ushakova, M.G., 1980. Izvestkovye nanofossilii v kernah glubokovodnogo bureniya. In: Neprochnov, Yu.P. (Eds.), Geological History of the Black Sea: Results of Deep-Sea Drilling. Nauka, Moscow, pp. $71-73$ (in Russian).

Shumilovskikh, L.S., Tarasov, P., Arz, H., Fleitmann, D., Marret, F., Nowaczyk, N., Plessen, B., Schlütz, F., Behling, H., 2012. Vegetation and environmental dynamics in the southern Black Sea region since $18 \mathrm{kyr}$ BP derived from the marine core 22-GC3. Palaeogeography, Palaeoclimatology, Palaeoecology 337-338, 177-193.

Stel'makh, L.V., Babich, I.I., Tugrul, S., Moncheva, S., Stefanova, K., 2009. Phytoplankton growth rate and zooplankton grazing in the Western part of the Black Sea in the autumn period. Oceanology 49 (1), 83-92. Svitoch, A.A., 2008. Quaternary Paleogeography of the Azov-Black Sea Basin. In: Kostianoy, G., Kosarev, A.N. (Eds.), The Handbook of Environmental Chemistry: Vol.5, Part Q: The Black Sea Environment. Springer Verlag, Berlin - Heidelberg, pp. 31-46. 
Tuzhilkin, V.S., 2008. Thermohaline Structure of the Sea. In: Kostianoy, G., Kosarev, A.N. (Eds.), The Handbook of Environmental Chemistry: Vol.5, Part Q: The Black Sea Environment. Springer Verlag, Berlin - Heidelberg, pp. 217-253.

Tzedakis, P.C., Frogley, M.R., Heaton, T.H.E., 2003. Last Interglacial conditions in southern Europe: evidence from Ioannina, northwest Greece. Global and Planetary Change 36, 157-170.

Uçkaç, Ş., 2005. Sea surface variability in the Aegean Sea. E.U. Journal of Fisheries \& Aquatic Sciences 22, 129-135.

Van der Meer, M.T.J., Sangiorgi, F., Baas, M., Brinkhuis, H., Damsté, J.S.S., Schouten, S., 2008. Molecular isotopic and dinoflagellate evidence for Late Holocene freshning of the Black Sea. Earth and Planetary Science Letters 267, 426-434.

Verleye, T.J., Mertens, K.N., Louwye, S., Arz, H.W., 2009. Holocene salinity changes in the southwestern Black Sea: a reconstruction based on dinoflagellate cysts. Palynology 33, 77-100.

Wall, D., Dale, B., 1974. Dinoflagellates in Late Quaternary deep-water sediments from the Black Sea. In: Degens, E.T. and Ross, D.A. (Eds.), The Black Sea: Its geology, chemistry and biology. American Association of Petroleum Geologists, pp. 364-380.

Wall, D., Dale, B., Harada, K., 1973. Descriptions of new fossil dinoflagellates from the Late Quaternary of the Black Sea. Micropaleontology 19, 18-31.

Yanina, T.A., 2009. Paleogeografiya basseynov Ponto-Kaspiya v Pleistocene po resultatam malakofaunisticheskogo analiza. Summary of Habil.-Thesis, Moscow State University, Russia (in Russian).

Yanko, V.V., Frolov, V.T., Motnenko, I.V., 1990. Foraminifery i litografiya stratotipicheskogo razreza Karangatskogo gorizonta (Antropogen Kerchenskogo poluostrova). Byulleten Moskovskogo Obshchestva ispytatelei prirody, Otdel Geology 65, 83-97 (in Russian, with English abstract).

Yanko-Hombach, V.V., 2007. Controversy over Noah's Flood in the Black Sea: geological and foraminiferal evidence from the shelf. In: Yanko, V.V., Gilbert, A.S., Panin, N., Dolukhanov, P.M. (Eds.), The Black Sea Flood Question: Changes in Coastline, Climate and Human Settlement. Springer, Dordrecht, pp.149-203.

Yanko-Hombach, V.V., Gilbert, A.S., Panin, N., Dolukhanov, P.M. (Eds.), 2007. The Black Sea Flood Question: Changes in Coastline, Climate and Human Settlement. Springer, Dordrecht. 
Yayla, M., Yilmaz, A., Morkoc, E., 2001. The dynamics of nutrient enrichment and primary production related to recent changes in the ecosystem of the Black Sea. Aquatic Ecosystem Health and Management 4 (1), 33-49.

Yu, S.-Y., Berglund, B.E., 2007. A dinoflagellate cyst record of Holocene climate and hydrological changes along the southeastern Swedish Baltic coast. Quaternary Research $67,215-224$

Yunev, O.A., Vedernikov, V.I., Basturk, O., Yilmaz, A., Kideys, A.E., Moncheva, S., Konovalov, S.K., 2002. Long-term variations of surface chlorophyll $a$ and primary production in the open Black Sea. Marine Ecology Progress Series 230, 11-28.

Yunev, O.A., Moncheva, S., Carstensen, J., 2005. Long-term variability of vertical chlorophyll a and nitrate profiles in the open Black Sea: eutrophication and climate change. Marine Ecology Progress Series 294, 95-107.

Zatsepin, A.G, Golenko, N.N., Korzh, A.O., Kremenetskii, V.V., Paka, V.T., Poyarkov, S.G., Stunzhas, P.A., 2007. Influence of the dynamics of currents on the hydrophysical structure of the waters and the vertical exchange in the active layer of the Black Sea. Oceanology 47 (3), 301-312.

Zonneveld, K.A.F., Susek, E., 2007. Effects of temperature, light and salinity on cyst production and morphology of Tuberculodinium vancampoae (the resting cyst of Pyrophacus steinii). Review of Palaeobotany and Palynology 145, 77-88. 


\title{
MANUSCRIPT 3
}

\section{Vegetation and environmental changes in Northern Anatolia between 134-119 ka recorded in Black Sea sediments}

\author{
Lyudmila S. Shumilovskikh ${ }^{\mathrm{a},{ }^{*}}$, Helge W. Arz ${ }^{\mathrm{b}}$, Antje Wegwerth ${ }^{\mathrm{b}}$, Dominik Fleitmann ${ }^{\mathrm{c}, \mathrm{d}}$, \\ Fabienne Marret ${ }^{\mathrm{e}}$, Norbert Nowaczyk ${ }^{\mathrm{f}}$, Pavel Tarasov ${ }^{\mathrm{g}}$, Hermann Behling ${ }^{\mathrm{a}}$
}

a Department of Palynology and Climate Dynamics, University of Göttingen, Untere Karspüle 2, 37073 Göttingen, Germany

b Leibniz Institute for Baltic Sea Research Warnemuende, Seestrasse 15, 18119 Rostock-

Warnemuende, Germany

c Department of Archaeology, School of Human and Environmental Sciences, University of Reading, Whiteknights, PO Box 227,Reading RG6 6AB, United Kingdom.

$\mathrm{d}$ Institute of Geological Sciences and Oeschger Centre for Climate Change Research, University of Bern, Baltzerstrasse 3, 3012 Bern, Switzerland

e School of Environmental Sciences, University of Liverpool, Liverpool, L69 7ZT, UK

f Helmholtz Center Potsdam GFZ German Research Centre for Geosciences, Telegrafenberg, 14473 Potsdam, Germany

$\mathrm{g}$ Institute of Geological Sciences, Palaeontology Department, Freie University Berlin, Malteserstr. 74-100, House D, Berlin, 12249, Germany

Quaternary Research, accepted on 25.07.2013

doi: 10.1016/j.yqres.2013.07.005 


\begin{abstract}
This multiproxy study on SE Black Sea sediments provides the first detailed reconstruction of vegetation and environmental history of Northern Anatolia between 134-119 ka. Here the glacial-interglacial transition is characterized by several short-lived alternating cold and warm events preceding a melt-water pulse ( 130.4-131.7 ka). The latter is reconstructed as a cold arid period correlated to the Heinrich event 11. The initial warming is evidenced at $\sim 130.4 \mathrm{ka}$ by increased primary productivity in the Black Sea, disappearance of ice-rafted detritus, and spreading of oaks in Anatolia. A Younger Dryas-type event is not identifiable. The Eemian vegetation succession corresponds to the main climatic phases in Europe: i) the Quercus-Juniperus phase (128.7-126.4 ka) indicates a dry continental climate; ii) the Ostrya-Corylus-Quercus-Carpinus phase (126.4-122.9 ka) suggests warm summers, mild winters, and high year-around precipitation; iii) the Fagus-Carpinus phase (122.9-119.5 ka) indicates cooling and high precipitation; iv) increasing Pinus at $\sim 121$ ka marks the onset of cooler/drier conditions. Generally, pollen reconstructions suggest altitudinal/latitudinal migrations of vegetation belts in Northern Anatolia during the Eemian caused by increased transport of moisture. The evidence for the wide distribution of Fagus around the Black Sea contrasts with the European records and is likely related to climatic and genetic factors.
\end{abstract}

Key words: pollen, dinoflagellate cysts, Fagus, vegetation history, palaeoclimate, Black Sea, penultimate glacial, MIS 5e, Eemian 


\section{Introduction}

The last interglacial (LI, or marine isotope stage (MIS) 5e, or Eemian) vegetation history in Western Europe is relatively well studied and shows evidence for a uniform succession of vegetation across the region (e.g. Aalbersberg and Litt, 1998; Sánchez Goñi et al., 1999; Tzedakis, 2000; Klotz et al., 2003; Sánchez Goñi et al., 2005). Major changes in vegetation occurred during MIS 5e and 5d in Europe in tandem with major climatic events, associated with changes in North Atlantic currents and meridional sea-surface temperature (SST) gradients (Müller and Kukla, 2004). The lack of detailed pollen records for the Eemian interval east of $30^{\circ} \mathrm{E}$ (e.g. Urmia Lake in Iran (Djamali et al., 2008); Fig. 1) hinders correlations with the North Atlantic region, and both vegetation and climate history remains unclear for this period. Pollen and sedimentary records from and around the Black Sea basin can provide valuable information to contribute towards our understanding of the vegetation and climate history of the area.

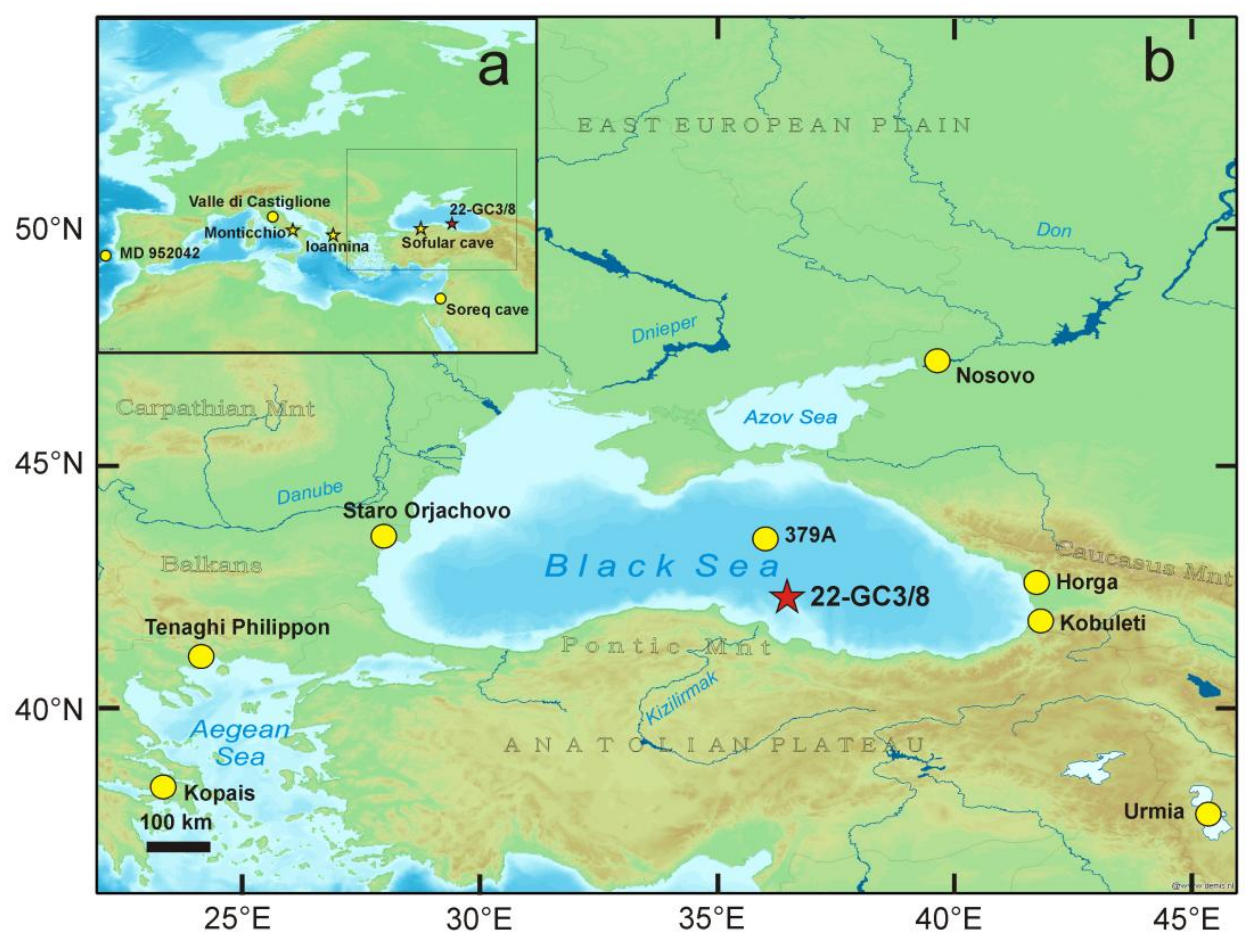

Fig. 1. Location map of the study region: a) map of Europe with locations of core 22-GC3/8 (red star) and cores used for age-model construction (yellow stars) and supra-regional comparison (yellow circles); b) geographical map of the Black Sea region with location of core 22-GC3/8 (red star) and other regional pollen records, referenced and discussed in the text (yellow circles). See PDF-file for colours. Map was drawn with Quantum GIS (1.7.0) using data from www.bgr.de, www.nowcoast.noaa.gov, www2.demis.nl.

Most palaeoenvironmental studies on sediments from the Black Sea have been carried out for the late-glacial and the Holocene periods (Lamy et al., 2006; Yanko-Hombach et al., 
2007; Bahr et al., 2008; Kwiecien et al., 2009; Filipova-Marinova et al., 2012; Shumilovskikh et al., 2012). Older sediments, covering the Quaternary and Pliocene intervals, were collected from the Black Sea during the R/V Glomar Challenger cruise in 1975 and studied at coarse resolution (Ross et al., 1978; Neprochov, 1980). These studies revealed that glacialinterglacial cycles were characterized by changes between steppe and forest on adjacent land and conditions between lacustrine and marine in the Black Sea. Some details on the Eemian vegetation were provided by pollen records from the Black Sea cores (Koreneva and Kartashova, 1978) and terrestrial sediments from Bulgaria (Božilova and Djankova, 1976), Russia (Spiridonova, 1991) and Georgia (Shatilova, 1974) (Fig. 1, Table 1). These records reveal the presence of tree species such as Fagus, Carpinus, Ostrya, Corylus, Quercus, Castanea, Pinus, and Picea in the surrounding region. However, the low temporal resolution of the records and the absence of robust chronologies prevent a detailed reconstruction of the LI vegetation changes in the Black Sea region.

Table 1. Site information for Eemian records discussed in the study.

\begin{tabular}{llllll}
\hline Site & Lat, N & Long, E & Alt, m & Material & Reference \\
\hline 379A & $43^{\circ} 00.29^{\prime}$ & $36^{\circ} 00.68^{\prime}$ & -2173 & marine & Koreneva and Kartashova, 1978 \\
Staro Orjachovo* & $43^{\circ} 00^{\prime}$ & $27^{\circ} 48^{\prime}$ & 50 & lake/river & Božilova and Djankova, 1976 \\
Nosovo-1* & $47^{\circ} 18^{\prime}$ & $39^{\circ} 18^{\prime}$ & 6 & paleosol & Spiridonova, 1991 \\
Horga* & $42^{\circ} 00^{\prime}$ & $41^{\circ} 50^{\prime}$ & 8 & terrestrial & Shatilova, 1974 \\
Kobuleti* & $41^{\circ} 49^{\prime}$ & $41^{\circ} 46^{\prime}$ & 7 & terrestrial & Shatilova, 1974 \\
Urmia & $37^{\circ} 32^{\prime}$ & $45^{\circ} 05^{\prime}$ & 1315.9 & lake & Djamali et al., 2008 \\
Tenaghi Philippon & $41^{\circ} 10^{\prime}$ & $24^{\circ} 20^{\prime}$ & 40 & peat & Wijmstra, 1969 \\
Kopais & $38^{\circ} 26.27^{\prime}$ & $23^{\circ} 03.02^{\prime}$ & 92.4 & lake & Tzedakis, 1999 \\
Sofular & $41^{\circ} 25^{\prime}$ & $31^{\circ} 56^{\prime}$ & 500 & speleothems & Badertscher et al., 2011 \\
Ioannina-284 & $39^{\circ} 45^{\prime}$, & $20^{\circ} 51^{\prime}$, & 473 & lake & Tzedakis et al., 2003 \\
Monticchio & $40^{\circ} 56^{\prime} 40^{\prime}$, & $15^{\circ} 36^{\prime} 30^{\prime}$, & 656 & lake & Allen and Huntley, 2009 \\
Valle di Castiglione & $41^{\circ} 53^{\prime} 30^{\prime}$, & $12^{\circ} 45^{\prime} 35^{\prime}$, & 44 & lake & Follieri et al., 1989 \\
MD952042 & $37^{\circ} 48^{\prime}$ & $10^{\circ} 10^{\prime}$ & -3148 & marine & Sánchez Goñi et al., 1999
\end{tabular}

Footnote: *-geographical coordinates of sites are not reported in the original publication and were georeferenced using gazetteers.

Vegetation changes and environmental conditions during the transition from the penultimate glacial to the Eemian and the onset of interglacial conditions for the Black Sea region have so far never been studied in detail. In general, the climate dynamics during the penultimate deglaciation remain obscure. For example, a number of pollen records demonstrate a Younger Dryas-type cooling event (Kattegat stadial) in Europe during the onset of the initial warming (Zeifen interstadial) (Seidenkrantz et al., 1996; Sánchez Goñi et al., 1999; Tzedakis, 2000; Sánchez Goñi et al., 2005), whereas other records do not support this cooling episode (Turner, 2000; Brauer et al., 2007; Allen and Huntley, 2009).

Here we present the first detailed pollen record based on sediment core 22-GC3/8 from the SE Black Sea (Fig. 1) covering 134-119 ka, which was used for the reconstruction of 
vegetation and climate changes in Northern Anatolia during this interval. The assumed pollen source area for 22-GC3/8 include the coastal areas nearest to the coring site, namely central part of Northern Anatolia and especially northern slopes of the Pontic Mountains (Shumilovskikh et al., 2012). The study also provides a comparison between pollen records from the Black Sea region and SW Europe. By using additional multi-proxy data from the same sediment core (ostracod-based $\delta^{18} \mathrm{O}$, dinoflagellate cysts (dinocysts), total inorganic carbonate (TIC), and ice-rafted detritus (IRD) records) we provide further insights into the environmental conditions in the SE Black Sea/Northern Anatolia during the penultimate deglaciation and the LI.

\section{Regional setting}

The Black Sea is the largest anoxic basin on Earth. The upper water layer (100-150 m) receives freshwater from rivers and atmospheric precipitation and is, therefore, cooler and less salty $(\sim 18 \%$ o) than the deeper waters $(\sim 22 \%$ ) , originating from the Mediterranean Sea (Özsoy and Ünlüata, 1997; Kostianoy and Kosarev, 2008). As a result of the strong stratification, only the upper $150 \mathrm{~m}$ of surface water layer is oxygenated and has a high biological productivity, whilst deeper water masses are anoxic. The general circulation pattern of the upper layer is characterized by a cyclonic main current with eastern and western gyres in the central part of the Black Sea and a number of anticyclonic eddies along the periphery (Oguz et al., 1993; Özsoy and Ünlüata, 1997; Kostianoy and Kosarev, 2008).

The regional climate of the Black Sea is controlled by seasonal changes in the position and strength of the Azores High and Icelandic Low influencing the westerly storm tracks (Türkeş, 1996). During summer, the Mediterranean high-pressure zone provides warm and dry air conditions for the entire Black Sea region with mean July temperatures $>20^{\circ} \mathrm{C}$ in the coastal areas. During winter, generally cold weather is caused by cold air masses from continental Asia with mean January temperatures around $0^{\circ} \mathrm{C}$ at low elevations. The northwest oriented slopes of the Pontic Mountains and Caucasus may receive up to 1000-2500 mm/yr (Alpat'ev et al., 1976; Mayer and Aksoy, 1986).

Local topography plays a determining role for the pattern of natural vegetation in the Black Sea area. A vegetation map for the entire Black Sea region (after Gerasimov, 1964) and corresponding biomes is provided in Shumilovskikh et al. (2012). Here, we briefly characterise the vegetation of the Pontic Mountains (Kürschner et al., 1997; Fig. 2). The wetter northern and western slopes of up to $\sim 800 \mathrm{~m}$ above sea level (asl) are covered by euxinian mixed forests with cool (Carpinus betulus, Fagus orientalis, deciduous Quercus, 
Corylus, Tilia) and warm (Castanea sativa, Carpinus orientalis, Ostrya carpinifolia) temperate deciduous trees, evergreen shrubs (Rhododendron ponticum, Prunus laurocerasus, Buxus sempervierens, Ilex colchica) and lianas (Hedera, Smilax, Tamus, Vitis, Periploca). Characteristic species of the Mediterranean macchia, such as Laurus nobilis, Arbutus andrachne, Erica arborea, Phillyrea latifolia, Quercus coccifera, grow in dry habitats on carbonates along the Black Sea coast (Zohary, 1973; Mayer and Aksoy, 1986). At elevations of $\sim 800-1500 \mathrm{~m}$ asl, beech (Fagus orientalis) or hornbeam-beech (Carpinus betulus-Fagus orientalis) forests predominate, whereas areas at altitudes above $\sim 1500 \mathrm{~m}$ are occupied by firs (Abies nordmanniana) in western and spruce (Picea orientalis) in eastern Pontic Mountains. The subalpine and alpine belt above $\sim 2000 \mathrm{~m}$ asl is dominated by grasslands with Juniperus communis. The south-east mountain slopes facing the Anatolian Plateau are covered by drier vegetation types, including open woodlands dominated by junipers (Juniperus excelsa, J. oxycedrus) and deciduous oaks (Quercus pubescens, $Q$. trojana), growing at the border between forest and steppe. In contrast, pines (Pinus nigra, P. sylvestris) together with Betula and Populus form the high-altitude forest line at $\sim 2000 \mathrm{~m}$. Above this elevation and in dry central regions of Anatolia, grasslands with thorny shrubs such as Astracanthus, Acantholimon, Sarcopoterium are characteristic.

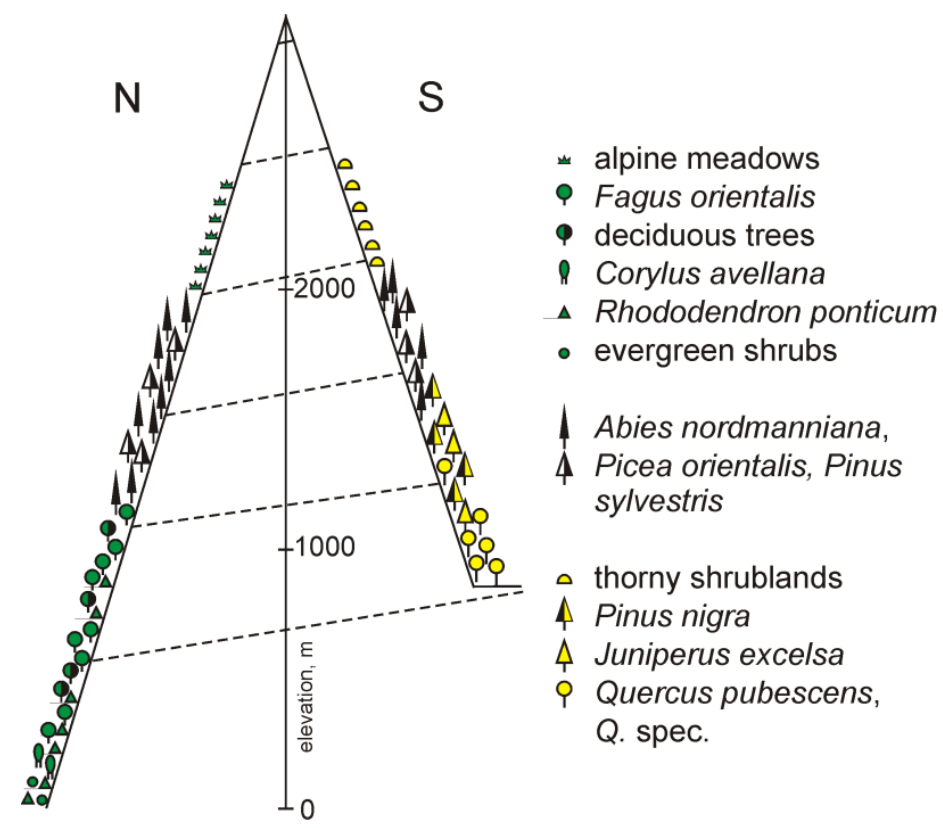

Fig. 2. Simplified vegetation profile across the Pontic Mountains (modified from Kürschner et al., 1997; details in Shumilovskikh et al., 2012). 


\section{Material and methods}

\section{Age-depth model}

Sediment cores 22-GC3 $(839 \mathrm{~cm})$ and 22-GC8 $(943 \mathrm{~cm})$ were taken during the RV METEOR cruise M72/5 in 2007 from the slope of the Archangelsky Ridge in the southeastern Black Sea $\left(42^{\circ} 13.53^{\prime} \mathrm{N} / 36^{\circ} 29.55^{\prime} \mathrm{E}, 838 \mathrm{~m}\right.$ water depth) (Fig. 1). Details on the construction of the composite depth from both cores and the age-depth model were recently published (see Shumilovskikh et al. (2013) for further details) and are presented in Figs 3 and 4 , and in Table 2. The cores were aligned by correlating the onset of the Eemian sapropel at $820.5 \mathrm{~cm}$ in core 22-GC3 (Fig. 3) and $809.5 \mathrm{~cm}$ in core 22-GC8 using visual core inspection as well as magnetic susceptibility and XRF logger data. The chronology for the penultimate glacial transition and the beginning of the Eemian in core 22-GC3/8 is based on the correlation of its $\delta^{18} \mathrm{O}$ ostracod record with the ${ }^{230} \mathrm{Th}$ dated speleothem $\delta^{18} \mathrm{O}$ record from Sofular Cave in northwestern Anatolia (Fig. 4), which reflects changes in the $\delta^{18} \mathrm{O}$ of Black Sea surface water (Badertscher et al., 2011). Oxygen isotope analyses were performed on adult ostracod valves of Candona spp. extracted from the $150 \mu \mathrm{m}$ fraction, and analyzed using a Finnigan MAT 253 mass spectrometer with an automated KIEL IV carbonate preparation device.

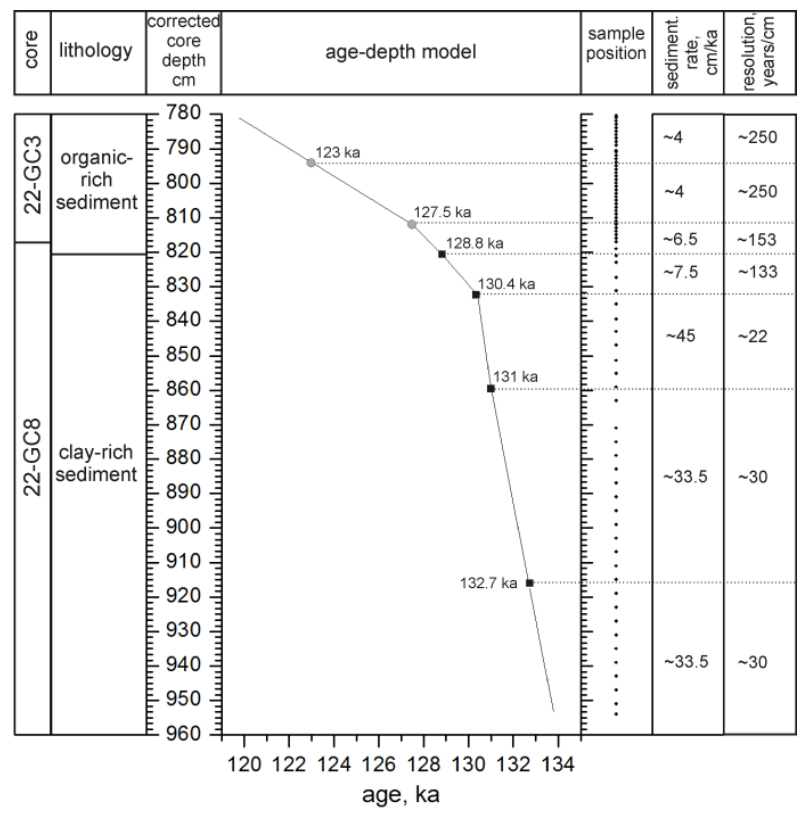

Fig. 3. Stratigraphy of the composite core 22-GC3/8: core indicates palynologically investigated sections of 22-GC3 and 22-GC8; lithology presents the border of the transition from clay-rich to organic-rich sediments; data are shown by corrected core depth; age-depth model indicates position of anchor-points obtained from correlation with pollen (grey circles) and $\delta^{18} \mathrm{O}$ isotopes (black square) (Fig. 4; Table 2); sample position indicates sampling design; sedimentation rate $(\mathrm{cm} / \mathrm{ka})$ and resolution $($ years $/ \mathrm{cm})$ are presented. 


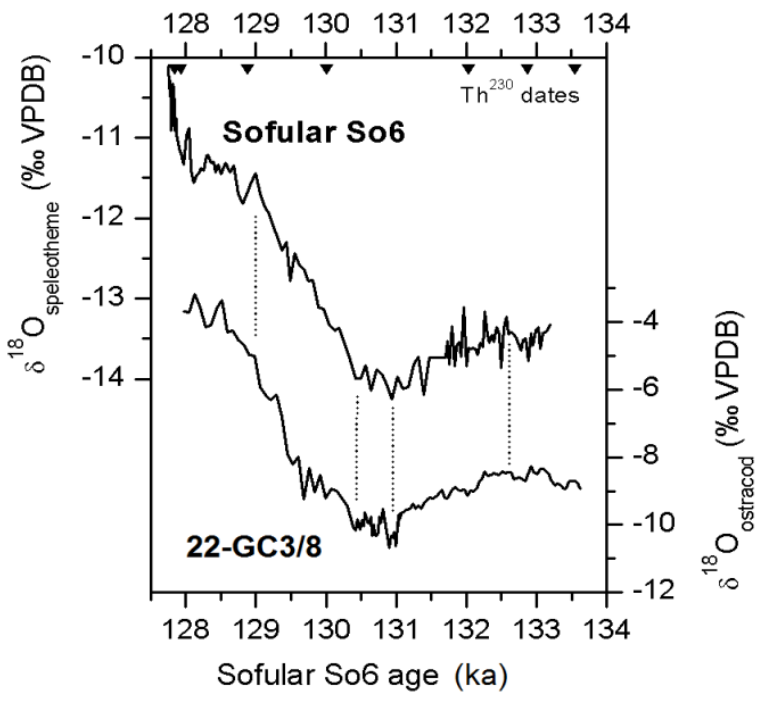

Fig. 4. Correlation of ostracod-based $\delta^{18} \mathrm{O}$ record from core $22-\mathrm{GC} 3 / 8$ with the $\mathrm{Th}^{230}$ dated Sofular Cave $\delta^{18} \mathrm{O}$ record (Badertscher et al., 2011) (modified from Shumilovskikh et al., 2013).

The chronology for the Eemian section of core 22-GC3/8 was established by correlating our pollen record with records from Ioannina 284 (Tzedakis et al., 2003) and Lago Grande di Monticchio (Allen and Huntley, 2009) (Fig. 3, Table 2), both which were independently dated using palaeomagnetic and varve-counting approaches.

Table 2. Stratigraphical control points for sediment cores $22-\mathrm{GC} 3^{(1)}$ and $22-\mathrm{GC} 8^{(2)}$.

\begin{tabular}{|c|c|c|c|}
\hline $\begin{array}{l}\text { Original } \\
\text { depth }(\mathrm{cm})\end{array}$ & $\begin{array}{l}\text { Composite } \\
\text { depth }(\mathrm{cm})\end{array}$ & Description & Age (ka) \\
\hline $794^{1}$ & 794 & $\begin{array}{l}\text { pollen-stratigraphic correlations to Monticchio (Allen and Huntley, 2009) and Ioannina } 284 \\
\text { (Tzedakis et al., 2003) pollen records }\end{array}$ & 123 \\
\hline $812^{1}$ & 812 & $\begin{array}{l}\text { pollen-stratigraphic correlations to Monticchio (Allen and Huntley, 2009) and Ioannina } 284 \\
\text { (Tzedakis et al., 2003) pollen records }\end{array}$ & 127.5 \\
\hline $809.5^{2}$ & 820.5 & $\begin{array}{l}\text { correlation of ostracod } \delta^{18} \mathrm{O} \text { record with }{ }^{230} \mathrm{Th} \text { dated Sofular Cave } \delta^{18} \mathrm{O} \text { record (Badertscher et } \\
\text { al., 2011) }\end{array}$ & 128.8 \\
\hline $821.5^{2}$ & 832.5 & $\begin{array}{l}\text { correlation of ostracod } \delta^{18} \mathrm{O} \text { record with }{ }^{230} \mathrm{Th} \text { dated Sofular Cave } \delta^{18} \mathrm{O} \text { record (Badertscher et } \\
\text { al., 2011) }\end{array}$ & 130.4 \\
\hline $848.5^{2}$ & 859.5 & $\begin{array}{l}\text { correlation of ostracod } \delta^{18} \mathrm{O} \text { record with }{ }^{230} \mathrm{Th} \text { dated Sofular Cave } \delta^{18} \mathrm{O} \text { record (Badertscher et } \\
\text { al., 2011) }\end{array}$ & 131 \\
\hline $905.5^{2}$ & 916.5 & $\begin{array}{l}\text { correlation of ostracod } \delta^{18} \mathrm{O} \text { record with }{ }^{230} \mathrm{Th} \text { dated Sofular Cave } \delta^{18} \mathrm{O} \text { record (Badertscher et } \\
\text { al., 2011) }\end{array}$ & 132.7 \\
\hline
\end{tabular}

Two pollen-stratigraphic anchor points were used for the core chronology. The first anchor point at $127.5 \mathrm{ka}$ represents the arboreal pollen maximum of $\sim 90 \%$ in the pollen record 22-GC3/8, correlated with that of Monticchio ( 80\%) and Ioannina 284 ( 90\%) records. The second anchor point at 123 ka represents the distinct increase in Fagus (up to $25 \%$ ) and Carpinus betulus (up to $25 \%$ ) pollen percentages in the 22-GC3/8 record, which 
corresponds to the second arboreal pollen maximum ( $90 \%)$ in the Monticchio record (zone 21c) and the increase in Carpinus betulus pollen (up to 40\%) in the Ioannina 284 record (Shumilovskikh et al., 2013). The ages for the studied sections of core 22-GC3/8 were calculated using linear interpolation between the anchor points (Fig. 3; Table 2).

\section{Palynological analysis}

A total of 73 samples, each consisted of $1 \mathrm{~cm}^{3}$ of wet sediment, were taken for palynological analyses in core 22-GC3/8. The organic-rich part was sampled from core 22GC3 $(780.5-816 \mathrm{~cm})$ at $1 \mathrm{~cm}$ intervals and the lower clay-rich part was sampled from core 22GC8 (original depth 806-943 cm; corrected depth 817-954 cm) every 2 to $4 \mathrm{~cm}$. In order to calculate pollen concentrations, we added one or two Lycopodium spore tablets (Batch No 177745) to each sample. The samples for microscopic analysis were prepared using standard methods, including cold $10 \% \mathrm{HCl}$, sieving through a metallic sieve $(150 \mu \mathrm{m})$, cold $71-74 \%$ HF (two nights), acetolysis and sieving through a nylon sieve (1-2 $\mu \mathrm{m})$ with an ultrasonic bath. Routine counting was carried out at $400 \times(1000 \times)$ magnification. We followed the pollen and spore nomenclature of Chester and Raine (2001) and Beug (2004), whilst fungal spores were identified using Kuprevich and Ul'yanishchev (1975) for rusts, Vanky (1994) for smut fungi, Bell (2005) and Doveri (2007) for coprophilous fungi, and van Geel et al. (2003) for Glomus-type. To calculate pollen and spore percentages, we counted a minimum of 300350 identifiable pollen grains per sample. The diagram (Fig. 5) was constructed using the software C2 (version 1.6.6) (Juggins, 2003). Count data are available through the PANGAEA database (www.pangaea.de).

The pollen diagram was subdivided into local zones, which were established visually by comparing changes in the principal taxa percentages and supported by the results of biome score calculation. For the purpose of biome reconstructions we assigned pollen taxa to plant functional types (Shumilovskikh et al., 2012) and, based on the plant functional types contributing to each biome, classified pollen spectra to biomes, following the method presented by Prentice et al. (1996).

\section{Dinoflagellate cysts analysis}

For the organic-rich part of sediment core $(780.5-816 \mathrm{~cm})$ we used our recently published dinocyst data (Shumilovskikh et al., 2013). The lower sediments $(817-954 \mathrm{~cm})$ contain species resistant to acetolysis (Pyxidinopsis psilata, Spiniferites cruciformis), therefore, the dinocyst counting was carried out using residues prepared for palynological 
analysis. For the purpose of this paper we present 1) dinocyst concentrations, counted separately for freshwater/brackish and marine indicators; 2) percentages sums of thermophilic taxa, including cysts with subtropical/tropical distribution, and of fully marine taxa, indicative for sea surface salinity (SSS) $>28$ as defined in Shumilovskikh et al. (2013).

\section{Sedimentological investigations}

The determination of total inorganic carbon (TIC) was obtained by an elemental analyser multi EA®2000 (Analytik Jena) equipped with $2 \mathrm{~m} \mathrm{HClO}_{4}$ for $\mathrm{CO}_{2}$ liberation measured by NDIR detection. Depending on the amount of carbonate, sub-samples of 20 to $200 \mathrm{mg}$ of the freeze-dried and homogenized sediment were used.

For determination of the amount of IRD, sediment sub-samples $\left(10 \mathrm{~cm}^{3}\right)$ were taken every $1 \mathrm{~cm}$, wet-sieved and particles $>125 \mu \mathrm{m}$ were counted under a light microscope.

\section{Results}

\section{Pollen and fungal spores}

In total, 123 pollen types were identified. Rare taxa are not included in the diagram (Fig. 5) for simplification. The pollen diagram is divided in seven pollen zones.

Zone 22GC-G1 (954-901cm, 134-132.2 ka) shows high percentages of non-arboreal pollen (NAP) (65-85\%) with mainly Artemisia and Chenopodiaceae. Pollen of steppe shrubs Hippophaë, Ephedra distachia-type, Ephedra fragilis and high scores (15-20) of the steppe biome (STEP) are characteristic. Arboreal pollen (AP) is represented by Pinus diploxylontype and Quercus robur-type with occasional occurrence of euxinian (Ulmus/Zelkova, Corylus, Fagus, Alnus, Castanea, Tilia) and Mediterranean (Phillyrea, Pistacia) taxa. The pollen concentration is very low $\left(1.4 \times 10^{3}-3.5 \times 10^{3}\right.$ grains $\left./ \mathrm{cm}^{3}\right)$. Among fungi, Glomus-type, Sporormiella-type and Podospora-type, spores of smuts (Urocystis, Thecaphora) and rusts winter spores (Puccinia-type) occur.

In zone 22GC-G2 (901-841 cm, 132.2-130.6 ka), AP decreases to 10-20\%, in line with decreasing Pinus diploxylon-type and increasing Artemisia and Chenopodiaceae percentages. Concentrations vary between $1.7 \times 10^{3}$ and $6.98 \times 10^{3} \mathrm{pollen} / \mathrm{cm}^{3}$.

Zone 22GC-G3 $(841-820 \mathrm{~cm}, 130.6-128.7 \mathrm{ka})$ is marked by an increase in Quercus robur-type (2-13\%) and in scores of temperate deciduous (TEDE) biome, whereas Pinus diploxylon-type percentages remain low and Hippophaë decrease. Concentrations increase up to $8.16 \times 10^{3}-11.26 \times 10^{3}$ pollen $/ \mathrm{cm}^{3}$. The decrease in Glomus-type and Sporormiella-type is characteristic for this zone. 

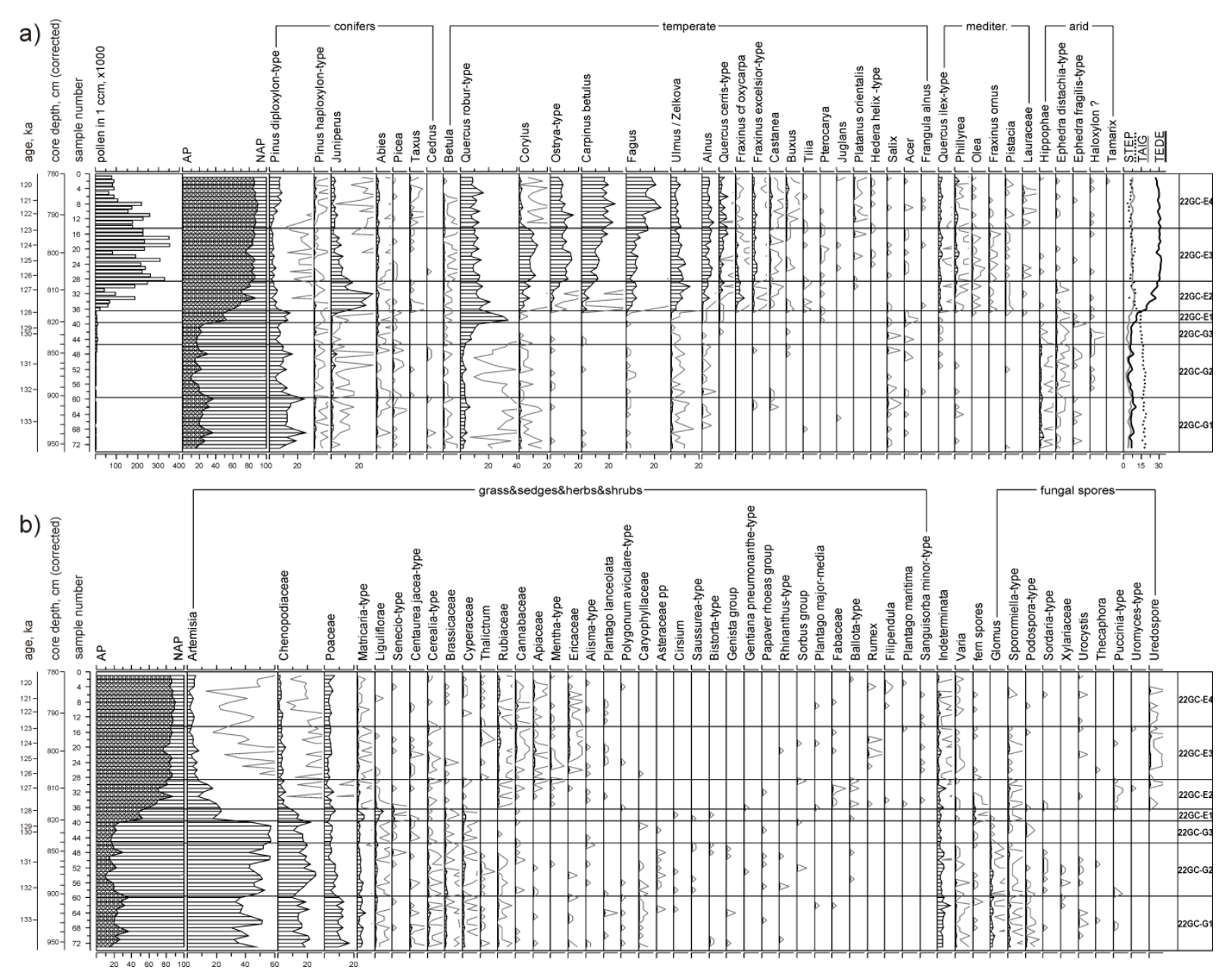

Fig. 5. Simplified pollen diagram (\%) for the analysed part of the core 22-GC3/8: a) arboreal pollen (AP) and biome scores for selected biomes; b) non-arboreal pollen (NAP) and fungal spores. A $\times 10$ exaggeration line (grey) of the horizontal scale is used to show changes in low taxa percentages.

Zone 22GC-E1 $(820-815.5 \mathrm{~cm}, 128.7-128 \mathrm{ka})$ corresponds to a significant increase in AP (53\%), mainly Quercus (20-34\%), Pinus (10-15\%) and Juniperus (1-5\%). NAP values decrease due to a decline in Artemisia and Chenopodiaceae, whereas percentages of other Asteraceae (Matricaria-type, Cichorioideae, Senecio-type) and of Poaceae slightly increase.

Zone 22GC-E2 (815.5-807.5 cm, 128-126.4 ka) shows a further increase in AP values (60-87\%) and a Juniperus maximum (10-30\%). This zone is marked by increasing pollen concentrations of up to $249 \times 10^{3}$ grains $/ \mathrm{cm}^{3}$ and high percentages of euxinean taxa: Corylus, Carpinus betulus, Fagus, Fraxinus cf. oxycarpa, Alnus (each 1-7\%), accompanied by Fraxinus excelsior, Castanea, Tilia, Pterocarya, Ostrya-type. TEDE biome scores reach 2029. Summer spores of rusts (uredospores) occur in the sediments.

Zone 22GC-E3 (807.5-793.5 cm, 126.4-122.9 ka) is characterized by a Corylus maximum (7-13\%) and by high percentages of Carpinus betulus (6-19\%), Ostrya-type (614\%), Quercus robur-type (7-15\%), Fagus (3-10\%), accompanied by Ulmus/Zelkova, Alnus, 
Fraxinus excelsior-type, and Fraxinus cf. oxycarpa. Remarkable here is the continuous occurrence of Ericaceae (1\%). Thermophilic taxa such as Castanea, Tilia, Buxus, Ilex, Pterocarya, Hedera helix, Quercus ilex-type, Phillyrea, Olea, Pistacia, Fraxinus ornus occur occasionally. Pollen concentrations reach a maximum value of $355 \times 10^{3}$ grains $/ \mathrm{cm}^{3}$ in this zone. Uredospores remain constant.

The zone 22GC-E4 $(793.5-780 \mathrm{~cm}, 122.9-119.5 \mathrm{ka})$ is marked by a decline of Corylus (0.5-2.5\%) and an increase of Fagus (11-25\%) and Carpinus betulus (14-24\%) with a higher occurrence of Taxus and Buxus pollen. At a core depth 787-789 cm ( 121.8-121.3 ka) Pinus increases up to $6-9 \%$. Concentrations decrease to $64.1 \times 10^{3}-258 \times 10^{3}$ pollen $/ \mathrm{cm}^{3}$. Spores of Sporormiella-type become almost absent.

\section{Total inorganic carbon, ice rafted detritus, dinocyst records}

Selected proxies used to characterise the Black Sea surface conditions during the penultimate deglaciation are presented in Fig. 6. TIC values vary between 0.1 and $2.1 \mathrm{wt} \%$ during $133.5-130.4 \mathrm{ka}$ and increase from 1.8 at $130.4 \mathrm{ka}(832.5 \mathrm{~cm})$ to $5.8 \%$ at $128.5 \mathrm{ka}$ $(818.5 \mathrm{~cm})$. The amounts of IRD (Fig. $5 \mathrm{~d}$ ) in the samples vary considerably from 0 to 463 grains $/ 10 \mathrm{~cm}^{3}$ and exhibit several alternating periods of low and high amounts. IRD minima correlate with several distinct maxima (400-2600 cysts $/ \mathrm{cm}^{3}$ ) in the dinocyst record (Fig. 5c) and low dinocyst concentrations (11-115 cysts $/ \mathrm{cm}^{3}$ ) coincide with high amounts of IRD. An oscillating increase in dinocyst concentrations $\left(401-14000\right.$ cysts $\left./ \mathrm{cm}^{3}\right)$ is observed from 851 cm ( 130.8 ka) onwards. After $130.4 \mathrm{ka}(833 \mathrm{~cm})$ IRD disappears, while freshwater/brackish dinocysts increase rapidly (Figs. 6 and 7).

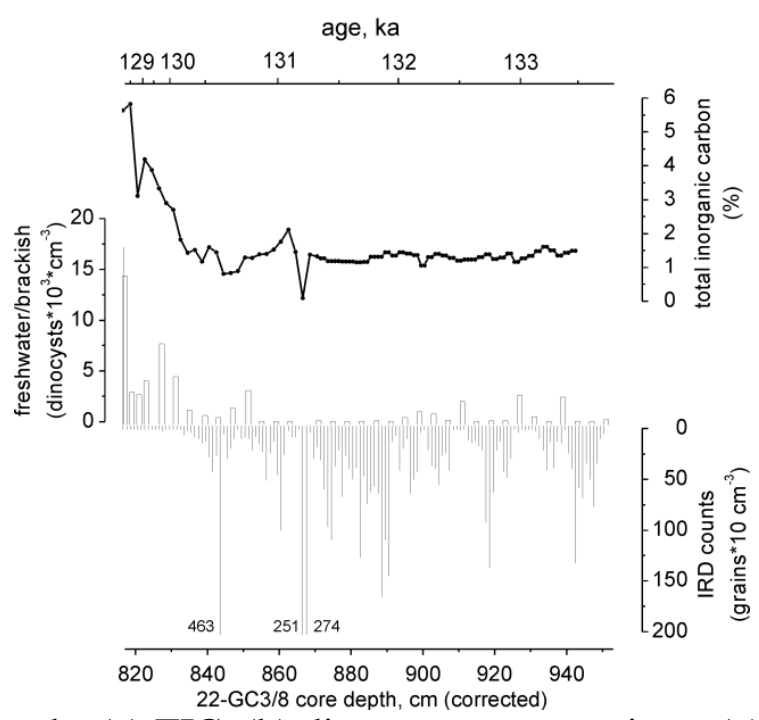

Fig. 6. Palaeoclimate records: (a) TIC, (b) dinocyst concentrations, (c) ice rafted detritus (IRD) from core 22-GC3/8 versus depth ( $\mathrm{cm}$, corrected) and age (ka). Note that three IRD maxima are not presented on the figure. 


\section{Discussion}

\section{Climate instability during the penultimate glacial/interglacial transition}

We would like to mention potential chronological uncertainties of the 22-GC3/8 record, which is derived from the alignment of the $\delta^{18} \mathrm{O}$ ostracod record and pollen spectra to other records (Fig. 3; Table 2). The alignment of 22-GC3/8 $\delta^{18} \mathrm{O}$ ostracod record to the preciselydated Sofular Cave record is valid as the stalagmite and marine sediments show a strong similarity across the last deglaciation when both records are dated independently (Fleitmann et al., 2009; Badertscher et al., 2011). Therefore, age uncertainties of the 22-GC3/8 record for the interval between 134 and 128 ka are most likely in the range of only a few hundred years. However, age uncertainties are increasing between 128 and $119 \mathrm{ka}$ as the 22-GC3/8 chronology is then based on a correlation with pollen records from Europe. Recent works demonstrate that pollen-based age estimations can be appropriated for the last $20 \mathrm{ka}$ (Giesecke et al., 2013). However, age errors at the interglacial scale could be greater than $1 \mathrm{ka}$.

\section{Climate instability during the penultimate glacial-interglacial transition}

Based on several proxies from sediment cores 22-GC3/8, the environmental and climatic conditions of the Northern Anatolia / Black Sea region during the penultimate deglaciation can be characterised in close detail.

One of the most important indicators of long-term environmental changes is the period of depleted ostracod-based $\delta^{18} \mathrm{O}$ values (Fig. 7a) between $\sim 130.4$ and $131.7 \mathrm{ka}$, which shows a very similar pattern to the $\delta^{18} \mathrm{O}$ signal from Sofular (Fig. 4). According to Badertscher et al. (2011), the depleted $\delta^{18} \mathrm{O}$ signal in the Sofular record indicates a melt-water pulse from the Eurasian ice sheets and inflow of water from the Caspian Sea into the Black Sea. Occurrences of IRD in cores $22-\mathrm{GC} 3 / 8$, presently located $\sim 70 \mathrm{~km}$ off the coast, is explained by the transport in coastal ice that could be formed at the southern Black Sea coast during extremely cold winters (Nowaczyk et al., 2012), similar to modern coastal ice formation in the northern Black Sea (Özsoy and Ünlüata, 1997). The indicator value of IRD for cold winters is strengthened by its correlation with dinocyst concentrations (Fig. 6b-c), where maxima (minima) indicate an increased (decreased) primary productivity (Pospelova et al., 2006; Shumilovskikh et al., 2012). TIC primarily reflects the amount of authigenically formed carbonate at the sea surface related to $\mathrm{CO}_{2}$-assimilation and $\mathrm{pH}$-increase by phytoplankton activity. Additionally TIC includes a minor fraction of detrital carbonates originating from 
terrestrial erosion. Furthermore, the abundance of mycorrhizal conidiospores of Glomus-type is used as an additional indicator for soil erosion (van Geel et al., 2003) (Fig. 5b).

The period preceding the melt-water pulse ( 134-131.7 ka), IRD (Fig. 6c) and dinocyst concentrations (Fig. 6b) suggest unstable environmental conditions characterised by rapid alternations of warm and cold phases (Fig. 7b, c). The dominance of Artemisia, Chenopodiaceae and Poaceae with relatively high percentages of Pinus (Fig. 5, 22GC-G1) reveals the presence of open steppe landscapes with Pinus stands, indicating a rather continental and arid climate. The low TIC content until $130.4 \mathrm{ka}$ BP originates just from detrital carbonate (as determined by bulk $\delta^{18} \mathrm{O}$ measurements not shown here) and the lacking contribution of authigenic carbonate indicates both reduced phytoplankton productivity and relatively cold conditions.

During the melt-water pulse ( 131.7-130.4 ka) (Fig. 7a), high IRD concentrations (Fig. $7 c)$ suggest a more frequent occurrence of cold winters. Low dinocyst concentrations also indicate relatively low sea-surface temperatures, which were too cold for dinoflagellate blooms and cyst production (Fig. 7b). The spreading of steppe, indicated by the increase in Chenopodiaceae and decrease in Pinus (Fig. 5, 22GC-G2), indicates more arid conditions than during the previous period.

After the melt-water pulse, initial warming is indicated by several proxies in core 22GC3/8 (Fig. 7). Increasing primary productivity since $\sim 130.4 \mathrm{ka}$ is indicated by higher dinocyst concentrations (Figs. $6 \mathrm{~b}$ and $7 \mathrm{~b}$ ) and by increasing authigenic carbonate production shown by higher TIC values (Fig. 6a). Winter sea-surface temperatures $>0{ }^{\circ} \mathrm{C}$ are indicated by the complete absence of IRD after $\sim 130.4$ ka (Figs. 6c and 7c), whereas warmer/wetter conditions on land since $\sim 130.5 \mathrm{ka}$ are indicated by spreading of oak and a significant increase in temperate deciduous (TEDE) biome scores (Figs. 5 and 7e.3). At the same time, the Glomus-type becomes rare (Fig. 5b), indicating a decrease in soil erosion as a result of to the development of a denser vegetation cover. It is important to mention that the increase in Quercus during the deglaciation is a characteristic feature in Mediterranean pollen records (Sánchez Goñi et al., 1999; Tzedakis et al., 2003; Allen and Huntley, 2009), indicating that oak is one of the most sensitive taxa to initial warming in the Mediterranean region. Aquatic and terrestrial proxy records from core 22-GC3/8 show clear evidence for a rapid ecosystem response to initial warming after the end of the melt water pulse at $\sim 130.5-130.4 \mathrm{ka}$ (within the accepted age-depth model), which is close to the estimations of Brauer et al. (2007) for Lago di Monticchio (Fig. 1) at 130.55 ka. 


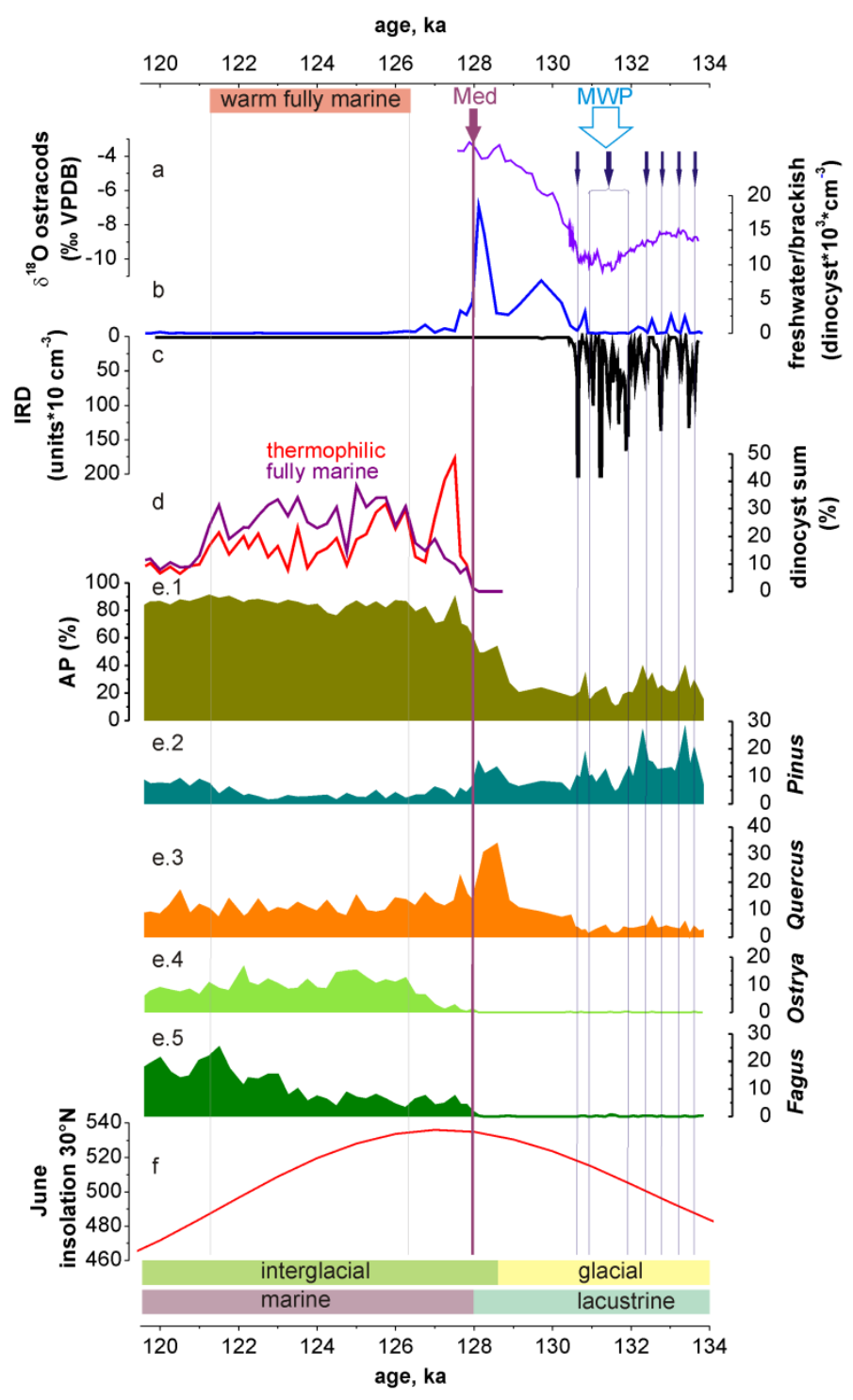

Fig. 7. Summary plot of records from $22-\mathrm{GC} 3 / 8$ indicating environmental changes in Northern Anatolia and the Black Sea between 134 and119 ka BP: (a) $\delta^{18} \mathrm{O}$ ostracod record from core 22-GC3/8; (b) concentration of freshwater/brackish dinocysts in $1 \mathrm{~cm}^{3}$ of core 22GC3/8; (c) ice rafted detritus (IRD) $/ 10 \mathrm{~cm}^{3}$ (note that three maxima are not presented, details in Fig. 6c); (d) sums of thermophilic (red) and fully marine (purple) dinocyst taxa percentages (Shumilovskikh et al., 2013); (e) percentages of arboreal pollen (e.1) and of selected pollen taxa: e.2 Pinus diploxylon-type (Pinus), e.3 deciduous Quercus (Quercus), e.4 Ostrya-type (Ostrya), e.5 Fagus (Fagus); (f) June insolation at $30^{\circ} \mathrm{N}$ (Berger and Loutre, 1991). Lightblue arrow illustrates melt-water pulse (MWP) (after Badertscher et al., 2011), purple arrow onset of Mediterranean inflow (Med), indicated by increase in marine species percentages (d), six dark-blue arrows - cold events during the penultimate transition, indicated by decrease in dinocyst concentrations (b) and increase in IRD (c). Yellow rectangle shows glacial period; green - Eemian, defined by AP (e.1) exceeding 50\%; blue - lacustrine conditions in the Black Sea; purple - marine conditions due to Mediterranean inflow.

In accordance to Brauer et al. (2007), we do not find clear indications for a Younger Dryas-type event in the records from core 22-GC3/8. The fluctuations of dinocyst/IRD abundances suggest unstable climate conditions with several cold phases of 200 to 300 years 
duration and several warm phases lasting approximately 50 to 200 years between $~ 133.4$ and $130.6 \mathrm{ka}$ (Fig. 7). These short events took place before and after the melt water pulse and do not show such a pronounced impact as the Younger Dryas, which was recorded by several proxies in core 22-GC3 as an interruption of the initial warming during the late glacial (Shumilovskikh et al., 2012). The longest cold period $(\sim 130.4-131.7 \mathrm{ka})$ during the penultimate deglaciation was the melt water pulse (Fig. 7), documented before the initial warming, and we suggest its possible correlation to Heinrich event 11 (Heinrich, 1988; Hemming, 2004).

\section{Vegetation and climate changes in Northern Anatolia during the last interglacial}

Fairbridge (1972) defined an interglacial as a "certain formation characterized by an assemblage of sediments, soils, fauna and flora, that are characteristic of climatic conditions generally as warm as or warmer than today". Based on this definition and considering forests as the potential interglacial vegetation of Northern Anatolia (Mayer and Aksoy, 1986) we define the onset of the LI by an abrupt increase in AP to 50\% (Fig. 5, 22GC-E1). This approach is controlled by pollen reconstructions from core 22-GC3, where the Younger Dryas/Holocene transition was clearly indicated by an increase in AP to 50\% (Shumilovskikh et al., 2012).

Based on vegetation changes recorded in core $22-\mathrm{GC} 3 / 8$, four principal phases can be distinguished during the LI. The succession starts with the Quercus maximum at $\sim 128.7 \mathrm{ka}$ and Juniperus maximum at $\sim 128$ ka (Fig. 5), interpreted as a period of hot summers and strong seasonal moisture deficit, similar to the present climate in central Anatolia (Mayer and Aksoy, 1986). The time lag of $\sim 700$ yr between oak and juniper maxima could be either related to a real change in vegetation cover or also to changes of sedimentation conditions in the Black Sea. The rapid rise of the global sea level during the Eemian (e.g. Rohling et al., 2007) caused the inflow of salty Mediterranean waters into the Black Sea basin, considerably changing its hydrology (Shumilovskikh et al., 2013) and establishing marine conditions in the basin within $\sim 700$ years of the onset of interglacial conditions (Fig. 6). The inflow of salt water from the Mediterranean induced the formation of anoxic conditions, allowing good preservation of organic material, which is especially important for pollen taxa with thin exine, such as Juniperus, Taxus, and Cyperaceae. Regardless of the time lag, 30\% Juniperus in the sample, which is generally underestimated in pollen records (Beer et al., 2007), suggests a very dense cover of Juniperus on the Pontic Mountain slopes at the beginning of the Eemian. Generally wetter/warmer conditions between $~ 128.7$ and $126.4 \mathrm{ka}$ are indicated by the spread 
of Fagus, Corylus, Carpinus betulus, Carpinus orientalis/Ostrya, Castanea (Fig. 5a). Fraxinus cf. oxycarpa, Alnus, Ulmus/Zelkova, Pterocarya, and Salix (Fig. 5a) suggest the development of riparian forests and/or a higher river discharge and resultant increased transport of pollen from these vegetation types towards the Black Sea.

During the second phase lasting from $\sim 126.4$ to $122.9 \mathrm{ka}$ (22GC-E3), the pollen spectra are dominated by Ostrya-type, Carpinus betulus, Corylus and Quercus, which indicate the establishment of relatively open mixed forests. The deciduous submediterranean species Ostrya carpinifolia and Carpinus orientalis (Meusel and Jäger, 1987) suggest a climate characterised by warm summers and mild winters with year-round precipitation (Mayer and Aksoy, 1986). Winter temperatures $>0{ }^{\circ} \mathrm{C}$ is also suggested by occurrence of thermophilous Pterocarya and increased Olea, Phillyrea, Fraxinus ornus, Pistacia, and Laurus (Fig. 5a), indicating the presence of Mediterranean vegetation in the dry lowlands of the Pontic Mountains with similar to modern conditions.

The third period (22GC-E4) is marked by increased Fagus abundances (25\%) at $~ 122.9$ ka (Figs. 5a and 7e.5). The spread of Fagus is indicative for the onset of a cool temperate climate, with average temperatures of $16.1-20.5^{\circ} \mathrm{C}$ for the warmest and $-1.5--3.2^{\circ} \mathrm{C}$ for the coldest months by the distribution limits of oriental beech (Fang and Lechowicz, 2006). This is similar to pollen-based estimates of Huntley et al. (1989) with -1 to $-4^{\circ} \mathrm{C}$ in January and $18^{\circ} \mathrm{C}$ in July. The establishment of closed beech forests correlates with a decrease in percentages of shade-intolerant Corylus (22GC-E4). This suggests that factors other than climate, such as competition for light (Božilova and Djankova, 1976), were important.

The onset of colder and dryer conditions, characteristic for the fourth phase (Aalsberg and Litt, 1998; Klotz et al., 2003), is evidenced by an increase in percentages of the eurythermic conifer Pinus after $\sim 121.5$ ka (Fig. 7e.2).

Fungal spores provide additional information about environmental changes on land . Spores of facultative coprophilous fungi such as Sporormiella-type, Sordaria-type and Podospora-type occur more often during the glacial period and decline at the onset of the interglacial conditions (Fig. 5b). Similar to the late glacial-Holocene record derived from core 22-GC3 (Shumilovskikh et al., 2012), we interpret higher concentrations of fungal spores as terrestrial input of eroded decaying organic matter. The increase spores of rusts at $\sim 128 \mathrm{ka}$ (Fig. 5b) coincides with the increase in the total amount of arboreal pollen and is thus indicative for increased numbers of host plants: either of particular host species or simply increased plant biomass. Furthermore, changes in the percentages of winter and summer rust spores are most likely related to a longer growing season. Summer spores are produced by 
obligate parasitic rust fungi for vegetative reproduction mainly during the summer (Kuprevich and Ul'yanishchev, 1975) and thus require a sufficiently long growing season. In contrast, winter spores (generative reproduction) occur more often during the Juniperus-phase (22GCE2), indicative for a rather continental climate with moisture deficit and short vegetation period. The smut fungi represent the other big group of plant pathogens occurring in core 22GC3/8 (Fig. 5b). These fungi infect only sedges, grasses and herbs (Vánky, 1994) and their stable occurrence in the record is not connected to changes in tree biomass.

\section{The Black Sea region in the context of the Eemian vegetation history of Europe}

Although the end of the penultimate deglaciation in Northern Anatolia is characterized by a dominance of Artemisia, Chenopodiaceae and Poaceae, the presence of Pinus and Quercus in the pollen record 22-GC3/8 (Figs. 5 and 7e) suggest forest-steppe landscapes with oaks and pines. Furthermore, the presence of Fagus, Carpinus betulus, Ostrya-type, Corylus, Castanea, Tilia and Mediterranean plants such as Olea, Pistacia, Phillyrea (Fig. 5a) provides clear evidence for glacial tree refugia (sensu Tzedakis and Bennett (1995)) in the Pontic Mountains. This makes Northern Anatolia comparable to Southern Europe, where vegetation developments proceeded without migration lags.

The general development of vegetation succession in Northern Anatolia obtained from core 22-GC3/8 is comparable with other pollen records from the Black Sea region (Fig. 1, Table 3), such as the Black Sea record 379A (Koreneva and Kartashova, 1978), Caucasian records (Shatilova, 1974) and Staro Orjachovo from Bulgaria (Božilova and Djankova, 1976), Nosovo-1 (Spiridonova, 1991) from the Don delta. The latter, although missing the midEemian, demonstrates generally a more continental character of the vegetation at the beginning of the Eemian as revealed by the dominance of eurythermic Pinus and the boreal Betula and Picea. Comparison of the Black Sea records (Table 3) reveals Fagus as an important taxon for the Black Sea region: 25\% of Fagus in 22-GC3/8, 20\% in the Black Sea core 379A, 10-20 \% in Georgian records, and $20 \%$ in Staro Orjachovo (Fig. 8).

The general picture clearly demonstrates that beech was widespread in the coastal mountains surrounding the Black Sea during the Eemian, which is very interesting considering that beech played a negligible role in European vegetation during the last interglacial (Lang, 1994) (Fig. 8, Table 4). Indeed, Eemian pollen sequences in southern Europe (Wijmstra, 1969; Woillard, 1978; De Beaulieu and Reille, 1984; Follieri et al, 1988; De Beaulieu and Reille, 1992a, 1992b; Reille et al., 1998; Tzedakis, 1999, 2000; Tzedakis et al., 2003; Allen and Huntley, 2009) reveal the absence or a rare occurrence ( 5\%) of Fagus 
pollen, similar to northwestern European sequences (Lang, 1994) (Fig. 8). Since Fagus was present in southern Europe during the Pleistocene (Magri et al., 2006), these different patterns in its distribution during the Eemian point out differences in competitive ability of Fagus in the Black Sea region and southern Europe. While the evaluation of the local factors, such as interspecific interactions, diseases and local environment, is difficult on this large spatial scale, below we discuss climatic and genetic factors of beech distribution in Europe during the Eemian.

Table 3. Correlation of pollen record 22-GC3/8 to the Black Sea record (Koreneva and Kartashova, 1978) and terrestrial records from the Azov/Black Sea coastal regions (Shatilova, 1974; Spiridonova, 1991; Božilova and Djankova, 1976). Zones (in brackets) are given according to references.

\begin{tabular}{|c|c|c|c|c|}
\hline 22-GC3/8 (this study) & $\begin{array}{l}\text { 379A (Koreneva and } \\
\text { Kartashova, 1978) }\end{array}$ & $\begin{array}{l}\text { Caucasian records } \\
\text { (Shatilova, 1974) }\end{array}$ & $\begin{array}{c}\text { Nosovo-1 } \\
\text { (Spiridonova, 1991) }\end{array}$ & $\begin{array}{l}\text { Staro Orjachovo } \\
\text { (Božilova and } \\
\text { Djankova, 1976) } \\
\end{array}$ \\
\hline \multirow[t]{2}{*}{ no data } & $\begin{array}{c}\text { Artemisia- } \\
\text { Chenopodiaceae (10/9 } \\
\text { CC) }\end{array}$ & no data & Asteraceae-Pinus & no data \\
\hline & \multirow{4}{*}{$\begin{array}{l}\text { Pinus-Ulmus-Fagus- } \\
\text { Carpinus-Alnus-Picea } \\
\text { (10 CC })\end{array}$} & \multirow{4}{*}{$\begin{array}{c}\text { Pinus-Abies- } \\
\text { Carpinus-Fagus- } \\
\text { Quercus-Castanea- } \\
\text { Ulmus-Alnus } \\
\text { (Karangat zone) }\end{array}$} & $\begin{array}{l}\text { Pinus-Picea (VII- } \\
\text { VIII) }\end{array}$ & Pinus-Picea-Abies (R) \\
\hline $\begin{array}{c}\text { Fagus-Carpinus betulus-Ostrya- } \\
\text { Quercus-Pinus (22GC-E4) }\end{array}$ & & & \multirow[b]{2}{*}{ no data } & $\begin{array}{l}\text { Carpinus betulus- } \\
\text { Fagus }(\mathrm{Q}, \mathrm{P})\end{array}$ \\
\hline $\begin{array}{c}\text { Ostrya-Quercus-Corylus- } \\
\text { Carpinus betulus-Fagus (22GC- } \\
\text { E3) }\end{array}$ & & & & $\begin{array}{l}\text { Quercus-Corylus- } \\
\text { Carpinus betulus- } \\
\text { Ostrya }(\mathrm{O})\end{array}$ \\
\hline $\begin{array}{c}\text { Quercus-Pinus-Juniperus- } \\
\text { Artemisia-Ulmus-Fagus-Corylus } \\
\text { (22GC-E1,E2) }\end{array}$ & & & $\begin{array}{l}\text { Pinus-Betula-Picea- } \\
\text { (Quercus) (III-VI) }\end{array}$ & Pinus-Quercus (N) \\
\hline $\begin{array}{l}\text { NAP-Quercus-Pinus (22GC- } \\
\text { G1,G2,G3) }\end{array}$ & $\begin{array}{c}\text { Artemisia- } \\
\text { Chenopodiaceae-Pinus } \\
\text { (11 CC) } \\
\end{array}$ & no data & $\begin{array}{c}\text { NAP-Pinus-Betula- } \\
\text { Picea } \\
\text { (I-II) }\end{array}$ & no data \\
\hline
\end{tabular}

Following the accepted taxonomy (Greuter and Burget, 1981), in Europe, Fagus sylvatica L. consists of two subspecies: Fagus sylvatica L. subsp. orientalis (Lipsky) Greuter \& Burdet and Fagus sylvatica L. subsp. sylvatica. Some authors, including ourselves, consider these taxa as species (Fagus orientalis and Fagus sylvatica) (e.g. Davis,1965-1985; Gömöry et al., 2001), whereas other suggest the existence of several ecotypes within one species Fagus sylvatica (e.g. Denk, 1999a, 1999b; Denk et al., 2002). Both species reveal a high phenotypic diversity (Denk, 1999a, 1999b) and high genetic variability (Denk et al., 2002; Papageorgiou et al., 2008), and can hybridise (Denk, 1999b). Discussing the evolutionary history of Fagus in Europe, Gömöry et al. (1999) and Denk et al. (2002) point out the high genetic variability of Asia Minor populations and suggest that Pleistocene glacial-interglacial cycles played a decisive role for the establishment of modern beech populations. Further details on the Pleistocene history of European beech are provided by Magri et al. (2006), using combined fossil and genetic data. However, oriental beech in the 
Black Sea region was scarcely considered in this study. Unfortunately, pollen of both species belong to the same morphological pollen type Fagus (Beug, 2004), making their palynological separation an impossible task.

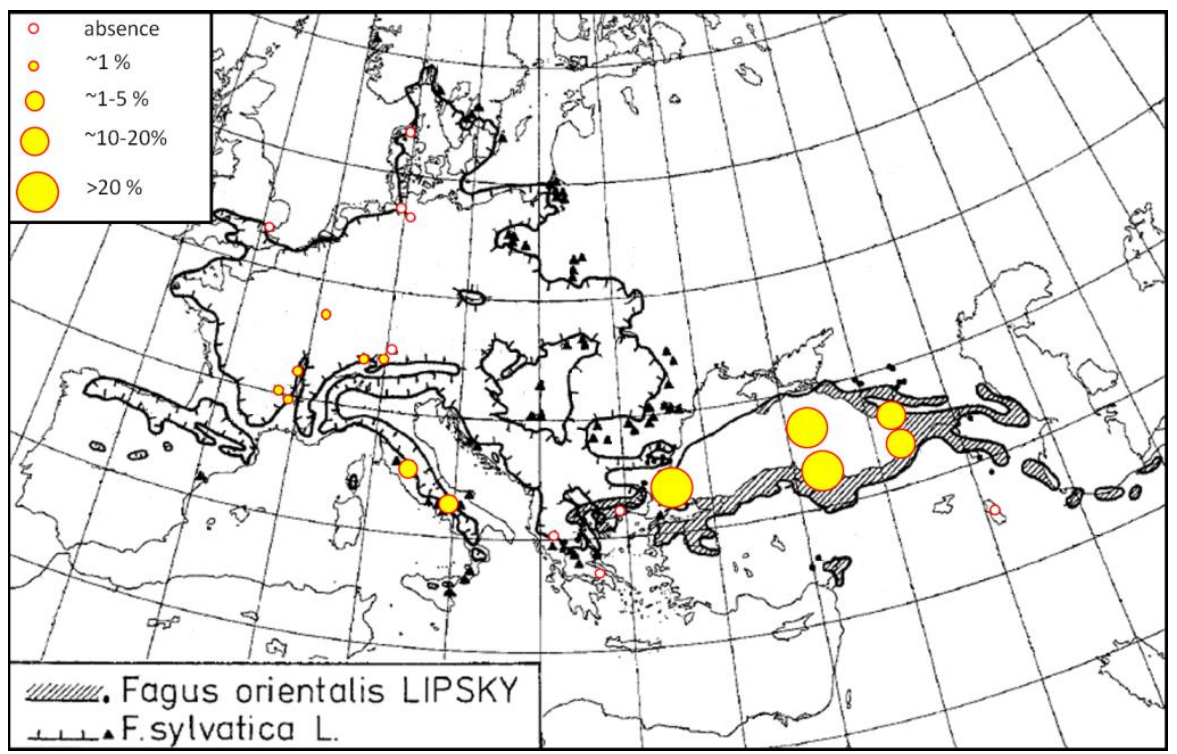

Fig. 8. Modern distribution map of Fagus sylvatica L. and Fagus orientalis Lipsky (based on Meusel and Jäger, 1989) with highest Fagus percentages achieved during the Eemian (Mediterranean records Fig. 1 and Table 1, central and northern European records from Lang (1994)).

From the biogeographical point of view, beech is a typical tree for the cool-temperate zone, and European and oriental beech show very similar climatic limits of distribution (Fang and Lechowicz, 2006). However, phytoecological requirements differ between the two species. For example, species composition of Fagus orientalis forests in Greece consists of thermophilous species with Submediterranean or Balkan distribution, indicating warmer and dryer conditions compared to Fagus sylvatica forests (Bergmeier and Panayotis, 2001). Furthermore, oriental beech is restricted to the Black Sea coastal mountains, whereas the western limits of European beech distribution run through the eastern Stara Planina and Rodopi mountains (Meusel and Jäger, 1989; Gömöry et al., 1999; Denk, 1999b). The fact that the modern distribution of Fagus orientalis coincides well with high pollen percentages of Fagus during the Eemian (Fig. 8) is possibly indirect evidence that oriental beech formed Eemian forests in the Black Sea region, whereas European beech never was a dominant species at that time. This observation challenges the importance of genetic factors for beech forest distribution.

Global and regional climate dynamics can be also related to the Fagus history in Europe. Globally, Eemian climate is characterised by temperatures $2{ }^{\circ} \mathrm{C}$ higher than present, causing melting of glaciers and, therefore, a sea-level $~ 4-6 \mathrm{~m}$ higher than present (Cuffey and Marshall, 2000; Otto-Bliesner, 2006; Rohling et al., 2007). Pollen records from Europe 
correlate well with record 22-GC3/8 (Table 4), indicating warmer summers during the Eemian in response to higher summer insolation (Fig. 7f). The significant spread of Fagus in Northern Anatolia started at $\sim 123 \mathrm{ka}$ and was concurrent with the Carpinus-Picea phase in Europe (Aalsberg and Litt, 1998) (Table 4), which is indicative for a decrease in winter temperature by $5.2^{\circ} \mathrm{C}$ and in summer temperature by $1.4^{\circ} \mathrm{C}$ (Klotz et al., 2003). The isotopic profile of speleothems from Soreq Cave (Israel) indicates a major increase in the annual rainfall coupled with frost-free winters and drought-free summers between 124 and $119 \mathrm{ka}$ (Bar-Matthews et al., 2000). In Northern Iberia, winter cooling by $2{ }^{\circ} \mathrm{C}$ on land and increased annual precipitation by $100-200 \mathrm{~mm}$ is suggested at $121 \mathrm{ka}$ and explained by a southward migration of the polar front (Sánchez Goñi et al., 2005). In summary, the general climate cooling in Europe after $\sim 123 \mathrm{ka}$ can explain an increase in Fagus percentages. However, significant beech pollen quantity between $128-123 \mathrm{ka}$ is difficult to explain by the summerwarm climate during the period of summer insolation maximum (Fig. 7f) and required analysis of climate on regional scale.

Table 4. Correlations between the Eemian pollen record of 22-GC3/8 to equivalent intervals of pollen records of Ioannina (Tzedakis et al., 2003), Monticchio (Allen and Huntley, 2009), MD952042 (Sánchez Goñi et al., 1999), combined pollen stratigraphies for north (Aalbersberg and Litt, 1998) and central (Klotz et al., 2003) Europe and marine isotope stage scale as defined by Shackleton et al. (2003). Zones (in brackets) and ages of their borders are given according to references.

\begin{tabular}{|c|c|c|c|c|c|c|}
\hline $\begin{array}{l}\text { Age } \\
\text { (ka) }\end{array}$ & 22-GC3/8 (this study) & $\begin{array}{l}\text { Ioannina (Tzedakis } \\
\text { et al., 2003) }\end{array}$ & $\begin{array}{l}\text { Monticchio (Allen and } \\
\text { Huntley, 2009) }\end{array}$ & $\begin{array}{l}\text { MD952042 (Sánchez Goñi } \\
\text { et al., 1999) }\end{array}$ & $\begin{array}{l}\text { North and central Europe } \\
\text { (Aalbersberg and Litt, } \\
\text { 1998; Klotz et al., 2003) }\end{array}$ & $\begin{array}{c}\text { MIS } \\
\text { (Shackleton et } \\
\text { al., 2003) } \\
\end{array}$ \\
\hline 115 & \multirow{4}{*}{ no data } & \multirow{5}{*}{$\begin{array}{c}\text { Quercus-Carpinus } \\
\text { betulus-Abies-Pinus- } \\
\text { Poaceae }\end{array}$} & Abies-Quercus-Alnus- Betula & \multirow{5}{*}{$\begin{array}{l}\text { Quercus-Carpinus betulus- } \\
\text { Ericaceae (MD42-5) }\end{array}$} & \multirow{4}{*}{ Pinus-Picea-Abies } & \multirow{17}{*}{$5 \mathrm{e}$} \\
\hline 116 & & & (21a) & & & \\
\hline 117 & & & \multirow{3}{*}{ Quercus-Alnus-Abies (21b) } & & & \\
\hline 118 & & & & & & \\
\hline 119 & \multirow{4}{*}{$\begin{array}{l}\text { Fagus-Carpinus } \\
\text { betulus-Ostrya-Quercus- } \\
\text { Pinus (22GC-E4) }\end{array}$} & & & & \multirow{4}{*}{ Carpinus-Picea } & \\
\hline$\frac{120}{121}$ & & \multirow{3}{*}{$\begin{array}{l}\text { Carpinus betulus- } \\
\text { Quercus-Ostrya- } \\
\text { Pinus }\end{array}$} & \multirow{3}{*}{$\begin{array}{c}\text { Quercus-Ostrya-Carpinus } \\
\text { betulus }(21 \mathrm{c})\end{array}$} & \multirow{3}{*}{$\begin{array}{l}\text { Quercus-Carpinus betulus- } \\
\text { evergreen Quercus- } \\
\text { Mediterranean (MD42-4) }\end{array}$} & & \\
\hline 122 & & & & & & \\
\hline 123 & & & & & & \\
\hline 124 & Ostrya-Quercus- & \multirow{4}{*}{$\begin{array}{l}\text { Quercus-Carpinus } \\
\text { betulus-Pinus- } \\
\text { Ostrya-evergreen } \\
\text { Quercus- } \\
\text { Mediterranean }\end{array}$} & \multirow{4}{*}{$\begin{array}{c}\text { Quercus-Poaceae-Ostrya- } \\
\text { Ulmus-Corylus-Mediterranean } \\
\text { (21d-f) }\end{array}$} & \multirow{3}{*}{$\begin{array}{c}\text { Quercus-evergreen } \\
\text { Quercus-Mediterranean } \\
\text { (MD42-3) }\end{array}$} & \multirow{4}{*}{ Quercetum mixtum-Corylus } & \\
\hline 125 & Corylus-Carpinus & & & & & \\
\hline 126 & $\begin{array}{l}\text { betulus-Fagus (22GC- } \\
\text { E3) }\end{array}$ & & & & & \\
\hline 127 & Juniperus-Quercus- & & & \multirow{3}{*}{$\begin{array}{c}\text { Quercus-Betula- } \\
\text { Cupressaceae-Artemisia- } \\
\text { Chenopodiaceae-Ephedra- } \\
\text { Ericaceae (MD42-2) }\end{array}$} & & \\
\hline 128 & $\begin{array}{l}\text { Ulmus- Pinus-Fagus- } \\
\text { Corylus (22GC-E2) }\end{array}$ & \multirow[b]{2}{*}{$\begin{array}{l}\text { Quercus-Pinus- } \\
\text { Poaceae-Juniperus }\end{array}$} & $\begin{array}{l}\text { Quercus-Poaceae-Artemisia } \\
\text { (22a) }\end{array}$ & & \multirow{3}{*}{ Betula-Pinus } & \\
\hline 129 & $\begin{array}{l}\text { Quercus-Artemisia- } \\
\text { Pinus-Chenopodiaceae- } \\
\text { Juniperus-(22GC-E1) }\end{array}$ & & \multirow{2}{*}{$\begin{array}{c}\text { Poaceae-Artemisia- } \\
\text { Chenopodiaceae-Juniperus } \\
\text { Quercus (22b) }\end{array}$} & & & \\
\hline 130 & Artemisia- & \multirow{4}{*}{$\begin{array}{l}\text { Poaceae-Artemisia- } \\
\text { Quercus-Pinus }\end{array}$} & & \multirow{5}{*}{$\begin{array}{c}\text { Artemisia-Chenopodiaceae- } \\
\text { Ephedra-Poaceae- } \\
\text { Cupressaceae (MD42-1) }\end{array}$} & & \\
\hline 131 & $\begin{array}{l}\text { Chenopodiaceae- } \\
\text { Quercus-Pinus (22GC- } \\
\text { G3) } \\
\end{array}$ & & Poaceae-Artemisia- & & \multirow{4}{*}{ NAP-Betula-Pinus } & \\
\hline 132 & $\begin{array}{c}\text { Artemisia- } \\
\text { Chenopodiaceae-Pinus- } \\
\text { Poaceae (22GC-G2) }\end{array}$ & & $\begin{array}{l}\text { Chenopodaceae-Juniperus } \\
\qquad(22 \mathrm{c})\end{array}$ & & & \\
\hline 133 & \multirow{2}{*}{$\begin{array}{c}\text { Artemisia- Pinus- } \\
\text { Chenopodiaceae- } \\
\text { Poaceae (22GC-G1) }\end{array}$} & & \multirow{2}{*}{$\begin{array}{c}\text { Artemisia-Poaceae- } \\
\text { Chenopodiaceae-Juniperus } \\
\text { (22d) }\end{array}$} & & & \multirow{2}{*}{6} \\
\hline 134 & & no data & & & & \\
\hline
\end{tabular}

Footnote: NAP = non-arboreal pollen; Quercus $=$ deciduous Quercus; Mediterranean = Olea, Pistacia, Phillyrea $;$ Pinus $=$ Pinus diploxylon-type; Ostrya $=$ Ostrya/Carpinus orientalis

On the regional scale, higher than present summer temperatures between 126.4 and $122.9 \mathrm{ka}$, revealed by pollen record 22-GC3/8, correlate well with a period of warm and fully 
marine sea-surface conditions in the Black Sea between 126.5 and 121 ka (Fig. 7), characterized by SSS $>28 \%$ o (presently $18 \%$ ) and minimum SSTs of $7^{\circ} \mathrm{C}$ in winter $\left(4-8^{\circ} \mathrm{C}\right.$ ) and up to $27^{\circ} \mathrm{C}$ in summer $\left(23-25^{\circ} \mathrm{C}\right)$ (Shumilovskikh et al., 2013). Such warm and saline surface conditions were explained by elevated warm and saline Mediterranean water inflow into the Black Sea and by higher than present summer temperatures resulting in increased evaporation (Shumilovskikh et al., 2013). Higher summer temperatures suggest a shift of the beech forest belt to higher than present elevations, meaning further away from the coring site 22-GC3/8, and a spread of Quercus-Ostrya-Carpinus betulus vegetation at lower elevations. Furthermore, increased evaporation from the Black Sea, the main source of precipitation in the Pontic Mountains (Badertscher et al., 2011), may led to a higher transport of moisture to central parts of Anatolia. The increase in atmospheric moisture and higher orographic precipitation on the northern slopes of the Pontic Mountains may have prevented the establishment of typical Mediterranean vegetation there. The second effect implies an increased moisture transport further south, which may have led to an expansion of the beech forest belts towards the central part of Anatolia, consequently pushing pine and oak belts further south. Decreasing temperatures and increasing precipitation at around $\sim 123 \mathrm{ka}$ could have lead to movements of the vegetation belts back northwards, however, new pollen records from Anatolia are required to test this hypothesis.

Briefly, the discussion about Eemian Fagus history in southern Europe is based on observations of very low or absent beech pollen in diagrams, suggesting its negligible role in the vegetation history during the MIS 5e (Magri et al., 2006). Our new data from the Black Sea region provide evidence for the existence of Fagus forests in the present distribution area of Fagus orientalis, opening the discussion about possible factors influencing beech behaviour during the LI in Europe.

\section{Conclusions}

The multiproxy records from the SE Black Sea provide detailed environmental reconstructions in Northern Anatolia between 134-119 ka. Dinocysts and IRD records reveal climatic instability during the penultimate deglaciation, characterised by alterations of shortlived cold and warm events, preceding the melt-water pulse from the Eurasia ice sheet. The main trends in vegetation succession in Northern Anatolia during the Eemian correspond to vegetation changes in Europe. The discrepancy in the spatial extent of Fagus in Europe and Asia Minor during the Eemian highlight the importance of global and regional climatic as well as genetic factors for the beech distribution. 


\section{Acknowledgements}

We warmly thank Mariana Filipova and Eliso Kvavadze for providing publications, the Editor Peter Langdon and anonymous reviewers for critical reading and improving the manuscript, and Laura Sutcliffe for polishing the English. Financial support was provided by the Deutsche Forschungsgemeinschaft (DFG) (BE 2116/20-1) within the SPP 1266 "INTERDYNAMIC".

\section{References}

Aalbersberg, G., Litt, T., 1998. Multiproxy climate reconstructions for the Eemian and Early Weichselian. Journal of Quaternary Science 13, 367-390.

Allen and Huntley, 2009. Last Interglacial palaeovegetation, palaeoenvironments and chronology: a new record from Lago Grande di Monticchio, southern Italy. Quaternary Science Reviews 28, $1521-1538$.

Alpat'ev, A.M., Arkhangel'skii, A.M., Podoplelov, N.Y., Stepanov, A.Y., 1976. Fizicheskaya geografiya SSSR (Evropeiskaya chast'). Vysshaya Shkola, Moscow (in Russian).

Badertscher, S., Fleitmann, D., Cheng, H., Edwards, R.L., Göktürk, O.M., Zumbühl, A., Leuenberger, M., Tüysüz, O., 2011. Pleistocene water intrusions from the Mediterranean and Caspian Seas into the Black Sea. Nature Geoscience, 4, 236-239.

Bahr, A., Lamy, F., Arz, H., Kuhlmann, H., Wefer, G., 2005. Late glacial to Holocene climate and sedimentation history in the NW Black Sea. Marine Geology 214, 309-322.

Bahr, A., Lamy, F., Arz, H., Major, C., Kwiecien, O., Wefer, G., 2008. Abrupt changes of temperature and water chemistry in the late Pleistocene and early Holocene Black Sea. Geochemistry, Geophysics, Geosystems 9, doi:10.1029/2007GC001683.

Bar-Matthews, M., Ayalon, A., Kaufman, A., 2000. Timing and hydrological conditions of Sapropel events in the Eastern Mediterranean, as evident from speleothems, Soreq cave, Israel. Chemical Geology 169, 145-156.

Beer, R., Tinner, W., Carraro, G., Grisa, E., 2007. Pollen representation in surface samples of the Juniperus, Picea and Juglans forest belts of Kyrgyzstan, central Asia. The Holocene 17: 599-611.

Bell, A., 2005. An illustrated guide to the coprophilous Ascomycetes of Australia. Centraalbureau voor Schimmelcultures, Utrecht.

Berger, A., Loutre, M.F., 1991. Insolation values for the climate of the last 10 Million years. Quaternary Science Reviews 10, 297-317. 
Bergmeier, E., Panayotis, D., 2001. Fagus sylvatica forest vegetation in Greece: Syntaxonomy and gradient analysis. Journal of Vegetation Science 12, 109-126.

Beug, H.-J., 2004. Leitfaden der Pollenbestimmung für Mitteleuropa und angrenzende Gebiete. Pfeil, München (in German).

Brauer, A., Allen, J.R.M., Mingram, J., Dulski, P., Wulf, S., Huntley, B., 2007. Evidence for last interglacial chronology and environmental change from Southern Europe. PNAS $104,450-455$.

Božilova, E., Djankova, M., 1976. Vegetation development during the Eemian in the North Black Sea Region. Phytology 4, 25-32.

Chester, P.I., Raine, J.I., 2001. Pollen and spore keys for Quaternary deposits in the northern Pindos Mountains, Greece. Grana 40, 299-387.

Cuffey, K.M., Marshall, S.J., 2000. Substantial contribution to sea-level rise during the last interglacial from the Greenland ice sheet. Nature 404, 591-594.

Davis, P.H., 1965-1985. Flora of Turkey and the East Aegean Islands. Bd. 1-9, Edinburgh.

De Beaulieu, J.-L., Reille, M., 1984. A long Upper Pleistocene pollen record from Les Echets, near Lyon, France. Boreas 13, 111-132.

De Beaulieu, J.-L., Reille, M., 1992a. Long Pleistocene pollen sequences from the Velay Plateau (Massif Central, France). I. Ribains Maar. Vegetation History and Archaeobotany 1, 233-242.

De Beaulieu, J.-L., Reille, M., 1992b. The last climatic cycle at Grand Pile (Vosges, France). Quaternary Science Reviews 11, 431-438.

Denk, T., 1999a. The taxonomy of Fagus in western Eurasia. 1. Fagus sylvatica subsp. Orientalis (=F. orientalis). Feddes Repertorium 110, 381-412.

Denk, T., 1999b. The taxonomy of Fagus in western Eurasia. 2: Fagus sylvatica subsp. sylvatica. Feddes Repertorium 110, 381-412.

Denk, T., Grimm, G., Stögerer, K., Langer, M., Hemleben, V., 2002. The evolutionary history of Fagus in western Eurasia: Evidence from genes, morphology and the fossil data. Plant Systematics and Evolution 232, 213-236.

Djamali, M., de Beaulieu, J.-L., Shah-hosseini, M., Andrieu-Ponel, V., Ponel, P., Amini, A., Akhani, H., Leroy, S.A.G., Stevens, L., Lahijani, H., Brewer, S., 2008. A late Pleistocene long pollen record from Urmia, NW Iran. Quaternary Research 69, 413-420.

Doveri, F., 2007. Fungi fimicoli Italici. A.M.B., Vicenza.

Fairbridge, R.W., 1972. Climatology of a Glacial Cycle. Quaternary Research 2, 283-302. 
Fang, J., Lechowicz, M.J., 2006. Climatic limits for the present distribution of beech (Fagus L.) species in the world. Journal of Biogeography 33, 1804-1819.

Filipova-Marinova, M., Pavlov, D., Coolen, M., Giosan, L., 2012. First high-resolution marinopalynological stratigraphy of Late Quaternary sediments from the central part of the Bulgarian Black Sea area. Quaternary International, doi:10.1016/j.quaint.2012.05.002.

Follieri, M., Magri, D., Sadori, L., 1988. 250,000-year pollen record from Valle di Castiglione (Roma). Pollen et Spores XXX, 329-356.

Heinrich, H., 1988. Origin and Consequences of Cyclic Ice Rafting in the Northern Atlantic Ocean during the Past 130,000 Years. Quaternary Research 29, 142-152.

Hemming, S.R., 2004. Heinrich events: Massive late Pleistocene detritus layers of the North Atlantic and their global climate imprint. Review of Geophysics 42, RG1005, doi:10.1029/2003RG000128.

Huntley, B., Bartlein, P.J., Prentice, I.C., 1989. Climatic control of the distribution and abundance of beech (Fagus L.) in Europe and North America. Journal of Biogeography $16,551-560$.

Gerasimov, I.P. (Ed.), 1964. Atlas Mira. AN SSSR-GUGK SSSR, Moscow (in Russian).

Giesecke, T., Davis, B., Brewer, S., Finsinger, W., Wolters, S., Blaauw, M., de Beaulieu, J.L., Binney, H., Fyfe, R.M., Gaillard, M.-J., Gil-Romera, G., van der Knaap, W.O., Kuneš, P., Kühl, N., van Leeuwen, J.F.N., Leydet, M., Lotter, A.F., Ortu, E., Semmler, M., Bradshaw, R.H.W., 2013. Towards mapping the late Quaternary vegetation change of Europe. Vegetation History and Archaeobotany, doi:10.1007/s00334-012-0390-y.

Gömöry, D., Paule, L., Brus, R., Zhelev, P., Tomović, Z., Gračan, J., 1999. Genetic differenciation and phylogeny of beech on the Balkan peninsula. Journal of Evolutionary Biology 12, 746-754.

Greuter W., Burdet H. M., 1981. Fagus sylvatica ssp. orientalis (Lipsky) Greuter \& Burdet. In: Greuter W., Raus T. (Ed.) Med-Checklist Notulae, 4. Willdenowia 11, 271-280.

Juggins, S., 2003. C2 User Guide. Software for Ecological and Palaeoecological Data Analysis and Visualisation. University of Newcastle, Newcastle upon Tyne.

Klotz, S., Guiot, J., Mosbrugger, V., 2003. Continental European Eemian and early Würmian climate evolution: comparing signals using different quantitative reconstruction approaches based on pollen. Global and Planetary Change 36, 277-294. 
Koreneva, E.V., Kartashova, G.G., 1978. Palynological study of samples from holes 379A, 380A, LEG 42B. In: Ross, D.A., Neprochnov, Y.P., et al. (Eds.) Initial reports of the Deep Sea Drilling Project. U.S. Government Printing Office, Washington, pp. 951-992. Kosarev, A.N., Kostianoy, A.G., 2008. Introduction. In: Kostianoy, G., Kosarev, A.N. (Ed.), The Handbook of Environmental Chemistry: Vol.5, Part Q: The Black Sea Environment. Springer Verlag, Berlin - Heidelberg, pp. 1-10.

Kuprevich, V.F., Ul'yanishchev, V.I., 1975. Opredelitel' rzhavchinnyh gribov SSSR. Nauka i Tehnika, Minsk.

Kürschner, H., Raus, T., Venter, J., 1997. Pflanzen der Türkei: Ägäis - Taurus Inneranatolien. Quelle \& Meyer Verlag, Wiesbaden (in German).

Kwiecien, O., Arz, H.W., Lamy, F., Plessen, B, Bahr, A., Haug, G.H., 2009. North Atlantic control on precipitation pattern in the eastern Mediterranean / Black Sea region during the last glacial. Quaternary Research 71, 375-384.

Lamy, F., Arz, H.W., Bond, G.C., Bahr, A., Pätzold, J., 2006. Multicentennial-scale hydrological changes in the Black Sea and northern Red Sea during the Holocene and the Arctic/North Atlantic Oscillation. Paleoceanography 21, doi: 10.1029/2005PA001184.

Lang, 1994. Quartäre Vegetationsgeschichte Europas. Methode und Ergebnisse. Gustav Fischer Verlag, Jena, Stuttgart, New York (in German).

Magri, Donatella, Vendramin, G.G., Comps, B., Dupanloup, I., Geburek, T., Gömöry, D., Latałowa, M., Litt, T., Paule, L., Roure, J.M., Tantau, I., van der Knaap, W.O., Petit, R.J., de Beaulieu, J.-L., 2006. A new scenario for the Quaternary history of European beech populations: palaeobotanical evidence and genetic consequences. New Phytologist 171, 199-221.

Mayer, H., Aksoy, H., 1986. Wälder der Türkei. Gustav Fischer Verlag, Stuttgart-New York (in German).

Meusel, H., Jäger, E.J., 1989. Ecogeographical differentiation of the Submediterranean deciduous forest flora. Plant Systematics and Evolution 162, 315-329.

Müller, U.C., Kukla, G.J., 2004. North Atlantic Current and European environments during the declining stage of the last interglacial. Geology 32, 1009-1012.

Neprochnov, Yu.P. (Ed.), 1980. Geologicheskaya istoriya Chernogo moria po resul'tatam glubokovodnogo bureniya. Nauka, Moscow (in Russian). 
Nowaczyk, N.R., Arz, H.W., Frank, U., Kind, J., Plessen, B., 2012. Dynamics of the Laschamp geomagnetic excursion from the Black Sea sediments. Earth and Planetary Science Letters 351-352, 54-69.

Oguz, T., Latun, V.S., Latif, M.A., Vladimirov, V.V., Sur, H.I., Markov, A.A., Özsoy, E., Kotovshchikov, B.B., Eremeev, V.V., Ünlüata, Ü., 1993. Circulation in the surface and intermediate layers of the Black Sea. Deep-Sea Research 40, 1597-1612.

Otto-Bliesner, B.L., Marshall, S.J., Overpeck, J.T., Miller, G.H., Hu, A., CAPE Last Interglacial Project members, 2006. Simulating Arctic Climate Warmth and Icefield Retreat in the Last Interglaciation. Science 311, 1751-1753.

Özsoy, E., Ünlüata, Ü., 1997. Oceanography of the Black Sea: a review of some recent results. Earth-Science Reviews 42, 231-272.

Papageorgiou, A.C., Vidalis, A., Gailing, O., Tsiripidis, I., Hatziskakis, S., Boutsios, S., Galatsidas, S., Finkeldey, R., 2008. Genetic variation of beech (Fagus sylvatica L.) in Rodopi (N.E. Greece). European Journal of Forest Research 127, 81-88.

Pospelova, V., Pedersen, T.F., de Vernal, A., 2006. Dinoflagellate cysts as indicators of climatic and oceanographic changes during the past $40 \mathrm{kyr}$ in the Santa Barbara Basin, southern California. Paleoceanography 21, PA2010, doi:10.1029/2005PA001251.

Prentice, I.C., Guiot, J., Huntley, B., Jolly, D., Cheddadi, R., 1996. Reconstructing biomes from palaecological data: a general method and its application to European pollen data at 0 and 6 ka. Climate Dynamics 12, 185-194.

Reille, M., Andrieu, V., de Beaulieu, J.-L., Guenet, P., Goeury, C., 1998. A long pollen record from Lac du Bouchet, massif Central, France: for the period ca. 325 to $100 \mathrm{ka} \mathrm{BP}$ (OIS 9c to OIS 5e). Quaternary Science Review 17, 1107-1123.

Richter, T.O., Van der Gaast, S., Koster, B., Vaars, A., Gieles, R., de Stigter, H.C., de Haas, H., van Weering, T.C.E., 2006. The Avaatech XRF Core Scanner: Technical description and applications to NE Atlantic sediments, in: Rothwell, G. (Ed.), New Techniques in Sediment Core Analysis, 267. Geological Society Special Publications, London, 39-50.

Rohling, E.J., Grant, K., Hemleben, Ch., Siddal, M., Hoogakker, B.A.A., Bolshaw, M., Kucera, M., 2007. High rates of sea-level rise during the last interglacial period. Nature Geoscience 1, 38-42.

Ross, D.A., Neprochnov, Y.P. et al. (Eds.), 1978. Initial Reports of the Deep Sea Drilling Project. Volume 42, part 2, U.S. Government Printing Office, Washington. 
Sánchez Goñi, M.F., Eynaud, F., Turon, J.L., Shackleton, N.J., 1999. High resolution palynological record off the Iberian margin: direct land-sea correlation for the Last Interglacial complex. Earth and Planetary Science Letters171, 123-137.

Sánchez Goñi, M.F., Loutre, M.F., Crucifix, M., Peyron, O., Santos, L., Duprat, J., Malaizé, B., Turon, J.-L., Peypouquet, J.-P., 2005. Increasing vegetation and climate gradient in Western Europe over the Last Glacial Inception (122-110): data-model comparison. Earth and Planetary Science Letters 231, 111-130.

Seidenkrantz, M.-S., Bornmalm, L., Johnsen, S.J., Knudsen, K.L., Kuijpers, A., Lauritzen, S.E., Leroy, S.A.G., Mergeai, I., Schweger, C., van Vliet-Lanoë, B., 1996. Two-step deglaciation at the oxygen isotope stage 6/5e transition: the Zeifen-Kattegat climate oscillation. Quaternary Science Reviews 15, 63-75.

Shackleton, N.J., Sánchez-Goñi, M.F., Pailler, D., Lancelot, Y., 2003. Marine Isotope Stage 5e and the Eemian Interglacial. Global and Planetary Change 36, 151-155.

Shatilova, I.I., 1974. Palinologicheskoe obosnovanie geokhronologii verhnego Pliotsena i Pleistotsena zapadnoy Gruzii. Metsniereba, Tbilisi (in Russian).

Shumilovskikh, L.S., Tarasov, P., Arz, H.W., Fleitmann, D., Marret, F., Nowaczyk, N., Plessen, B., Schlütz, F., Behling, H., 2012. Vegetation and environmental dynamics in the southern Black Sea region since 18 kyr BP derived from the marine core 22-GC3. Palaeogeography, Palaeoclimatology, Palaeoecology 337-338, 177-193.

Shumilovskikh, L.S., Marret, F., Fleitmann, D., Arz, H.W., Nowaczyk, N., Behling, H., 2013. Eemian and Holocene sea-surface conditions in the southern Black Sea: organic-walled dinoflagellate cyst record from core 22-GC3. Marine Micropaleontology 101, 146-160.

Spiridonova, E.A., 1991. Evolutsia rastitel'nogo pokrova basseyna Dona v verhnem Pleistocene-Holocene. Nauka, Moscow (in Russian).

Turner, C., 2000. The Eemian interglacial in the North European plain and adjacent areas. Geologie en Mijnbouw 79, 217-231.

Türkeş, M., Sümer, U.M., Kiliç, G., 1996. Observed changes in maximum and minimum temperatures in Turkey. International Journal of Climatology 16, 463-477.

Tzedakis, P.C., 1999. The last climatic cycle at Kopais, central Greece. Journal of the Geological Society 156, 425-434.

Tzedakis, P.C., 2000. Vegatation variability in Greece during the last interglacial. Geologie en Mijnbouw 79, 355-367.

Tzedakis, P.C., Bennett, K.D., 1995. Interglacial vegetation succession: a view from southern Europe. Quaternary Science Reviews 14, 967-982. 
Tzedakis, P.C., Frogley, M.R., Heaton, T.H.E., 2003. Last Interglacial conditions in southern Europe: evidence from Ioannina, northwest Greece. Global and Planetary Change 36, 157-170.

Van Geel, B., Buurman, J., Brinkkemper, O., Schelvis, J, Aptroot, A., Reenen, G. van, Hakbijl, T., 2003. Environmental reconstructions of a Roman Period settlement site in Uitgeest (the Netherlands), with special reference to coprophilous fungi. Journal of Archaeological Science 30, 873-884.

Vánky, K., 1994. European Smut Fungi. Gustav Fischer Verlag, Stuttgart, Jena, New York.

Wijmstra, T.A., 1969. Palynology of the first 30 meters of a 120 m deep section in Northern Greece. Acta Botanica Neerlandica 18, 511-527.

Woillard, G. M., 1978. Grande Pile Peat Bog: A Continuous Pollen Record for the Last 140,000 Years. Quaternary Research 9, 1-21.

Yanko-Hombach, V.V., Gilbert, A.S., Panin, N., Dolukhanov, P.M. (Eds.), 2007. The Black Sea Flood Question: Changes in Coastline, Climate and Human Settlement. Springer, Dordrecht.

Zohary, M., 1973. Geobotanical foundations of the Middle East. Fischer, Stuttgart, Amsterdam. 


\section{MANUSCRIPT 4}

\section{Millennial-scale environmental variability during the last glacial detected in pollen and dinocyst records from the SE Black Sea}

Lyudmila S. Shumilovskikh ${ }^{\mathrm{a}}$, Helge W. Arz ${ }^{\mathrm{b}}$, Norbert Nowaczyk ${ }^{\mathrm{c}}$, Dominik Fleitmann ${ }^{\mathrm{d}, \mathrm{e}}$, Antje Wegwerth $^{\mathrm{b}}$, Hermann Behling $^{\mathrm{a}}$

a Department of Palynology and Climate Dynamics, University of Göttingen, Untere Karspüle 2, 37073 Göttingen, Germany

b Leibniz Institute for Baltic Sea Research Warnemuende, Seestrasse 15, 18119 RostockWarnemuende, Germany

c Helmholtz Center Potsdam GFZ German Research Centre for Geosciences, Telegrafenberg, 14473 Potsdam, Germany

d Department of Archaeology, School of Human and Environmental Sciences, University of Reading, Whiteknights, PO Box 227, Reading RG6 6AB, United Kingdom.

e Institute of Geological Sciences and Oeschger Centre for Climate Change Research, University of Bern, Baltzerstrasse 3, 3012 Bern, Switzerland

Supposed to be submitted to Climate of the Past 


\begin{abstract}
High-resolution pollen and dinoflagellate cyst records from marine sediment core 25$\mathrm{GC1}$, covering 64-25 ka BP, were used to reconstruct vegetation dynamics in Northern Anatolia and surface conditions of the Black Sea during the last glacial. The dominance of Artemisia in the pollen record indicates a steppe landscape and arid conditions, whereas the presence of temperate and warm-temperate arboreal pollen suggests glacial refugia in Northern Anatolia. A general cooling trend towards $25 \mathrm{ka}$ BP is evident by the decrease of Quercus and increase of Pinus. Climatic oscillations known as Dansgaard-Oeschger (D-O) events from Greenland ice-core records are clearly reflected by an increase of temperate tree pollen, mainly of Quercus, indicating a spread of oak forests due to warm and wet conditions during the D-O interstadials. The dinocyst record reflects brackish conditions in the Black Sea during the last glacial, indicated by Pyxidinopsis psilata and Spiniferites cruciformis. The decrease of marine indicators (marine dinocysts, acritachs) and the increase of freshwater algae (Pediastrum, Botryococcus) from the bottom to the top of the core indicate freshening of surface water towards $25 \mathrm{ka}$ BP. D-O interstadials are indicated by high dinocyst concentrations reflecting an increase of primary productivity. Heinrich events show a similar impact on the environment in Northern Anatolia/Black Sea region as Dansgaard-Oeschger stadials.
\end{abstract}

Key-words: pollen, dinoflagellate cysts, Dansgaard-Oeschger events, Heinrich events, marine isotope stadium 3 


\section{Introduction}

The climatic conditions during the last glacial are characterized by several dramatic and rapid alternations of cold and warm intervals, detected in Greenland ice cores (Dansgaard et al., 1993; Grootes et al., 1993) and known as Dansgaard-Oeschger (D-O) stadials and interstadials, respectively. Although the triggers and mechanisms of these changes are still under discussion (Kudrass et al., 2001; Rahmstorf, 2002), the impact of the D-O events on the environment and vegetation of the western Mediterranean region have been documented by marine records from the Atlantic (Sánchez-Goñi et al., 2000), Alboran Sea (Sánchez-Goñi et al., 2002) and by high-resolution terrestrial pollen records (see review by Fletcher et al., 2010). Pollen records revealed a clear response of vegetation to D-O events: steppe landscapes characterized stadials and temperate, mainly oak, forest developments were typical for interstadials (Fletcher et al., 2010). During D-O stadials the ice sheet became instable and huge ice blocks drifted and brought ice-rafted detritus (IRD) southwards (Bond and Lotti, 1995). The most extreme of these cold intervals, Heinrich events (HE) (Heinrich, 1988; Bond et al., 1993), are characterised by low sea-surface temperatures (SST) and reduced sea-surface salinity (SSS) of Northern Atlantic (Rahmstorf, 2002; Hemming, 2004). The effect of HE on the vegetation is contradictory, as several pollen records support an impact (e.g. Margari et al., 2009), whereas others do not (e.g. Sánchez Goñi et al., 2002). In addressing such large scale and contentious questions, the advantage of multidisciplinary studies on marine sediments is that they provide combined terrestrial-marine sequences, permitting land-sea correlations in situ (Roucoux et al., 2005).

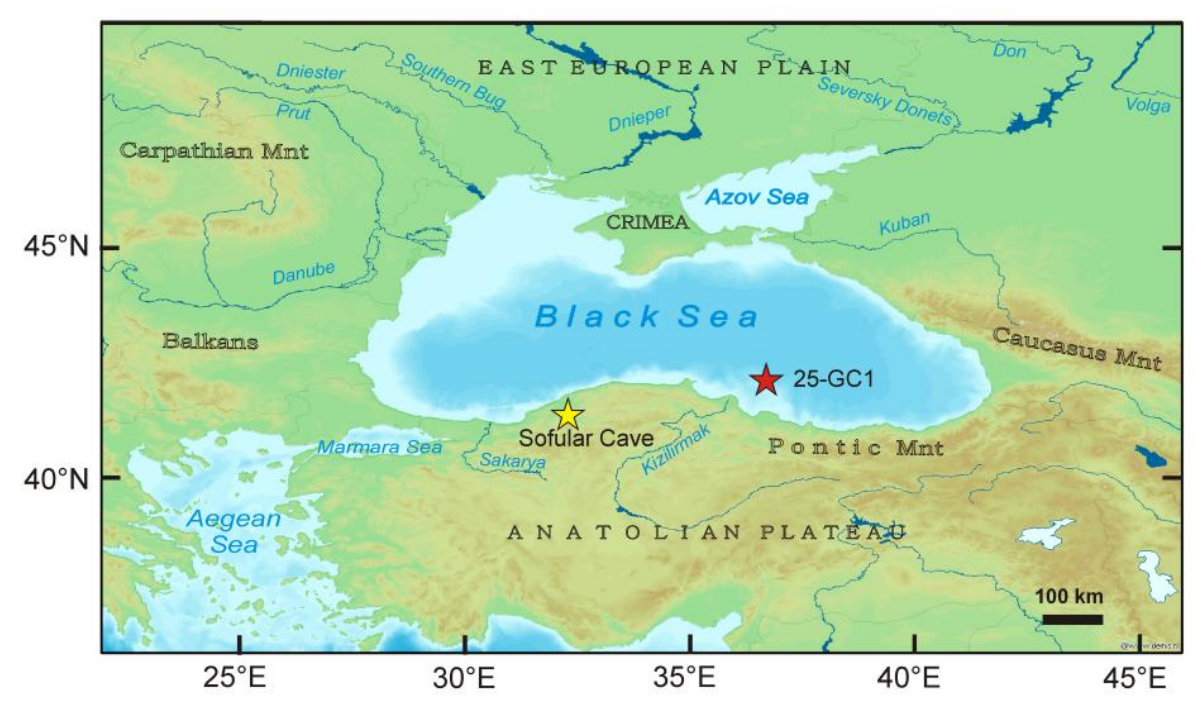

Fig. 1. Map of the Black Sea region with location of the core 25-GC1 and the Sofular cave. Map was drawn with Quantum GIS (1.7.0) by using data from www.bgr.de, www.nowcoast.noaa.gov, www2.demis.nl. 
In comparison to the western Mediterranean, the environmental impact of millennialscale climatic instability during the last glacial is less well known in the eastern Mediterranean region (Fletcher et al., 2010). The high-resolution pollen records from Tenaghi Philippon (Greece) reveal high sensitivity and rapid response of vegetation to climatic changes during the D-O events (Müller et al., 2011). In contrast, high-resolution and precisely dated stalagmite oxygen and carbon isotope records from the Sofular Cave in northwestern Turkey demonstrate a rapid ecosystem response to D-O and Heinrich events, and suggest a phase lag of up to several hundred years between climate and vegetation (Fleitmann et al., 2009).

In this study we present the first continuous pollen and algal records from the SE Black Sea during the glacial interval 63-25 ka BP. Within this work we address the question of how the vegetation of Northern Anatolia and surface conditions of the Black Sea react to the millennial scale climate variability during the last glacial.

\section{Geographical characteristics of the core site}

Today, the Black Sea is the largest anoxic basin on the Earth. The upper 200 m water layer is oxygenated with a salinity of $17-18 \%$, whereas the water layer below $200 \mathrm{~m}$ is anoxic with a salinity of $\sim 22 \%$ (Özsoy and Ünlüata, 1997). Such a characteristic vertical structure of the Black Sea is caused by the interruption of vertical water circulation through different densities of upper and lower water layers. The upper layer receives freshwater input from rivers and precipitation and therefore is less dense than the deeper layer, influenced by inflow of saline ( $37 \%$ ) Mediterranean water through Bosporus (Kosarev and Kostianoy, 2008).

The northwestern slopes of the Pontus Mountains receive precipitation from the Black Sea and therefore are covered by temperate forests. In altitudes between 0-800 m Fagus orientalis associates with various deciduous trees such as Carpinus betulus, Castanea sativa, Tilia rubra, Corylus, deciduous Quercus species etc. with evergreen shrubs (Rhododendron ponticum, Ilex aquifolium, I. colchica, Daphne pontica, Buxus sempervirens, Prunus laurocerasus) and lianas (Smilax, Hedera, Clematis, Vitis) (Zohary, 1973; Mayer and Aksoy, 1986). However, scattered Mediterranean trees or shrubs (Phillyrea media, Laurus nobilis, Cistus creticus, J. oxycedrus, Erica arborea, Myrthus communis, Arbutus andrachne) can be found in warm and dry habitats along the Black Sea coast. At higher elevations ( 800-1500 $\mathrm{m})$, pure beech (F. orientalis) or hornbeam-beech (Carpinus-Fagus) forests predominate. Relatively low mountains (below $1500 \mathrm{~m}$ ) explain the dominance of pure Fagus forests and the absence of Abies in the central part of the Northern Anatolia, whereas Abies dominate in 
western and Picea in eastern Pontus Mountains. Grasslands dominate in the subalpine and alpine mountain belt above $\sim 2000 \mathrm{~m}$ elevation. The southeastern mountain slopes facing the Anatolian Plateau lie in the rain shadow and are therefore covered with drier vegetation types, including open woodland dominated by eurythermic conifers (Pinus nigra, Juniperus excelsa, $J$. oxycedrus) and deciduous oaks (Quercus pubescens, Q. trojana). At the border between forest steppe and steppe, oaks and junipers grow. Above $2000 \mathrm{~m}$ elevation subalpine thorny shrubs (Astracanthus spec., Sarcopoterium spec.) are characteristic (Zohary, 1973; Mayer and Aksoy, 1986).

\section{Material and methods}

The sediment core $25-\mathrm{GC} 1\left(42^{\circ} 06.2^{\prime} \mathrm{N} / 36^{\circ} 37.4^{\prime} \mathrm{E}\right.$; $418 \mathrm{~m}$ water depth) was collected in the SE Black Sea (Fig. 1) during cruise M 72/5 of the RV Meteor in 2007.

\section{Chronological framework}

Details of the construction of the age-depth model for core 25-GC1 are described by Nowaczyk et al. (2012) and presented here briefly. Tephra layers, radiocarbon ages and palaeomagnetic Laschamp Event provide independent controls for the development of a chronological framework (Fig. 2). Tuning to NGRIP oxygen isotope record GICC05 was carried out by the computer software xtc by simultaneous synchronization and interactive wiggle-matching routine of climate-related variations in the Black Sea records such as lognormalised IRD abundances, carbonate content, Ca XRF-counts, and high-resolution magnetic susceptibility (Fig. 2).

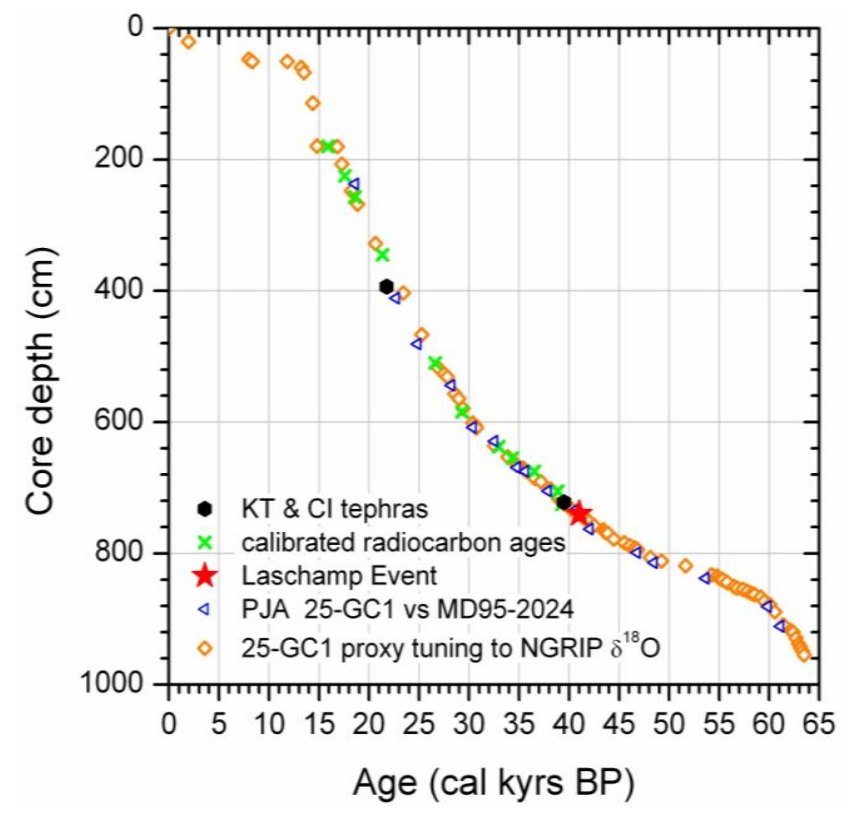

Fig. 2. Stratigraphical framework for core $25-\mathrm{GC} 1$. 


\section{Palynological investigation}

In total, 152 subsamples of $1 \mathrm{~cm}^{3}$ of wet sediment were taken along the core and prepared using standard methods (Erdtman, 1960; Moore et al., 1999), including cold 10\% $\mathrm{HCl}$, cold 71-74\% HF over two nights, acetolysis (three minutes) and final cleaning with an ultrasonic bath (nylon sieve of 1-2 $\mu \mathrm{m}$ mesh size). In order to calculate pollen concentrations (Stockmarr, 1971), one or two tablets of Lycopodium spores (Batch No 177745, consist of $18584 \pm 354$ spores) were added to each sample. We followed the pollen and spore nomenclature of Beug (2004) and Chester and Raine (2001). Pollen sum for calculation of pollen and spores percentages include a minimum of 300-350 identified counted pollen grains per sample. In order to compare the pollen record 25-GC1 for a general overview of European pollen records of Fletcher et al. (2010), we grouped pollen spectra to biomes following classification of these authors.

In order to evaluate sea-surface conditions, dinoflagellate cysts (dinocysts), green algae (Pediastrum, Botryococcus, Zygnemataceae) and acritarchs (Cymatiosphaera, Micrhystridium) were counted on the residues prepared for palynological analyses. Due to the possible damage of cysts by acetolysis and therefore altered percentages of species in assemblages, we present record of dinocyst concentrations. Freshwater/brackish species include Pyxidinopsis psilata, Spiniferites cruciformis and Caspidinium rugosum, marine species - Lingulodinium machaerophorum, Operculodinium centrocarpum, Tuberculodinium vancampoae, Tectatodinium pellitum, Bitectatodinium tepikiense, Penthapharsodinium dalei, Spiniferites pachydermis, Spiniferites ssp.

The diagrams (Figs. 3, 4 and 5) were constructed using the software C2 (version 1.6.6) (Juggins, 2003).

\section{Results}

Pollen (Fig. 3) and algae (Fig. 4) data are presented in age-scale. Grey bars indicate D-O interstadials as indicated by $\mathrm{CaCO}_{3}$ and IRD records (Fig. 5).

\section{Pollen record}

Arboreal pollen percentages vary between 5.7 and 46.7, indicating variable climatic conditions during the glacial period. The pollen concentration vary between 1.6 and 13-17 $\mathrm{x} 10^{3}$ grains $/ \mathrm{cm}^{3}$, showing plateau during $57-37 \mathrm{ka} \mathrm{BP}$ and a decreasing trend towards $25 \mathrm{ka}$ 
BP. General trends of vegetation changes is shown by an increase in eurythermic and grassland/dry shrubland biomes and decrease in xerophytic biomes.

During the D-O interstadials, arboreal and temperate biome pollen increase up to 15$47 \%$ and 10-16\%, respectively (Fig. 3). The most indicative taxon is the Quercus robur-type, which reaches $4-12 \%$ and 100-1000 grains $/ \mathrm{cm}^{3}$. The general proportion of Pinus diploxylontype increases towards $25 \mathrm{ka} \mathrm{BP}$. The correlation of pine percentages to D-O warming is more pronounced since D-O 8 and reach maxima of 14-24\%, whereas concentration maxima (up to 1.3 grains $/ \mathrm{cm}^{3}$ ) occur during D-O 14 to 12 .

D-O stadials are indicated by an increase in non-arboreal pollen (NAP) percentages up to $94 \%$ (Fig. 3), mainly by Artemisia and Chenopodiaceae. The latter show a clear response of xerophytic biomes (Fig. 3).

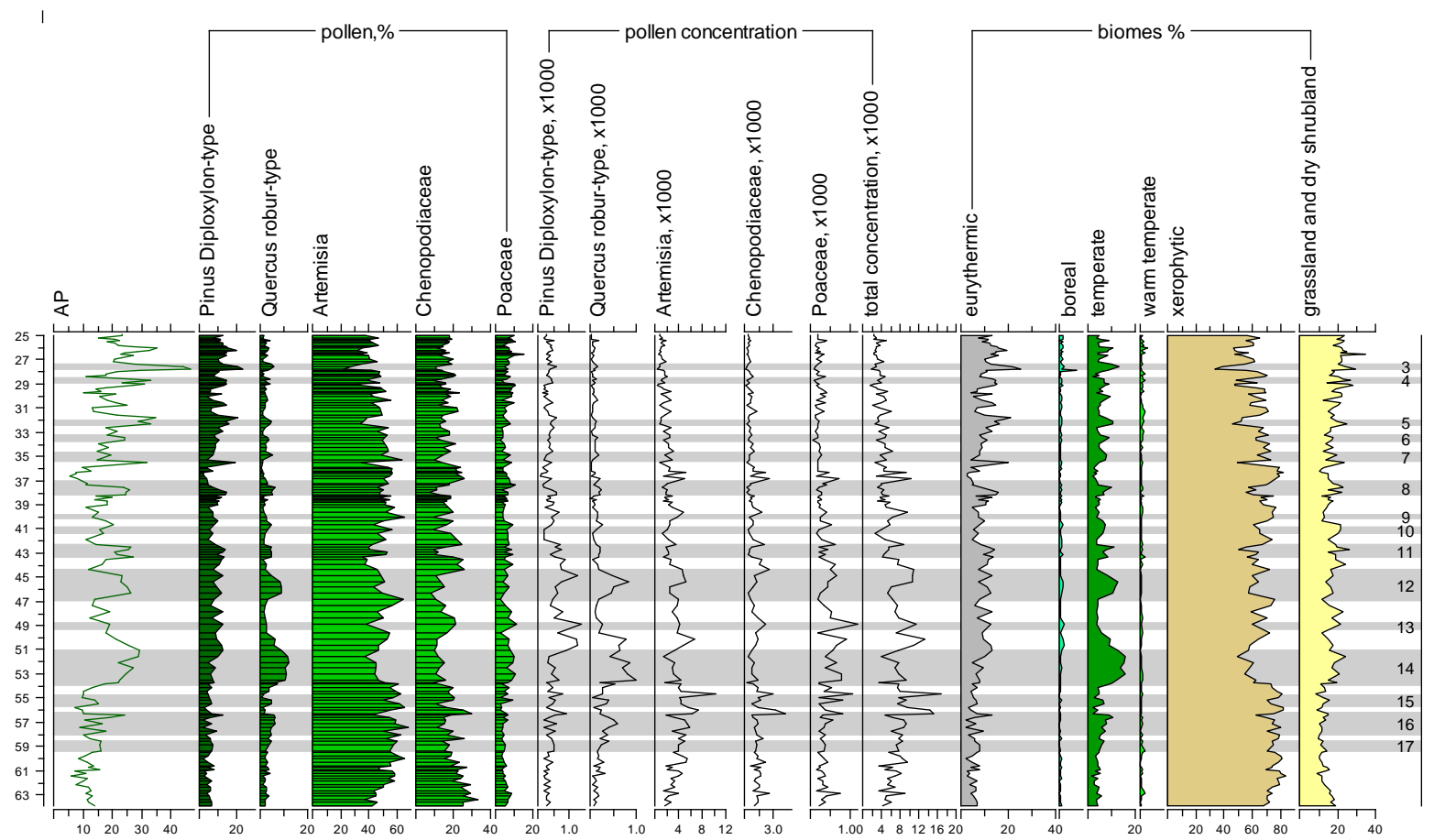

Fig. 3. Percentage and concentration $\left(\right.$ grains $/ \mathrm{cm}^{3}$ ) diagram of main pollen taxa and percentages of biomes, grouped following Fletcher et al. (2010).

Sea-surface records

Algal remains (Fig. 4) are presented mainly by dinocysts, reaching 11-14 cysts $/ \mathrm{cm}^{3}$, with the main contribution of freshwater/brackish species Pyxidinopsis psilata and Spiniferites cruciformis. Dinocyst concentration is very low $\left(0-400 \mathrm{cyst} / \mathrm{cm}^{3}\right)$ during D-O stadials and relatively high $\left(1,300-14,000 \mathrm{cyst} / \mathrm{cm}^{3}\right)$ during the D-O interstadials. 


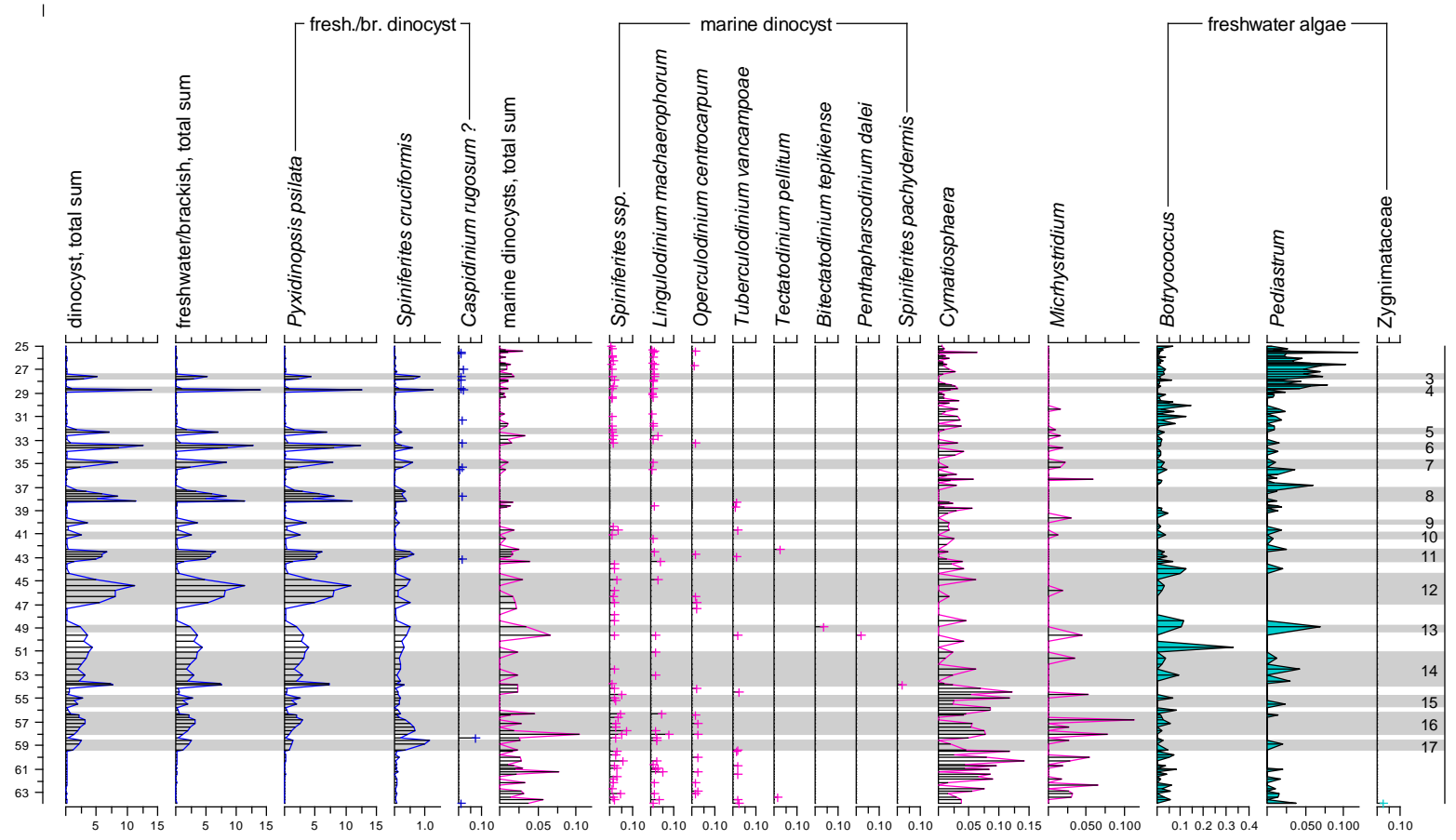

Fig. 4. Concentration of dinoflagellate cysts, algae and acritarchs (per $\mathrm{cm}^{3}$ of sediment, $\mathrm{x} 1000)$.

Several marine dinocyst species occasionally occur in the record such as Lingulodinium machaerophorum, Operculodinium centrocarpum, Spiniferites ssp., Tuberculodinium vancampoae, Tectatodinium pellitum, Bitectatodinium tepikiense, Spiniferites pachydermis (Fig. 4). The record shows fluctuating intervals of occurrence and absence of marine species with a clear trend of decrease in marine species concentration towards $25 \mathrm{ka} \mathrm{BP}$, similar to marine acritarchs Cymatiosphaera and Micrhystridium.

Freshwater algae Pediastrum, Botryococcus also have maxima or absence in fluctuating intervals, which correlates negative to marine dinocyst species concentrations (Fig. 4). The stable occurrence of sum of freshwater algae (Fig. 5) in the sediment begins after D-O 5 at $\sim 32 \mathrm{ka} \mathrm{BP}$ and Pediastrum concentrations (Fig. 4 and 5) increase towards $25 \mathrm{ka}$ BP significantly.

\section{Discussion}

\section{Long-term patterns in Northern Anatolian vegetation changes during 64-25 ka BP}

Based on the pollen record 25-GC1, gradual decrease in temperate Quercus and increase in eurythermic Pinus indicates a general cooling trend in Northern Anatolia towards $25 \mathrm{ka}$ BP (Fig. 5). The suggested cooling in Northern Anatolia is also supported by IRD records from core 25-GC1 (Fig. 5). Occurrence of IRD indicates transport of grains by coastal 
ice, formed during cold winter periods (Nowachyk et al., 2012). Concentrations of IRD in 25$\mathrm{GC1}$ increase from bottom to the top, indicating more often occurrence of cold winters (Fig. 5). Similar to other European pollen records (Fletcher et al., 2010), our reconstructions correlate well with the increase in Northern hemisphere ice volume towards MIS 2.

Comparing pollen data at the end of MIS 4 ( 64-60 ka BP) with the data at the beginning of MIS 2 ( 28-25 ka BP) shows that during 64-60 ka BP, AP values did not exceed 13-15\%, suggesting very arid conditions. During 28-25 ka BP values of AP never decrease below $13 \%$, suggesting rather cold but wet conditions in comparison to MIS 4. The decrease in aridity is also supported by the decreasing role of xerophytic biomes and increase in grassland and dry shrubland (Fig. 3).

\section{Northern Anatolian vegetation and abrupt climate changes during the last glacial}

Changes in the pollen spectra of the 25-GC1 record clearly reflect the impacts of D-O events on the vegetation in Northern Anatolia (Fig. 3, 5). During D-O interstadials, increases in Quercus robur-type percentages and concentrations as well as in temperate biomes percentages (Fig. 3), suggest a spreading of temperate forests dominated by oaks in Northern Anatolia due to an onset of humid conditions. Thereby, a pronounced increase in Quercus percentages is characteristic for each particular D-O event, except for 17-16 and 10-9, which show interstadial conditions but could not be separated. D-O 13 is not reflected by Quercus, but well by the AP curve (Fig. 5).

Cold D-O stadials are reflected by an increase in NAP, mainly by Chenopodiaceae and partly by Artemisia. The xerophytic biomes indicate arid conditions in Northern Anatolia. Cold winters during the D-O stadials are suggested from maxima in IRD records (Fig. 5). The fact that NAP percentage maxima correspond to IRD maxima (Fig. 5) raises the question of whether pollen could be physically transported by ice, changing pollen spectra. However, absence of close correlations between IRD and pollen concentrations (Fig. 5) does not support this hypothesis. Therefore, NAP and IRD maxima are likely caused by the same trigger, namely low winter temperatures.

The most pronounced D-O interstadials 14 and 12 provide the unique function of correlating vegetation and Black Sea surface records from 25-GC1 to temperature increase, indicated by the NGRIP oxygen isotope record (Fig. 5). The pollen record demonstrates synchronous increase of oak and temperate biome percentages with an increase in dinocyst concentration together with the onset of warm conditions. However, oak percentages reach their maxima $\sim 500 \mathrm{yr}$ later than the start of warming, indicating vegetation development 
during this interval as a response to increased temperature/precipitation. Similar trends are documented by pollen records from the western Mediterranean region (Roucoux et al., 2005). For Northern Anatolia, in the So- $1 \delta^{13} \mathrm{C}$ time series, the negative shifts of 1-3\% indicate a transition into interglacial occurring within $252 \pm 87$ years, slower than $121 \pm 99$ and $62 \pm 14$ years in the So- $1 \delta^{18} \mathrm{O}$ record and NGRIP, respectively (Fleitmann et al., 2009). Based on these data, the authors suggest "that the ecosystem reached a kind of equilibrium with climate within $\sim 250$ years" (Fleitmann et al., 2009). These lags can possibly be explained considering ice sheet-atmospheric circulation dynamic. Although reasons for the D-O interstadial are still unknown, climate warming, indicated by $\delta^{18} \mathrm{O}$ isotope record from Greenland ice-cores (Dansgaard et al., 1993; Grootes et al., 1993), imply ice-sheet melting and reorganisation of atmospheric circulation such as northward migration of the summer position of the westerlies. These processes were triggered by high temperatures at the beginning of the interglacial and apparently continued several hundred years, causing "lags" in terrestrial responses.

In accordance to $\delta^{13} \mathrm{C}$ and $\delta^{18} \mathrm{O}$ isotope records from Sofular Cave (Fleitmann et al., 2009), the multi-proxy records from sediment core 25-GC1 demonstrate that HEs and D-O stadials were similarly severe (Fig. 5). Moreover, the most severe cooling is suggested from pollen record 25-GC1 after D-O 8, when AP reach the lowest values of $\sim 6 \%$ and spectra are dominated by xerophytic Artemisia and Chenopodiaceae (Fig. 3).

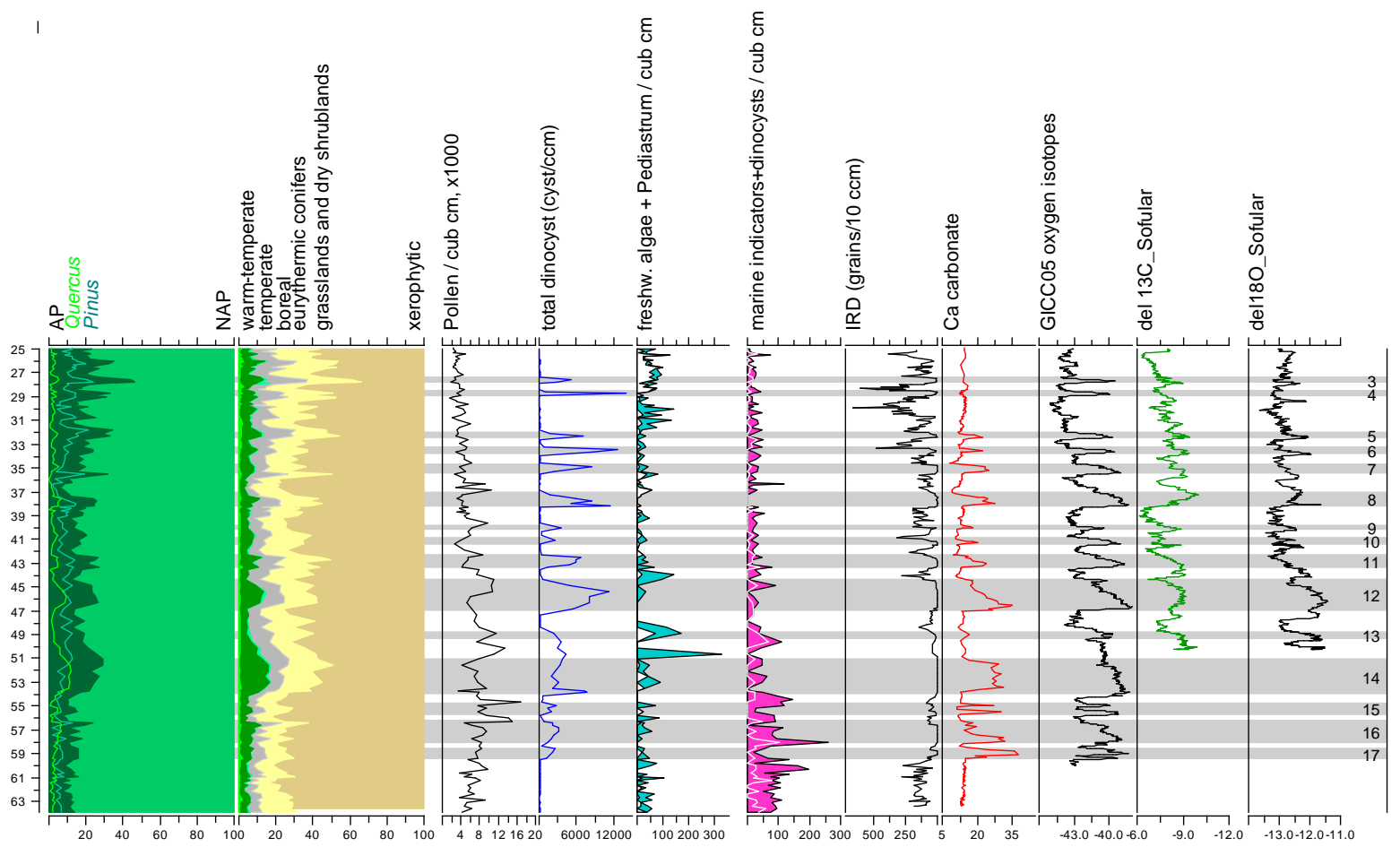

Fig. 5. Summary plot for the Black Sea vegetation and sea-surface records in comparison $\delta^{13} \mathrm{C}$ and $\delta^{18} \mathrm{O}$ isotope records from Sofular cave and to NGRIP ice-core $\delta^{18} \mathrm{O}$ isotope record. 
Long-term patterns in Black Sea surface conditions during 64-25 ka BP

Generally, the dinocyst record reveals freshwater/brackish conditions with a salinity of $\sim 0-12 \%$ in the Black Sea during the last glacial, indicated by dominance of Pyxidinopsis psilata, occurring in the Baltic Sea (Yu and Berglund, 2007), and Spiniferites cruciformis, known from the Caspian Sea (Marret et al., 2004) and modern freshwater lakes in Greece (Kouli et al., 2001) and Turkey (Leroy and Albay, 2010). During the glacial periods, the global sea-level decreased, breaking the Mediterranean inflow through Bosporus. This change in the hydrological balance of the Black Sea led to a freshening of the water body (Ross et al., 1978; Neprochnov, 1980; Svitoch, 2008). Freshwater/brackish conditions were reconstructed for the end of the last glacial (e.g. Wall et al., 1973; Mudie et al., 2004; Atanassova, 2005; Bahr et al., 2006; Buynevich et al., 2011; Filipova-Marinova et al., 2012) and at the end of the penultimate glacial (Shumilovskikh et al., in review).

The appearance of tropical/subtropical species Tuberculodinium vancampoae, and fully marine indicators Spiniferites pachydermis, Bitectatodinium tepikiense, Tectatodinium pellitum during the glacial brackish phase of the Black Sea (Fig. 4) is a striking feature of the record. These species entered the Black Sea basin during the Mediterranean transgression at the beginning of the Eemian and were abundant between 126.5-121 ka BP, indicating subtropical temperatures and sea-surface salinity at 28-30 \%o (Shumilovskikh et al., in review). During 121-119 ka BP, the occurrence of these species in spectra decrease, indicating cooling and freshening. There are no records of surface conditions of the Black Sea between 119 and $64 \mathrm{ka} \mathrm{BP,} \mathrm{making} \mathrm{multiple} \mathrm{entries} \mathrm{of} \mathrm{the} \mathrm{species} \mathrm{possible.} \mathrm{The} \mathrm{occurrence} \mathrm{of}$ subtropical and fully marine species during 64-25 ka BP prompt a new question, namely whether Mediterranean water could enter the Black Sea during the last glacial, making new dinoflagellate invasions possible, or if these dinoflagellates are remains that had survived since the last interglacial. In any case, presence of these species during the freshwater/brackish phase of the Black Sea is interesting in two respects. On the one hand, they suggest SSS in the Black Sea at the maximum limit of Pyxidinopsis psitata, possibly 12$15 \%$. On the other hand, it could indicate a broader tolerance of these species than it is suggested by modern distribution maps (Marret and Zonneveld, 2004).

Concentrations of marine species and freshwater algae show opposite trends in the core. Concentrations of marine dinocysts and acritarchs (Cymatiosphaera and Micrhystridium) decrease from 30-100 at the bottom to 6-30 cyst $/ \mathrm{cm}^{3}$ at the top of the core, whereas freshwater algae occur more often and concentrations of the obligate freshwater genus Pediastrum increase to the top of the core (Fig. 4, 5). Such tendencies strongly suggest a decrease in SSS 
of the Black Sea towards $25 \mathrm{ka} \mathrm{BP}$, indicating that freshening of the Black Sea was a continuous process during the last glacial.

The Black Sea surface conditions and abrupt climate changes during the last glacial

In core 25-GC1, high concentrations of freshwater/brackish dinocysts Pyxidinopsis psilata and Spiniferites cruciformis correlate well to the high $\mathrm{CaCO}_{3}$ concentrations (Fig. 5), implying enhanced productivity during warm D-O interstadials. The enhanced primary productivity in western Mediterranean Sea during the D-O interstadials was documented by geochemical proxies (Moreno et al., 2004). Increases in dinocyst accumulation rates during D-O interstadials were already documented for Santa Barbara Basin in southern California (Pospelova et al., 2006) demonstrating sensitivity of dinocysts to the temperature increase. Authigenic calcium carbonate precipitation occurs as a product of phytoplankton blooms during warm periods through $\mathrm{CO}_{2}$ depletion and pH-increase in lakes (Bahr et al., 2005). Dinocyst concentrations increase during each individual warm interval, including D-O 4 and 3, which are not indicated by $\mathrm{Ca}$ carbonates. They furthermore do not show interruptions between D-O 14 and 13 like $\mathrm{CaCO}_{3}$ (Fig. 5), indicating a different sensitivity of calcium carbonate precipitation and dinocyst concentration records to temperature. $\delta^{18} \mathrm{O}$ record from ice-core GICC05 shows relatively high Greenland temperatures between D-O 14 and 13. If the same was true for the Black Sea region, dinocysts show a lower temperature threshold level than $\mathrm{Ca}$ carbonates, which are a more sensitive record of temperature decrease (Shumilovskikh et al., 2012).

Freshwater algae and marine dinocysts do not show clear correlation to D-O events. Moreover, their maxima tend to occur in opposite modes and rarely occur at the same time through the record (Fig. 5).

\section{Conclusions}

1. Multi-proxy records from the marine core 25-GC1 demonstrate that the Black Sea/Northern Anatolian region is a highly sensitive area for millennial scale climate variability.

2. D-O interstadials are characterised by spreading of temperate forests, clearly reflected by high values of Quercus, and by enhanced primary productivity, indicated by increased concentrations of dinocyst and calcium carbonates.

3. The maximum of Quercus in the most pronounced interstadials 14 and 12 occurs $\sim 500$ years later from the onset of warming. 
4. D-O stadials are characterized by low primary productivity in the Black Sea and spread of xerophytic vegetation in Northern Anatolia, indicating cold climatic conditions. The impact of cold HEs and D-O stadials are similar.

5. Long-term vegetation changes during 64-25 ka BP and the IRD record suggest a decrease in temperatures towards MIS 2, indicated by the decreasing role of Quercus and increasing role of Pinus, correlating with an increase in IRD concentrations. Therefore, the end of MIS 4 was apparently more arid than the beginning of MIS 2.

6. The increase in concentrations of freshwater algae and decrease in concentrations of marine dinocysts and acritarchs suggest a lowering of the Black Sea surface salinity towards MIS 2.

\section{Acknowledgements}

We thank Laura Sutcliffe for polishing the English and the captain and crew of RV Meteor for their support and contribution to the overall success of the M72/5 Black Sea research cruise in 2007. This work is financially supported by the Deutsche Forschungsgemeinschaft (DFG) within the SPP 1266 "INTERDYNAMIC".

\section{References}

Atanassova, J., 2005. Palaeoecological setting of the western Black Sea area during the last 15,000 years. The Holocene 15, 576-584.

Bahr, A., Lamy, F., Arz, H.W., Kuhlmann, H., Wefer, G., 2005. Late glacial to Holocene climate and sedimentation history in the NW Black Sea. Marine Geology 214, 309-322.

Bahr, A., Arz, H.W., Lamy, F., Wefer, G., 2006. Late glacial to Holocene paleoenvironmental evolution of the Black Sea, reconstructed with stable oxygen isotope records obtained on ostracod shells. Earth and Planetary Science Letters 241, 863-875.

Beug, H.-J., 2004. Leitfaden der Pollenbestimmung für Mitteleuropa und angrenzende Gebiete. Pfeil, München (in German).

Bond, G., Lotti, R., 1995. Iceberg Discharges into the North Atlantic on Millenial Time Scales During the Last Glaciation. Science 267, 1005-1010.

Bond, G., Broecker, W., Johnsen, S., McManus, J., Labeyrie, L., Jouzel, J., Bonani, G., 1993. Correlations between climate records from North Atlantic sediments and Greenland ice. Nature 365, 143-147. 
Buynevich, I.V., Yanko-Hombach, V., Gilbert, A.S., Martin, R.E. (Eds.), 2011. Geology and Geoarchaeology of the Black Sea Region: beyond the flood hypothesis. The Geological Society of America, Boulder, USA.

Chester, P.I., Raine, J.I., 2001. Pollen and spore keys for Quaternary deposits in the northern Pindos Mountains, Greece. Grana 40, 299-387.

Dansgaard, W., Johnsen, S., Clausen, H.B., Dahl-Jensen, D., Gundestrup, N.S., Hammer, C.U., Hyidberg, C.S., Steffensen, J., Sveinbjörnsdottir, A.E., Jouzel, J., Bond, G., 1993. Evidence for general instability of past climate from a 250-kyr ice-core record. Nature $364,218-220$.

Erdtman, G., 1960. The acetolysis method. Svensk Botanisk Tidskrift 54, 561-564.

Filipova-Marinova, M., Pavlov, D., Coolen, M., Giosan, L., 2012. First high-resolution marinopalynological stratigraphy of the Late Quaternary sediments from the central part of the Bulgarian Black Sea area. Quaternary International, doi:10.1016/j.quaint.2012.05.002.

Fleitmann, D., Cheng, H., Badertscher, S., Edwards, R.L., Mudelsee, M., Göktürk, O.M., Fankhauser, A., Pickering, R., Raible, C.C., Matter, A., Kramers, J., Tüysüz, O., 2009. Timing and climatic impact of Greenland interstadials recorded in stalagmites from northern Turkey. Geophysical Research Letters 36, doi:10.1029/2009GL040050.

Fletcher, W.J., Sánchez-Goñi, M.F., Allen, J.R.M., Cheddadi, R., Combourieu-Nebout, N., Huntley, B., Lawson, I., Londeix, L., Magri, D., Margari, V., Müller, U., Naughton, F., Novenko, E., Roucoux, K., Tzedakis, P., 2010. Millennial-scale variability during the last glacial in vegetation records from Europe. Quaternary Science Reviews 29, 28392864.

Grootes, P.M., Stuiver, M., White, J.W.C., Johnsen, S., Jouzel, J., 1993. Comparison of oxygen isotope records from the GISP2 and GRIP Greenland ice cores. Nature 366, $552-554$.

Heinrich, H., 1988. Origin and Consequences of Cyclic Ice Rafting in the Northeast Atlantic Ocean during the Past 130,000 Years. Quaternary Research 29, 142-152.

Hemming, S.R., 2004. Heinrich events: Massive late Pleistocene detritus layers of the North Atlantic and their global climate imprint. Review of Geophysics 42, RG1005, doi:10.1029/2003RG000128.

Juggins, S., 2003. C2 User Guide. Software for Ecological and Palaeoecological Data Analysis and Visualisation. University of Newcastle, Newcastle upon Tyne. 
Kosarev, A.N., Kostianoy, A.G., 2008. Introduction. In: Kostianoy, G., Kosarev, A.N. (Ed.), The Handbook of Environmental Chemistry: Vol.5, Part Q: The Black Sea Environment. Springer Verlag, Berlin - Heidelberg, pp. 1-10.

Kouli, K., Brinkhuis, H., Dale, B., 2001. Spiniferites cruciformis: a fresh water dinoflagellate cyst? Review of Palaeobotany and Palynology 113, 273-286.

Kudrass, H.R., Hofmann, A., Doose, H., Emeis, K., Erlenkeuser, H., 2001. Modulation and amplification of climatic changes in the Northern Hemisphere by the Indian summer monsoon during the past 80 k.y. Geology 29, 63-66.

Leroy, S.A.G., Albay, M., 2010. Palynomorphs of brackish and marine species in cores from the freshwater Lake Sapanca, NW Turkey. Review of Palaeobotany and Palynology 160, 181-188.

Margari, V., Gibbard, P.L., Bryant, C.L., Tzedakis, P.C., 2009. Character of vegetational and environmental changes in southern Europe during the last glacial period; evidence from Lesvos Island, Greece. Quaternary Science Reviews 28, 1317-1339.

Marret, F., Zonneveld, K.A.F., 2003. Atlas of modern organic-walled dinoflagellate cyst distribution. Review of Palaeobotany and palynology 125, 1-200.

Marret, F., Leroy, S., Chalié, F., Gasse, F., 2004. New organic-walled dinoflagellate cysts from recent sediments of Central Asian seas. Review of Palaeobotany and Palynology $129,1-20$.

Mayer, H., Aksoy, H., 1986. Wälder der Türkei. Gustav Fischer Verlag, Stuttgart-New York (in German).

Moore, P.D., Webb, J.A., Collinson, M.E., 1999. Pollen analysis. Blackwell, Oxford.

Moreno, A., Cacho, I., Canals, M., Grimalt, J.O., Sanchez-Vidal, A., 2004. Millennial-scale variability in the productivity signal from the Alboran Sea record, Western Mediterranean Sea. Palaeogeography, Palaeoclimatology, Palaeoecology 211, 205 219.

Mudie, P.J., Rochon, A., Aksu, A.E., Gillespie, H., 2004. Late glacial, Holocene and modern dinoflagellate cyst assemblages in the Aegean - Marmara - Black Sea corridor: statistical analysis and re-interpretation of the early Holocene Noah's Flood hypothesis. Review of Palaeobotany and Palynlogy 128, 143-167.

Müller, U.C., Pross, J., Tzedakis, P.C., Gamble, C., Kotthoff, U., Schmiedl, G., Wulf, S., Christianis, K., 2011. The role of climate in the spread of modern humans into Europe. Quaternary Science Reviews 30, 273-279. 
Neprochnov, Yu.P. (Ed.), 1980. Geologicheskaya istoriya Chernogo moria po resul'tatam glubokovodnogo bureniya. Nauka, Moscow (in Russian).

Nowaczyk, N.R., Arz, H.W., Frank, U., Kind, J., Plessen, B., 2012. Dynamics of the Laschamp geomagnetic excursion from the Black Sea sediments. Earth and Planetary Science Letters 351-352, 54-69.

Özsoy, E., Ünlüata, Ü., 1997. Oceanography of the Black Sea: a review of some recent results. Earth-Science Reviews 42, 231-272.

Pospelova, V., Pedersen, T.F., de Vernal, A., 2006. Dinoflagellate cysts as indicators of climatic and oceanographic changes during the past $40 \mathrm{kyr}$ in the Santa Barbara Basin, southern California. Paleoceanography, 21, PA2010, doi:10.1029/2005PA001251.

Rahmstorf, S., 2002. Ocean circulation and climate during the past 120,000 years. Nature 419, 207-214.

Ross, D.A., Neprochnov, Y.P. et al. (Eds.), 1978. Initial Reports of the Deep Sea Drilling Project. Volume 42, part 2, U.S. Government Printing Office, Washington.

Roucoux, K.H., de Abreu, L., Shackleton, N.J., Tzedakis, P.C., 2005. The response of NW Iberian vegetation to North Atlantic climate oscillations during the last $65 \mathrm{kyr}$. Quaternary Science Reviews 24, 1637-1653.

Sánchez-Goñi, M.F., Turon, J.-L., Eynaud, F., Gendreau, S., 2000. European Climatic Response to Millennial-Scale Changes in the Atmosphere-Ocean System during the Last Glacial. Quaternary Research 54, 394-403.

Sánchez-Goñi, M.F., Cacho, I., Turon, J.-L., Guiot, J., Sierro, F.J., Peypouquet, J.-P., Grimalt, J.O., Shackleton, N.J., 2002. Synchroneity between marine and terrestrial responses to millennial scale climatic variability during the last glacial period in the Mediterranean region. Climate Dynamics 19, 95-105.

Shumilovskikh, L.S., Tarasov, P., Arz, H., Fleitmann, D., Marret, F., Nowaczyk, N., Plessen, B., Schlütz, F., Behling, H., 2012. Vegetation and environmental dynamics in the southern Black Sea region since $18 \mathrm{kyr}$ BP derived from the marine core 22-GC3. Palaeogeography, Palaeoclimatology, Palaeoecology, 337-338, 177-193.

Shumilovskikh, L.S., Marret, F., Fleitmann, D., Arz, H., Nowaczyk, N., Behling, H., in review. Eemian and Holocene sea-surface conditions in the southern Black Sea: organic-walled dinoflagellate cyst record from core 22-GC3. Marine Micropaleontology.

Stockmarr, J., 1971. Tablets with Spores used in Absolute Pollen Analysis. Pollen et Spores $13,615-621$. 
Svitoch, A.A., 2008. Quaternary Paleogeography of the Azov-Black Sea Basin. In: Kostianoy, G., Kosarev, A.N. (Eds.), The Handbook of Environmental Chemistry: Vol.5, Part Q: The Black Sea Environment. Springer Verlag, Berlin - Heidelberg, pp. 31-46.

Wall, D., Dale, B., Harada, K., 1973. Descriptions of new fossil dinoflagellates from the Late Quaternary of the Black Sea. Micropaleontology 19, 18-31.

Yu, S.-Y., Berglund, B.E., 2007. A dinoflagellate cyst record of Holocene climate and hydrological changes along the southeastern Swedish Baltic coast. Quaternary Research 67, 215-224.

Zohary, M., 1973. Geobotanical foundations of the Middle East. Fischer, Stuttgart, Amsterdam. 


\section{MANUSCRIPT 5}

\section{Recent pollen distribution in Northern Anatolia and the SE Black Sea: preliminary results}

Lyudmila Shumilovskikh ${ }^{\mathrm{a}}$, Frank Schlütz ${ }^{\mathrm{b}}$, Hermann Behling ${ }^{\mathrm{a}}$

a Department of Palynology and Climate Dynamics, University of Göttingen, Untere Karspüle 2, 37073 Göttingen, Germany

b Lower Saxony Institute for Historical Coastal Research, Viktoriastrasse 26/28, 26382

Wilhelmshaven, Germany

Ongoing study 


\begin{abstract}
The present study presents the preliminary results of the ongoing palynological study on surface samples from Northern Anatolia and the Black Sea. It shows that pollen distribution in three transects across the Pontic Mountains reflects vegetation patterns of the area, which are controlled by climate and topography. The comparison of the top sample from the Black Sea with surface samples on land suggest the nearest coastal areas and northern slopes of the Pontic Mountains as the main pollen source area for the marine core 22-GC3.
\end{abstract}

Key words: modern surface samples, pollen source area, Turkey 


\section{Introduction}

The offshore core 22-GC3 from Southern Black Sea was used for the reconstruction of vegetation and climate changes in Northern Anatolia (Turkey) during the Eemian, last glacial and the Holocene period (Shumilovskikh et al., 2012; Shumilovskikh et al., submitted). Based on an analysis of the literature (Stanley, 1965; Cross et al., 1966; Groot, 1966; Groot and Groot, 1966; Koreneva, 1966; Traverse and Ginsburg, 1966; Zagwijn and Veenstra, 1966; Shatilova, 1974; Hooghiemstra et al., 2006), the authors assumed the adjacent region, namely Northern Anatolia, as the main pollen source area. As the core 22-GC3 is located $70-80 \mathrm{~km}$ from the coast, it remained unclear which part of Northern Anatolia contributed the most pollen to the core site. In order to define the pollen source area for the core 22-GC3 more exactly, we study surface samples from Northern Anatolia (Fig. 1) and compare them with the top sample of the core 22-GC3. Here we present preliminary results of the study.

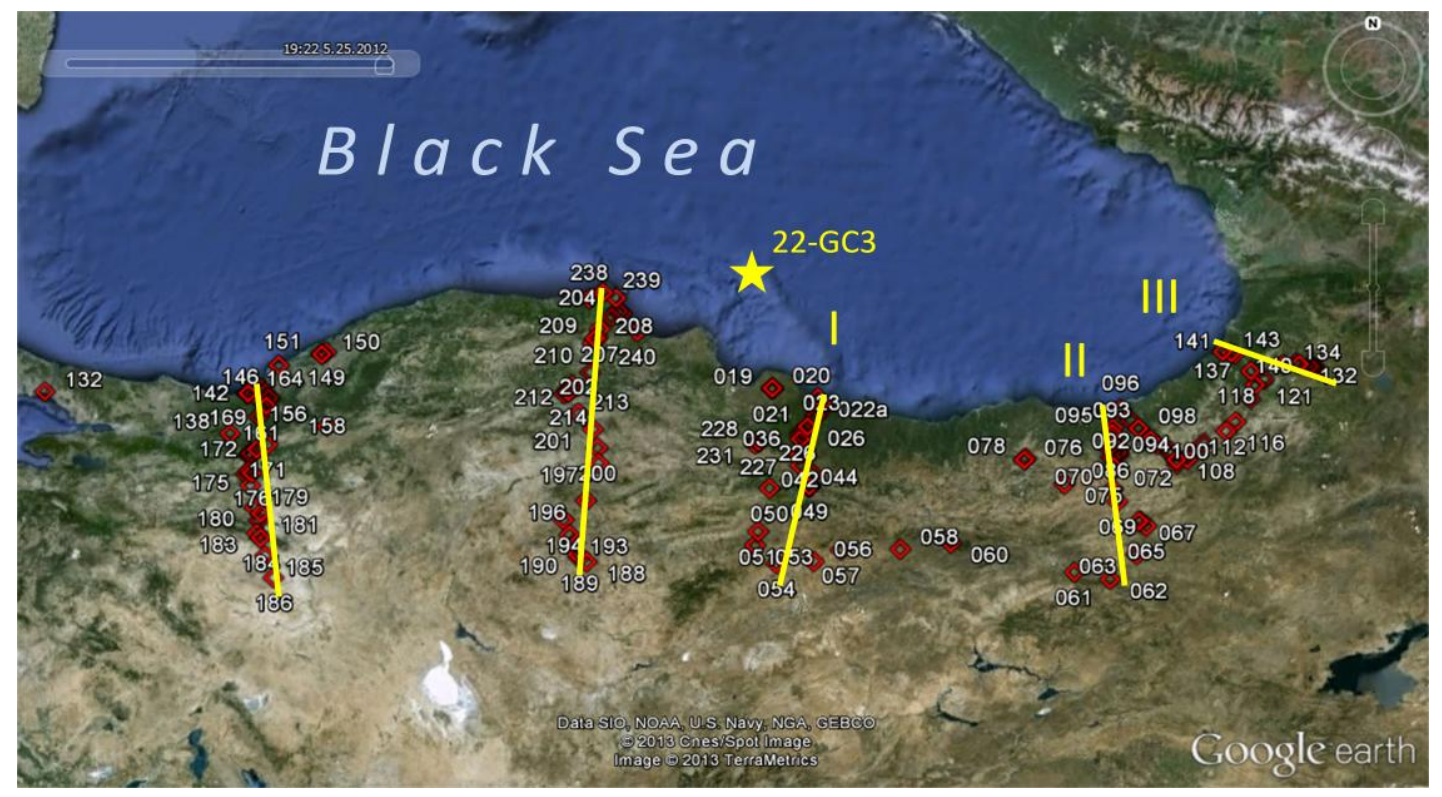

Fig. 1. Map of Northern Anatolia displaying the locations of core 22-GC3, as well as five transects where surface samples were taken in 2011 and 2012, including transects I, II and III for which preliminary results are presented here.

\section{Geographical setting}

The moist northern and western slopes of the Pontic mountains up to $\sim 800 \mathrm{~m}$ above sea level (asl) are covered by euxinian mixed forests with cool (Carpinus betulus, Fagus orientalis, deciduous Quercus, Corylus, Tilia) and warm (Castanea sativa, Carpinus orientalis, Ostrya carpinifolia) temperate deciduous trees, evergreen shrubs (Rhododendron ponticum, Prunus laurocerasus, Buxus sempervierens, Ilex colchica) and lianas (Hedera, Smilax, Tamus, Vitis, Periploca). Characteristic species of the Mediterranean macchia, such 166 
as Laurus nobilis, Arbutus andrachne, Erica arborea, Phillyrea latifolia, Quercus coccifera, grow in dry habitats along the Black Sea coast (Zohary, 1973; Mayer and Aksoy, 1986). At elevations of $\sim 800-1500 \mathrm{~m}$ asl, beech (Fagus orientalis) and hornbeam-beech (Carpinus betulus-Fagus orientalis) forests predominate, whereas areas at altitudes above $\sim 1500 \mathrm{~m}$ are occupied by firs (Abies nordmanniana) in western and spruce (Picea orientalis) in the eastern Pontic Mountains. The subalpine and alpine belt above $2000 \mathrm{~m}$ asl is dominated by grasslands with Juniperus communis. The south-east mountain slopes facing the Anatolian Plateau are covered by drier vegetation types, including open woodlands dominated by junipers (Juniperus excelsa, J. oxycedrus) and deciduous oaks (Quercus pubescens, Q. trojana), growing at the border between forest and steppe. In contrast, pines (Pinus nigra, P. sylvestris) together with Betula and Populus form the high-altitude forest line at $\sim 2000 \mathrm{~m}$. Above this elevation and in the dry central regions of Anatolia, thorny shrubs such as Astracanthus, Acantholimon, Sarcopoterium are characteristic.

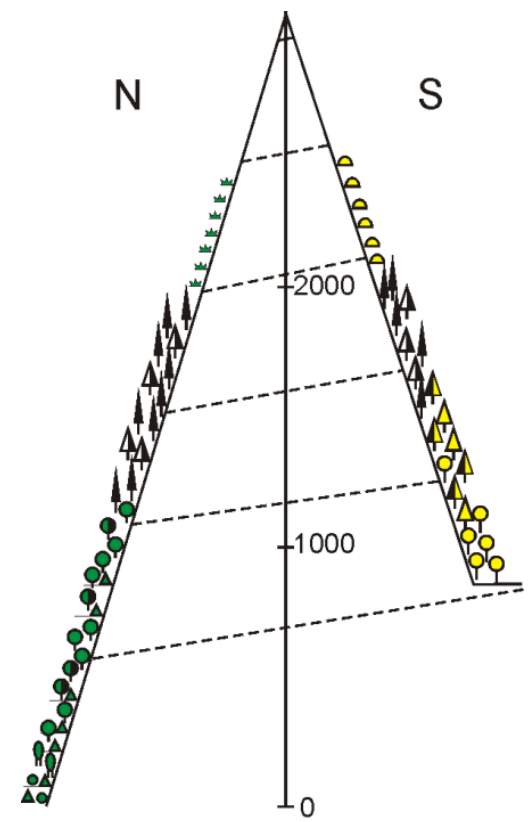

“ alpine meadows

- Fagus orientalis

- deciduous trees

- Corylus avellana

- Rhododendron ponticum

- evergreen shrubs

- Abies nordmanniana, A. bornmüllereriana

4 Picea orientalis, Pinus sylvestris

- thorny shrubland

4 Pinus nigra

$\triangle$ Juniperus excelsa

Q Quercus pubescens, Q. spec.

Fig. 2. Vegetation distribution of the Pontic Mountains.

\section{Material and methods}

Collection of surface samples was organized in five main transects from the Black Sea coast across the Pontic Mountains towards the inner part of Anatolia (Fig. 1). A total of about 165 surface samples were collected during two field trips in Northern Anatolia in 2011(90 samples) and 2012 (75 samples) (Table 1). Every surface sample (mosses, litter, soil) consists of several sub-samples collected in sampling areas of a few to a hundred square meters (Herzschuh et al., 2005; Hicks, 2007). In order to homogenize the material, each sample was 
oven-dried at $40^{\circ} \mathrm{C}$ for one night, crushed and mixed. Laboratory treatment included $\mathrm{HCl}$ (10\%), sieving through a metallic sieve with a mesh size of $150 \mu \mathrm{m}$, HF (70\% during two nights), acetolysis ( 3 minutes), and sieving through a nylon sieve (1-2 $\mu \mathrm{m}) .31$ samples from 2011 (Table 1) covering three transects (Fig. 1) were selected for the preliminary study. Palynological analyses were carried out under 400x magnification. A minimum of 300-350 identified pollen grains were counted in each sample and used for the calculation of percentages. The diagram (Figs. 3) was constructed using the software C2 (version 1.6.6) (Juggins, 2003).

Table 1. Description of surface samples, collected in Northern Anatolia in 2011 and 2012. Highlighted samples indicate those discussed in this study.

\begin{tabular}{|c|c|c|c|c|}
\hline Sample & Latitude & Longitude & Altitude, $\mathbf{m}$ & Vegetation \\
\hline 2011_19 & 41.22 & 36.73 & -4 & Populus-Rubus floodplain \\
\hline 2011_20 & 41.23 & 36.72 & 6 & Corylus plantation \\
\hline 2011_21 & 41.22 & 36.72 & 6 & Zea mays plantation \\
\hline 2011_22a & 41.14 & 37.19 & 12 & Alnus-Fraxinus floodplain forest \\
\hline 2011_23 & 41.10 & 37.23 & 102 & Carpinus-Fagus-Castanea forest \\
\hline 2011_24 & 41.04 & 37.22 & 376 & Castanea-Fagus forest \\
\hline 2011_25 & 41.00 & 37.17 & 491 & Fagus-Castanea forest \\
\hline 2011_26 & 40.91 & 37.08 & 1076 & Fagus-Carpinus forest \\
\hline 2011_33 & 40.88 & 37.05 & 1094 & Rhododendron luteum pasture \\
\hline 2011_34 & 40.85 & 37.01 & 1310 & Fagus forest \\
\hline 2011_36 & 40.81 & 37.01 & 1278 & Fagus forest \\
\hline 2011_37 & 40.78 & 37.04 & 1408 & Fagus forest \\
\hline 2011_39 & 40.72 & 37.04 & 1082 & Quercus-Pinus sylvestris forest \\
\hline 2011_40 & 40.71 & 37.01 & 989 & Pinus sylvestris forest \\
\hline 2011_42 & 40.68 & 37.00 & 1153 & Pinus sylvestris forest with Fagus scrub \\
\hline 2011_43 & 40.71 & 37.02 & 954 & Quercus-Carpinus orientalis forest \\
\hline 2011_44 & 40.59 & 37.00 & 713 & $\begin{array}{l}\text { Quercus dec.-Quercus coccifera-Juniperus } \\
\text { oxycedrus forest }\end{array}$ \\
\hline 2011_48 & 40.52 & 37.12 & 1403 & Fagus orientalis-Taxus baccata forest \\
\hline 2011_49.1 & 40.42 & 37.09 & 729 & Ceder libani forest (under trees) \\
\hline $2011 \_49.2$ & 40.42 & 37.09 & 729 & Ceder libani forest (between trees) \\
\hline 2011_50 & 40.41 & 36.68 & 719 & Quercus dec.-Carpinus orientalis forest \\
\hline 2011_51 & 40.05 & 36.56 & 1239 & Quercus pubescens-Juniperus oxycedrus/excelsa \\
\hline 2011_53.1 & 39.94 & 36.53 & 1586 & Poaceae-thorn shrubs (on slope) \\
\hline 2011_53.2 & 39.94 & 36.53 & 1586 & Poaceae-thorn shrubs (on stone) \\
\hline 2011_54 & 39.79 & 36.74 & 1392 & Thorn shrub/ pasture \\
\hline 2011_56 & 39.80 & 37.13 & 1427 & Steppe on gypsum \\
\hline 2011_57 & 39.89 & 37.40 & 1432 & Steppe on gypsum \\
\hline 2011_58.1 & 39.89 & 38.01 & 1642 & Juniperus excelsa forest (on stone) \\
\hline 2011_58.2 & 39.89 & 38.01 & 1642 & Juniperus excelsa forest (on slope between junipers) \\
\hline 2011_58.3 & 39.89 & 38.01 & 1642 & Juniperus excelsa forest (on slope under junipers) \\
\hline
\end{tabular}




\begin{tabular}{|c|c|c|c|c|}
\hline $2011 \_60$ & 39.93 & 38.53 & 1636 & $\begin{array}{l}\text { Quercus-Pinus sylvestris-Juniperus } \\
\text { oxycedrus/communis forest }\end{array}$ \\
\hline 2011_61 & 39.65 & 39.79 & 1302 & Astracanthus-steppe \\
\hline 2011_62 & 39.57 & 40.16 & 1416 & Astracanthus-Prunus forest steppe \\
\hline 2011_63 & 39.76 & 40.45 & 1568 & Artemisia-Astracanthus steppe \\
\hline 2011_65 & 39.99 & 40.56 & 1822 & Poaceae-Acantholimon steppe \\
\hline 2011_66 & 40.04 & 40.51 & 2416 & alpine meadow \\
\hline 2011_67 & 40.04 & 40.49 & 2276 & alpine meadow \\
\hline 2011_69 & 40.21 & 40.27 & 1664 & Artemisia-Poaceae-thorn shrub-steppe \\
\hline 2011_70 & 40.32 & 40.23 & 1579 & Poaceae steppe \\
\hline 2011_71.1 & 40.48 & 40.26 & 1807 & Thorn shrub-steppe (on stone) \\
\hline 2011_71.2 & 40.48 & 40.26 & 1807 & Thorn shrub-steppe (on stone) \\
\hline 2011_71.3 & 40.48 & 40.26 & 1807 & Thorn shrub-steppe (on slope) \\
\hline 2011_72 & 40.50 & 40.25 & 2054 & Alpine meadow \\
\hline 2011_75 & 40.38 & 39.73 & 1621 & Quercus-Juniperus-Pinus-Corylus forest \\
\hline 2011_76 & 40.59 & 39.32 & 1261 & Pinus sylvestris-Quercus forest \\
\hline 2011_78 & 40.60 & 39.34 & 1340 & Picea forest \\
\hline 2011_84 & 40.58 & 40.23 & 1279 & Picea orientalis-Corylus forest \\
\hline 2011_85 & 40.65 & 40.21 & 807 & Picea mixed forest \\
\hline 2011_86 & 40.68 & 40.23 & 617 & Fagus-Castanea-Picea-Carpinus betulus forest \\
\hline 2011_87 & 40.59 & 40.31 & 1797 & Picea-Fagus-Rhododendron luteum forest \\
\hline 2011_88 & 40.61 & 40.30 & 1619 & $\begin{array}{l}\text { Picea-Fagus orientalis-Rhododendron ponticum } \\
\text { forest }\end{array}$ \\
\hline 2011_90 & 40.62 & 40.30 & 1237 & Picea-Fagus orientalis forest \\
\hline 2011_91 & 40.68 & 40.25 & 592 & mixed forest \\
\hline 2011_92 & 40.71 & 40.23 & 373 & mixed forest \\
\hline 2011_93 & 40.75 & 40.25 & 273 & mixed forest \\
\hline 2011_94 & 40.78 & 40.25 & 230 & mixed forest \\
\hline 2011_95 & 40.82 & 40.27 & 142 & mixed forest \\
\hline 2011_96 & 40.97 & 40.37 & 24 & Camellia sinensis plantation \\
\hline 2011_97.1 & 40.87 & 40.46 & 155 & $\begin{array}{l}\text { Fagus-Castanea forest between Camellia sinensis } \\
\text { plantations }\end{array}$ \\
\hline 2011_97.2 & 40.87 & 40.46 & 155 & under Camellia sinensis shrubs \\
\hline 2011_98 & 40.80 & 40.54 & 407 & mixed forest \\
\hline 2011_99 & 40.73 & 40.60 & 933 & mixed forest under Camellia sinensis shrubs \\
\hline 2011_100 & 40.71 & 40.65 & 1433 & Picea forest \\
\hline 2011_101 & 40.66 & 40.72 & 2066 & alpine meadow \\
\hline 2011_104.1 & 40.61 & 40.85 & 2351 & alpine meadow \\
\hline 2011_104.2 & 40.61 & 40.85 & 2351 & alpine meadow \\
\hline 2011_105.1 & 40.58 & 40.85 & 2212 & Astracanthus meadow (on stone) \\
\hline 2011_105.2 & 40.58 & 40.85 & 2212 & Astracanthus meadow (on slope) \\
\hline 2011_108 & 40.53 & 40.92 & 1811 & Quercus forest-steppe \\
\hline 2011_109 & 40.49 & 40.92 & 1493 & Quercus-Amygdalis forest-steppe \\
\hline 2011_112 & 40.53 & 41.04 & 1223 & floodplain (on rock) \\
\hline 2011_113 & 40.56 & 41.08 & 1016 & Artemisia-Juniperus forest steppe \\
\hline 2011_115 & 40.65 & 41.22 & 861 & Paliurius-Juniperus oxycedrus forest-steppe \\
\hline 2011_116 & 40.74 & 41.47 & 729 & Paliurius-Juniperus oxycedrus forest-steppe \\
\hline 2011_118 & 40.81 & 41.58 & 537 & Ephedra-Paliurius \\
\hline
\end{tabular}




\begin{tabular}{|c|c|c|c|c|}
\hline 2011_119 & 40.99 & 41.77 & 340 & Juniperus \\
\hline 2011_121 & 41.10 & 41.83 & 239 & Olea plantation \\
\hline 2011_122 & 41.15 & 41.93 & 260 & Quercus-Juniperus forest-steppe \\
\hline 2011_124 & 41.20 & 42.52 & 2429 & alpine meadow \\
\hline 2011_125 & 41.22 & 42.47 & 2281 & alpine meadow \\
\hline 2011_126 & 41.23 & 42.47 & 2195 & Pinus forest \\
\hline 2011_127 & 41.22 & 42.46 & 2007 & Abies forest \\
\hline 2011_128 & 41.23 & 42.44 & 1688 & Picea-Abies-Pinus forest \\
\hline 2011_132 & 41.25 & 42.33 & 1033 & Picea forest \\
\hline 2011_133 & 41.26 & 42.29 & 805 & Carpinus-Quercus forest \\
\hline 2011_134 & 41.26 & 42.15 & 603 & Quercus forest-steppe \\
\hline 2011_137 & 41.22 & 41.79 & 257 & Arbutus andrachne-Quercus-Cistus \\
\hline 2011_140 & 41.37 & 41.64 & 217 & Carpinus-Alnus-Corylus forest \\
\hline 2011_141 & 41.38 & 41.60 & 250 & Castanea-Corylus-Alnus forest \\
\hline 2011_143 & 41.39 & 41.50 & 368 & mixed forest \\
\hline 2012_135.1 & 40.59 & 31.28 & 1441 & Juniperus-Poaceae pasture \\
\hline 2012_136 & 40.60 & 31.27 & 1426 & Fagus forest \\
\hline 2012_137 & 40.60 & 31.29 & 1379 & Abies forest \\
\hline 2012_138 & 40.76 & 31.04 & 123 & floodplain \\
\hline 2012_140 & 41.10 & 31.21 & 16 & Submediterranean open forest \\
\hline 2012_141 & 41.10 & 31.21 & 24 & Corylus plantation \\
\hline 2012_142 & 41.10 & 31.22 & 2 & Black Sea coast \\
\hline 2012_144 & 41.09 & 31.27 & 24 & Pterocarya-Alnus floodplain forest \\
\hline 2012_145 & 41.15 & 31.35 & 48 & Laurus-Quercus forest \\
\hline 2012_146 & 41.34 & 31.53 & 342 & Pinus pinaster forest \\
\hline 2012_149.1 & 41.47 & 32.03 & 77 & Pistacia pasture \\
\hline 2012_150 & 41.45 & 31.99 & 254 & Carpinus betulus mixed forest \\
\hline 2012_151.1 & 41.45 & 31.99 & 152 & floodplain forest \\
\hline 2012_151.2 & 41.45 & 31.99 & 152 & floodplain forest \\
\hline 2012_156 & 40.86 & 32.08 & 860 & Pinus nigra forest \\
\hline 2012_163 & 41.11 & 31.40 & 136 & Mischwald between Corylus plantations \\
\hline 2012_165 & 41.07 & 31.44 & 200 & Fagus mixed forest \\
\hline 2012_166 & 41.06 & 31.45 & 170 & Phillyrea latifolia open forest \\
\hline 2012_167 & 41.01 & 31.40 & 395 & Fagus forest \\
\hline 2012_169 & 41.00 & 31.42 & 533 & Pinus sylvestris-Fagus forest \\
\hline 2012_170 & 40.91 & 31.35 & 615 & Fagus-Rhododendron ponticum forest \\
\hline 2012_171 & 40.68 & 31.46 & 904 & Fagus-Abies forest \\
\hline 2012_172 & 40.64 & 31.34 & 1064 & Abies-Fagus forest \\
\hline 2012_173 & 40.58 & 31.27 & 1233 & Quercus-Pinus-Juniperus forest \\
\hline 2012_175 & 40.46 & 31.28 & 1186 & Quercus dec.-Pinus nigra forest \\
\hline 2012_176 & 40.44 & 31.30 & 1234 & Pinus nigra-Astragalus forest \\
\hline 2012_177 & 40.43 & 31.24 & 1396 & Pinus-Corylus forest \\
\hline 2012_179 & 40.34 & 31.29 & 876 & Quercus open forest \\
\hline 2012_180.1 & 40.16 & 31.35 & 612 & Juniperus excelsa-Genista shrubland \\
\hline 2012_181 & 40.11 & 31.42 & 496 & Artemisia-Genista steppe \\
\hline 2012_182 & 40.05 & 31.40 & 568 & Juniperus excelsa-Paliurius forest \\
\hline 2012_183 & 39.95 & 31.39 & 1287 & Juniperus-Quercus-Pinus forest \\
\hline
\end{tabular}




\begin{tabular}{|c|c|c|c|c|}
\hline 2012_184 & 39.91 & 31.43 & 1585 & Pinus nigra forest \\
\hline 2012_185 & 39.76 & 31.48 & 800 & Poaceae steppe \\
\hline 2012_186.1 & 39.58 & 31.58 & 1161 & Astragalus-Juniperus oxycedrus shrubland \\
\hline 2012_188 & 39.80 & 34.81 & 1543 & Pinus nigra forest \\
\hline 2012_189 & 39.84 & 34.73 & 1232 & Astragalus-Poaceae steppe \\
\hline 2012_190.1 & 39.87 & 34.72 & 1254 & Quercus-Astracanthus open forest \\
\hline 2012_191 & 39.96 & 34.69 & 1251 & Quercus-Poaceae open forest \\
\hline 2012_193 & 40.02 & 34.63 & 1191 & Quercus forest \\
\hline 2012_194 & 40.14 & 34.57 & 970 & Poaceae-Artemisia steppe \\
\hline 2012_196 & 40.31 & 34.80 & 1122 & Quercus dec. forest \\
\hline 2012_197 & 40.61 & 34.93 & 925 & Poaceae-Artemisia-Astracanthus shrubland \\
\hline 2012_200 & 40.74 & 34.91 & 786 & Quercus dec.-Carpinus orientalis forest \\
\hline 2012_201 & 40.89 & 34.86 & 453 & Paliurius pasture \\
\hline 2012_202 & 41.02 & 34.71 & 716 & Pinus brutia forest \\
\hline 2012_204 & 41.97 & 35.09 & 30 & mixed forest between crop fields \\
\hline 2012_205 & 41.81 & 35.04 & 273 & Submediterranean open forest \\
\hline 2012_207 & 41.71 & 34.92 & 771 & Quercus dec. mixed forest \\
\hline 2012_208 & 41.63 & 34.87 & 1363 & Poaceae meadow \\
\hline 2012_209 & 41.64 & 34.90 & 1237 & Fagus forest \\
\hline 2012_210 & 41.59 & 34.85 & 796 & Quercus-Juniperus open forest \\
\hline 2012_211 & 41.36 & 34.83 & 457 & Quercus-Juniperus open forest \\
\hline 2012_212 & 41.25 & 34.64 & 1179 & Fagus forest \\
\hline 2012_213 & 41.21 & 34.63 & 1414 & Abies-Pinus-Fagus forest \\
\hline 2012_214 & 41.19 & 34.60 & 1492 & Pinus-Juniperus communis pasture \\
\hline 2012_215 & 41.18 & 34.56 & 1000 & Quercus-Juniperus open forest \\
\hline 2012_218 & 40.42 & 37.09 & 711 & near Ceder libani forest (on stone) \\
\hline 2012_219 & 40.42 & 37.09 & 701 & near Ceder libani forest (on slope) \\
\hline 2012_220 & 40.42 & 37.09 & 725 & Ceder libani forest \\
\hline 2012_221 & 40.42 & 37.09 & 734 & Quercus forest near Ceder libani forest \\
\hline 2012_222 & 40.42 & 37.09 & 717 & open Ceder libani forest \\
\hline 2012_223 & 40.42 & 37.09 & 699 & near Ceder libani forest \\
\hline 2012_224 & 40.43 & 37.09 & 576 & $500 \mathrm{~m}$ from Ceder libani forest \\
\hline 2012_226 & 40.79 & 36.57 & 1235 & Ceder-Quercus forest \\
\hline 2012_227 & 40.79 & 36.57 & 1237 & $50 \mathrm{~m}$ from Ceder libani forest \\
\hline 2012_228 & 40.79 & 36.57 & 1237 & Fagus forest \\
\hline 2012_231 & 40.77 & 36.54 & 759 & Pinus brutia-Arbutus andrachne open forest \\
\hline 2012_236 & 41.84 & 35.15 & 8 & Submediterranean vegetation on Black Sea coast \\
\hline 2012_237 & 41.86 & 35.11 & 136 & Laurus-Quercus-Carpinus orientalis forest \\
\hline 2012_238 & 41.96 & 34.81 & 8 & Pinus-Myrtus communis forest \\
\hline 2012_239 & 42.01 & 34.95 & 81 & Fagus-Quercus-Carpinus betulus forest pasture \\
\hline 2012_240 & 41.69 & 35.31 & 317 & Pinus nigra-Cotinus coggygria forest \\
\hline 2012_241 & 41.63 & 36.11 & -1 & Coast and dune vegetation \\
\hline 2012_246 & 41.67 & 36.03 & 3 & Salt marsh \\
\hline
\end{tabular}




\section{Description of the results}

The pollen diagram of the surface samples from Northern Anatolia (Fig. 3) is organized by three studied transects I-III (Fig. 1). The samples within each transect are ordered by the distance from the Black Sea with the upper sample the closest to the sea.

The pollen spectra of transect I are dominated by Pinus diploxylon-type. The closest samples to the sea, 24, 25 and 36, collected at 350-1300 m above sea-level (asl) show 76-93\% arboreal pollen (AP) with Fagus, Corylus, Carpinus betulus, Alnus, Ulmus/Zelkova, Castanea, Tilia. Non-arboreal pollen (NAP) consists mainly of Xanthum spinosum-type and Chenopodiaceae. The pollen spectra of the next four samples further inland (43, 49.1, 50, and 51) from altitudes 700-1000 m are dominated by Pinus diploxylon-type, Quercus robur-type and Ostrya-type. The two samples 53.2 and 57 (1400-1600 m asl) next to the steppe are characterized by high NAP values (28-53\%), dominated by Artemisia and Poaceae.

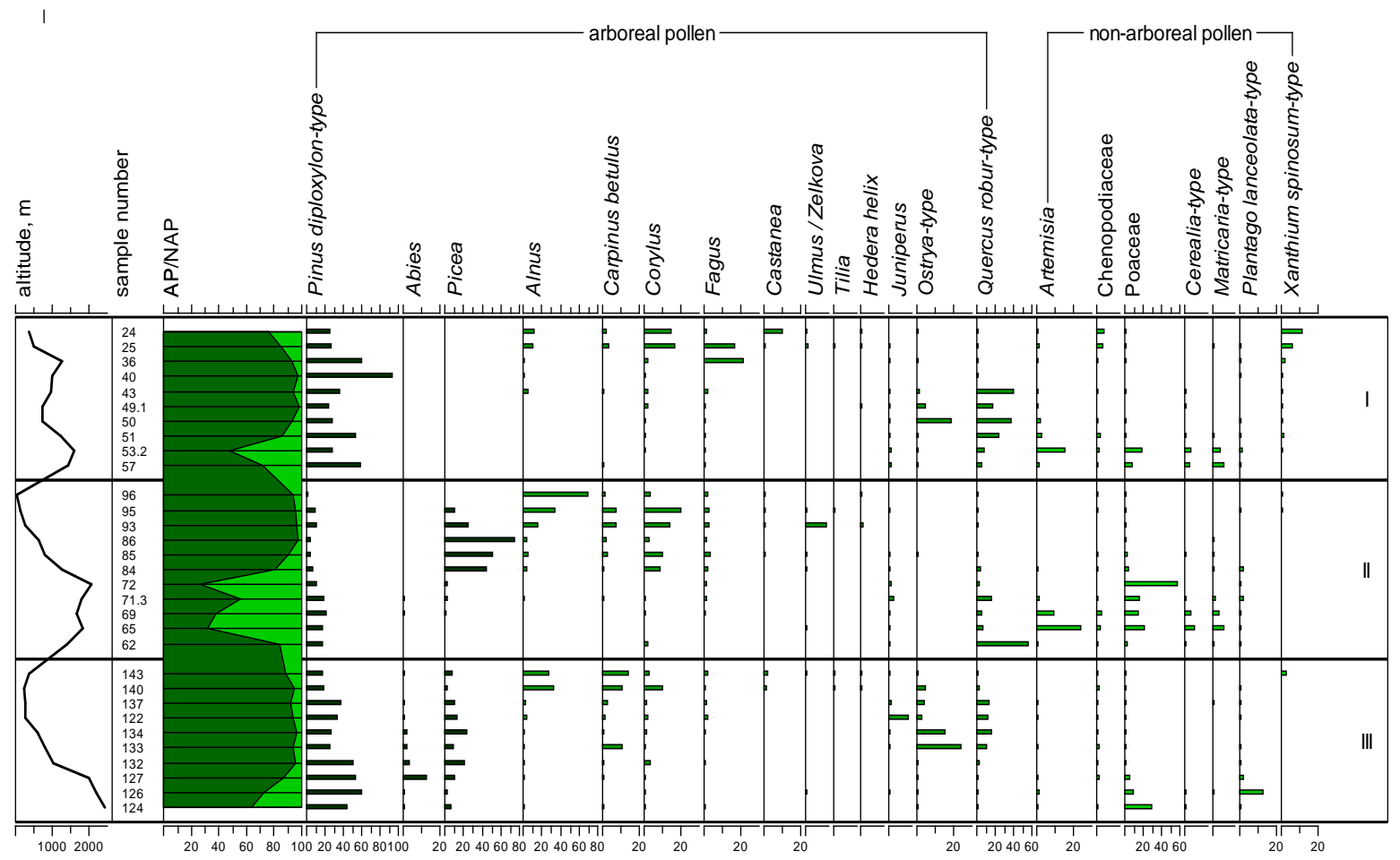

Fig. 3. Pollen spectra of surface samples with the main pollen taxa from transects I, II and III (Fig. 1) in Northern Anatolia, discussed in the text.

The three samples closest to Black Sea (96, 95, and 93) from transect II (24 to $617 \mathrm{~m}$ asl), are dominated by Alnus, Corylus, Ulmus/Zelkova, Carpinus betulus and Picea. NAP is presented by Xanthum spinosum-type and Chenopodiaceae as well. Samples 86,85 and 84 $(800-1300 \mathrm{~m})$ are dominated by Picea and Corylus. In the samples 72, 71.3, 69 and 65, collected further from the Black Sea, from 1600-2100 m, NAP increases again to 45-73\%. The main NAP taxa are Poaceae, Artemisia, Matricaria-type, Cerealia-type and Plantago 
lanceolata-type, whereas AP are represented by Pinus diploxylon-type and Quercus roburtype. The last sample $62(1416 \mathrm{~m})$ is dominated by Quercus robur-type.

The pollen spectra of transect III are dominated by Pinus diploxylon-type (18-61\%). The closest samples to the Black Sea, 143 and 140 (250-400 m), are dominated by Alnus, Carpinus betulus, Ostrya-type, Corylus with Castanea, Fagus, Tilia, Ulmus/Zelkova and Hedera helix. NAP is presented by Xanthum spinosum-type, Poaceae and Chenopodiaceae. The next samples, 137, 122, 134, 133, and 132 (250-1000 m), are dominated by Ostrya-type, Quercus robur-type, Carpinus betulus, Juniperus, Picea and Abies. In the samples 127, 126 and 124 (2000-2400 m), the role of NAP increases with altitude up to $36 \%$, mainly consisting of Poaceae and Plantago lanceolata-type. The AP is presented by conifer pollen Pinus diploxylon-type, Picea and Abies.

The pollen spectrum of the top of core 22-GC3 is dominated by AP (64\%) with highest values of Pinus diploxylon-type (26\%), Quercus robur-type (8.5\%), Juniperus (8\%), Alnus (4.5\%), Fagus (4\%), Corylus (2.5\%). NAP is presented mainly by Chenopodiaceae (12\%), Artemisia (6\%), Poaceae (6\%), and Xanthium spinosum-type (4\%).

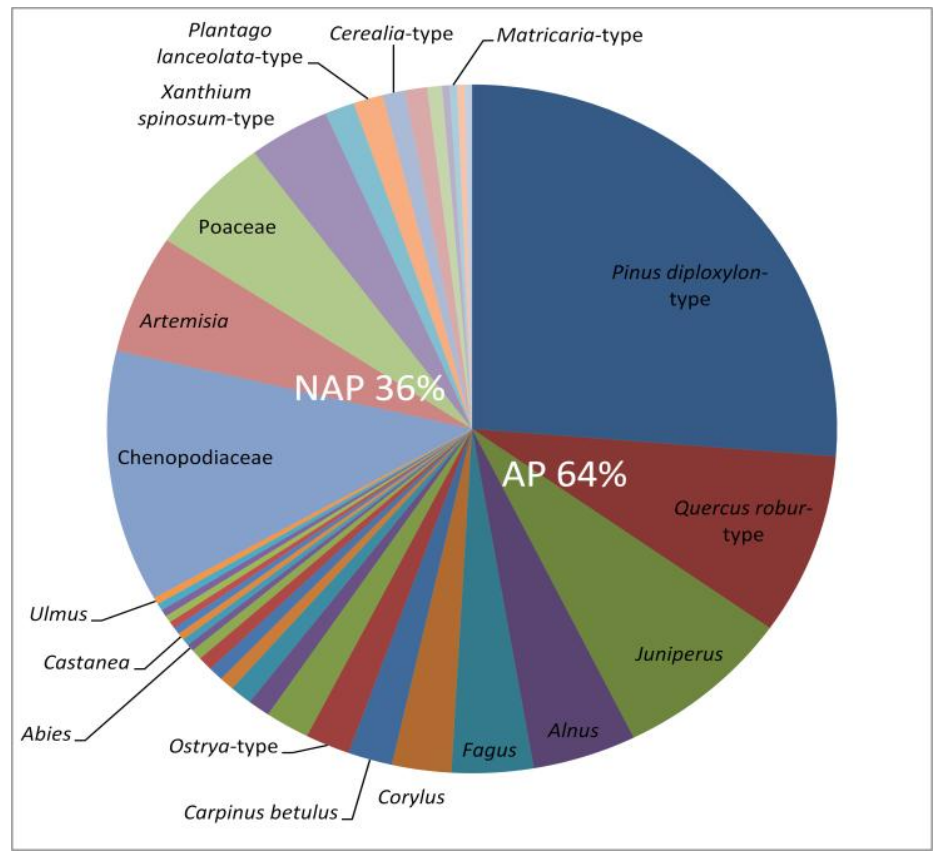

Fig. 4. Pollen spectra of the top of core 22-GC3.

\section{Interpretation and discussion}

The palynological studies on 31 surface samples from Northern Anatolia, collected in the year 2011, reveal considerable geographical differences in pollen spectra of the studied transects. The pollen diagram (Fig. 3) and pollen maps (Fig. 5) demonstrate that higher Fagus 
percentages are characteristic for transect I, where the mountains are not higher than $1500 \mathrm{~m}$ and modern vegetation dominated by oriental beech forests, where firs or spruces do not grow (Zohary, 1973; Mayer and Aksoy, 1986). Picea show high values near the Black Sea in transects II and III (Figs. 3 and 5), within the distribution area of Picea orientalis (Mayer and Aksoy, 1986). Further south, in dryer and more continental regions of Anatolia, Quercus robur and Pinus diploxylon-type dominate in all three transects. In the dry forest-steppe and steppe central regions, Poaceae and Artemisia are typical (Figs. 3 and 5). Thus, open vegetation occurs at altitudes higher than $1500 \mathrm{~m}$. Xanthium spinosum-type and Chenopodiaceae occur more often in coastal areas (Figs. 3 and 5), and possibly stem from salt marshes on the Black Sea coast. Pinus diploxylon-type is a dominant taxa in transects I and III.
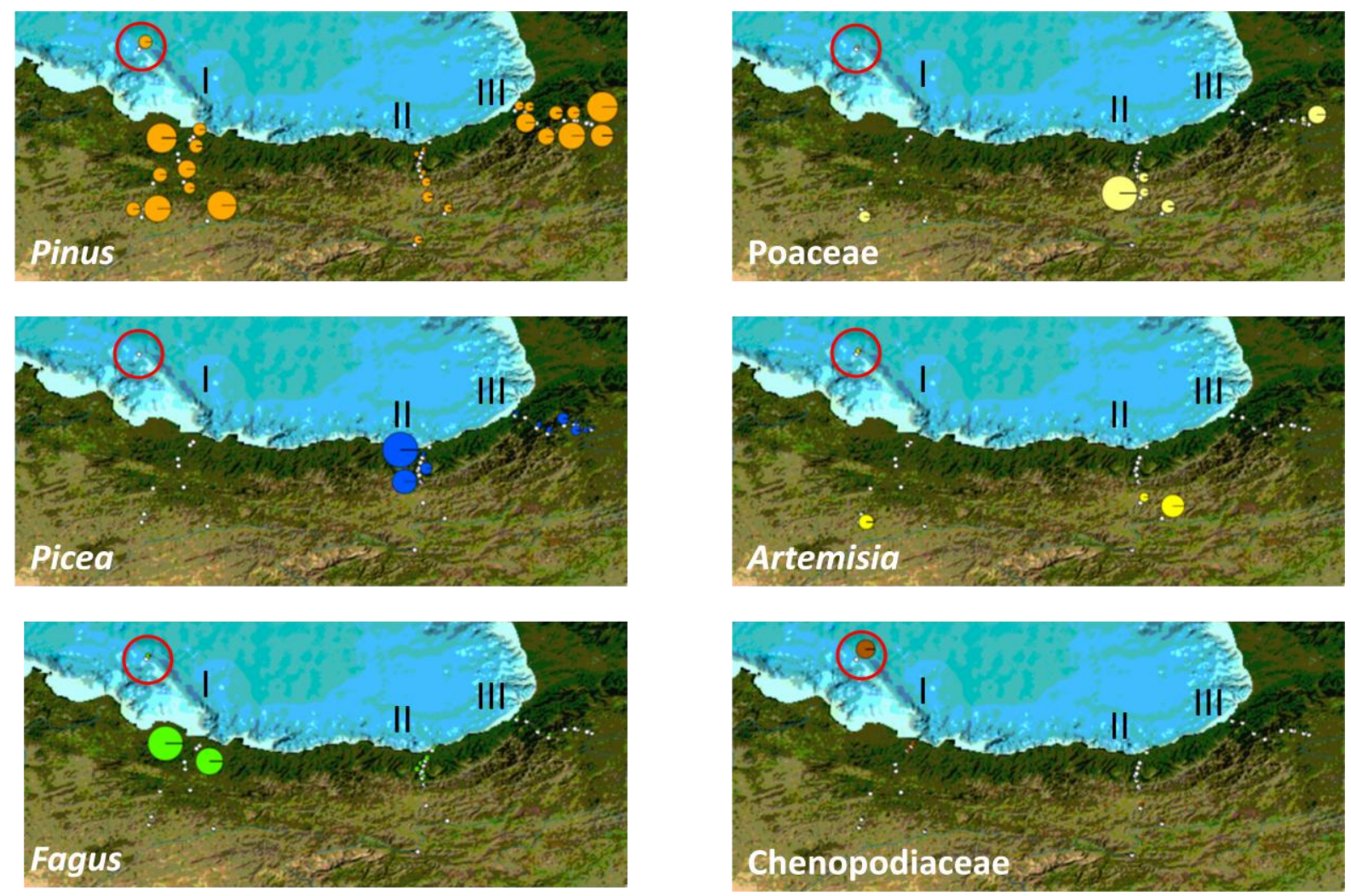

Fig. 5. Pollen maps for selected taxa. The size of the circle represents the $\%$.

Pollen spectra of the top core (Fig. 4) is more similar to pollen spectra from the nearest transect I than to eastern transects II and III, where Picea plays a big role in pollen spectra (Fig. 5). Comparing surface samples from the core 22-GC3 with surface samples from land, we conclude that the main pollen source area for the core include the coastal areas and northern slopes of the Pontic Mountains near transect I. This conclusion is similar to the results of a study by Shatilova (1974), who analyzed pollen-spore distribution in the modern 
sediments of a $120 \mathrm{~km}$ off-shore zone along the Georgian Black Sea coast. She demonstrated that pollen complexes of modern marine sediments from the north and south Colchid Lowlands are very similar and reflect very well the general character of flora and the main vegetation types like wet Alnus dominated forest, mixed deciduous forests, Fagus forests and coniferous Picea-Abies forests.

\section{Conclusions and perspectives}

Preliminary results of the palynological study on surface samples from Northern Anatolia reveal that pollen distribution reflects vegetation patterns of the area, which are controlled by climate and topography. The comparison of the top sample from the Black Sea core 22-GC3 with surface samples on land suggests the nearest coastal areas and northern slopes of the Pontic Mountains as the main pollen source area.

The further course of this investigation will include in the analysis of further samples in each transect up to a total of 20 , as well as studying the two additional western transects. In order to define the main source area for core 22-GC3, pollen spectra of surface samples and the top core will be analysed by using multivariate statistics such as a principal component analysis. Combining pollen data from surface samples with climate data will provide the best opportunity to use the transfer functions based on modern analogues for the reconstruction of climate parameters such as annual temperature and precipitation for pollen record 22-GC3 during the Eemian, the Holocene and the last glacial period.

\section{Acknowledgments}

We thank Laura Sutcliffe for polishing the English. The field work of the first author was financially supported by Deutsche Forschungsgemeinschaft (DFG) within the SPP 1266 "INTERDYNAMIC".

\section{References}

Cross, A.T., Thompson, G.G., Zaitzeff, J.B., 1966. Source and distribution of palynomorphs in bottom sediments, southern part of Gulf of California. Marine Geology 4, 467-524.

Groot, J.J., 1966. Some observations on pollen grains in suspension in the estuary of the Delaware river. Marine Geology 4, 409-416.

Groot, J.J., Groot, C.R., 1966. Marine palynology: possibilities, limitations, problems. Marine Geology 4, 387-395. 
Herzschuh, U., Kürschner, H., Battarbee, R., Holmes, J., 2005. Desert plant pollen production and a 160-year record of vegetation and climate change on the Alashan Plateau, NW China. Vegetation History and Archaeobotany 15, 181-190.

Hicks, S., 2007. Surface Samples and Trapping. In: Editor-in-Chief: Scott A. Elias (ed). Encyclopedia of Quaternary Science. Elsevier, Oxford, pp. 2529-2535.

Hooghiemstra, H., Lézine, A.-M., Leroy, S.A.G., Dupont, L., Marret, F., 2006. Late Quaternary palynology in marine sediments: A synthesis of the understanding of pollen distribution patterns in the NW African setting. Quaternary International 148, 29-44.

Juggins, S., 2003. C2 User Guide. Software for Ecological and Palaeoecological Data Analysis and Visualisation. University of Newcastle, Newcastle upon Tyne.

Koreneva, E.V., 1966. Marine palynological researches in the U.S.S.R. Marine Geology 4, 565-574.

Mayer, H., Aksoy, H., 1986. Wälder der Türkei. Gustav Fischer Verlag, Stuttgart-New York (in German).

Shatilova, I.I., 1974. Palinologicheskoe obosnovanie geokhronologii verhnego Pliotsena i Pleistotsena zapadnoy Gruzii. Metsniereba, Tbilisi.

Shumilovskikh, L.S., Tarasov, P., Arz, H.W., Fleitmann, D., Marret, F., Nowaczyk, N., Plessen, B., Schlütz, F., Behling, H., 2012. Vegetation and environmental dynamics in the southern Black Sea region since $18 \mathrm{kyr}$ BP from the marine core $22 \mathrm{GC} 3$. Palaeogeography, Palaeoclimatology, Palaeoecology 337-338, 177-193.

Shumilovskikh, L.S., Arz, H.W., Fleitmann, D., Marret, F., Nowaczyk, N., Tarasov, P., Wegwerth, A., Behling, H., submitted. Vegetation and environmental changes in Northern Anatolia during the penultimate deglaciation and Eemian recorded in the Black Sea sediments. Quaternary Research, submitted.

Stanley, E.A., 1965. Abundance of pollen and spores in marine sediments off the eastern coast of the United States. Southeastern Geology 7, 25-33.

Traverse, A., Ginsburg, R.N., 1966. Palynology of the surface sediments of Great Bahama bank, as related to water movement and sedimentation. Marine Geology 4, 417-459.

Zagwijn, W.H., Veenstra, H.J., 1966. A pollen-analytical study of cores from the outer silver pit, North Sea. Marine Geology 4, 539-551.

Zohary, M., 1973. Geobotanical foundations of the Middle East. Fischer, Stuttgart, Amsterdam. 


\section{SYNTHESIS}

The multidisciplinary project "Dynamics of Mid-latitude/Mediterranean climate in Northern Anatolia/Black Sea region during the last $150 \mathrm{kyr}$ " was established in order to improve understanding of environmental and climatic dynamics in the Eastern Mediterranean region during the last $134 \mathrm{ka} \mathrm{BP}$ (kilo years before present; ages are presented as calendar years). The present thesis shows the results of palynological studies as part of this wider project, carried out on marine cores 22-GC3, 22-GC8 and 25-GC5 from the Black Sea.

\section{Vegetation changes in Northern Anatolia during the last $134 \mathrm{ka} \mathrm{BP}$}

Preliminary results of the palynological study on surface samples from Northern Anatolia reveal that pollen distribution reflects contemporary vegetation patterns of the area, which are controlled by climate and topography. The comparison of the top sample from the Black Sea core 22-GC3 with surface samples from Northern Anatolia suggests that the nearest coastal areas and northern slopes of the Pontic Mountains is the main pollen source area for the studied marine cores. Therefore, reconstructions of vegetation and climate changes in Northern Anatolia during the last $134 \mathrm{ka}$ BP, obtained from pollen records 22-GC3, 22-GC8 and 25-GC5, correspond to this area.

Vegetation changes in Northern Anatolia during 134-119 ka BP are reconstructed based on pollen records 22-GC3 and 22-GC8. The dominance of open steppe landscapes with pine stands indicates a rather arid climate during 134-131.7 ka BP. During the period of the meltwater signal (131.7-130.4 ka BP), indicated by a depleted ostracod-based $\delta^{18} \mathrm{O}$ record of core 22-GC8, the spreading of steppe vegetation suggests more arid conditions than the previous period. Since $\sim 130.5 \mathrm{ka}$ BP, the spread of oaks in Northern Anatolia indicates warmer/wetter conditions. The onset of the Eemian interglacial period is indicated by the increase of arboreal pollen at $\sim 128.7 \mathrm{ka} \mathrm{BP}$. The Eemian vegetation succession occurs in four phases, corresponding to the main climatic phases in Europe: i) the Quercus-Juniperus phase (128.7$126.4 \mathrm{ka}$ BP) indicates a dry continental climate; ii) the Ostrya-Corylus-Quercus-Carpinus phase (126.4-122.9 ka BP) suggests warm summers, mild winters, and high year-round precipitation; iii) the Fagus-Carpinus phase (122.9-119.5 ka BP) indicates cooling and high precipitation; iv) increasing Pinus at $\sim 121-119.5 \mathrm{ka}$ BP marks the onset of cooler/drier conditions. Generally, pollen reconstructions suggest altitudinal/longitudinal migrations of vegetation belts in Northern Anatolia during the Eemian caused by an increased transport of moisture. In contrast with the European records, the pollen record from core 22-GC3/8 reveals the wide distribution of Fagus in Northern Anatolia. This is possibly related to genetic 
factors, as Northern Anatolian beech forests are formed by Fagus orientalis and were wide spread around the Black Sea during the last interglacial. Central European forests, however, contain another (sub)species Fagus sylvatica, which was less competitive during the Eemian and never dominant in Europe. Furthermore, the suggested increased transport of moisture towards inner Anatolia led to longitudinal and altitudinal migrations and the wide distribution of Fagus in Pontic Mountains.

Long-term vegetation changes during the last glacial (64-25 ka BP), obtained from pollen record from core 25-GC1, suggest a decrease in temperatures towards $25 \mathrm{ka} \mathrm{BP}$, indicated by the decreasing role of Quercus and increasing role of Pinus. The presence of temperate and Mediterranean species such as Fagus, Carpinus betulus, Ostrya, and Phillyrea suggest the presence of glacial refugia of these trees in Northern Anatolia. A low contribution of arboreal pollen between 64-60 ka BP suggests that this period was apparently more arid than 27-25 ka BP. The pollen record 25-GC1 reflects a sensitive reaction of the vegetation of Northern Anatolia to abrupt climate changes during alternating warm and cold intervals, known from ice-core records as Dansgaard-Oeschger (D-O) events. D-O interstadials are characterised by a spreading of temperate forests and especially of Quercus. Thereby, the maximum of Quercus in the most pronounced interstadials 14 and 12 occurs $~ 500$ years later after the onset of warming. D-O stadials are characterized by a spread of xerophytic vegetation in Northern Anatolia, indicating cold climatic conditions. The impact of cold Heinrich events (HE) and D-O stadials on vegetation are similar.

The pollen record from core 22-GC3 was used for the reconstruction of vegetation changes in Northern Anatolia during the last $18 \mathrm{ka}$. The presence of steppe suggests cold/dry conditions during 18-14.7 ka BP. The Pinus-Quercus forest developments during 14.7-12.9 ka BP suggest warmer/wetter environments. The Younger Dryas cool period (12.9-11.7 ka BP) is reflected by the spread of steppe in Northern Anatolia. The onset of the Holocene interglacial is indicated by forest development at $\sim 11.7 \mathrm{ka}$ BP. The Holocene vegetation development reveals four main phases: i) the Artemisia-Quercus-Pinus phase (11.7-8.5 ka BP) suggests relatively dry conditions; ii) the Pinus-Quercus-Fagus-Alnus-Corylus phase (8.5-5 ka BP) indicates warm and wet conditions; iii) the Pinus-Quercus-Alnus-Corylus-Artemisia phase (5$1.6 \mathrm{ka} \mathrm{BP})$ reflects cooler/drier conditions and/or increased anthropogenic activity; iv) the Pinus-Quercus-Alnus-Artemisia phase (1.6-0 ka BP) with Ostrya-type, Juglans, Platanus, Plantago lanceolata marks an increased anthropogenic activity.

In general, the vegetation changes in Northern Anatolia during the last 134 ka correlate well with European evidence and are explained by the global temperature changes and by 
changes in longitude of the westerlies. This suggests that the climate of the Atlantic region governed the climatic situation in Northern Anatolia/Black Sea region during the last $134 \mathrm{ka}$.

\section{Changes in sea-surface conditions of the Black Sea during the last $134 \mathrm{ka} \mathrm{BP}$}

The additional study on organic-walled dinoflagellate cysts (dinocysts) from the cores 22-GC3, 22-GC8 and 25-GC5 provided the possibility to reconstruct sea-surface conditions during the last $134 \mathrm{ka} \mathrm{BP}$. This dinocyst record from the Black Sea is the first for the Eemian.

The dinocyst records 22-GC3/8 were used for the reconstruction sea-surface conditions during 134-119 ka BP. During 134-128 ka BP, dinocysts, presented by Pyxidinopsis psilata, Spinifirites cruciformis and Caspidinium rugosum, indicates freshwater/brackish sea-surface conditions in the Black Sea. Dinocysts together with ice-rafted detritus (IRD) records reveal climatic instability during the penultimate deglaciation (134-130.4 ka BP), characterised by alterations of short-lived cold and warm events. After $\sim 130.4 \mathrm{ka} \mathrm{BP}$, dinocyst concentration increased, indicating enhanced primary productivity and warmer conditions. At 128 ka BP, freshwater/brackish species changed to marine assemblages (Lignulodinium machaerophorum, Spiniferites pachydermus, S. mirabilis, Bitectatodinium tepikiense, Tectatodinium pellitum, Nematosphaeropsis labyrinthus etc.). This change clearly reflects an establishment of marine conditions in the Black Sea, which occurred through the increase in the global sea-level and inflow of warm and saline Mediterranean water into the Black Sea basin through the Bosphorus. The Eemian assemblages are characterised by the presence of several fully marine species such as Spiniferites pachydermus, Spiniferites mirabilis, Bitectatodinium tepikiense, Tectatodinium pellitum, Nematosphaeropsis labyrinthus, indicating higher than present ( 18) sea surface salinity (SSS) of $\sim 28-30$ at $\sim 126.5-121 \mathrm{ka} \mathrm{BP}$. An elevated Mediterranean inflow triggered by a higher global sea-level and higher temperatures at the beginning of the Eemian are likely to be the mechanism for such high SSS. Between 127.6-125.3 ka BP, dinocyst assemblages are dominated by Tuberculodinium vancampoae and Spiniferites pachydermus and reveal relatively high sea-surface temperature (SST) $\left(7-12^{\circ}\right.$ in winter and $27-29^{\circ}$ in summer) in the Black Sea, suggesting high temperatures

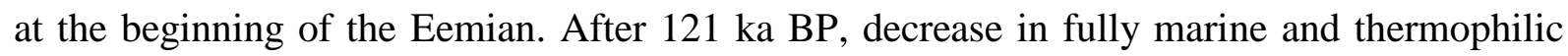
species suggest a reduction in SSS and SST of the Black Sea, possibly due to lower Mediterranean inflow.

The dinocyst record 25-GC1 provides information about sea-surface conditions in the Black Sea between 64-25 ka BP. The dinocyst assemblages are dominated by Pyxidinopsis psilata and Spiniferites cruciformis, indicating freshwater/brackish conditions during the last 
glacial. The increase in concentrations of freshwater algae (Pediastrum, Botryococcus) and decrease in concentrations of marine dinocysts (e.g. Lingulodinium machaerophorum, Operculodinium centrocarpum) and acritarchs (e.g. Cymatiosphaera) suggest a lowering of the Black Sea surface salinity towards MIS 2. D-O interstadials are characterised by increased concentrations of freshwater/brackish dinocysts such as Pyxidinopsis psilata and Spiniferites cruciformis, indicating enhanced primary productivity in the Black Sea. In contrast, D-O stadials show low dinocyst concentrations indicative for reduced primary productivity.

Sea-surface conditions of the Black Sea during 18-0 ka BP were reconstructed based on the dinocyst record 22-GC3. Between 18-14.7 ka BP, dinocysts, represented by Pyxidinopsis psilata and Spiniferites cruciformis, were present at low concentrations, indicating reduced primary productivity and low temperatures. At $\sim 14.7-12.9 \mathrm{ka} \mathrm{BP}$, an increase in dinocyst concentrations reflects an increase in primary productivity of the Black Sea and warmer conditions. The Younger Dryas cooling (12.9-11.7 ka BP) is characterised by low dinocyst concentrations. The onset of the Holocene is indicated by the increase primary productivity at $\sim 11.7 \mathrm{ka} \mathrm{BP}$. At $\sim 8.3 \mathrm{ka} \mathrm{BP}$, freshwater/brackish assemblages disappear and marine species such as Lingulodinium machaerophorum and Spiniferites ramosus-group enter and spread in the Black Sea. The dinocyst record 22-GC3 demonstrates that SSS between 8.3-0 ka BP never exceeded $\sim 18-20$, and reveal freshening of the sea-surface at $\sim 2.5-3 \mathrm{ka} \mathrm{BP}$. Changes in nutrient supply, in addition to changes in SSS and SST, are likely to have played a significant role in the successions of dinocyst assemblages during the Eemian and the Holocene.

In summary, the primary factors explaining changes in sea-surface conditions of the Black Sea during the last $134 \mathrm{ka} \mathrm{BP}$ are the temperature, influencing the primary productivity, and the global sea-level, the increase of which led to the Mediterranean inflow into the basin through the Bosphorus and the change in the hydrology of the Black Sea.

Climatic conditions in Northern Anatolia/Black Sea region during the Eemian in comparison to the Holocene

In general, pollen and dinocyst records obtained from the Black Sea cores 22-GC3, 22GC8 and 25-GC1 correlate well with northern hemispheric climatic evidence that the Eemian was warmer than the Holocene. The Eemian forests in Northern Anatolia were dominated by temperate and sub-Mediterranean species, suggesting rather warm summers and winters without frost. In contrast, the Holocene vegetation was dominated by temperate species and pine trees, reflecting generally cooler/drier conditions. The dominance of fully marine dinocysts reveals higher SSS in the Black Sea during the Eemian in comparison to the 
Holocene, explained by higher global and Mediterranean sea-levels and therefore increased Mediterranean inflow into the Black Sea basin. Presence of tropical/subtropical species reflects higher SST in the Eemian than in the Holocene.

By considering the Eemian interglacial as a possible analogue for future climatic conditions and based on our data, the present rising of the global sea-level should lead to an elevated Mediterranean inflow into the Black Sea basin, increasing its salinity. This would open the way for the spreading of Mediterranean species and, therefore, change the biota of the Black Sea. Those changes could have economic consequences and should be taken into account. The global climate warming would lead to higher annual temperatures in Northern Anatolia, but without drought periods. This is an important point for the future agricultural and forestry development of Turkey. However, the prognoses based on the Eemian research should be used very carefully, because, in contrast to the present warming, the Eemian warmer climate was driven by high summer insolation and had a possibly different atmospheric circulation to today.

\section{Environmental reactions of Northern Anatolia/Black Sea region to the abrupt changes}

One highly important finding of this study is the synchrony of vegetation and seasurface reactions to the abrupt climate changes. Vegetation reactions to warming are clearly indicated by the spread of pine and oak forests, whereas cooling is characterised by development of steppe. The primary productivity in the Black Sea increased during warm and decreased during cold intervals. The records reveal a synchronous start of vegetation and seasurface reactions to the onset of the glacial warming. However, forest developments reach their maxima several hundred years later after the start of warming, indicating vegetation development during this interval as a response to increased temperature/precipitation. High temperatures at the beginning of the interglacial triggered changes in atmospheric circulation, such as a northward migration of the summer position of the westerlies, which apparently continued for several hundred years and caused "lags" in terrestrial responses. This is an important finding, considering modern global warming. On the one hand, the immediate reaction of the vegetation in Northern Anatolia to the warming demonstrates the sensitivity of the plant communities to temperature changes. On the other hand, "lags" of responses demonstrate the relative stability of ecosystems and their continuous and gradual reaction to the rapid climate change. We suggest monitoring of the natural vegetation in Turkey as an important tool for understanding the development of the regional climatic changes and informing future predictions. 


\section{PERSPECTIVES}

The present thesis reveals high sensitivity of the Northern Anatolian/Black Sea region to climate variations during the last $134 \mathrm{ka} \mathrm{BP}$, and highlights the potential of the region for further palaeoclimatic investigations. There is a need for new cores from the Black Sea covering the interval between 120-60 ka BP, which would provide information about vegetation and hydrological changes during the interglacial-glacial transition as well as transformation of the basin from marine into freshwater/brackish environment. Additional long cores from Eastern Mediterranean (e.g. Black Sea, Marmara Sea, Aegean Sea, Anatolian lakes) would provide an opportunity for geographical correlations of changes in vegetation and sea-surface conditions in the region through time. Moreover, the knowledge about Northern Anatolian vegetation and Black Sea sea-surface dynamics in the Eemian should be used for evaluation of the regional models dealing with Eemian and Holocene climate and of the prognostic models. To better understand changes in the past, studies on modern pollen rain and dinoflagellates are necessary. The pollen source area for the Black Sea cores still needs to be studied in more detail in the regions around the Black Sea. An unknown contribution of the local and regional vegetation to the pollen spectra from the Black Sea is one source of uncertainty for the vegetation reconstructions. Further studies on surface samples from Anatolia and the Black Sea would improve our understanding of pollen distribution on land and in the sea as well as pollen transport in the Black Sea and dependence of pollen source area on distance from coast. Furthermore, combining pollen data from surface samples from Northern Anatoliawith climate data will provide the best opportunity to use the transfer functions based on modern analogues for the reconstruction of climate parameters such as annual temperature and precipitation for the pollen record 22-GC3 during the Eemian, the Holocene and the last glacial period. The same method could be used for geographical correlations of the existing pollen records from Anatolia and their correlations with records from the Western Mediterranean region. Critical comparison of pollen-based reconstructions with reconstructions based on other proxies allows sources of uncertainty in the methods to be detected. In order to achieve more detailed information on sea-surface conditions of the Black Sea during the glacial, laboratory studies on the dominant dinocyst species Pyxidinopsis psilata and Spiniferites cruciformis are required. Thereby, important questions to be addressed include the evaluation of salinity and temperature limits of dinocysts for cyst formations, as well as the morphological differences of cysts along salinity and temperature gradients. 


\section{ACKNOWLEDGEMENTS}

Завершая работу над диссертацией, прежде всего мне хотелось бы поблагодарить моих родителей Алевтину Анатольевну и Сергея Евгеньевича, сестер Настю и Лену и всех родных, отпустивших меня в дальние края за знаниями и поддерживающих во всех моих начинаниях. Именно с вашей незримой помощью я довожу начатое до конца. Благодарю моих школьных и университетских преподавателей за полученные знания, и особенно Сергея Леонидовича Есюнина, научившего меня думать и не останавливаться на достигнутом. И конечно, огромное спасибо моим друзьям за смех и радость.

I would like to express my sincere thanks to my super-visors: Hermann Behling, who gave me so much freedom in my research and continuously supported my scientific activities especially in networking and field research, and Erwin Bergmeier, for his support and fruitful botanical discussions. Also I am grateful to Frank Schlütz, who opened up the microscopic universe and its connection to the past for me, and to Fabienne Marret, who introduced me to the exciting world of dinoflagellates. I thank Helge Arz for kindly providing his cores for palynological investigations, establishing the age-depth models and vigorous exchange of ideas. Many thanks go to Dominik Fleitmann for sharing data and efficient discussions about isotopes and to Pavel Tarasov for his humorous teaching of numerical methods of vegetation reconstructions. Norbert Nowaczyk, Birgit Plessen, Olga Kwiecien and Antje Wegwerth all kindly shared their data with me for multi-proxy comparisons. My acknowledgements are to Kenneth N. Mertens, Vera Pospelova, Petra Mudie, Hans-Jürgen Beug, Eberhard Grüger, Mariana Filipova-Marinova, Eliso Kvavadze, Galina Pashkevich, Maria Dergacheva, and Tatyana Pinchuk provided many productive discussions and important publications. To all these people I am very grateful. Special thanks also go to Laura Sutcliffe for her thorough English corrections.

It gives me immense pleasure to acknowledge Ursula Grothmann and Uta Nüsse-Hahne, who tireless helped with laboratory needs, Astrid Rodriguez and Elke Braunschweig for support in paper-warfare, as well as my colleagues and friends from the department for the kind atmosphere in our daily routine, especially Inke Achterberg and Magdalena Plath, sharing with me not only the room but also my problems and happiness. Many thanks to HiWi students especially to Selina André and Denise Hartken, helping with reference collections. I am grateful to Jens Schneeweiß for keeping my mind open for challenges in geoarcheology, to Hubertus Leuschner, Frank Schlütz and Thomas Giesecke for opportunities to do palynological research in other parts of Eurasia outside of the Black Sea, to the friends 
from the Seminar for Turcology, who taught me the Turcic way of thinking, to Tatyana Pinchuk, who practically introduced me to the Black Sea geology.

I thank my family and all my numerous friends and colleagues from all over the world for giving me energy to keep going on. My deepest gratitude goes to my partner for his infinite patience with me and supporting in all my crazy ideas.

It was a pleasure to work with all you! You were always here whenever I needed you!

This work was financially supported by the Deutsche Forschungsgemeinschaft (BE 2116/20-1, BE 2116/20-2) within the SPP 1266 "INTERDYNAMIC". I would particulary like to express my thanks to the appreciate coordinators of the priority program INTERDYNAMIC Michael Schulz and André Paul, as well as organizers of INQUA-2011, COMPARE-2012 and PAGES-2013 for their financial support of my participation in the international meetings. 
APPENDIX 1. Complete pollen diagram (\%) of the upper part of the core 22-GC3, covering the last $18 \mathrm{ka}$. 
APPENDIX 2. Complete pollen diagram (\%) of the cores $22-\mathrm{GC} 3 / 8$, covering the penultimate deglaciation and the Eemian during 134-119 ka BP. 
Appendix 2 
APPENDIX 3. Complete pollen diagram (\%) of the core 25-GC1, covering the last glacial period during 64-25 ka BP. 
Appendix 3 
APPENDIX 4. Complete pollen diagram (\%) for surface samples, collected in Northern Anatolia in 2011. 
Appendix 4 


\section{CURRICULUM VITAE}

\section{PERSONAL DATA}

Full name: Lyudmila Shumilovskikh

Born on: $\quad$ 16.01.1982

Born in: Kukushtan, Permskaya oblast', Russia

Nationality: Russian

\section{PROFESSIONAL EXPERIENCE}

2013 - present palynological studies within the scope of the DFG project "Dendroökologische Untersuchungen subfossiler Moor-Kiefernwälder in Niedersachsen"

2009-2012 palynological studies within the scope of the DFG project "Dynamics of Midlatitude/Mediterranean climate during the last 150 ka: Black Sea/Northern Anatolian Paleoenvironmental Reconstructions"

2011-2012 palynological studies on surface samples from Nepal within the scope of the DFG project "Paleoecology of Himalaya during late Quaternary: climate dynamic, vegetation history and anthropogenic influence based on palynological studies on geoarchives from central Nepal"

2008 -2009 palynological studies on:

- peat/mire deposits at Venner Moor in Germany within the scope of the DFG project "Dendroökologische Üntersuchungen subfossiler Moor-Kiefernwälder",

- surface samples and core from Donggi Cona Lake (Tibet) within the scope of the DFG project "Landscape and Lake-System Response to Late Quaternary Monsoon Dynamics on the Tibetan Plateau - Northern Transect",

- two cores from Gobi-Altai and Orkhon Valley (Mongolia) within the scope of the DFG-project "Late Pleistocene, Holocene and ongoing geomorphodynamics in the Gobi Desert, South Mongolia"

$2000-2005$ student/scientific assistant at the Department of Zoology of Invertebrate Animals in University of Perm (Russia)

\section{EDUCATION}

2009 - present PhD student at the Department of Palynology and Climate Dynamics in University of Göttingen (Germany)

$2007-2009$ MSc in Biodiversity and Ecology at the University of Göttingen (Germany)

Major subject: Vegetation analysis and Vegetation history

Minor subjects: Animal ecology, Soil science

$1999-2004 \quad$ Graduation in Ecology (Diplom) at the University of Perm (Russia)

Subject: Invertabrates animal ecology

1989-1999 Elementary, Middle and High School at Babkinskaya school, Kukushtan (Permskaya oblast', Russia)

\section{$\underline{\text { PUBLICATIONS }}$}

Shumilovskikh, L.S., Arz, H.W., Fleitmann, D., Marret, F., Nowaczyk, N., Tarasov, P., Wegwerth, A., Behling, H. Vegetation and environmental changes in Northern Anatolia during the penultimate deglaciation and Eemian recorded in Black Sea sediments. Quaternary Research, in review. 
Shumilovskikh, L.S., Marret, F., Fleitmann, D., Arz, H.W., Nowaczyk, N., Plessen, B., Behling, H. Eemian and Holocene sea-surface conditions in the southern Black Sea: organic-walled dinoflagellate cyst record from core 22-GC3. Marine Micropaleontology, in review.

Shumilovskikh, L.S., Tarasov, P., Arz, H.W., Fleitmann, D., Marret, F., Nowaczyk, N., Plessen, B., Schlütz, F., Behling, H., 2012. Vegetation and environmental dynamics in the southern Black Sea region since $18 \mathrm{kyr}$ BP derived from the marine core 22-GC3. Palaeogeography, Palaeoclimatology, Palaeoecology 337-338, 177-193.

Lehmkuhl, F., Hilgers, A., Fries, S., Hülle, D., Schlütz, F., Shumilovskikh, L., Felauer, T., Protze, J., 2011. Holocene geomorphological processes and soil development as indicator for environmental change around Karakorum, Upper Orkhon Valley (Central Mongolia). Catena 87(1), 31-44.

Eckstein, J., Leuschner, H.H., Giesecke, T., Shumilovskikh, L., Bauerochse, A., 2010. Dendroecological investigations at Venner Moor (northwest Germany) document climate-driven woodland dynamics and mire development in the period 2450-2050 BC. The Holocene 20(2), 231244.

Esyunin, S.L., Shumilovskikh, L., 2008. Население герпетобионтных пауков (Aranei) заказника «Предуралье» в Пермской области (The herpetobiont spider (Aranei) assemblages of the „Preduralie“" Reserve in Permskaya Oblast'). Euroasian entomological journal 7(1), 47-56 (in Russian with English abstract).

\section{CONFERENCES, MEETINGS, WORKSHOPS}

Workshop (Palaeo-)ecology of cyst forming dinoflagellates, 17-20 May 2010, Bremen, Germany (talk)

$4^{\text {th }}$ Workshop on Non-Pollen Palynomorphs, 16-19 June 2010, Besançon, France (poster)

INQUA 501"Caspian-Black Sea-Mediterranean corridor during the last $30 \mathrm{ky}$ : sea level change and human adaptive strategies" - IGCP 521 "Black Sea-Mediterranean corridor during the last $30 \mathrm{ky}$ : sea level and human adaptation" Sixth Plenary Meeting, 27 September-5 October 2010, Rhodes, Greece (talk)

INQUA XVIII, 20-28 July 2011, Bern, Switzerland (talk)

$21^{\text {st }}$ Meetings of Arbeitskreis Vegetationsgeschichte, 23-26 September 2011, Augsburg, Germany (talk)

COMPARE 2012 Workshop, 18-22 March 2012, Bremen, Germany (talk)

IPC XIII/IOPC IX, 22-30 August 2012, Tokyo, Japan (talk)

Russian Micropaleontological Meeting, 12-16 September 2012, Gelendzhik, Russia (talk)

$22^{\text {nd }}$ Meetings of Arbeitskreis Vegetationsgeschichte, 28-30 September 2012, Bonn, Germany (talk)

PAGES $2^{\text {nd }}$ Young Scientist Meeting and $4^{\text {th }}$ Open Science Meeting, 11-16 February 2013, Goa, India (poster) 


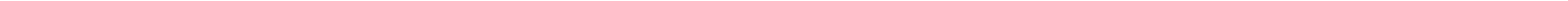




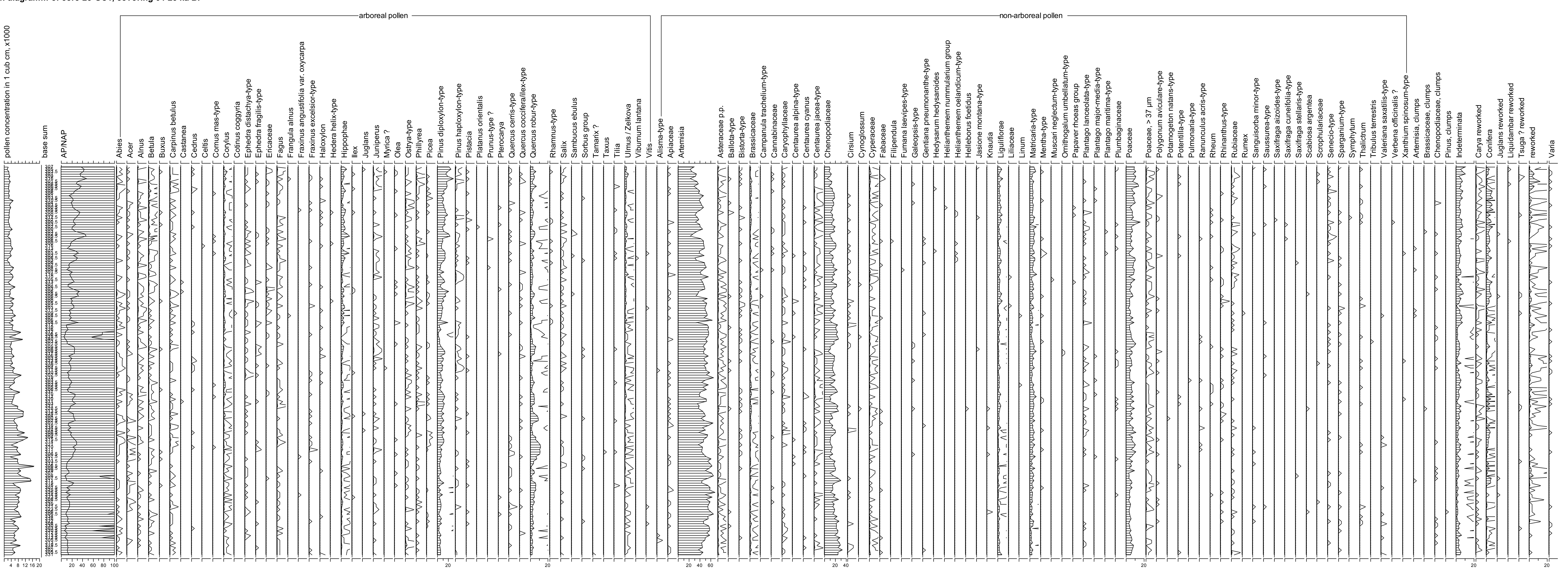




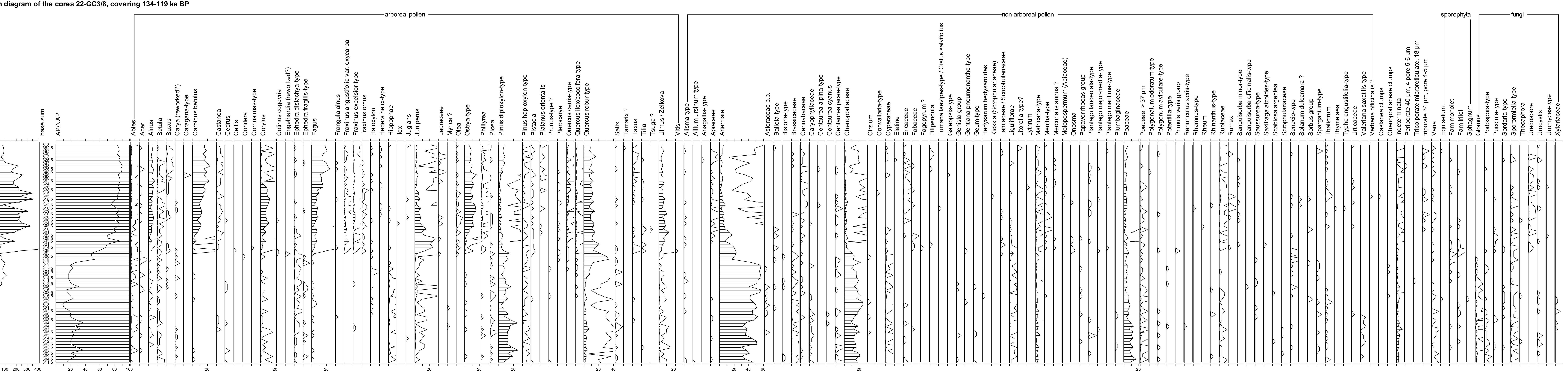




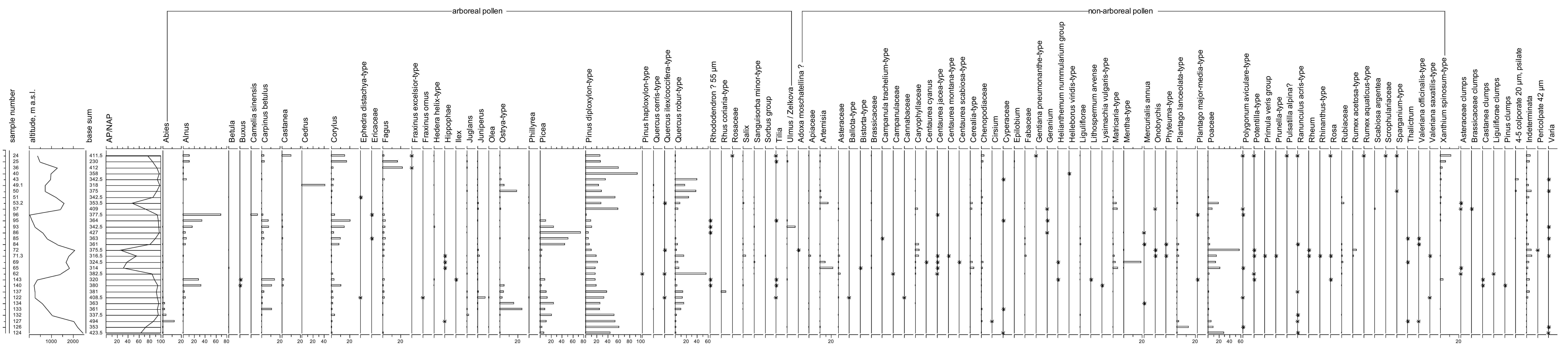

